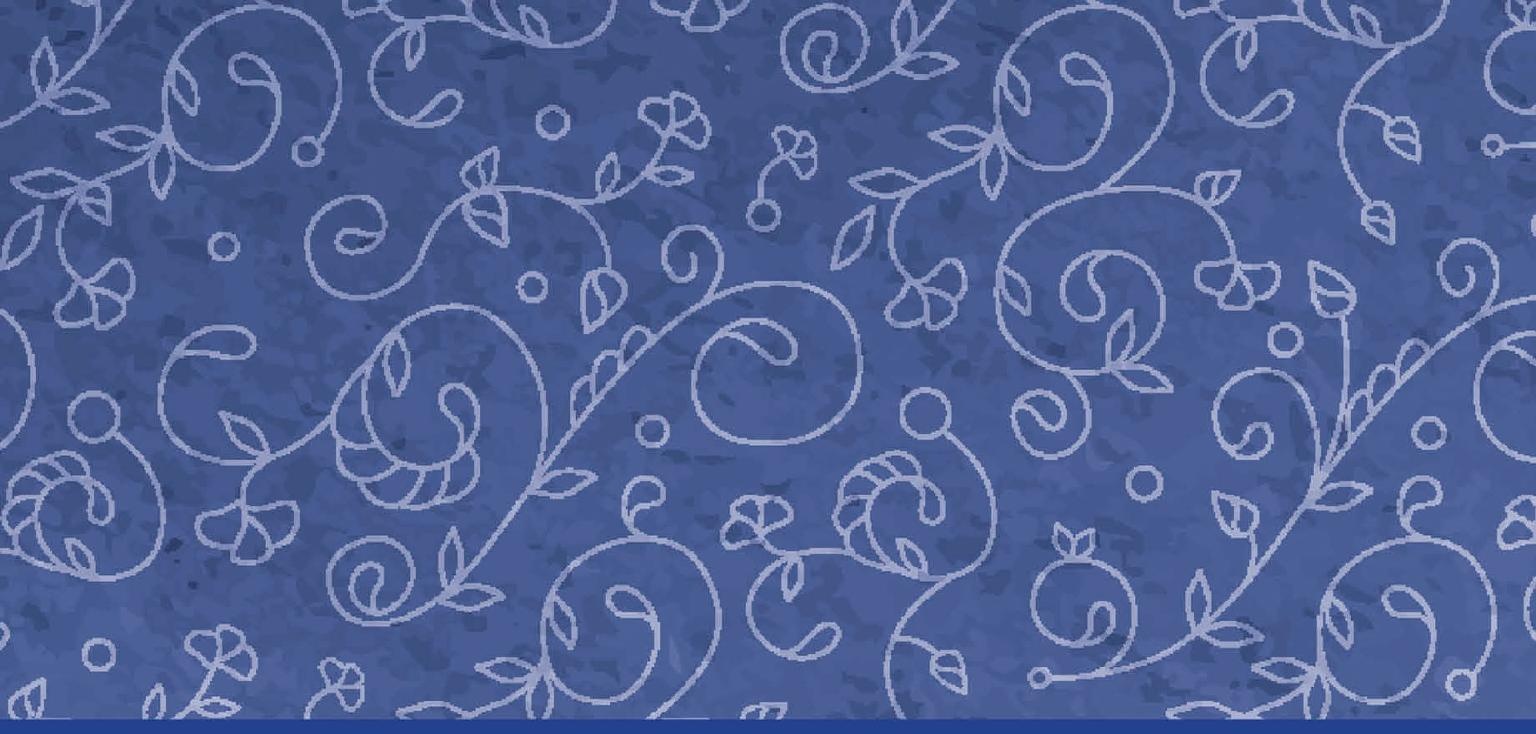

Routledge New Horizons in South Asian Studies

\title{
SUSTAINABLE \\ DEVELOPMENT IN INDIA
}

GROUNDWATER IRRIGATION, ENERGY USE, AND FOOD PRODUCTION

Edited by

Koichi Fujita and Tsukasa Mizushima

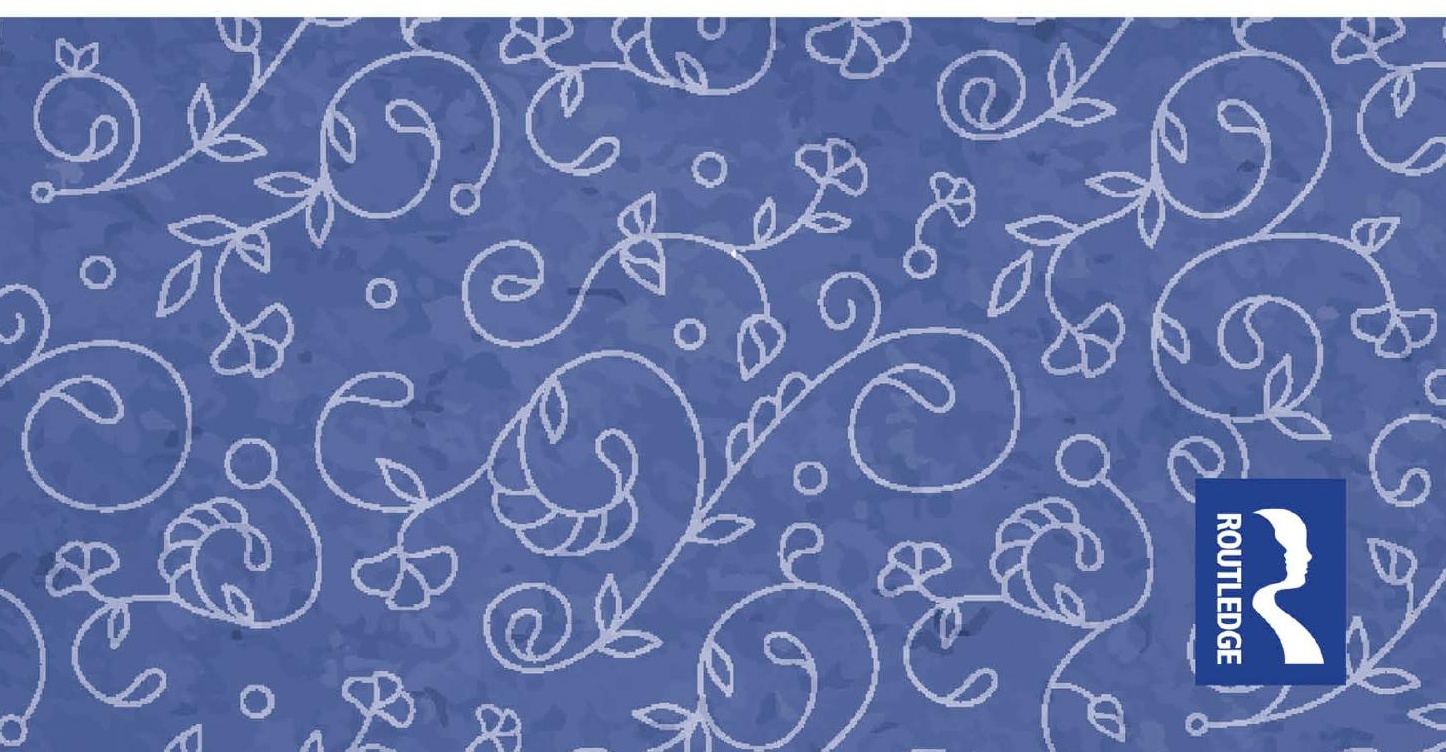




\section{Sustainable Development in India}

This book explores and interrogates the food-water-energy nexus, arguably the most crucial factor in sustaining India's economic development.

The book sheds light on different experiences faced in states across India, including the consequences of electricity tariff reforms and related policies on irrigated agriculture. Part 1 focuses on the historical development of agriculture and social change in India, with special reference to the mode of responses and adaptations in social systems against the inherent low and erratic rainfall and resulting water stress in India during the pre-colonial period. Additionally, it investigates how colonial development destroyed social systems and discusses future development prospects. Part 2 discusses contemporary issues of agriculture and social change in India.

A comprehensive examination of various important issues related to South Asian agricultural development in the past and in the present, this book will be a valuable reference for researchers of Asian development, sustainable development, environmental policy, South Asian Studies and Development Studies.

Koichi Fujita is Professor of Economics at the Center for Southeast Asian Studies at Kyoto University, Japan.

Tsukasa Mizushima is Professor Emeritus at The University of Tokyo, Japan. 


\section{Routledge New Horizons in South Asian Studies}

Series Editors: Crispin Bates, Edinburgh University; Akio Tanabe, Kyoto University; Minoru Mio, National Museum of Ethnology, Japan

Democratic Transformation and the Vernacular Public Arena in India Edited by Taberez Ahmed Neyazi, Akio Tanabe and Shinya Ishizaka

Cities in South Asia

Edited by Crispin Bates and Minoru Mio

Human and International Security in India

Edited by Crispin Bates, Akio Tanabe \& Minoru Mio

Rethinking Social Exclusion in India

Castes, Communities and the State

Edited by Minoru Mio and Abhijit Dasgupta

Modernity and Spirit Worship in India

An Anthropology of the Umwelt

Miho Ishii

\section{Sustainable Development in India}

Groundwater Irrigation, Energy Use, and Food Production

Edited by Koichi Fujita and Tsukasa Mizushima

For a full list of titles please see www.routledge.com/Routledge-New-Hori zons-in-South-Asian-Studies/book-series/RNHSAS 


\section{Sustainable Development in India \\ Groundwater Irrigation, Energy Use, and Food Production}

Edited by Koichi Fujita and Tsukasa Mizushima

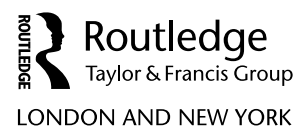


First published 2021

by Routledge

2 Park Square, Milton Park, Abingdon, Oxon OX14 4RN

and by Routledge

52 Vanderbilt Avenue, New York, NY 10017

Routledge is an imprint of the Taylor \& Francis Group, an Informa business

(C) 2021 selection and editorial matter, Koichi Fujita and Tsukasa Mizushima; individual chapters, the contributors

The right of Koichi Fujita and Tsukasa Mizushima to be identified as the authors of the editorial material, and of the authors for their individual chapters, has been asserted in accordance with sections 77 and 78 of the Copyright, Designs and Patents Act 1988.

All rights reserved. No part of this book may be reprinted or reproduced or utilised in any form or by any electronic, mechanical, or other means, now known or hereafter invented, including photocopying and recording, or in any information storage or retrieval system, without permission in writing from the publishers.

Trademark notice: Product or corporate names may be trademarks or registered trademarks, and are used only for identification and explanation without intent to infringe.

British Library Cataloguing-in-Publication Data

A catalogue record for this book is available from the British Library

Library of Congress Cataloging-in-Publication Data

Names: Fujita, Koichi, editor. | Mizushima, Tsukasa, 1952- editor.

Title: Sustainable development in India : groundwater irrigation, energy ]use, and food production / edited by Koichi Fujita and Tsukasa Mizushima.

Description: 1 Edition. | New York : Routledge, 2020. |

Series: Routledge new horizons in South Asian studies | Includes

bibliographical references and index.

Identifiers: LCCN 2020015593 | ISBN 9780367460976 (hardback) |

ISBN 9781003036074 (ebook)

Subjects: LCSH: Irrigation-India. | Groundwater-India. |

Energy policy-India. | Food supply-India. | Social change-India.

Classification: LCC HD1741.I29 S957 2020 | DDC 338.10954-dc23

LC record available at https://lccn.loc.gov/2020015593

ISBN: 978-0-367-46097-6 (hbk)

ISBN: 978-1-003-03607-4 (ebk)

Typeset in Times

by Swales \& Willis, Exeter, Devon, UK 


\section{Contents}

List of figures vii

List of maps ix

List of tables $\quad \mathrm{x}$

List of contributors xii

Preface xvii

1 Introduction 1

KOICHI FUJITA AND TSUKASA MIZUSHIMA

\section{PART I}

Land, water, and population in the past and future

2 Land development and demographic change in Tamil Nadu from the late eighteenth to the early twentieth century TSUKASA MIZUSHIMA

3 From sharing risks to taking risks: the system of entitlements and its fragmentation in eighteenth and nineteenth century Orissa

AKIO TANABE

4 Bengal agrarian society during late colonial rule: the development of the Sundarbans SHINKICHI TANIGUCHI

5 Sustaining tank irrigation in south India through time-tested measures 
vi Contents

6 Ahar: a traditional irrigation system in Southern Bihar TETSUO SATOH

\section{PART II}

Regional path dependencies and policy orientations for sustainability

7 Overview of the food-water-energy nexus in India and South Asia

KOICHI FUJITA AND ATSUSHI FUKUMI

8 Challenges of growth and sustainability: agriculture in Indian Punjab KAMAL VATTA AND PARISHA BUDHIRAJA

9 The nitrogen cycle and fertilizer subsidy in India IPPEI SEKIDO

10 Sustainability of groundwater-irrigated agriculture in India: case studies of Punjab and Tamil Nadu TAKAHIRO SATO

11 Farm power policies and groundwater markets: contrasting Gujarat with West Bengal (1990-2015) TUSHAAR SHAH AND SUJATA DAS CHOWDHURY

Index 


\section{Figures}

1.1 Population and Net Cereals Production and Export in India 8

2.1 Annual Rainfall in Ponneri during 1901-50 21

2.2 Population of Chingleput Compared with Other Districts between 1800 and 1901

2.3 Development of Well Irrigation in the Madras Presidency during the Late Colonial Period $\quad 35$

3.1 Bundles of Palm Leaf Scripts 44

3.2 Examples of Administrative Records (bhiāna: 1776-1777 A.D.) on Palm Leaves 44

4.1 Population Growth of Lower Bengal (1881-1931) 67

5.1 Behavioral Relation between Tanks and Wells in Different Tank Filling Years 91

5.2 Well Density, RF Deviation with Tank area Deviation_South 95

5.3 Well Density, RF Deviation with Tank area Deviation_North 95

6.1 Cross-section of Dikes of Surveyed Ahars 114

6.2 Budhauli Ahar in February (left) and August (middle), 2016 and its Outlet (right) 116

6.3 Biskruwa Ahar in February (left) and August (middle), 2016 and Its Inlet (right) 120

6.4 Dendrogram of Cluster Analysis 122

7.1 Effects of Tariff Policy on Indian Power Sector 132

7.2 T\&D Loss in Major Countries (percentage of output) 133

7.3 Number of Electric Pumpsets in India 136

7.4 Percentage of Agricultural Electricity Subsidy in Gross Fiscal Deficits of State Governments 142

7.5 Unit Cost and Sector-wise Tariff Rate of Electricity Supply 145

7.6 Sector-wise Recovery Rate of Electricity Supply 146

7.7 Commercial Loss and Agricultural Loss in Indian Power Sector 147

8.1 HYV Coverage for Major Food Crops in Punjab 164

8.2 Rice and Wheat Dominance in Punjab Crop Sector 166

8.3 Other Crops in Punjab 167

8.4 Food Production and Productivity Growth: Punjab vs. India 168

8.5 Crop Diversity Index Trends in Punjab 169 


\section{viii Figures}

8.6 Trends in Varietal Diversity Index for Rice and Wheat in Punjab 170

8.7 Groundwater Table in Central Punjab

8.8 Trends in Productivity of Rice and Wheat: Punjab vs. India (1966-2014)

9.1 Fertilizer Subsidy

9.2 Price of Fertilizers (urea, DAP, MOP) 187

$\begin{array}{lll}9.3 \text { Fertilizer Consumption } & 189\end{array}$

$\begin{array}{ll}9.4 \text { Cereal Production } & 189\end{array}$

$\begin{array}{lll}9.5 & \text { Nitrogen Flow Model } & 190\end{array}$

9.6 Nitrogen Cycles in India and China, 2013 191

9.7 Changes in Nitrogen Flow in India: 1961, 1981, 2011

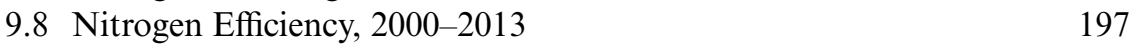

9.9 Total Fertility Rates in Major States of India 198

10.1 Monthly Rainfall and Potential Evapotranspiration (PET) in Ludhiana, Punjab 204

10.2 Inter-temporal Changes in Crop Choice in Ludhiana, Punjab 204

10.3 Geological Stratum and Water Balance in Rice Production in Punjab

10.4 Monthly Rainfall and Potential Evapotranspiration (PET) in Madurai, Tamil Nadu

10.5 Inter-temporal Changes in Crop Choice in Madurai, Tamil Nadu

10.6 Spatial Difference in Crop Choice in Tank Command Area (nanjai)

10.7 Spatial Difference in Crop Choice in Dryland (punjai)

10.8 Geological Stratum and Water Balance in Rice Production in S Village, Tamil Nadu

11.1 Increase in Amon and Boro Paddy Area of 146 Sample Farmers in 5 Survey Villages

11.2 Rising Profile of Pump Owners in Boro Season Land Lease Market

11.3 Increase in Average leased in Land Operated by Water Buyers and Pump Owners

11.4 Pattern of Rise in ToD Power Tariff for farmers in West Bengal

11.5 Average price (Rs./acre) Charged by Submergible Pump Owners for Paddy Irrigation

11.6 Indices of Mean Electricity Price and Irrigation Service Price Levied by Submergible Pump Owners 


\section{Maps}

2.1 Cultivated Land in Chingleput in 1801

2.2 Cultivated Land in Chingleput in 1871

2.3 Composition of Mirasidar and Non-Mirasidar Landholding in Ponneri Villages

2.4 Populations of Hamlets in Chingleput in 1801

2.5 Populations of Hamlets in Chingleput in 1871

2.6 Population Increase by Region, 1881-1911 34

4.1 Bengal in $1901 \quad 69$

4.2 James Rennell's Map of the Delta of the Ganges with the Adjacent Countries (ca.1779) $\quad 71$

5.1 Rainfall Distribution in Tamil Nadu 89

6.1 Location and Inlet-Outlet of Machala Ahar in Jehanabad District 111

6.2 Seasonal Change of Satellite Image around Machala Ahars 112

6.3 Location and Satellite Images of Budhauli Ahar 115

6.4 Location of Siriyawan Village and Drainage System by Village 117

6.5 Ahar-to-Ahar Drainage System in and around Siriyawan Village 119

6.6 Distribution of Blocks Classified as Class D 124

6.7 Estimated Density of Ahar by 5'-by-5' Grid 125

8.1 Location of Punjab in India 162

10.1 Location of Study Area in Punjab 203

10.2 Location of Study Area in Tamil Nadu 210

10.3 Topography and Density of Dug Well in Upper Gundar River Basin, Tamil Nadu 


\section{Tables}

1.1 Irrigation in India in 1947-48 and 2013-14

1.2 GDP Share in India (\%) 9

2.1 Landholding by Caste in RM between 1864 and 2008

3.1 Types of Land in Khurda Region, 1836 (acres) 40

3.2 Types of Land in Garh Manitri, 1828-1830 (acres) 40

3.3 Village-wise and Caste-wise Numbers of Households in the Manitri Fort Area (around 1800) 41

3.4 Shares and Taxes of Offices (average per head) 46

3.5 Land Ownership by Caste in Garh Manitri, 1829-1830, 1911 (acres) 54

3.6 Types of Land in Garh Manitri, 1911 (acres) 58

4.1 Population Growth of Lower Bengal (1881-1931) 67

4.2 Total Imports of Cleaned Rice to Calcutta (1876) 82

5.1 Distribution of Tanks and Rainfall in Tamil Nadu, India 89

5.2 Rainfall and Tank Storage, Tamil Nadu 90

5.3 Trend in Tank-Irrigated Area, Tamil Nadu (\%) 90

5.4 Groundwater-tank Ecosystem Interface 92

5.5 Existing and Feasible Numbers of Wells in Tank Commands 93

5.6 Rainfall Variation in the Tank Regions 94

5.7 Change in Rainfall and Change in Well Density and Area Irrigated 94

5.8 Distribution of Soil Types in the Tank Regions (\%) 96

5.9 Type of Aquifer in the Tank Regions 97

5.10 Distribution of PU Tanks in the Tank Cascade based on Command Area 98

5.11 Distribution of PWD Tanks in the Tank Cascade based on

5.12 Well Density Influenced by Tank Location and Catchment Related Factors in the Tank Cascade 99

5.13 Well Density as Influenced by Other Factors 100

5.14 Production Loss and Well Failure Contributing for Poor Well
Investment

5.15 Aquifer-tank Ecosystem Development Scenarios 103 
6.1 Percentage of Irrigated Area to Total Cultivated Area by Water Source in Bihar

6.2 Profiles of Villages in Charge of Surveyed Ahars 114

6.3 Results of Principal Component Analysis 121

6.4 Results of Cluster Analysis 123

7.1 Number of Electric Pumpsets in India by Region 137

7.2 Diesel Pumpsets in India by Region from 1990-91 to 2010-11 139

7.3 Electric Pumpsets in India by Region from 1990-91 to 2010-11 140

7.4 Share of Electric Pumpsets (wells + tube wells) 141

7.5 Percentage of Agricultural Power Subsidy in Gross Fiscal Deficits of the Major State Governments 143

8.1 Changes in Punjab Land Use, 1960-2016 163

8.2 Gross Returns from Paddy and Wheat vis-à-vis Other Important Crops in Punjab (Rs./ha)

8.3 Effects of Water Conservation Technologies and Practices on Water Use

9.1 NPK Ratio by State

10.1 Characteristics of NK village, Ludhiana, Punjab 206

10.2 Production and Cost of Rice Production in Ludhiana, Punjab 208

10.3 Characteristics of S village, Madurai, Tamil Nadu 213

10.4 Production and Cost of Rice Production in Madurai, Tamil Nadu 


\section{Contributors}

Parisha Budhiraja works as Research Associate at Centers for International Projects Trust, India since 2016. She specializes in areas of impact evaluation, agricultural economics, environmental economics and climate change. She has conducted studies adhering to different Indian states. Her publications include "Forgone Agricultural Benefits due to Wind Erosion: The Case of Shelterbelt Plantations in Jaisalmer, Rajasthan" (Ministry of Environment, Forest and Climate Change Project), "Assessing the Vulnerability of Tribal Rural Households in India: Measuring the Current Status, Risks of Climate Shocks and Impact of Potential Interventions for Improving Rural Households" (Indian Journal of Agricultural Economics, 72(3)), "Sustainability of Farmer Producer Organizations under Agricultural Value Networks in India: A Case of Punjab and Gujarat" (Indian Journal of Agricultural Economics, 73(3)).

Sujata Das Chowdhury is an independent researcher working out of Kolkatta. Sujata has collaborated on several studies of water and livelihoods in West Bengal.

Koichi Fujita is serving as a Professor at the Center for Southeast Asian Studies, Kyoto University since 2006. He specializes in agricultural economics and rural socio-economic research in contemporary South and Southeast Asia, with an emphasis on land tenure, irrigation and water management, labor and employment, rural administration and organizations, and rural finance. Since 2015 he acts as the Convener of the National Institutes for Humanities project on "South Asian Area Studies" which is a collaborative research project based on a network of six centers in Japan. His publications include Economic Transition in Myanmar after 1988: Market versus Control (Co-edited with Fumiharu Mieno and Ikuko Okamoto) (2009), and Re-thinking Economic Development: The Green Revolutions, Agrarian Structure and Transformation in Bangladesh (2010). He also edited a special issue, "Socio-Economic Dynamics in a Tank-Irrigated Rural Area in Contemporary Tamil Nadu, India" (Japanese Journal of Southeast Asian Studies, Vol.49, No.1, June 2011) and a special issue "Credit 
Union Movement in Laos" (Co-edited with Akihiko Ohno) (Southeast Asian Studies, Vol.3, Supplementary Issue, March 2015).

Atsushi Fukumi, Ph.D., Associate Professor of Economic Development at the Department of Economics, University of Hyogo. He received his Ph.D. in Economics at Kobe University in 2002. Prior to joining University of Hyogo, he was a faculty member in Tokai University. His research interests are in political economy, power sector reform, fiscal policy and state finance in India. He has published several papers including "Political Economy of Government Expenditure: A Case of Power Subsidy in India (In The BRICs as Regional Economic Powers in the Global Economy, 2012, edited by Takahiro Sato. Slovic Research Center, Sapporo, Japan)" and "Institutional Quality and Foreign Direct Investment in Latin America and the Caribbean" (coauthored with Shoji Nishijima), Applied Economics, 2010, Vol. 42.

Tsukasa Mizushima is Professor Emeritus of the University of Tokyo. He specializes in the global history from South Asian perspectives. He was the Director of the Center for the Study of Contemporary India, the University of Tokyo (2010-2017), the President of the Japanese Association of South Asian Studies (2016-18), the President of the Historical Society of Japan (2009-10), and the General Secretary of the Asian Network of Historical GIS Studies (2012-present). He has organized a number of projects like "Long-term Trends of Indian Villages" that produced five-volume series under the title of India in Turbulence (Tokyo: Nihon Keizai Hyoronsya, 2014-15, in Japanese). Some of his publications are Hinterlands and Commodities: Place, Space, Time and the Political Economic Development of Asia over the Long Eighteenth Century (2014), Locality, Daily Life, and State - Challenges to the 21st Century (2012, in Japanese), Japan, Asia, and Globalization - Challenges to the 21st Century (2012, in Japanese), Environment and Historical Studies: New Frontier of Historical Studies (2010, in Japanese), An Introduction to Global History (2010, in Japanese), etc. His articles appeared in books or journals such as A Concise History of South India: Issues and Interpretations (2014), The Indian Economic and Social History Review, Journal of Japanese Association for South Asian Studies, etc.

Mohanasundari Thangavel is working as Assistant Professor (Agricultural Economics) in the College of Agricultural Sciences, Namakkal, Tamil Nadu, India. She did her M.Sc. dissertation on "Rainfall Induced Climate Variability and its Impact on Groundwater Irrigation in Tamil Nadu" and her Ph.D. works on "Adaptation of Agrosilvipastoral System to the Changing Climate Scenario of Western Tamil Nadu". She has published many papers in national and international journals and also as book chapters.

Kuppannan Palanisami is an Agricultural Economist specializing in water resources. He has worked in numerous different countries and has handled several projects on water and climate. He was a principal researcher at International Water Management Institute (IWMI), Hyderabad from 2008-2015 
and is currently serving as an Emeritus Scientist at IWMI. He has continued his tank irrigation research for the past 40 years and has published 2 books and about 20 papers and book chapters exclusively on tank irrigation.

Takahiro Sato is Associate Professor at Faculty of Agriculture and Life Science, Hirosaki University. He received his Ph.D. in Agriculture from Kyoto University, where he performed ecophysiological studies on the timing of supplemental irrigation in northern Syria. He began his studies of transformation of Indian agriculture in 2006, and his current research focuses on semi-arid agriculture and rural development. His various publications on this subject include: "The Effect of Expansion of Private Wells on Rural Livelihood in Tank Intensive Watersheds: A Case Study in Upper Gundar River Basin, Tamil Nadu" (Southeast Asian Studies 49), "Beyond Water-Intensive Agriculture: Expansion of Invasive Tree Species in Tamil Nadu, India" (Land Use Policy 35), and "Livelihood Transformability of Indian Villages with Poor Water Resources: The Case of Tamil Nadu" (Senri Ethnological Studies 96).

Tetsuo Satoh is a professor at the Department of Geography, Komazawa University in Tokyo. His specialty is land use analysis and resource management in South and Southeast Asia. He obtained his Doctoral Degree (Science) in 1993 from the University of Tokyo with a dissertation entitled A Geographical Study on Farming Systems in Rice Growing Regions of Asia. Recently, he has led a collaborative research project on "Environmental Base of Water Resource Utilization in South Asia" for the Institute for Applied Geography at Komazawa University. He also takes part in several action research projects to support Thai farmers' nature conservation activities. One publication resulting from this has been Local Land Use Planning with PGIS in Protected Areas of Thailand (co-authored with Phonpat Hemwan) (Regional Views, No. 29).

Ippei Sekido is a Project Researcher at the Graduate School of Arts and Sciences, the University of Tokyo and also a Research Fellow at National Institutes for the Humanities. He served as a Research Fellow (2016) at the Graduate School of Humanities and Sociology, the University of Tokyo. His areas of research are environmental sciences, environmental economics, agricultural economics, and historical GIS (Geographic Information System). He studies long-term environmental and economic change of South Asian countries and Japan with an emphasis on nitrogen cycle, food supply, water pollution, demographic change, and land use.

Tushaar Shah, an economist and public policy specialist, is Professor Emeritus at Institute of Rural Management, Anand (India) and Scientist Emeritus at International Water Management Institute, Colombo. Over the past 35 years, Shah's main research interests have been in water institutions and policies in South Asia, a subject on which he has published extensively. His notable contributions have been in comparative analyses 
of groundwater governance in South Asia, China and Mexico. More recently, his interests have been in comparative analyses of water institutions and policies across Asia and between South Asia and Sub-Saharan Africa. Shah has also worked extensively on energy-irrigation nexus in India. Shah was honored with the Outstanding Scientist award of the Consultative Group of International Agricultural Research (CGIAR) in 2002. In 2014, the IWMI-Tata Program led by Shah was honored with the United Nations Water Award for its work on energy-water nexus and later received the Distinguished Associate Award of International Association of Hydrogeologists (IAH) in 2018.

Akio Tanabe is a Professor at the Graduate School of Arts and Sciences at the University of Tokyo. He specializes in anthropological and historical research of South Asia, with an emphasis on caste and religion; democratisation and social change; and South Asian paths of development. He served as a Professor (2009-2016) at the Graduate School of Asian and African Area Studies and the Director (2010-2016) of the Center for the Study of Contemporary India, Kyoto University before shifting to the University of Tokyo. He also acted as the Convener (2010-2015) of the National Institutes for Humanities project on "Contemporary India Area Studies" which is a collaborative research project based on a network of six centers in Japan. This project resulted in the publication of Contemporary India vol. 1-6 (Tokyo: University of Tokyo Press, 2015, in Japanese). He has authored Caste and Equality: Historical Anthropology of Local Society and Vernacular Democracy in India (2010, in Japanese), and co-edited Human and International Security in India (Routledge), Democratic Transformation and the Vernacular Public Arena in India (Routledge), The State in India: Past and Present, and Gender and Modernity: Perspectives from Asia and the Pacific among others. His articles have appeared in journals such as Modern Asian Studies, American Ethnologist, South Asia and Journal of Japanese Association for South Asian Studies, amongst others.

Shinkichi Taniguchi is a Professor Emeritus of Hitotsubashi University, Tokyo. He taught at Hitotsubashi University (1979-2011) and Tokyo University of Foreign Studies (2012-2017), and retired in 2017. He studied agrarian history of Bengal in the early colonial period in his doctoral dissertation, and obtained a Ph.D. (Arts) degree in history from Calcutta University in 1978. He published a number of articles on various aspects of agrarian societies of Bengal. These include "The Permanent Settlement in Bengal and the Breakup of the Zamindari of Dinajpur," The Calcutta Historical Journal, Vol. III-1, 1978, "The Patni System-A Modern Origin of the Subinfeudation of Bengal in the 19th Century," Hitotsubashi Journal of Economics, 22-1, 1981, "Situating Market Relations in the Late 18th Century Bengal," in Proceedings of Indian History Congress, 56th Session, 1996, "The peasantry of northern Bengal in the late 18th 
century," in P. Robb, K. Sugihara \& H. Yanagisawa (eds.), Local Agrarian Societies in Colonial India, Curzon, 1996, "Rethinking the Bengal Peasantry in History", in Agrarian and Other Histories Essay For Binay Bhushan Chaudhuri, edited by Shubhra Chakrabarti and Utsa Patnaik, Tulika Books, New Delhi, 2017.

Dr Kamal Vatta is an agricultural economist and is currently Professor and Head of the Department of Economics and Sociology, Punjab Agricultural University, Ludhiana. Prior to this, he was Director of the Centers for International Projects Trust, New Delhi for more than 5 years. A gold medalist in Ph.D. (Agri. Economics) from Punjab Agricultural University, he has also completed an advanced diploma in Agricultural Research for Development from The Netherlands and underwent advanced training in quantitative economics at Columbia University, New York, USA. He has worked extensively on natural resource management, especially groundwater, agricultural policy, integrated rural development and non-farm sector in India. He has more than 100 publications of international and national repute and has also participated in more than 100 international and national conferences, seminars, workshops, etc. He has been Adjunct Research Scientist at Columbia Water Center, Columbia University, New York, USA and visiting researcher to Kobe University, Japan and Kazakh National Agrarian University, Kazakhstan. 


\section{Preface}

This volume is the outcome of an international symposium titled "Toward Sustainable Development of India and South Asia" held in Kyoto in December 17-18, 2016. The symposium was organized by the Integrated Area Studies on South Asia project (INDAS-South Asia), which has been financially sponsored by the National Institutes of Humanities (NIHU), Tokyo. Six research centers in Japan, including Kyoto University, National Museum of Ethnology, The University of Tokyo, Hiroshima University, Tokyo University of Foreign Studies, and Ryukoku University, are playing core roles in the project, though members from some other institutions are also actively involved.

The symposium was an intense, stimulating, and exciting one. We are grateful to Kohei Wakimura, Hidenori Okahashi, Kaoru Sugihara, Hisaya Oda, Yasuyuki Kono, and Akihiko Ohno, for presiding over the sessions and/or providing stimulus comments. It goes without saying that no such attempts could take place without administrative help. We are grateful to the post-doctoral researchers and staff of the INDAS-South Asia project and the graduate students from the Graduate School of Asian and African Area Studies, Kyoto University, including Toru Taku, Yoshiaki Takemura, Kanako Nakagawa, Miharu Yui, Maya Suzuki, Kenta Funahashi, Kaoru Kawanaka, Sumito Mizusawa, Seiko Tsuruta, Takuya Miyazono, Saori Nishikawa, Aya Tanaka, and Hiromi Takahshi, for supporting the symposium. Last but not least, thanks go to all the participants for the comments and discussion during the symposium.

In addition to the paper readers, we requested Akio Tanabe, Shinkichi Taniguchi, Tetsuo Sato, and Kamal Vatta to contribute in order to make this volume more holistic and consistent with the main theme (it is regretful that the papers by Arun Bandopadhyay and Daizo Sugimoto are not included here).

For its publication we are very much grateful to the series editors, especially Crispin Bates and Minoru Mio, for advices with unflinching commitment and quality. We would also like to thank Alexandra de Brauw and Dorothea Schaefter, for their constant support and the reviewers at Routledge for putting the product on the market. 
xviii Preface

Lastly, we the contributors do hope to receive comments from the readers to enrich understandings of South Asian society.

Koichi Fujita and Tsukasa Mizushima 


\title{
1 Introduction
}

\author{
Koichi Fujita
}

PROFESSOR, CENTER FOR SOUTHEAST ASIAN STUDIES, KYOTO UNIVERSITY

\section{Tsukasa Mizushima}

PROFESSOR EMERITUS, THE UNIVERSITY OF TOKYO

In the mid-1990s, India solved its persistent food difficulties and entered a new stage of economic development. The bottleneck of water stress was overcome by using fossil energy resources, such as electricity and diesel oil, to lift groundwater efficiently. However, resolving one issue has led to another. Today, India faces severe groundwater depletion and an energy crisis exacerbated by bankruptcies in the power sector. The sustainable development of the country has been jeopardized through the erosion of the food production base and also India's overall economic performance. This book seeks to explore and interrogate the 'food-water-energy nexus,' arguably the most crucial factor in sustaining India's economic development.

The food-water-energy nexus is a complicated phenomenon in which the three named elements are closely inter-related. Firstly, agriculture, namely food production, in India and South Asia is primarily located in semi-arid tropics and is therefore highly dependent on groundwater resources. Secondly, lifting groundwater by using wells (including tube wells and bore wells) has become increasingly dependent on fossil energy in the form of diesel oil or electricity. Hence food production is profoundly affected by (international) oil prices and very vulnerable. In addition, in many Indian states, as discussed later in detail, electricity used in agriculture was subject to a 'flat-tariff' after the mid-1970s, causing a series of problems. These included inducing farmers to exploit groundwater excessively, as the fixed electricity fee meant that costs were disconnected from actual electricity consumption. Now, the resulting groundwater deletion endangers the sustainability of food production in the future. Also, the huge losses caused by the agricultural power subsidy has damaged the financial condition of the State Electricity Boards (SEBs) and impacted electricity supply in India, causing chronic power shortages and a low quality of power supply, as exemplified by frequent power outages and interruptions and fluctuating voltage in all sectors, not just agriculture. The flat tariff has resulted in a heavy fiscal burden for many Indian state governments.

This book is divided into two parts, each composed of five chapters. Part I, 'Land, Water, and Population in the Past and Future,' deals with the historical background and future prospects of land, water, and rural livelihood 


\section{Koichi Fujita and Tsukasa Mizushima}

in India and South Asia. Part II, 'Regional Path Dependencies and Policy Orientations for Sustainability, deals with the contemporary issues of land, water, and food production.

Although Part II is more directly related to the contemporary issue of the food-water-energy nexus, all the chapters are relevant. ${ }^{1}$ Our approach emphasizes regional disparities within India as well as South Asia and incorporates the historical path of dependency in each region to clarify the complex realities they face. In Part I, Chapters 2-4 deal with the historical development of land reclamation and related agrarian change in nineteenth century Tamil Nadu, Orissa, and Bengal, respectively. Chapters 5 and 6 discuss the present status and future prospects of land and water (focusing on traditional water reservoirs) issues in Tamil Nadu and Bihar, respectively.

In Part II, Chapter 7 is an overview of the food-water-energy nexus in India and South Asia and thus the core chapter of the book. Chapter 11 also directly deals with the same issue in Gujarat and West Bengal, while focusing on groundwater markets in the light of different types of policy reform aimed at combating the nexus issue. Chapter 8 is a case study of the nexus in Punjab that seeks to address the agricultural sustainability issue there in a more holistic way. Chapter 10 consists of a comparative study of the nexus in Punjab and Tamil Nadu, focusing on groundwater irrigation and food production. Chapter 9 explores the use of chemical fertilizer (in particular, urea) in relation to the fertilizer subsidy policy in India, which, in terms of competition for limited governmental financial resources, is inherently linked to the issue of power subsidy.

Let us now explain how these ten chapters are part of the wider narrative encompassed by this book.

\section{Plan of the book: part I}

India, particularly the western half of the country, is located in a peripheral area of Monsoon Asia, an area with arid/semi-arid climate. Another peripheral area is northern China. Although Monsoon Asia has historically supported huge populations with its seasonal but abundant rainfall, these two peripheral areas have been adversely influenced by low and erratic rainfall and the concomitant water stress that affects stable crop production. Farmers in both areas therefore depend heavily on well irrigation for agriculture, a dependence that is causing severe groundwater depletion today (Mukherji et al., 2009). However, at least two major climatic differences exist between India and northern China. Whereas China is situated mainly in the temperate zone, India is in the tropical zone. Given equal amounts of rainfall, the water stress is more oppressive in the tropics because of the high water evaporation rate and a more erratic pattern of rainfall. In addition, the area with more than 6-7 'dry months' (defined roughly as a month with rainfall of less than $40 \mathrm{~mm}$ ) in a year is much larger in India than in China (Takaya, 1985). In other words, the distinction between the wet season and 
the dry season is stark in India, leading to more water stress in India than in China. Groundwater is thus used more extensively for agriculture in India, even in its humid eastern half.

Throughout its long history, India has come up with many responses and adaptations in reaction to its low and erratic rainfall. The impact of these on water stress can be broadly split into two categories: those related to social systems and those related to water use technologies. With regard to the former, both Mizushima (Chapter 2 'Land Development and Demographic Change in Tamil Nadu from the Late Eighteenth Century to the Early Twentieth Century') and Tanabe (Chapter 3 'From Sharing Risks to Taking Risks: System of Entitlements and its Fragmentation in Eighteenth and Nineteenth Century Orissa') emphasize the highly flexible nature of the pre-colonial social systems, defined variously as the mirasi system, the system of entitlements, vatan, and by other terms. By adjusting the proportional shares of collective products among people in the locality, these systems sustained the lives of those who performed distinctive roles in local society in the face of extreme climatic instabilities. They offered 'multilayered safety nets' that were destroyed by the colonial land system, the so-called raiyatwari system, which created a completely different social structure based exclusively upon landholding, resulting in the loss of sustainability. These findings are related closely to the fragile characteristics of the food-water issue, a theme at the heart of this book. Mizushima and Tanabe ultimately claim that the path of development followed during the colonial period was fundamentally pre-determined by a land system that prioritized individual interests over the burden of sustaining local society, leading to an overexploitation of local resources such as land and water. Outside of Tamil Nadu, Orissa, and Maharashtra, the same social development trajectory in other parts of India has not been explicitly explored. However, the symbiotic relation between social systems and the so-called caste system, as shown in the linking of the share system with the occupational structure among castes, implies the prevalence of similar pre-colonial and colonial systems throughout the Indian subcontinent.

Although this book premises regional differences in development in India both in the early modern and the colonial period, some similarities among regions in the impact of colonialism are observed. Despite being placed in completely different colonial land systems, both Tamil Nadu and Bengal experienced high rates of population growth and land development, which one might call economic development. This is observed by Mizushima in Tamil Nadu from the beginning of the nineteenth century (Chapter 2) and by Taniguchi in Bengal (Chapter 4 'Bengal Agrarian Society during late Colonial Rule: the Development of the Sundarbans'), especially in relation to the Sundarbans during the colonial period. Pushed by the rise of agricultural prices in the late nineteenth century, which resulted from India's intensified involvement with the growing world economy of the period, both regions achieved rapid economic growth. They also, however, experienced 


\section{Koichi Fujita and Tsukasa Mizushima}

severe threats to sustainability by the late nineteenth century. Mizushima links the great famines that occurred during the late nineteenth century with the results of overexploitation and Tanabe adds the loss of livelihood security as a cause of catastrophic famine, especially among the underprivileged people, in Orissa. Taniguchi traces agrarian change in the Sundarbans in Bengal, which is currently facing serious environmental problems, and finds that the economic development there produced a highly stratified agrarian society with destitute cultivators at its bottom. He sees this as a lasting factor in the continued retardation of agricultural production.

It can be argued that India's colonial development occurred at the cost of a social system that maintained a hierarchical structure but provided the flexibility to mitigate natural calamities. In the nineteenth century, the structure that emerged under colonialism intensified economic stratification and, in many parts of India, high population growth and the overexploitation of land led to the deterioration of agricultural production. Against this backdrop, what choices did India have? The approach that was taken to confront this situation lay in the management of water resources; exploiting more water for irrigation was seen as a vital ingredient in stabilizing and intensifying agricultural production.

Three major types of water use technologies have been adopted in the past: 1) lifting water from wells (groundwater) or small reservoirs/streams (surface water); 2) constructing tanks in a gently sloped river-basin for storing seasonal rainfall, with water drawn from the tanks by gravity; 3) diverting water from rivers by gravity, including 'inundation irrigation"2 (Tada, 1992). ${ }^{3}$ The first category of irrigation was historically operated by human labor or draft animal labor. People used a variety of water lifting implements. These included a doon and swing basket ${ }^{4}$ (for surface water), a manually operated shadoof (dhenkuli), a shadoof pulled by cattle on a slope (moht or charas), a Persian wheel (rahat), and a washer rahat (for groundwater) (Dakshinamurti et al., 1973). The Persian wheel was the most popular implement and was used widely in India in the first half of the twentieth century after undergoing three major technological improvements; its frame changed from wood to iron, the buckets became light aluminum rather than heavy earthenware, and metal roller bearings were introduced to reduce friction between moving parts (Islam, 1997).

Although well irrigation on a large scale was a salient feature of agrarian life in western and northwestern India, in eastern and southern India it was largely absent around 1800 and still very limited by 1900 (Shah, 2009). In contrast, the second category of irrigation technologies (tanks) supplied water for agriculture in southern parts of India such as Andhra Pradesh, Tamil $\mathrm{Nadu}$, and Karnataka. An irrigation tank is a small reservoir constructed across the slope of a valley to catch and store water during the rainy season for future use. Many tanks, now a common feature of the South Indian cultural landscape, were built in the past centuries by kings, zamindars, and even the British rulers (Palanisami and Easter, 2000). ${ }^{5}$ The third category of 
irrigation (canals) was developed mainly in northern parts of India, especially on the Indo-Ganges Plain. During the British colonial period, many restoration and construction projects were undertaken across India.

Immediately after India gained its independence in 1947, according to government statistics (Table 1.1), 19 percent of the net sown area was irrigated, of which 42 percent was irrigated by canals, 17 percent by tanks, 27 percent by wells, and the remaining 14 percent by other methods (Johnson, 1979a). Roughly two-thirds of net irrigated areas were concentrated in 'North-central' and 'South' regions, followed by the "Northwest" with another 18 percent. However, irrigation, especially well irrigation, expanded very rapidly thereafter. In 2013-14, the ratio of net irrigated area (to net sown area) jumped to 48 percent, of which 24 percent was by canals, 3 percent by tanks, 62 percent by wells, and 11 percent by others. Well irrigation became by far the most dominant mode of irrigation while tank irrigation lost its importance to a considerable degree. ${ }^{6}$ Considered by region, the share of 'West and Central' of the total net irrigated area jumped from 8 percent to 27 percent, whereas that of the 'South' declined from 32 percent to 19 percent.

Table 1.1 Irrigation in India in 1947-48 and 2013-14

\begin{tabular}{llclccc}
\hline Region & Year & $\begin{array}{c}\text { Share in } \\
\text { total net } \\
\text { irrigated } \\
\text { area (\%) }\end{array}$ & Canal (\%) & Tanks (\%) & Wells (\%) & Others (\%) \\
\cline { 6 - 7 } & & & & & \\
\hline Northwest & $1947-48$ & 18 & 63 & 2 & 32 & 3 \\
North- & $1947-48$ & 34 & 34 & 10 & 37 & 20 \\
central & $2013-14$ & 26 & 20 & 1 & 77 & 1 \\
Northeast & $1947-48$ & 8 & 30 & 27 & 6 & 27 \\
& $2013-14$ & 6 & 4 & 0 & 2 & 93 \\
West and & $1947-48$ & 8 & 50 & 5 & 41 & 4 \\
Central & $2013-14$ & 27 & 24 & 2 & 66 & 8 \\
South & $1947-48$ & 32 & 38 & 34 & 15 & 12 \\
& $2013-14$ & 19 & 28 & 9 & 48 & 15 \\
INDIA & $1947-48$ & 100 & 42 & 17 & 27 & 14 \\
total & $2013-14$ & 100 & 24 & 3 & 62 & 11 \\
\hline
\end{tabular}

Source: Prepared by author based on data from Johnson (1979a) and Directorate of Economics \& Statistics, Ministry of Agriculture and Farmers Welfare, Government of India.

Note: 1) The category of the region is as follows.

Northwest: Haryana, Himarchal Pradesh, Jammu \& Kashmir, Punjab, Rajastan and Delhi.

North-central: Bihar and Uttar Pradesh.

Northeast: West Bengal, Assam and Northeastern States.

West and Central: Gujarat, Madhya Pradesh and Maharashtra.

South: Andra Pradesh, Kerala, Karnataka, Orissa, and Tamil Nadu.

2) The share of 'Others' in Northeast in 2013-14 is very high because all the irrigated areas in West Bengal are classified in 'Others.' 
In southern India as well, where tank irrigation was traditionally important, well irrigation expanded rapidly. In Tamil Nadu, for example, where farmlands are classified into nanjai (tank command areas for wet rice cultivation) and punjai (outside tank command), wells were first introduced into punjai, but more recently in nanjai as well. This is mainly because of the accelerated deterioration of tanks in recent years (Palanisami, 2000; Mosse, 2003; Muniandi and Fujita, 2011). This expansion may partly be the result of climatic change, but it is mainly attributable to rapid economic development in Tamil Nadu. The labor wage hike was particularly significant. It made the maintenance of rural infrastructure such as tanks increasingly difficult, and as more tanks have malfunctioned, farmers have been forced to rely to an ever greater degree on private wells (Palanisami and Balasubramanian, 1998; Sato and Duraiyappan, 2011).

It is noteworthy, however, that even in areas where traditional water reservoirs (tanks or ahar) have lost their importance as the source of surface water irrigation, groundwater is at least partly refreshed by such reservoirs in the locality. Under the accelerated rural-urban and overseas migration and the resulting acute labor shortage in rural India, the maintenance of traditional water reservoirs is an important policy agenda. Chapter 5 (Palanisami and Mohanasundari, 'Sustaining Tank Irrigation in South India through Time-Tested Measures') and Chapter 6 (Tetsuo Satoh, 'Ahar: A Traditional Irrigation System in Southern Bihar') address this issue respectively in the cases of tanks in Tamil Nadu and ahar in southern Bihar. Palanisami and Mohanasundari unveil the dynamics of the tank-well relationship in Tamil Nadu and the possibilities for reviving tank ecosystems as a rural livelihood enhancement strategy. They pay special attention to the contrast in difficulties between the northern state (tank-intensive area) vs. southern state, head reach area vs. tail reach area (of river basin), and Panchayat Union (PU: with less than 40 ha command) tanks vs. Public Works Department (PWU: with more than 40 ha) tanks. Recognizing the need for a more conjunctive use of tank and well water, they estimate that the number of wells could be increased by 21 percent in the tank command areas in the state.

Tetsuo Satoh in Chapter 6 provides precise information related to the local-level realities of the two types of ahar (ahar-pyne and rainfed ahar) in southern Bihar, based on recent field surveys, satellite images, and Google Earth maps. In addition, he estimates the locations, area and water storage capacity of ahar in Bihar using the Village Level Amenity Data (2001) and suggests several important policy implications for better regional-level water management (including well irrigation) in southern Bihar.

Both Chapters 5 and 6 try to focus on the current situation and argue for an optimum management system for tanks and ahar. They provide a historical background concerning water usage processes and the irrigation system. Tank irrigation was hierarchical from the very beginning; during the precolonial period, tanks and ahar were often constructed and managed by 
local leaders like zamindars with coerced labor, but the water was usually too limited to enable even distribution among the community. Under the colonial administration this was exacerbated and the collapse of communal 'unity' made the government's attempts to revive the local community tank system unworkable. After Independence, the Indian government followed the British policy, but the situation deteriorated and tank (including ahar) irrigation has declined substantially. Well irrigation, which is under individual control, now occupies a dominant position. This, however, does not negate the necessity and potential of tank irrigation. Tanks continue to be an important source for replenishing groundwater, and in this sense, balancing well irrigation and tank irrigation remains a key issue for the sustainability of agriculture. Chapters 5 and 6 highlight this point and illuminate the complicated policy-making involving the state, community, individual, and market that are relevant to it.

\section{The food-water-energy nexus and its regional structure}

The most important technological innovation for Indian agriculture was the introduction of wells serviced with diesel engines and electric motors for lifting water (hereinafter, energized wells) towards the end of the nineteenth century. This evolution in technology replaced draft animals and enabled well irrigation to rapidly develop (Islam, 1997). Energized wells were a vital part of the Green Revolution that occurred in India from the late 1960s. ${ }^{7}$

Figure 1.1 shows the long-term trend of population and (net) production/ export of cereals in India after Independence. As indicated by the large amounts of cereals imported in the mid-1960s, India was hit by a two-year consecutive drought. Subsequently, the government undertook a strong initiative to increase food production by introducing new agricultural technologies and associated institutional supports such as purchasing (mainly) rice and wheat by the government at minimum support prices (MSPs). Based on a detailed production cost survey taken annually, the MSPs were set at a level where farmers could secure a sufficient profit after meeting all expenses and were announced before the sowing season. The government was obligated to purchase what farmers wanted to sell.

At first, the Green Revolution strategy was successful only in limited areas such as northwestern India and some parts of southern India. Therefore, although India attained self-sufficiency in cereal production by the end of the 1970s (Figure 1.1), per-capita income remained low. Rural mass poverty largely persisted. In the next decade, however, a more rapid (3.9 percent per annum on average) and more inclusive growth of agriculture took place (Fujita, 2015). This expansion was a result of the dissemination of Green Revolution technologies, especially energized wells, throughout other parts of India including the eastern and central parts. By the end of the decade, rural incomes had risen considerably. This enhanced purchasing power for non-agricultural goods and services in rural areas, fulfilling an important 


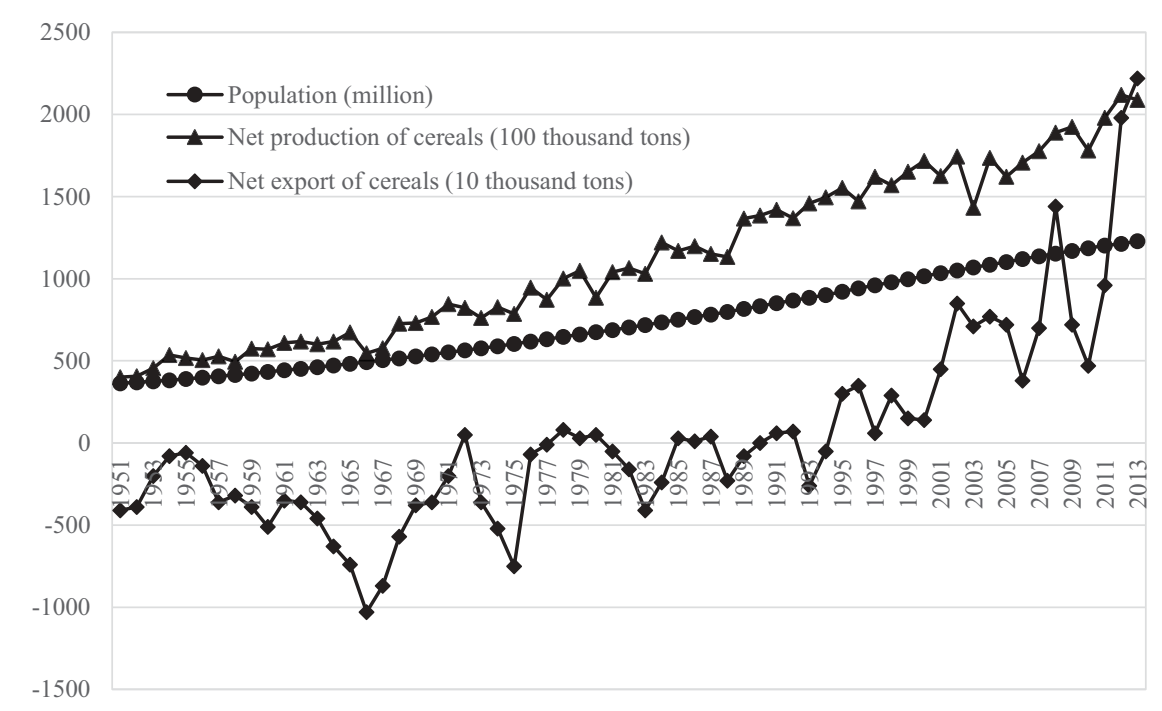

Figure 1.1 Population and Net Cereals Production and Export in India

prerequisite for high and sustained economic growth in India from the early 1980s. ${ }^{8}$

In 1995, India sent the world an unmistakable signal that the Indian economy had departed from the 'food problem' stage and entered an 'agricultural adjustment problem' stage (Hayami, 1986): it emerged suddenly as an exporter of large quantities of rice in the world market. The struggle to resolve food difficulties was finally over, ${ }^{9}$ mainly because water for agriculture had been secured through the introduction of energized wells, but also due to the use of high yielding varieties (HYVs), chemical fertilizers, and other chemicals. Tractors, combine harvesters, and other agricultural machineries also played an important role. The rate of increase in food production far exceeded the population growth rate.

It is interesting to observe that the relative importance of the agricultural sector in the economy declined throughout this process (Table 1.2). The share of agriculture (including forestry, fishery, mining and quarrying) in GDP, which was 53.7 percent in 1950-51, decreased successively to 49.8 percent (1960-61), 43.9 percent (1970-71), 38.3 percent (1980-81), 33.0 percent (1990-91), 25.2 percent (2000-01), and 16.8 percent in 2010-11. However, it is noteworthy that the share of employment in agriculture is still 49.7 percent (2010-14). Moreover, the population proportion that remains rural is as high as 67.3 percent (2015) (UNDP, 2016). Although agriculture has become a minor industry in terms of value added, rural areas are still vital in terms of population and employment. 
Table 1.2 GDP Share in India (\%)

\begin{tabular}{llll}
\hline & Primary industry & Secondary industry & Tertiary industry \\
\hline $1950-51$ & 53.7 & 14.4 & 31.9 \\
$1960-61$ & 49.8 & 17.9 & 32.3 \\
$1970-71$ & 43.9 & 21.4 & 34.7 \\
$1980-81$ & 38.3 & 23.0 & 38.7 \\
$1990-91$ & 33.0 & 24.1 & 42.9 \\
$2000-01$ & 25.2 & 24.3 & 50.5 \\
$2010-11$ & 16.8 & 25.7 & 57.5 \\
\hline
\end{tabular}

Source: Government of India, Economic Survey 2015-16.

Note: In term of constant prices.

As previously mentioned, solving one difficulty often brings about others. India is now facing the interrelated obstacles of groundwater depletion and energy crisis. Although the former jeopardizes the food production base, the latter extends beyond the agricultural sector and affects overall economic development. Designated herein as the food-water-energy nexus, these entangled issues will have far-reaching consequences for sustainable development.

\section{Plan of the book: part II}

The introduction of the flat-tariff for the agricultural use of electricity by Indian state governments in the decade following the mid-1970s is key to the formation of the nexus. It provided farmers with a strong incentive for reckless electricity use in lifting groundwater because the marginal cost for power consumption approached zero (Shah, 1993). The wrong economic signal given to farmers by the flat tariff also provided the officials of State Electricity Boards (SEBs) with illicit opportunities. Actual agricultural electricity consumption could not be easily identified and there was a clear incentive to over-report power consumption by the agricultural sector in order to obtain more subsidies from state governments. By abusing these circumstances, the SEBs could and did conceal their managerial inefficiencies.

The financial crisis of the SEBs has hindered investment in new power plants and the maintenance of the existing power infrastructure. This in turn has led to an unreliable and inadequate power supply that frequently leads to power outages, unstable voltages and unpredictable frequencies. The ill effects extend into all economic sectors, including industry and commerce. To make matters worse, farmers who have been adversely affected by poor and inadequate power supplies have become opposed to raising the power rates paid for agricultural operations.

The food-water-energy nexus involves clear regional differences that are sometimes counterintuitive. The nexus in the arid/semi-arid western half of 
the Indian subcontinent, where groundwater resources are scarce, has been aggravated severely. ${ }^{10}$ By contrast, in the humid eastern half of the subcontinent, including Nepal Terai and Bangladesh, the issue is less severe. This is the case not only because of the abundance of groundwater in the latter area but also because most of the tube wells are diesel-operated due to delayed rural electrification. For the limited number of electric tube wells in the area, the flat-tariff system was never introduced, or abandoned after some time. ${ }^{11}$ These differences skew the basic policy agenda differently in the respective regions. In the former area, it is imperative to solve the severe and complicated issue of the nexus, but in the latter area, promoting rural electrification and expanding well-irrigated areas is necessary to boost agricultural production and to accelerate measures against rural poverty.

However, it should be noted that the issue of the food-water-energy nexus exists in other forms in the eastern half of the Indian subcontinent. Because most of the tube wells are diesel-operated, the market price of oils directly affects pump irrigation and thereby food production. It is the farmers rather than the governments that suffer as a result of this. In Bengal including West Bengal and Bangladesh, for instance, after the land frontier disappeared by the end of the nineteenth century, when the reclamation of the Sundarbans reached its limit as Taniguchi describes in Chapter 4 of Part I, the agricultural sector experienced a prolonged stagnation until private tube wells (especially shallow tube wells) were disseminated on a large scale after the 1980s (Rogaly et al. ed., 1999). ${ }^{12}$ After this diffusion, the food-water-energy nexus emerged in a different form: (international) oil prices were now tied up with irrigation water and food production.

Geological features form the basis for another important regional disparity. India can largely be divided into 1) alluvial floodplains such as the Indo-Ganges Plain starting from Punjab (including Pakistan Punjab) to West Bengal (and Bangladesh) and 2) hard-rock areas of the Deccan Plateau. Whether a region is located in an alluvial plain or in a hard-rock area affects the aquifer condition. Digging wells in the latter costs far more and requires more labor (Dawan, 1986).

In Part II of this book, aside from broadly addressing all of India (and South Asia), several states including Punjab, Gujarat, Tamil Nadu, and West Bengal are specifically examined. The food-water-energy nexus manifests differently in each. In terms of climate, Punjab, Gujarat, and Tamil $\mathrm{Nadu}$ belong to the arid/semi-arid western half of the Indian subcontinent. ${ }^{13}$ All of them are strongly and adversely affected by the foodwater-energy nexus issue. By contrast, West Bengal, with its more humid climate, faces a different situation, with a high dependence on dieseloperated tube wells. The nexus issue takes a different form there.

As to the geological features, Punjab and the major portion of Gujarat are located in alluvial plains, whereas the major part of Tamil Nadu is in hard-rock areas. It goes without saying that Punjab is by far more blessed than others, being well known as the 'Indian granary. ${ }^{14}$ The food security 
of the country depends strongly on the food production performance in Punjab and the state therefore occupies a special position in the economy of India.

Hard-rock areas present more difficulties. The 'core' hard-rock areas in India include the states of Karnataka (97 percent of the area is in the hardrock) and Maharashtra (94 percent), followed by Andhra Pradesh (including the new state of Telangana) (88 percent). Tamil Nadu is not in the core area, but its percentage of hard-rock area is 76 percent (Dawan, 1986). As Dawan (1986) emphasized, the conjunctive use of surface water and groundwater is a key in such hard-rock areas. It can be argued that extending the network of surface irrigation to low and uncertain rainfall areas can enrich groundwater supplies to enhance returns from investment in well irrigation in these areas.

Many reports of the relevant literature refer to the food-water-energy nexus in India and South Asia. ${ }^{15}$ Fujita and Fukumi (Chapter 7 'Overview of the Food-Water-Energy Nexus in India and South Asia') summarize arguments on the issue by asking why and how the flat electricity tariff for agriculture was introduced into India since the mid-1970s. Then they explain how the nexus emerged and developed. The two difficulties of groundwater depletion and bankruptcies in the power sector are investigated with special reference to regional disparities. Some major arguments related to how to tackle the nexus at the policy level are also taken up for study.

Another issue discussed by Fujita and Fukumi is the groundwater markets. This is vitally important in terms of equity in the well irrigation economy because most resource-poor small/marginal farmers and sharecroppers purchase irrigation services in these markets. Moreover, the food-waterenergy nexus is closely linked to the functioning of the groundwater markets at the local level. For instance, as Shah (1993) argued, under the flat tariff, because of the near-zero marginal cost for electricity consumption, well owners tend to set irrigation service charges at lower levels in various parts of India and South Asia if there is sufficient competition among the well owners in the locality.

Vatta and Budhiraja present a detailed account of the sustainability issue of Punjab agriculture in Chapter 8 ('Challenges of Growth and Sustainability: Agriculture in Indian Punjab'). While touching upon the food-waterenergy nexus issue, they offer a much wider context from which to regard it. In the final part of their investigation, several concrete remedial measures are proposed for more sustainable agriculture in Punjab, including crop diversification, efficient water use, soil health management, and organic farming. Although Vatta and Budhiraja argue the sustainability of agriculture in Punjab in general, their focus is mainly on the structure of groundwater overexploitation and the related free electricity policy, as mentioned in the conclusion of the chapter.

Following Chapter 8, which presents discussion of the excess and imbalanced input of chemical fertilizers in Punjab, Sekido in Chapter 9 ('Nitrogen 
Cycle and Fertilizer Subsidy in India') investigates the difficulties posed by environmental pollution caused by nitrogen input in India with comparison to China by application of a nitrogen model. His major argument is related to the roles and difficulties of the fertilizer subsidy policy in India. The fertilizer subsidy is as important as the power subsidy in terms of financial burdens upon the government. So far as food production and supply is concerned, there is no doubt that the stable supply of nitrogen plays a critical role. Sekido argues that the food and energy balance moves in a contradictory way because the maintenance of the fertilizer subsidy policy is creating a huge financial deficit that competes with the power subsidy policy under the limited governmental budget. Sooner or later, the government will face a serious dilemma in deciding which should have priority. To avoid this conundrum, Sekido argues that it is essential for the government (including state governments) to plan and enforce an efficient method for supplying nitrogen fertilizer.

Takahiro Sato, in Chapter 10 ('Sustainability of Groundwater-Irrigated Agriculture in India: Case Studies of Punjab and Tamil Nadu') emphasizes the contrast in groundwater use and its depletion between Punjab in the alluvial plains and Tamil Nadu in the hard-rock areas. In the situation in India, where particular issues are often discussed separately in each state because of differences in language and other cultural and historical factors, such comparative field research as his provides valuable and meaningful insights. After describing sharp differences between the two areas in terms of geological strata and aquifer distribution, in addition to the water balance for rice production, Sato suggests that government intervention for promoting sustainable agriculture must be designed with full consideration of the hydrological characteristics of each area.

As discussed here, the key policy intervention needed to solve the foodwater-energy nexus is found in the power sector. From the 1990s, the World Bank and other donors tried to engage in power sector reforms in several states in India, largely in vain. The main reason for this failure is that agricultural power tariffs are a very sensitive political issue. More recently, however, some state governments have successfully implemented bold power tariff reforms. Gujarat and West Bengal are examples of such successful cases. Shah and Chowdhury (Chapter 11, 'Farm Power Policies and Groundwater Markets: Contrasting Gujarat with West Bengal (1990-2015)') specifically examine the effects of such power sector reforms on the functioning of groundwater markets at a local level by comparing the cases of Gujarat and West Bengal. In Gujarat, an innovative power sector reform program (called Jotigram Yojona) was launched (Shah and Verma, 2008). The West Bengal state government, on the other hand, introduced a metering system for agriculture in place of the flat-tariff while abolishing the electric tube well permit system. Consequently, however, the groundwater markets shrunk and/or the water charges paid by less resourceful farmers to the well owners increased in both cases. Those results imply that 
the power sector reforms, although contributing to reduction of the nexus difficulties, produced severe ill effects for farmers in weaker market positions.

As described above, the chapters of this book address various important issues related to Indian (and South Asian) agricultural development in the past and in the present while more or less centering upon the food-waterenergy nexus. Editors and authors of the book welcome comments and arguments that will lead to fruitful discussions about the future of India and South Asia.

The chapters included in this book were first presented as papers at an international conference (The Eighth INDAS International Conference 'Toward Sustainable Development of India and South Asia' held in Kyoto, Japan on 17-18 November, 2017). The conference was organized with financial support from the National Institute of Humanities (NIHU), Tokyo, for which the editors and contributors are grateful.

\section{Notes}

1 Although energy issues, especially in terms of fossil energy, became important only relatively recently, the introduction of wells serviced with diesel engines and electric motors started towards the end of the nineteenth century in South Asia.

2 By artificially cutting river banks, the seasonally-heightened river water flows out to the surrounding farmland, making it useful for crop cultivation. The most famous example of inundation irrigation was that of the lower basin of the Indus (Johnson, 1979b). Willcocks (1930) also emphasized the importance of inundation irrigation, which he called overflow irrigation, in Bengal in terms of supplying water, manure, and killing mosquitoes as well.

3 Johnson (1979a) also describes the agro-ecological environments and irrigation technologies in India.

4 Doon and swing basket were most widely used in eastern India, especially in eastern Bengal (now Bangladesh).

5 Another type of tank called ahar is used in southern Bihar. An ahar is a water harvesting structure with rectangular embankments. The ahar water is supplied either through a canal (pyne) in the case of ahar-pyne or by natural drainage after rainfall in the case of rainfed ahar. The ahars differ from regular tanks in that the bed of an ahar is not dug; also, usual tanks do not have a raised embankment of an ahar (Koul et al., 2012). See Chapter 6 of this book.

6 As suggested in footnote 2 of Table 1.1, if the statistics of net irrigated area in West Bengal are corrected, the share of well irrigation becomes even larger than 62 percent.

7 Traditional irrigation devices, aside from their inefficiency in drawing water from wells, became inoperative when the depth to the water table sank below a certain limit: about 15 feet in the case of human-operated devices, 35 feet in the case of an animal-operated Persian wheel, and about 50 feet in the case of the animal-drawn mhot (Dawan, 1986: 88).

8 The role of the economic liberalization policies is usually emphasized to explain the rapid and sustained economic growth in India since 1991, but we emphasize the crucially important role of the agricultural growth and associated rural poverty reduction during the 1980 s. 
9 It is often asserted that, despite the dramatic improvement of food supplydemand balance after the mid-1990s, India's malnutrition problem is still comparable to those of Sub-Saharan African countries. However, Panagaria (2012) presents a critique against such views.

10 It is noteworthy, however, that Pakistan (in the two major provinces of Punjab and Sindh) is an exception because the government abandoned the flat tariff in 2000 .

11 The eastern half of the subcontinent not only failed to benefit from the power subsidy, but also suffered from the price hike of diesel oils, especially since the 1990s, which resulted in the slower progress or even decline of well irrigation.

12 Note here also an important institutional factor which retarded the agricultural development in Bengal after the disappearance of the land frontier: the highly stratified rural society which emerged in the Sundarbans in its development process, as argued by Taniguchi, was transformed considerably after Independence by a series of institutional reforms, including the abolition of zamindars and other intermediaries in the 1950s, the land reforms in West Bengal following 1977, etc. - although in the case of Bangladesh, migration of upper-class Hindu people to West Bengal after the Partition contributed greatly to reduce the problem.

13 In a strict sense, Tamil Nadu is situated in the eastern half, but because of its proximity to the Western Ghats Mountains, the southwestern monsoon is blocked by the mountains. Therefore the state is quite dry.

14 Although the contribution of Punjab in the national food pool (government procurement) has declined in recent years, in 2014-15 it was still 24.2 percent for rice and 41.5 percent for wheat (Government of India, 2016).

15 Major reports of the literature include the following: Shah et al. (2006), Mukherji (2007), Mukherji et al. (2009), Shah (2009), Shah et al. (2012), and Kumar et al. (2014).

\section{References}

Dakshinamurti, C., A. M. Michael and S. Mohan (1973). Water Resources of India and Their Utilization in Agriculture, Delhi: Water Technological Center, Indian Agricultural Research Institute.

Dawan, B. D. (1986). Economics of Groundwater Irrigation in Hard Rock Regions: With Special Reference to Maharashtra State, New Delhi: Agricole Publishing Academy.

Fujita, K. (2015). "Dokuritsugo Indo no Keizai Hatten Keiro" [in Japanese: Economic Development Path of India after Independence], In Tanabe, A. et al. ed., Gendai Indo 1: Tayosei Syakai no Chosen [in Japanese: Modern India vol. 1 - Challenges of Diversified Society], Tokyo: Tokyo Daigaku Syuppankai [The University of Tokyo Press], pp. 279-303.

Government of India (Ministry of Agriculture and Farmers Welfare) (2016). Agricultural Statistics at a Glance 2015, New Delhi: Ministry of Agriculture and Farmers Welfare, Government of India.

Hayami, Y. (1986). Nogyo Keizairon [in Japanese: Agricultural Economics], Tokyo: Iwanami Syoten.

Islam, M. M. (1997). Irrigation, Agriculture and the Raj, Punjab, 1887-1947, New Delhi: Manohar Books.

Johnson, B. L. C. (1979a). India, London: Heinemann Educational Books Ltd.

Johnson, B. L. C. (1979b). Pakistan, London: Heinemann Educational Books Ltd. 
Koul, D. N., S. Singh, G. Neelam and G. Shukla (2012). "Traditional Water Management Systems: An Overview of Ahar-pyne System in South Bihar Plains of India and Need for Its Revival," Indian Journal of Traditional Knowledge, vol. 11 (2), pp. 266-72.

Kumar, M. D., N. Bassi, A. Narayanamoorthy and M. V. K. Sivamohan (2014). The Water, Energy and Food Security Nexus: Lessons from India for Development, London/New York: Routledge.

Mosse, D. (2003). The Rule of Water: Statecraft, Ecology, and Collective Action in South India, New Delhi: Oxford University Press.

Mukherji, A. (2007). "The Energy-Irrigation Nexus and Its Impact on Groundwater Markets in Eastern Indo-Gangetic Basin: Evidence from West Bengal, India," Energy Policy, vol. 35, pp. 6413-30.

Mukherji, A., K. G. Villholth, B. R. Sharma and J. Wang (2009). Groundwater Governance in the Indo-Gangetic and Yellow River Basins: Realities and Challenges, London: CRC Press.

Muniandi, J. and K. Fujita (2011). "Deterioration of the Informal Tank Institution in Tamil Nadu: Caste-Based Rural Society and Rapid Economic Development in India,” Tonan Ajia Kenkyu (Southeast Asian Studies), vol. 49 (1), pp. 93-123.

Palanisami, K. (2000). Tank Irrigation: Revival for Prosperity, New Delhi: Asian Publication Services.

Palanisami, K. and R. Balasubramanian (1998). "Common Property and Private Property: Tank vs. Private Wells in Tamil Nadu," Indian Journal of Agricultural Economics, vol. 53 (4), pp. 600-13.

Palanisami, K. and K. W. Easter (2000). Tank Irrigation in the 21st Century: What Next? New Delhi: Discovery Publishing House.

Panagaria, A. (2012). The Myth of Child Malnutrition in India, paper presented at the conference "India: Reforms, Economic Transformation and the Social Disadvantaged" held at Columbia University in September 2012.

Rogaly, B., B. Harris-White and S. Bose ed. (1999). Sonar Bangla? Agricultural Growth and Agrarian Change in West Bengal and Bangladesh, Dhaka: The University Press Limited.

Sato, T. and P. R. Duraiyappan (2011). "The Effects of Expansion of Private Wells on Rural Livelihood in Tank Intensive Watersheds: A Case Study in Upper Gundar River Basin, Tamil Nadu," Tonan Ajia Kenkyu (Southeast Asian Studies), vol. 49 (1), pp. 124-50.

Shah, T. (1993). Groundwater Markets and Irrigation Development, Bombay: Oxford University Press.

Shah, T. (2009). Taming the Anarchy: Groundwater Governance in South Asia, Washington DC: Routledge.

Shah, T., M. Giordano and A. Mukherji (2012). "Political Economy of the EnergyGroundwater Nexus in India: Exploring Issues and Assessing Policy Options," Hydrogeology Journal, vol. 20, pp. 995-1006.

Shah, T., O. P. Singh and A. Mukherji (2006). "Some Aspects of South Asia's Groundwater Irrigation Economy: Analysis from a Survey in India, Pakistan, Nepal Terai and Bangladesh," Hydrogeology Journal, vol. 14, pp. 286-309.

Shah, T. and S. Verma (2008). "Co-management of Electricity and Groundwater: An Assessment of Gujarat's Jotigram Scheme,” Economic and Political Weekly, vol. 43 (7), pp. 59-66. 
16 Koichi Fujita and Tsukasa Mizushima

Tada, H. (1992). Indo no Daichi to Mizu [in Japanese: Land and Water in India], Tokyo: Nihon Keizai Hyoronsya.

Takaya, K. (1985). Tonan Ajia no Shizen to Tochi Riyo [in Japanese: Nature and Land Use in Southeast Asia], Tokyo: Keiso Syobo.

United Nations Development Program (UNDP) (2016). Human Development Report 2016, New York: United Nations Development Program.

Willcocks, W. (1930). Lectures on the Ancient System of Irrigation in Bengal and Its Application to Modern Problems, Calcutta: University of Calcutta. 


\section{Part I}

\section{Land, water, and population in the past and future}


$\because$ Taylor \& Francis

Taylor \& Francis Group

http://taylorandfrancis.com 


\title{
2 Land development and demographic change in Tamil Nadu from the late eighteenth to the early twentieth century*
}

\author{
Tsukasa Mizushima
}

PROFESSOR EMERITUS, THE UNIVERSITY OF TOKYO

\section{Introduction}

South India was transformed from a sparsely populated to a densely populated region during British colonial rule. Two harsh famines in the late nineteenth century and influenza outbreaks in the late 1910s left the area with many deaths and much illness, but the population more or less continued to increase until 1920, when the region entered an explosive growth period.

Despite climatic and environmental extremes in addition to perennial cycles of excesses and deficiencies, India has been home to one-fifth to onequarter of the world total population for many centuries (Maddison, 2009). Moreover, the society has always had a large proportion of its population engaged in non-agricultural sectors. An analysis of the Barnard Records, or village accounts covering more than 2,000 hamlets ${ }^{1}$ of the Jagir (later Chingleput, a district surrounding Madras) in the late 1770s, reveals that the share of the population employed in non-agricultural sectors was nearly half. Nevertheless, the hamlets remained small, as did their numbers of inhabitants. How can we interpret these seemingly contradictory and definitely complex situations in the early modern period?

This chapter presents an attempt at disentangling those difficulties by exploring the historical development of agriculture, demographic change, and social transformation in South India from the late eighteenth century to the early twentieth century. ${ }^{2}$

\section{Pre-colonial system}

How could such a sparsely populated and low-productivity society as South India in the pre-colonial period support a large proportion of nonagriculturists? Two factors must be considered. First is the concentration of agricultural operations in favorable locations, which enabled high productivity. Second is the flexibility of the mirasi system, which was able to compensate for highly fluctuating agricultural conditions. We will investigate these two factors first. 


\section{Tsukasa Mizushima}

Regarding the first point, one must consider the population sizes of the respective hamlets. The average hamlet was as small as 135 inhabitants of 29 houses, according to village records with information covering around 2,300 hamlets in Chingleput prepared at the beginning of the nineteenth century. ${ }^{3}$ Given the ever-fluctuating and insufficient quantities of annual rainfall of $300-500 \mathrm{~mm}$ (Figure 2.1), the necessary size of the hamlet for survival is determined fundamentally by water resource availability. Except for those located in deltas such as Tanjavur in Tamil Nadu or Godavari in Andhra Pradesh, most hamlets depended upon tanks constructed for irrigational purposes in the past. The same village records show that 2,381 tanks existed. Most hamlets had one or two. Judging from those records, a tank or two was apparently the necessary condition that enabled people to survive by operating stable agriculture. Although many tanks have immense surface area in rainy seasons, their depths are too shallow to maintain irrigation for more than a few months. People took only those land spots with irrigational facilities by tanks and maintained stable agriculture in these limited spots. The key to maintaining a large population that included a considerable number of non-agriculturists was high productivity on the irrigated land with a small population dependent upon it.

Regarding the second point, the flexibility of the mirasi system, one must recognize fundamental differences between the mirasi system and the colonial land system (Kotani et al., 2008). First, it should be described that many contemporary records of the Madras Presidency and some other parts of India include references to the prevalence of the mirasi system, although the system was variously referred to as vatan, or kani, amongst other terms. A detailed description of the mirasi system has been presented in the literature (Mizushima, 2006 \& 2014b). For that reason, only a very brief description is presented hereinafter.

Under the mirasi system, everyone and every institution in the locality was entitled to some proportional share of the local produce in exchange for performing some assigned role in reproducing the local society. The Barnard Records of the 1770s and many other colonial records kept from the late eighteenth century present detailed accounts demonstrating that every hamlet had a sophisticated system of dividing all local produce into many shares. Humans such as government servants, military chiefs, smiths, washermen, barbers, and priests, and institutions such as the state, temples, and mosques were, respectively, allocated proportional shares. The allocation of proportional shares in the mirasi system was highly flexible because it was readily adjustable to historical or temporal changes. For example, if some new occupation was created in the locality, then the system might allocate some new share from the total of the produce. As indicated also by the lists of recipients, most people engaged in non-agricultural occupations received shares as well. ${ }^{4}$ Regarding the unit of production, it seems possible that a few dozen hamlets constituted a basic unit. If we regard the hamlet 


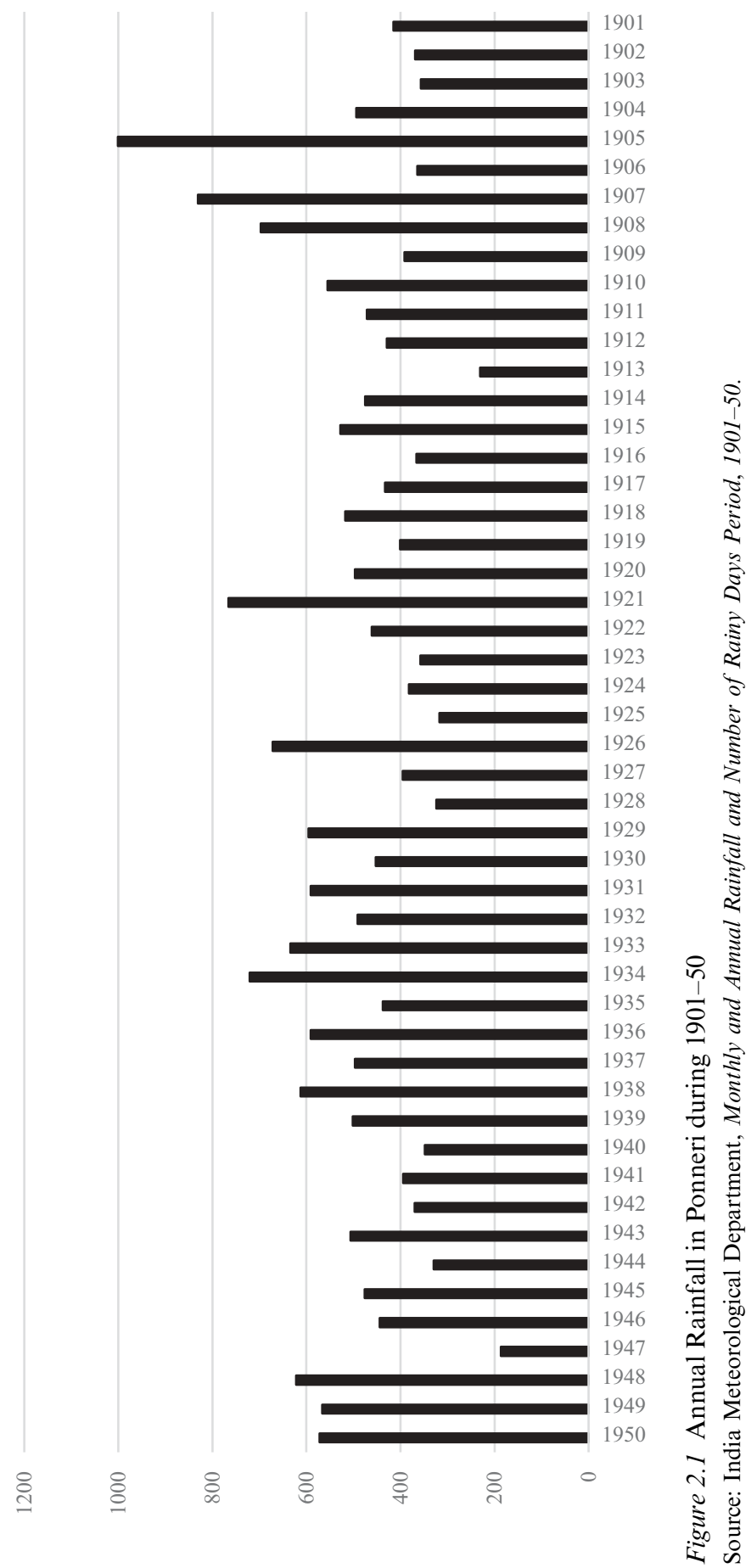




\section{Tsukasa Mizushima}

population as very small, then it was impossible to sustain the entire reproduction system solely by the efforts of the respective hamlets. ${ }^{5}$

One important aspect related to the mirasi system flexibility was its function as a sort of social security system. Considerable disparity existed in the share proportions allocated to the respective recipients, but one can observe that the system provided a sort of social security to the lowest class of people. Even when scarcity of food occurred in bad years, everyone in the system could at least expect a certain amount of produce from the collective product of the locality. The importance of this aspect becomes quite clear if one considers that it would become impossible if the societal unit maintaining the mirasi system were to fracture, with the local populace dissolved into many units. That social fracturing actually occurred during the colonial period, as described below.

Consequently, seemingly contradictory circumstances including the small hamlet populations, sparse distribution of people, considerably large proportions of non-agriculturalists, large total population, and the sustained production in the pre-colonial period can be understood in this context.

What occurred with the mirasi system during the colonial period? What were the effects of the colonial land policy, especially the raiyatwari settlement introduced into the Madras Presidency at the beginning of the nineteenth century? We investigate those issues next.

\section{From pre-colonial system to colonial system}

In contrast to the pre-colonial period, when the mirasi system functioned in reproducing local society as a whole, colonial lands defined each land lot as the basic unit for production. The landholders, called pattadars, thereby became exclusive holders of the respective land lots. ${ }^{6}$

Under the raiyatwari land administration, those who were initially granted exclusive landholding in the respective villages were often the village landlords. These village landlords, called mirasidars in the contemporary practice, were recorded in the colonial records. In the pre-colonial period, each village was controlled exclusively by a certain number of mirasidars, mainly comprised for members of one or two castes. Under the raiyatwari system, land was often allocated exclusively to these mirasidars or to their fellow caste members.

The situation of land allocation to a single caste can be verified based on results of a case study of RM village in Trichinopoly district. An investigation into the percentage of landholding held by the respective castes in RM in 2008 with a study of land registers and field interviews indicates that the landholdings were widely spread across several castes including 'the untouchables' (Table 2.1). Calculation from the oldest land registers, by contrast, reveals that the Reddiyar caste, composed of mirasidars, occupied almost 80 percent of the land in 1864. Since then, their dominant position 
Table 2.1 Landholding by Caste in RM between 1864 and 2008

\begin{tabular}{lccccr}
\hline & 1864 & 1898 & 1924 & 1982 & 2008 \\
\hline Caste in RM & $\%$ & $\%$ & $\%$ & $\%$ & \multicolumn{1}{c}{$\%$} \\
Asari & 1.3 & 1.6 & 0.7 & 0.9 & 0.9 \\
Bramin & 0.0 & 0.0 & 0.1 & 0.0 & 0.0 \\
Chettiyar & 0.0 & 0.0 & 1.1 & 1.8 & 0.3 \\
Christian & 0.2 & 3.3 & 4.5 & 5.2 & 5.8 \\
Christian-Paraiyan & & & & & 1.1 \\
Gounder & 0.2 & 2.0 & 11.5 & 18.4 & 22.9 \\
Kuravar & & & & & 0.0 \\
Muslim & 1.9 & 0.7 & 2.8 & 2.0 & 3.2 \\
Muthuraja & 7.7 & 16.8 & 16.0 & 22.1 & 26.1 \\
Nasuvan & & & & & 0.0 \\
Ottan & 0.0 & 0.6 & 0.0 & 0.5 & 1.7 \\
Pallan & 0.3 & 1.3 & 3.5 & 4.3 & 4.0 \\
Pandaram & 0.4 & 0.0 & 0.3 & 0.2 & 0.0 \\
Paraiyan & 0.2 & 2.8 & 5.7 & 5.9 & 2.5 \\
Reddiyar & 77.6 & 60.3 & 40.6 & 26.9 & 23.2 \\
Sakkiliyan & 0.1 & 1.1 & 3.2 & 3.6 & 4.9 \\
Udaiyar & 2.0 & 4.2 & 7.1 & 7.5 & 3.0 \\
Vannan & 0.0 & 0.5 & 0.3 & 0.1 & 0.0 \\
Vanniya Chettiyar & & & & & 0.1 \\
Vanniyar & & 0.0 & 0.2 & 0.3 & 0.0 \\
Viswakarma & & & & & 0.3 \\
& & 100.0 & 100.0 & 100.0 & 100.0 \\
\hline & & & & &
\end{tabular}

Source: Settlement Registers, 1864, 1894, 1924, and field surveys in 1982-83 and 2007-08.

was reduced greatly every 30 years until recently, when they accounted for less than a quarter of registered landholdings. If one extends this historical trend back to the early nineteenth century, when the raiyatwari system was first introduced, then one might conclude that they were the exclusive landholders at the start of the colonial land system.

\section{Progress of land reclamation during early colonial rule}

Landlords, or the former mirasidars, who secured a dominant share of landholding in the raiyatwari system, tried to the greatest possible degree to restrict others from occupying land. In sparsely populated areas, labor was often much more important than land. It was necessary for landlords to exclude others from landholding to secure their labor. In contrast, those who were excluded from landholding in the colonial system also lost their 
customary rights, i.e., their share in the local produce previously allocated in the mirasi system. They now desperately needed land for survival. Consequently, severe conflicts erupted between the landholders and nonlandholders. Many court cases followed during the period.

The colonial government had to accelerate cultivation to maximize the land revenue. What prevented government efforts was the claim of the mirasidars, who maintained that they had ownership over all village territory. For extension of the cultivated area, it was imperative for the government to break their control over all village resources, especially the uncultivated land, and to compel the non-mirasidars to occupy them for cultivation. That was never an easy task. The colonial government withstood decades of resistance from the mirasidars.

We next examine the processes of land administration in Chingleput. The actual processes were pursued through trial and error. ${ }^{7}$ Dittam, swatantram, pangu, and darkhast were the main attempts by the colonial government to seek a solution.

In the dittam system, mirasidars' lands cultivated by the payakari (nonmirasidar cultivators working under the mirasidars) were to be registered under the chief mirasidar's name. The payakaris' names were not registered in the patta (land title). The payakaris paid landlord rents (swatantram) to the mirasidar. Mirasidars also had pre-emptive rights to obtain unoccupied land whenever payakaris applied for its holding. In short, the government acknowledged mirasidars as landlords together with the mirasidars' territorial claim over the entire village. This recognition constituted a deviation from the principle of the raiyatwari system based on the premise of the state as the exclusive land owner. Behind this deviation lay the latent power of mirasidars in the contemporary period. By sending numerous petitions to the head office of the revenue department in Madras or by deserting to other areas to paralyze revenue collection, mirasidars resisted the colonial government attempts to deprive them of their power.

It was nevertheless imperative for the Board of Revenue to increase land revenues by making people take up unoccupied land. In 1834, the Board sent out a circular. It ordered revenue officers to bring payakaris into landholdings of unoccupied land on the condition it would not infringe on the mirasidars' interests. Despite strong resistance by mirasidars, payakaris were able to acquire land to an increasing degree. However, when these cases became too frequent, the Board of Revenue sent another circular in 1843. This time it completely banned land grants to payakaris against the will of mirasidars.

A change of policy occurred again in 1856. The Board of Revenue abolished the dittam system and instead introduced the pangu system, which divided village lands according to the respective share (pangu) of mirasidars and registered the divided lands as independent holdings. The new system succeeded in dissolving the base of ties among the mirasidars to control 
entire villages against non-mirasidars. Another feature of the pangu system was to collect land taxes of all landholdings, even if some lands were not cultivated. Formerly, mirasidars registered land ownership to prevent payakaris from acquiring land. They later abandoned the land to escape revenue collection. Introduction of the pangu system succeeded in preventing such nominal land registration by mirasidars and widened the opportunities of payakaris to acquire land.

Two additional changes occurred respectively in 1863 and 1869. Throughout the Madras Presidency, a new rule called darkhast was introduced in 1863. The rule specified that when someone applied to obtain unoccupied land, a public notice must be posted for 30 days. During that period, anyone claiming a pre-emptive right to the applied land would be able to verify it. In 1869 another darkhast rule applicable only to Chingleput was added. Now, those who wanted to nullify the darkhast application by others had to make a claim and had to propose acquisition of the land within 30 days. The order of priority was first to mirasidars and second to payakaris having patta. When a payakari obtained land, an individual patta was to be issued to him. Consequently, the darkhast rule imposed many procedures upon mirasidars to protect their territorial rights over the entire village against payakaris.

After all these government attempts were made, what was left to the mirasidars was first to receive landlord rent at the rate of two annas per rupee of land assessment from the non-mirasidar cultivators of their land. In the case of lands for which the landlord rent had never been paid to mirasidars and in cases where non-mirasidars acquired land, the latter were acknowledged as landholders. In case these lands came to be abandoned and nonmirasidars took them up again, they had to pay the landlord rent to mirasidars.

In 1870, the mirasidars were dealt another blow. The state abolished compensation to the mirasidars for the requisition of unoccupied land for public purposes. $^{8}$ The state's land ownership now became absolute and exclusive. It superseded the mirasidars' landlord rights.

In contrast to the decline of mirasidars' power, the opportunities of land acquisition by payakaris naturally increased. The value of the landlord's rent allocated to the mirasidars became less and less important because of increasing agricultural prices in the latter half of the nineteenth century.

By 1877, when re-settlement was conducted in Chingleput, the result of the policies in the past decades had become apparent. After the competitive struggles among these three players, the power of the mirasidars to control the entire village territory, and the interest accrued from that power, were greatly reduced. ${ }^{9}$ Lands not yet occupied came to be freed from their control and given for development by others. The oligarchical landholding structure created at the beginning of the nineteenth century was broken in many of the villages, too. 


\section{Tsukasa Mizushima}

It might be added that the process was advanced by the declining power of the mirasidars, and also by colonial economic development. Compared to opportunities in local agriculture, better opportunities in Madras and other urban areas lured village landlords into out-migration. First moved the Brahmins. They were followed by non-Brahmin landlords. Their lands in the native villages were eventually passed to the remainder of the villagers, including non-landholders.

Although one important result from these changes was the extension of cultivation in the old established area, we also found rapid progress of land reclamation in peripheral areas that had never been inhabited previously. By fixing lower tax rates in these untouched peripheral areas, the government also anticipated land reclamation. During the nineteenth century, waves of land reclamation did occur. The extent of land development both in the old and new areas is readily apparent when comparing Map 2.1 and Map 2.2, respectively showing cultivated areas of respective hamlets in 1801 and 1871. The respective ratios of mirasidar and non-mirasidar landholdings in 1877 are also portrayed in Map 2.3. In the old villages where mirasidars did exist, their share had become only 41 percent. If the newly developed peripheral areas that did not have mirasidars previously are included, then the total percentage owned by the mirasidars was as low as 28 percent of all landholdings. These maps reflect the transformation of society.

These newly opened lands, however, did not promise stable agriculture. They remained untouched because of their harsh conditions for agricultural production. As described above, the scarcity of irrigation water in the tanks did not allow many hamlets to sustain a large population during the precolonial period. The same condition continued into the colonial period. The newly opened land both in the old established area and in the newly opened virgin area presented the same difficulty. Even so, the desperate need of many people for land acquisition had already pushed cultivation to the periphery during the nineteenth century. The progress of such land development coupled with rapid population growth deepened the vulnerability of agricultural production and of society at large. We examine that process and its effects next.

\section{Population increase in the pre-census period}

Land development from the beginning of the nineteenth century progressed concomitantly with high population growth. In fact, India has no reliable information related to population change before 1871 or the pre-Census period. Important resources to ascertain the situation of population at the beginning of the nineteenth century are village accounts prepared at the time of the Permanent Settlement in 1801 in Chingleput. Comparison of hamlet populations with village-level statistics of the 1871 Census shows the overall population change in around 2,300 hamlets. An analysis of them leads us to infer that rapid population growth occurred between 1801-71. 


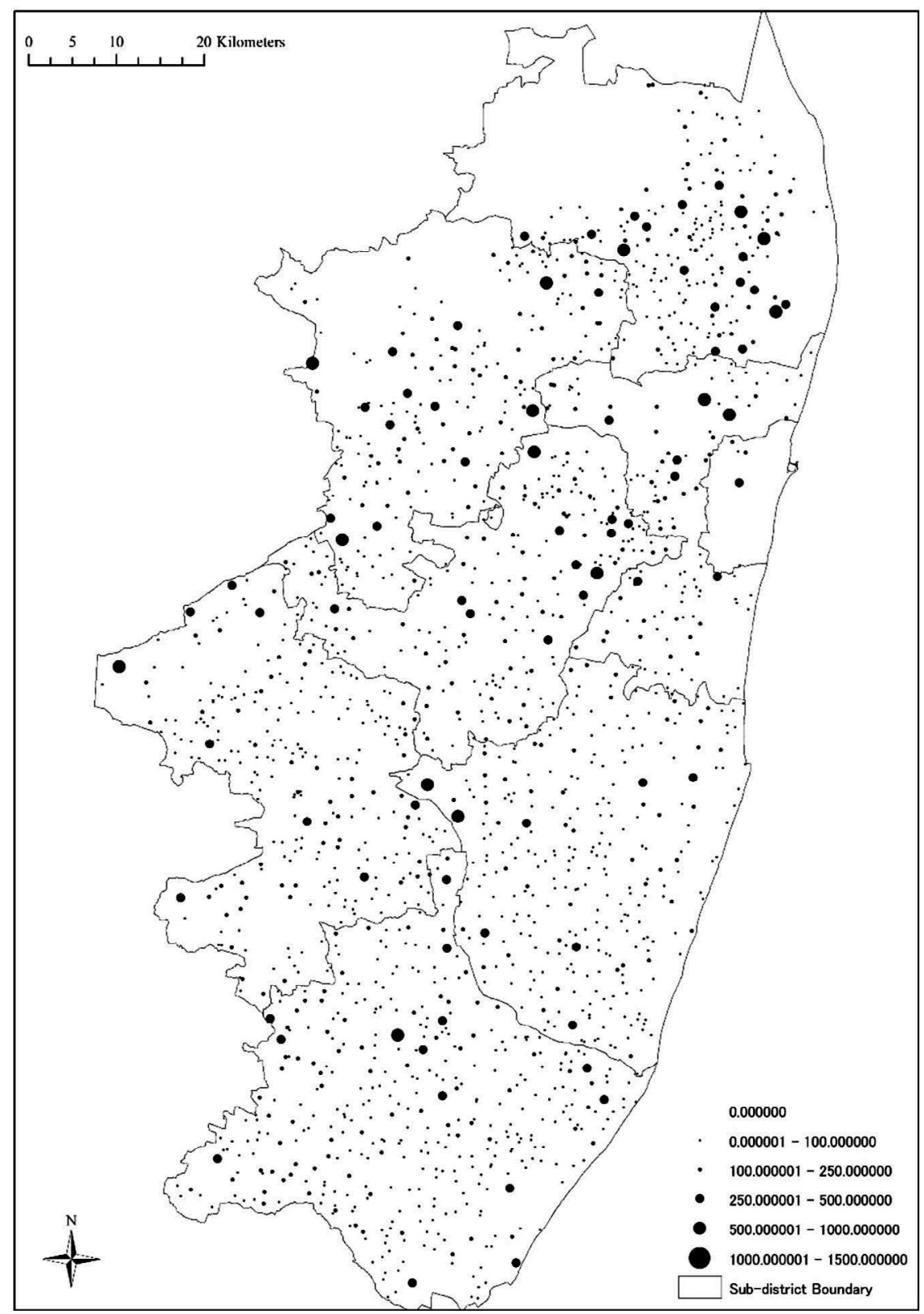

Map 2.1 Cultivated Land in Chingleput in 1801

Source: Zamindari Statement, Statement relating to Permanent Settlement of Jagir forwarded as Enclosures to Mr. Greenway's Letter, 29 March, 1801 (Permanent Settlement Records, vols. 20-22) 


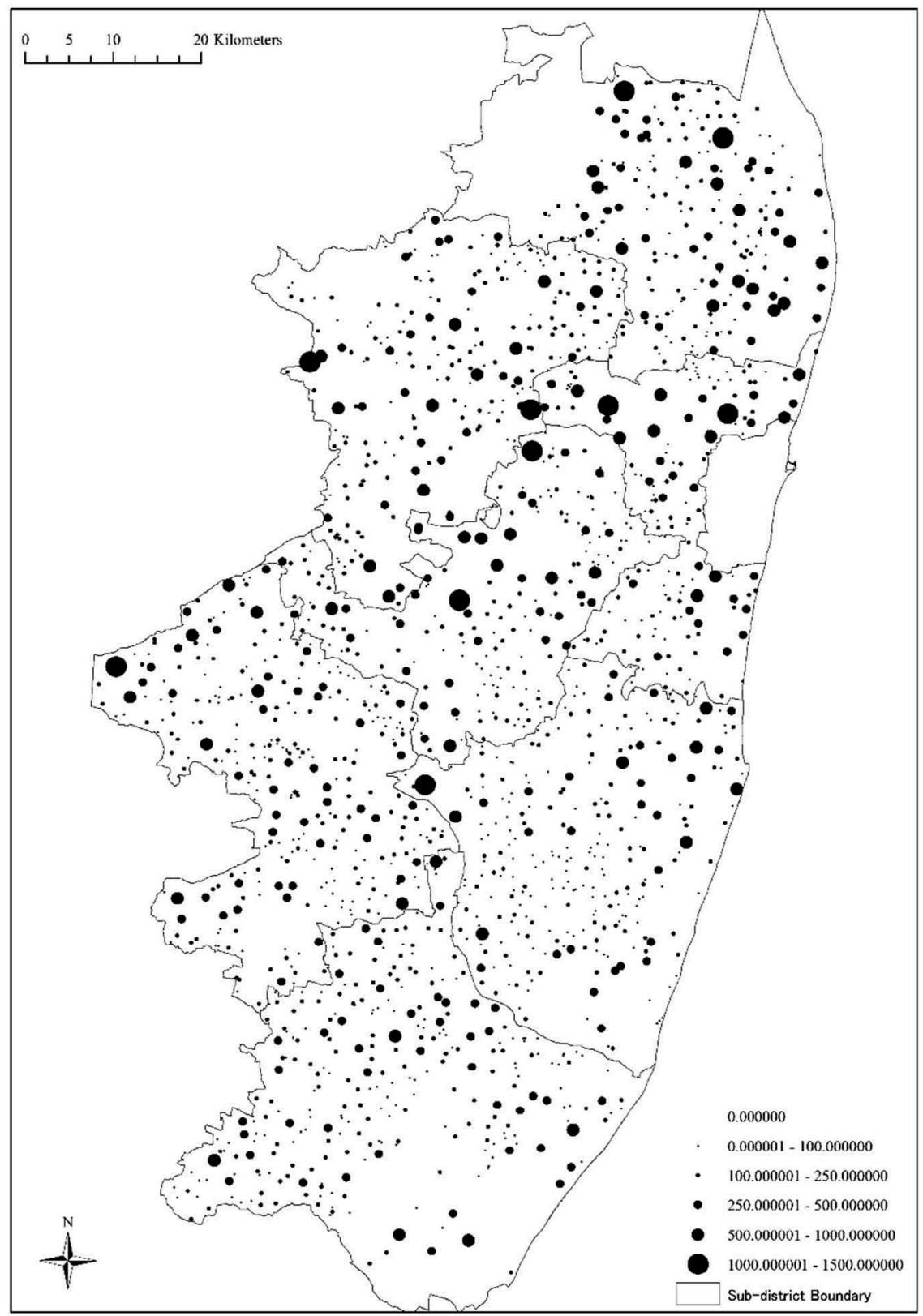

Map 2.2 Cultivated Land in Chingleput in 1871

Source: Census, Statement of Population of 1871 in Each Village of the Chingleput District arranged according to Area, Caste, and Occupation, Madras, 1874. 


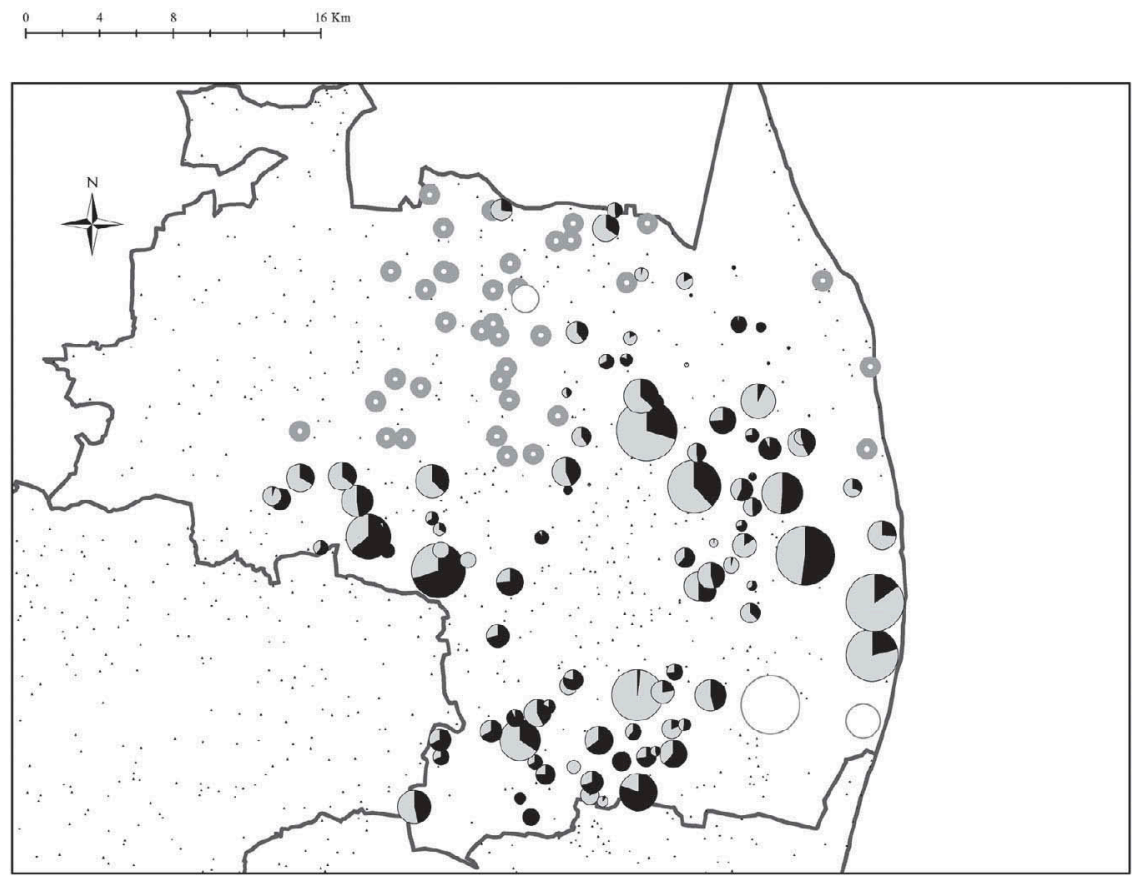

Notes.

- Landholding by Mirasidars

$\square$ - Landholding by Non-Mirasidar

- Data not available

- Non-Mirasi Villages

Map 2.3 Composition of Mirasidar and Non-Mirasidar Landholding in Ponneri Villages Source: Settlement Registers of Ponneri Villages in 1877

The number of households increased from 52,785 to 135,985 (258 percent increase), whereas the population increased from 244,845 to 941,047 (384 percent increase). A comparison of Maps 2.4 and 2.5 clarifies the change.

The unexpectedly high rate of population increase in Chingleput might lead one to suspect that Chingleput was exceptional because of its proximity to Madras, the capital of the Madras Presidency. However, an investigation into the decadal demographic changes of all the districts in Tamil Nadu between 1801 and 1901 demonstrates that such was not the case, as indicated in Figure 2.2. Many districts of South India showed a similar trend of 


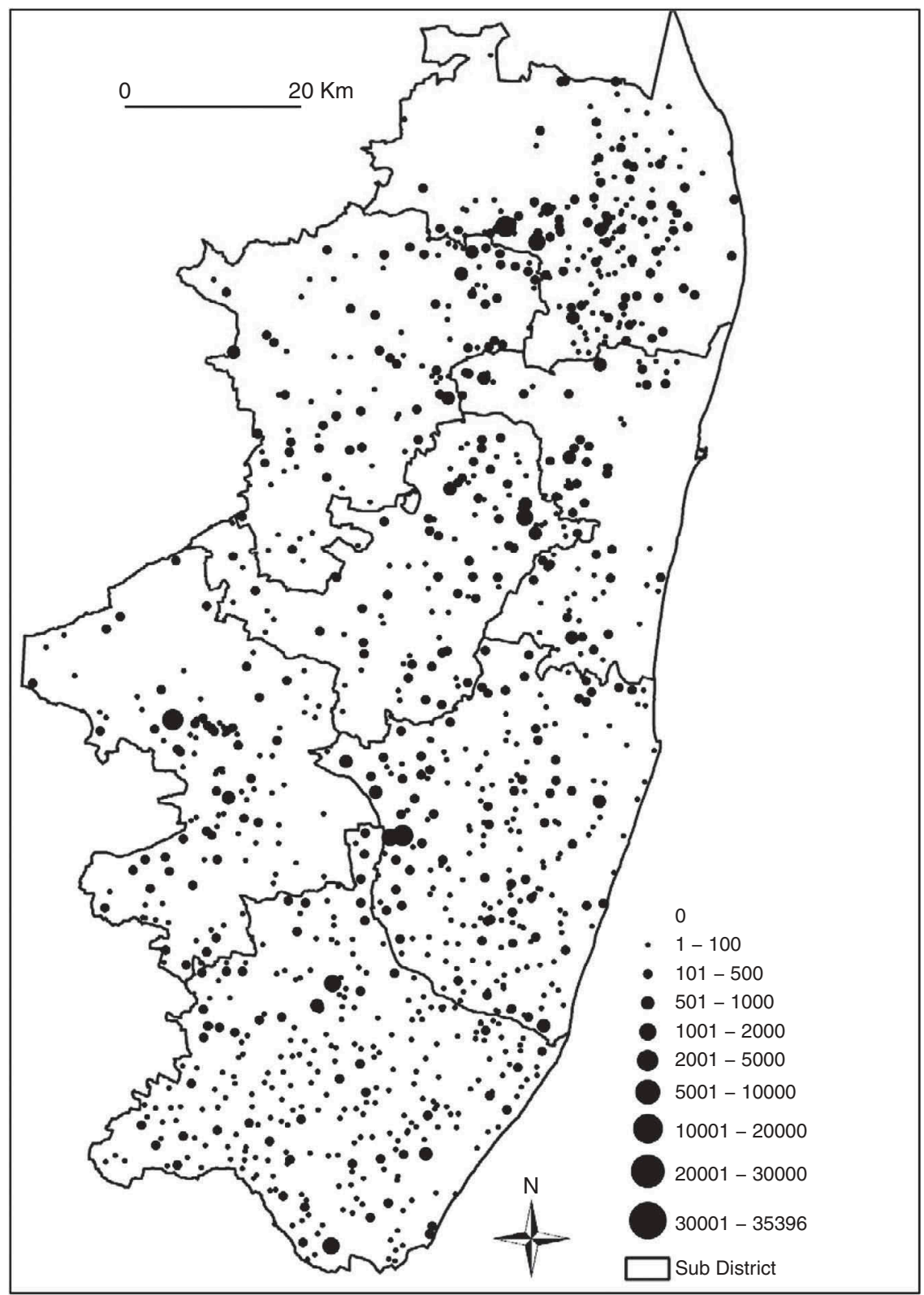

Map 2.4 Populations of Hamlets in Chingleput in 1801

Source: Zamindari Statement, Statement relating to Permanent Settlement of Jagir forwarded as Enclosures to Mr. Greenway's Letter, 29 March, 1801 (Permanent Settlement Records, vols. 20-22) 


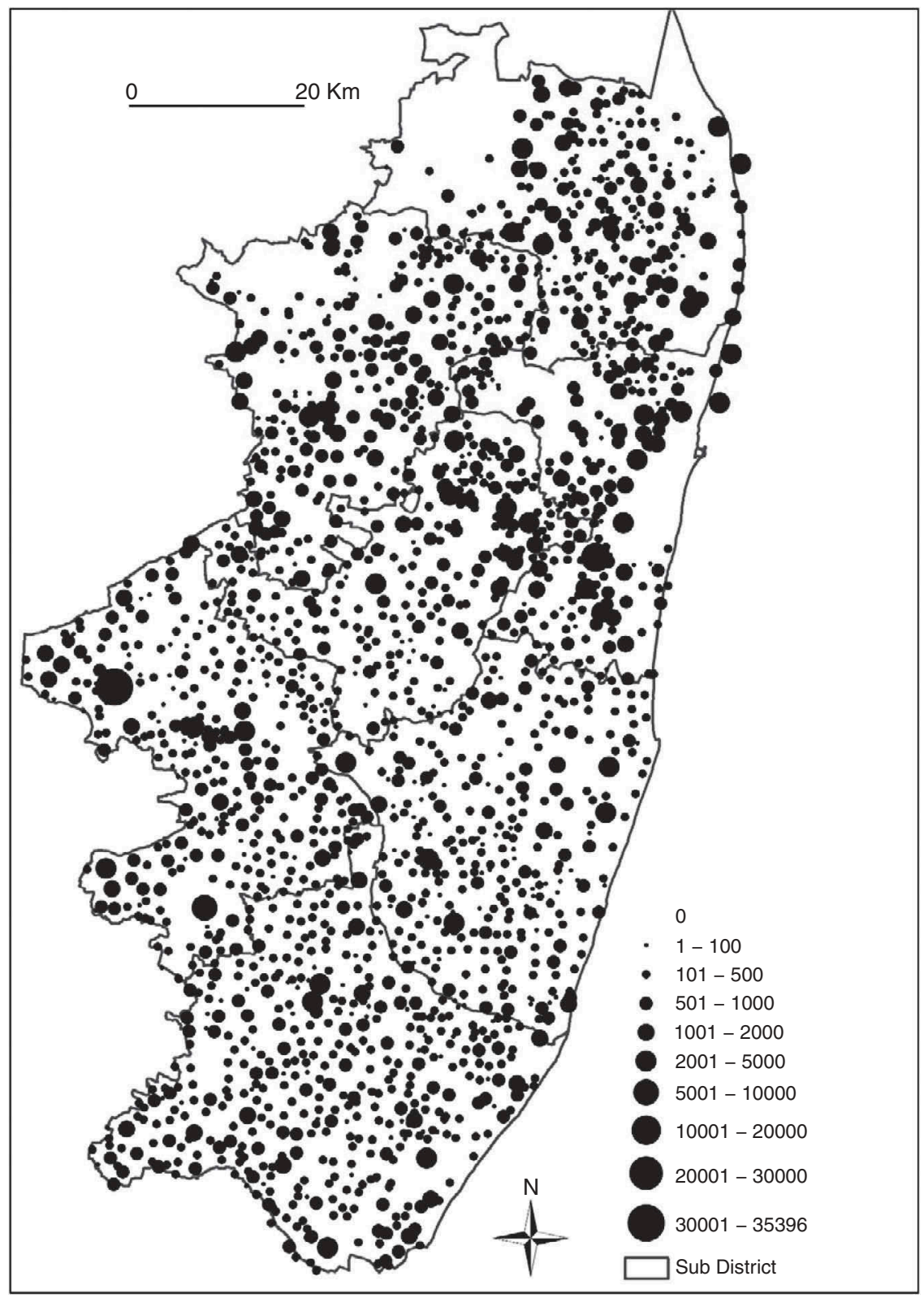

Map 2.5 Populations of Hamlets in Chingleput in 1871

Source: Census, Statement of Population of 1871 in Each Village of the Chingleput District arranged according to Area, Caste, and Occupation, Madras, 1874. 


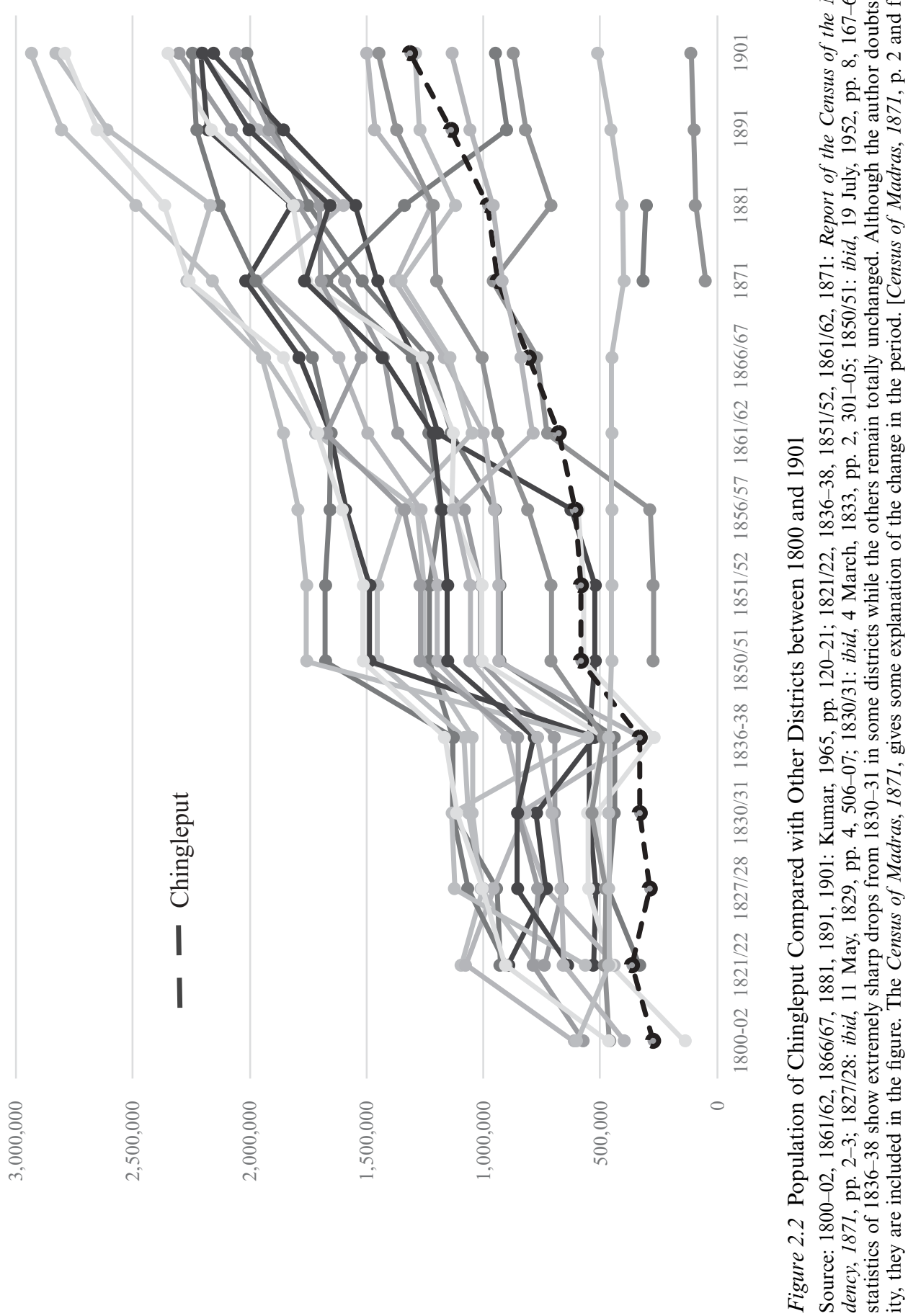


increase. Rapid population growth took place in the pre-Census period in South India.

Although the difference of regional population growth rates summarized by Guha is described as a 'guesstimate' (Guha, 2001), the implications of that difference might be examined. The increase rate of South India between 1800 and 1881 was 113 percent, which was much higher than the rates of other parts of India such as North India (26 percent), Central India (51 percent), West India (58 percent) and East India (96 percent), during the pre-Census period (Guha, 2001: 58, Table 1.4). As indicated by Map 2.6, which presents the rate of population increase between 1881 and 1901 by region, the early Census period in the late nineteenth century also shows a higher rate of increase. In short, land and population seemed to develop along similar lines in South India.

\section{Famine and recovery}

As discussed up to this point, South India experienced not only demographic and agricultural changes, but also societal changes defined by social and environmental development starting from the early nineteenth century. Related changes included the collapse of the mirasi system, the rapid population growth in the pre-Census period, and increasing instability caused by the extension of cultivation into the periphery ${ }^{10}$. This section presents a specific examination of the growing insecurity of lower classes of people who were unable to afford to acquire land under the colonial land system.

Cut from the security system formerly maintained using the mirasi system, people of the lower classes tried with great difficulty to survive, but failed to do so, especially during times of severe climatic conditions. Violent climatic fluctuations that struck South India in the late 1870s and 1890s left millions of victims. Without support under the mirasi system, however meager it was, they were compelled to leave their villages to seek opportunities that were provided only narrowly by the government. The two famines of the late nineteenth century were actual proof of the growing vulnerability of society against calamities after decades of hasty extension of cultivation and steep demographic change.

South Indian society, however, started recovery from the late nineteenth century. After seeing the limits of further extension of land development around the turn of the century, they sought alternatives and found a more reliable resource: underground water. Following this, the society moved towards the full utilization of this resource. For instance, Chingleput had only 1,835 wells in around 2,300 hamlets at the beginning of the nineteenth century. Wells in those days were intended solely for drinking purposes. Well irrigation was definitely not widespread in South India at the start of the colonial period. Since then, the number of wells has increased steadily. As presented in Figure 2.3, the acreage irrigated by wells increased greatly and came to nearly half that of tanks and reservoirs by the early 1920s. Although temporary stagnation of its development occurred after World War I and after the Great Depression, well irrigation was already emerging as the most promising resource in the late 


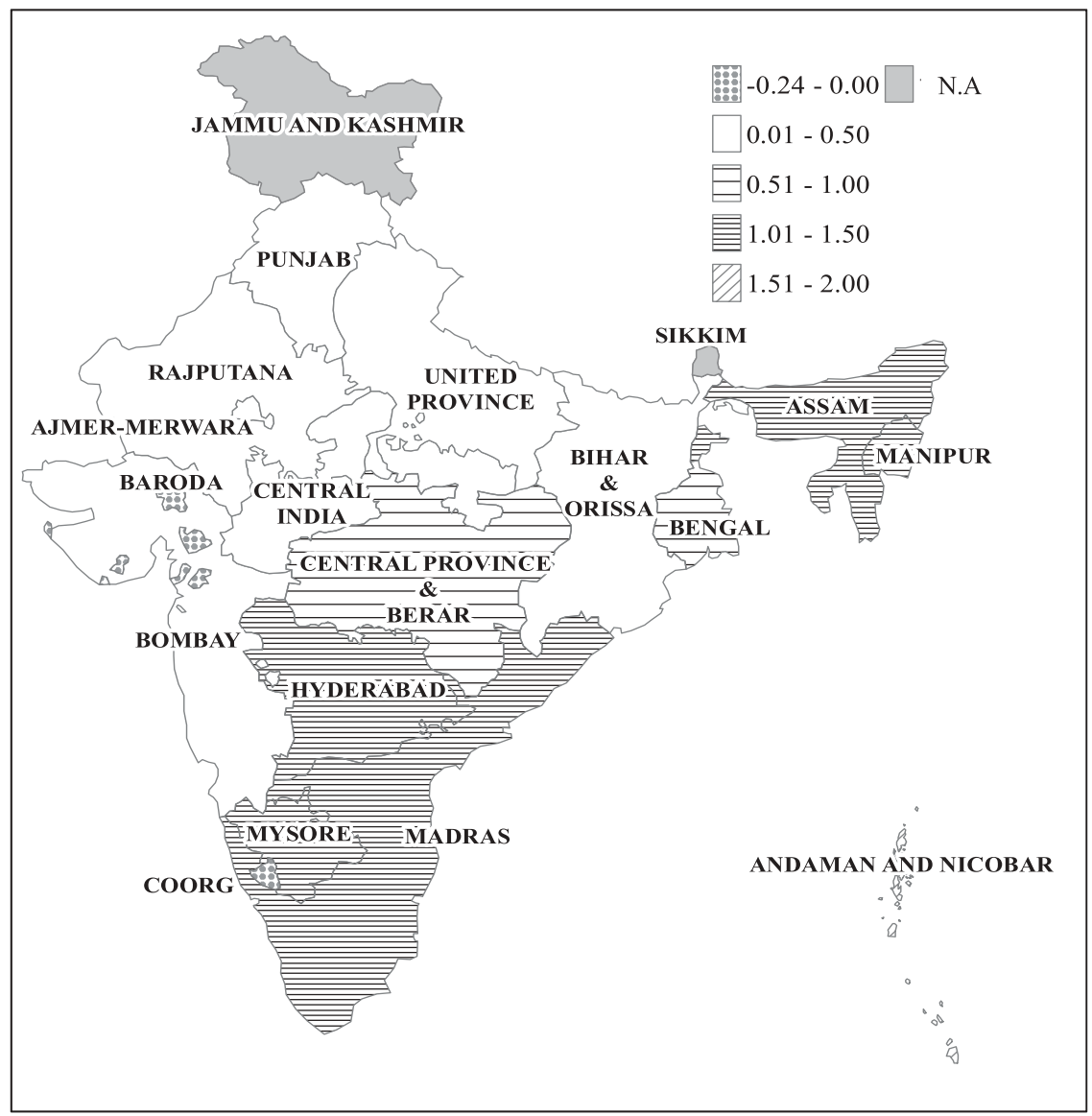

Map 2.6 Population Increase by Region, 1881-1911

Source: Variation in Population since 1872, Census of India, 1911, Volume I, Part II. Tables, Table II: pp. 5-10.

colonial period. It goes without saying that well irrigation has been the most important engine of agricultural expansion since the Green Revolution in the post-independence period.

The societal reason underlying the development and use of well irrigation must be explained because it has become the most important wellspring for agricultural development in South India. Unlike tanks, the maintenance of which necessitates people's unity and collaboration on a grand scale, well irrigation enables individual usage of water. Reservoirs used to be maintained in the mirasi system in the pre-colonial period; the communal practice of their maintenance remained for some time as kudimarammat in the colonial period. 


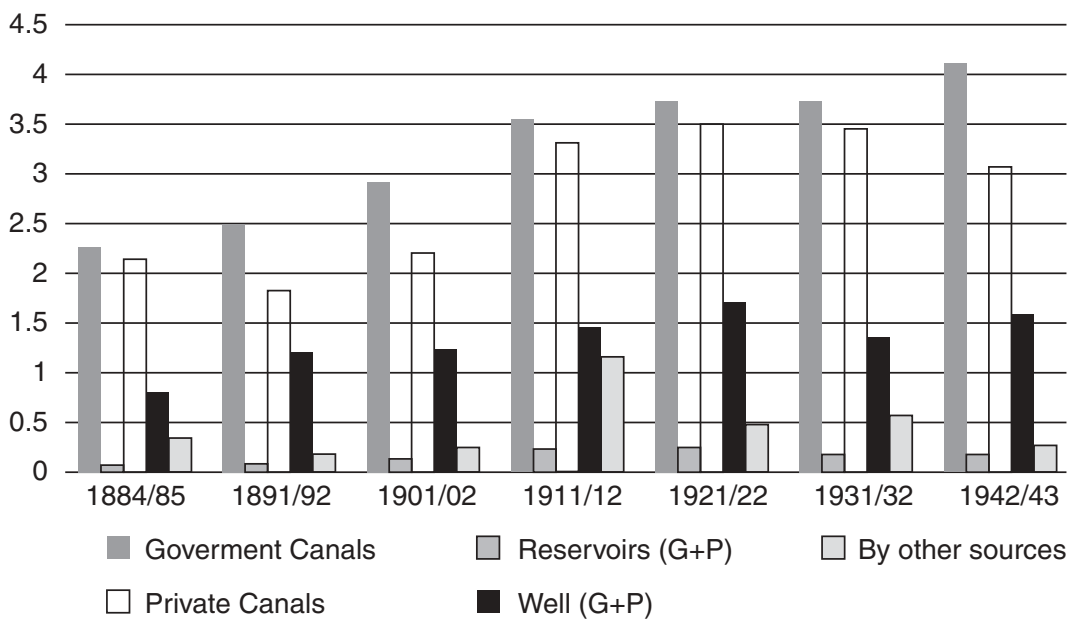

Figure 2.3 Development of Well Irrigation in the Madras Presidency during the Late Colonial Period

Source: prepared from The Agricultural Statistics of British India, 1884/85, 1891/92, 1901/02, 1911/12, 1921/22, 1931/32, 1942/43.

However, with the decline of unity among the villagers, the tanks played ever less important roles. We know that many tanks have been abandoned already.

After sustaining numerous deaths and debilitating illness from influenza in 1918-19, South India has maintained a high population growth rate until recently. The stability of agriculture maintained through groundwater resources has contributed greatly to growth from the 1920s onwards. Agricultural development, especially after the Green Revolution, has supported a huge population in India. Actually, India has emerged as an important grain exporting country during the past few decades. Under such circumstances, both agriculture and population seem to have entered a new stage with a low total fertility rate (TFR) and abandonment of agriculture on a large scale. These issues will be addressed in other chapters of this book.

\section{Notes}

* The original version of this chapter was read at the workshop held on 16 December, 2016.

1 Some village records have been torn. For that reason, accurate total numbers of hamlets are not available. Most probably, the Jagir had around 2,300 villages in the late eighteenth century.

2 For the historical demography in the pre-colonial and colonial periods, see Visaria and Visaria, 1982; Habib, 1982; Moosvi, 1973 and 1987; Desai, 1972; Davis, 1951. As to the demographic change from the late nineteenth to the late twentieth century in South India, see Gopinath, 2010. 


\section{Tsukasa Mizushima}

3 Zamindari Statement, Statement relating to Permanent Settlement of Jagir forwarded as Enclosures to Mr. Greenway's Letter, 29 March, 1801 (Permanent Settlement Records, Vols. 20-22).

4 The exceptions were merchants and weavers who were deeply involved in the emerging market economy of the period.

5 Although the so-called caste system is usually understood without any reference to the mirasi system, the caste system was indeed another expression of the mirasi system. Studies of the caste system in the modern period should be linked to the operation of the caste system with the pre-colonial production system in the localities.

6 Definitions of land ownership and landholding must be clarified here. The basic principle of the raiyatwari system was the raiyats' landholding under the state ownership. As discussed later in this chapter, severe resistance arose from the mirasidars, who claimed territorial ownership as landlords. When colonial power was not sufficiently strong to subdue the mirasidar claims, there existed a sort of double land ownership by the state and by the mirasidars. See the discussion presented below.

7 Regarding change of colonial land policies in Chingleput during the nineteenth century described below, see Mizushima (2002) and Crole (1879) for more details.

8 Public purposes here included railway construction.

9 A calculation from the 1877 Settlement Registers of Ponneri villages, covering 52 villages having 696 mirasidars in all, indicates that the average landlord rent (swatantram) received by a mirasidar was as little as Rs.7.

10 For details of population change in the early colonial rule, see Mizushima, 2014a.

\section{Primary Sources}

Agricultural Statistics of British India, 1884/85, 1891/92, 1901/02, 1911/12, 1921/22, 1931/32, 1942/43.

Barnard Records: Jaghire - Barnard's Survey Accounts (1770s).

Census of India and Census of the Madras Presidency, 1871, 1911.

Field study by the author, 1979-81, 2007-08.

Settlement Registers, Ponneri Taluk (1877) and Lalgudi Taluk (1864, 1894, 1924).

Zamindari Statement, Statement relating to Permanent Settlement of Jagir forwarded as Enclosures to Mr. Greenway's Letter, 29 March, 1801 (Permanent Settlement Records, vols. 20-22).

\section{References}

Crole, C. S. (1879). The Chingleput, Late Madras District, A Manual Compiled under the Orders of the Madras Government, Madras: Lawrence Asylum Press.

Davis, K. (1951). The Population of India and Pakistan, Princeton NJ: Princeton University Press, pp. 24-27.

Desai, A. V. (1972). "Population and Standards of Living in Akbar's Time," The Indian Economic and Social History Review, vol. IX (1), pp. 43-62.

Gopinath, R. (2010). Historical Demography and Agrarian Regimes: Understanding Southern Indian Fertility, 1881-1981, Hyderabad: Orient Black Swan.

Guha, S. (2001). Health and Population in South Asia: From Earliest Times to the Present, London: Hurst \& Company.

Habib, I. (1982). "Population," in Kumar, D. and Raychaudhuri, T. eds., The Cambridge Economic History of India, volume I: c.1200-c.1750, Cambridge: Cambridge University Press, pp. 163-71. 
Kotani, H., T. Mizushima and M. Mita. (2008). "Indian History from Medieval to Modern Periods: An Alternative to the Land-System-Centred Perspective," International Journal of South Asian Studies, vol. 1, pp. 31-49.

Kumar, D. (1965). Land and Caste in South India: Agricultural Labour in the Madras Presidency during the Nineteenth Century, Cambridge: Cambridge University Press.

Maddison, A. (2009). Historical Statistics of the World Economy: 1-2008 AD (downloaded on 17 July, 2017, www.ggdc.net/maddison/oriindex.htm)

Mizushima, T. (2002). "From Mirasidar to Pattadar: South India in the Late Nineteenth Century, Land, Politics and Trade in South Asia, 18th-20th Centuries," Essays in Memory of Dharma Kumar, Indian Economic and Social History Review, vol. 39 (2\&3), pp. 259-84.

Mizushima, T. (2006). "The Mirasi System as Social Grammar: State, Local Society, and Raiyat in Eighteenth-Nineteenth Century South India," in Kimura, M. and A. Tanabe eds., The State in India: Past and Present, London: Oxford University Press, pp. 140-201.

Mizushima, T. (2014a). "Did India Experience Rapid Population Growth in the PreCensus Period?: A Village-Level Study from South India," International Journal of South Asian Studies, vol. 6, pp. 13-43.

Mizushima, T. (2014b) "Mirasidars and Colonial Land Systems," in Karashima, K. ed., A Concise History of South India: Issues and Interpretations, Delhi: Oxford University Press, pp. 266-73.

Moosvi, S. (1973). "Production, Consumption and Population in Akbar's Time," The Indian Economic and Social History Review, vol. X (2), pp. 181-95.

Moosvi, S. (1987). The Economy of the Mughal Empire C. 1595: A Statistical Study, Delhi: Oxford University Press, Chapter 17.

Saito, O. (2002). "Kikin to Shibou to Jinkou Hendou [in Japanese: Famine, Mortality, and Population Movement]," in Yanagisawa, H. ed., Gendai Minami Ajia 4: Kaihatsu to Kankyo [Modern South Asia 4: Development and Environment], Tokyo: Tokyo Daigaku Syuppankai [The University of Tokyo Press], pp. 165-86.

Visaria, L. and P. Visaria. (1982). "Population (1757-1947)," in Kumar, D. (ed), The Cambridge Economic History of India, Vol. II, c. 1757-1970, Cambridge: Cambridge University Press, pp. 465-66. 


\title{
3 From sharing risks to taking risks The system of entitlements and its fragmentation in eighteenth and nineteenth century Orissa
}

\author{
Akio Tanabe \\ PROFESSOR AT GRADUATE SCHOOL OF ARTS AND SCIENCES, \\ THE UNIVERSITY OF TOKYO
}

\section{Introduction}

This chapter presents the manner in which what I call 'the system of entitlements', actually the system of resource sharing based on entitlements and duties in a local society, functioned as a mechanism to share agricultural risks mainly caused by erratic rainfall in eighteenth century Khurda, Orissa, and how this system of risk management fragmented in the early nineteenth century, resulting in the loss of sustainability. ${ }^{1}$ Particularly examined is a case study of a local community: Garh Manitri. There, one of the main seventy-two forts was situated in the Khurda Kingdom (circa 1570-1804). Garh actually means 'fort'. Because virtually no irrigation was used except for village ponds in pre-colonial times of the early modern Khurda, risk management was extremely important for the area's sustainable livelihood. That management was practiced through the social system: the mechanism of 'sociological adaptation'. This chapter presents an attempt to understand the socio-ecological logic of the so-called 'caste system' in early modern Orissa in its own light, with examination of how the introduction, under colonial rule, of private proprietary rights and the liberal economic principles that encouraged 'taking risks' accompanied the creation of the 'unitary caste hierarchy' in the early nineteenth century.

The premise of 'the system of entitlements' is that there existed diversity in the kinds of work in which people were engaged. One must remember that there were 'many and diverse paths along which the peoples of the eighteenth century had earned their livings' in India (Washbrook, 1988: 80). This point is often missed because administrators and scholars since the colonial period have specifically devoted their attention to paddy fields as a means of revenue collection. Furthermore, Gadgil and Guha explain 'diversification of the use of biological resources by endogamous groups' (Gadgil and Guha, 1992: 207), and how this enabled more coordination than competition in terms of resource use. However, it is noteworthy that criticisms have been leveled 
against the 'neo-traditionalist' tendency to romanticize the pre-colonial past (Sinha et al., 1997; Grove et al., 1998; Guha, 1999a, 1999b). We must be cognizant of both elements of coordination and cooperation as well as hierarchy and domination between endogamous groups ('castes') in pre-colonial Indian society. There was certainly an aspect of the social gradient and inequality as one part of sociological adaptation.

Aside from diversity in the forms of living, agricultural production and food were also diverse. Moreover, seasonal diversity prevailed, with various social groups engaging themselves in non-agricultural duties such as military, artisanal, and service activities during the off-season, but working in agriculture during the on-season. With such diversity in the kinds of work, agricultural production and seasonal activities functioned as mechanisms for reducing risk and using human resources in more effective ways. Based on these shifting diversities in production activities, the system of entitlements functioned to support the sharing of both the fruits of various activities and the agricultural risks in the local community.

The colonial government of the East India Company, however, introduced the ryotwari system into the Khurda region without understanding the mechanism of the system of entitlements that had been embedded in the socioecological conditions. Consequently, the system of entitlements was fragmented. Moreover, reduction of diversity in crops and occupation (peasantization) occurred concomitantly with the commercialization of agriculture. No more sharing of risk took place in the local community as individual households began to take risks and prioritize profit over the security of livelihood. The logic of the market economy reshaped the agrarian society in significant ways, thereby reducing the security of livelihood in the region, and tightening the socioeconomic structure of hierarchy and dominance.

\section{Socio-ecological diversity in pre-colonial agrarian society in Khurda}

In the dry hilly tracts of Khurda, ample evidence suggests greater diversity in the modes of living in pre-colonial times. In 1830, just a quarter of a century after colonization, 68.51 percent of Khurda and 88.86 percent of Garh Manitri were occupied by forests, hills, and fields (Tables 3.1 and 3.2). Vast tracts of forest and pastoral land played important parts in the lives of the people. The tribal Saoras and Khondhas and low caste Bāuri engaged in hunting wild animals (rabbits, lizards, birds) and gathering forest products (wild vegetables such as kānkaṇa, berries, nuts, honey, firewood). Additionally, it was common practice among the villagers to clear areas of the forest and to engage in slash-and-burn agriculture or shifting cultivation. Villagers would produce millets, usually finger millet (Oriya: māndiā, Eleusine corocana), in the first year and then cotton in the second year. In the third year they moved on to another patch while allowing the used land to regain fertility. Such places are called toilā (cotton field) even today, although the practice of cotton cultivation has stopped. It must be pointed 
Table 3.1 Types of Land in Khurda Region, 1836 (acres)

\begin{tabular}{llllll}
\hline Total & $\begin{array}{l}\text { Area outside } \\
\text { jurisdiction }\end{array}$ & $\begin{array}{l}\text { Total area } \\
\text { under } \\
\text { jurisdiction }\end{array}$ & $\begin{array}{l}\text { Cultivated } \\
\text { land }\end{array}$ & $\begin{array}{l}\text { Land cultivable } \\
\text { not cultivated }\end{array}$ & $\begin{array}{l}\text { Forest, } \\
\text { hills and } \\
\text { fields }\end{array}$ \\
\hline 631283.5825306 .92 & $\begin{array}{l}605976.66 \\
(100 \%)\end{array}$ & $\begin{array}{l}161906.36 \\
(26.72 \%)\end{array}$ & $\begin{array}{l}28941.44 \\
(4.78 \%)\end{array}$ & $\begin{array}{l}415128.87 \\
(68.51 \%)\end{array}$ \\
\hline
\end{tabular}

Sources: Hota Report, p. iv; Mishra Report, p. 4; W. Wilkinson to the Commissioner for the 19th division, Balasore, no. 277, 24 October 1836, in Selections I. p. 134. Figures converted to acres by Tanabe.

Table 3.2 Types of Land in Garh Manitri, 1828-1830 (acres)

\begin{tabular}{llllllll}
\hline $\begin{array}{l}\text { Total } \\
\text { area }\end{array}$ & $\begin{array}{l}\text { Forest } \\
\text { and fields }\end{array}$ & $\begin{array}{l}\text { Cultivated } \\
\text { or } \\
\text { inhabited }\end{array}$ & $\begin{array}{l}\text { House } \\
\text { and back } \\
\text { yard }\end{array}$ & Rice & $\begin{array}{l}\text { Millet } \\
\text { (Forest } \\
\text { horti } \\
\text { culture) }\end{array}$ & $\begin{array}{l}\text { Cotton } \\
\text { (Forest } \\
\text { horti } \\
\text { culture) }\end{array}$ & Vegetable \\
\hline $\begin{array}{l}5796.890^{*} \\
(100 \%)\end{array}$ & $\begin{array}{l}5150.98 \\
(88.86 \%)\end{array}$ & $\begin{array}{l}645.91 \\
(11.14 \%)\end{array}$ & $\begin{array}{l}13.3 \\
(0.23 \%)\end{array}$ & $\begin{array}{l}502.43 \\
(8.67 \%)\end{array}$ & $\begin{array}{l}64.89 \\
(1.12 \%)\end{array}$ & $\begin{array}{l}63.94 \\
(1.10 \%)\end{array}$ & $\begin{array}{l}1.35 \\
(0.02 \%)\end{array}$ \\
\hline
\end{tabular}

Source: Palm leaf scripts collected by Tanabe at Garh Manitri. Figures converted to acres by Tanabe.

* Data of the total area are from the Census of Orissa. Because land records are available only for 75.93 percent of the villagers and 52.02 percent of outsiders owning land in Garh Manitri, other figures in this table have been estimated by increasing figures in the land records proportionately.

out that, in the case of the system of entitlements dealt with here, the resources distributed for the local community included slash-and-burn fields as well as pastoral and forest products in addition to wet-rice cultivation.

The production of resources in villages and its allotment to entitlement holders are also related to the demographic structure of the fort area. The 'fort area' here refers to the fort and the surrounding villages, which together formed a basic unit for socioeconomic reproduction through the system of entitlements. The numerous and diverse forms of living supported the necessity not only of peasants but also of soldiers, priests, merchants, and artisans, as well as pastoralists and forest-dwellers (Washbrook, 1988: 67). Table 3.3 presents the number of households in the Manitri fort area (circa 1800 AD) by village and caste.

The total number of households per village shows that out of 291 households in the total fort area, well over half (169; 58.08 percent) lived in the central fort-village (including Chhiam village). However, in the remainder of the surrounding villages there were only 6-32 households, or 15.25 households 


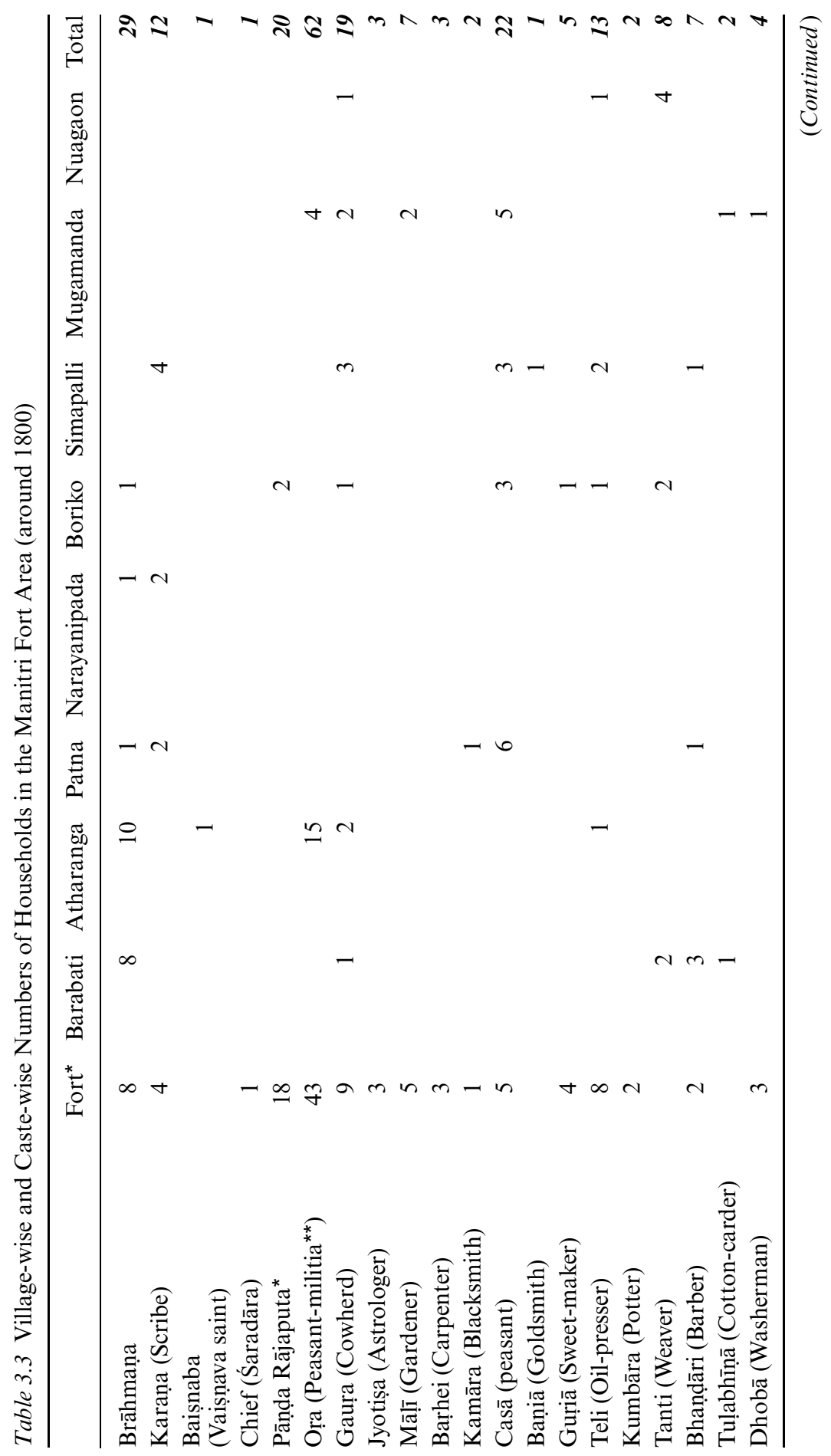




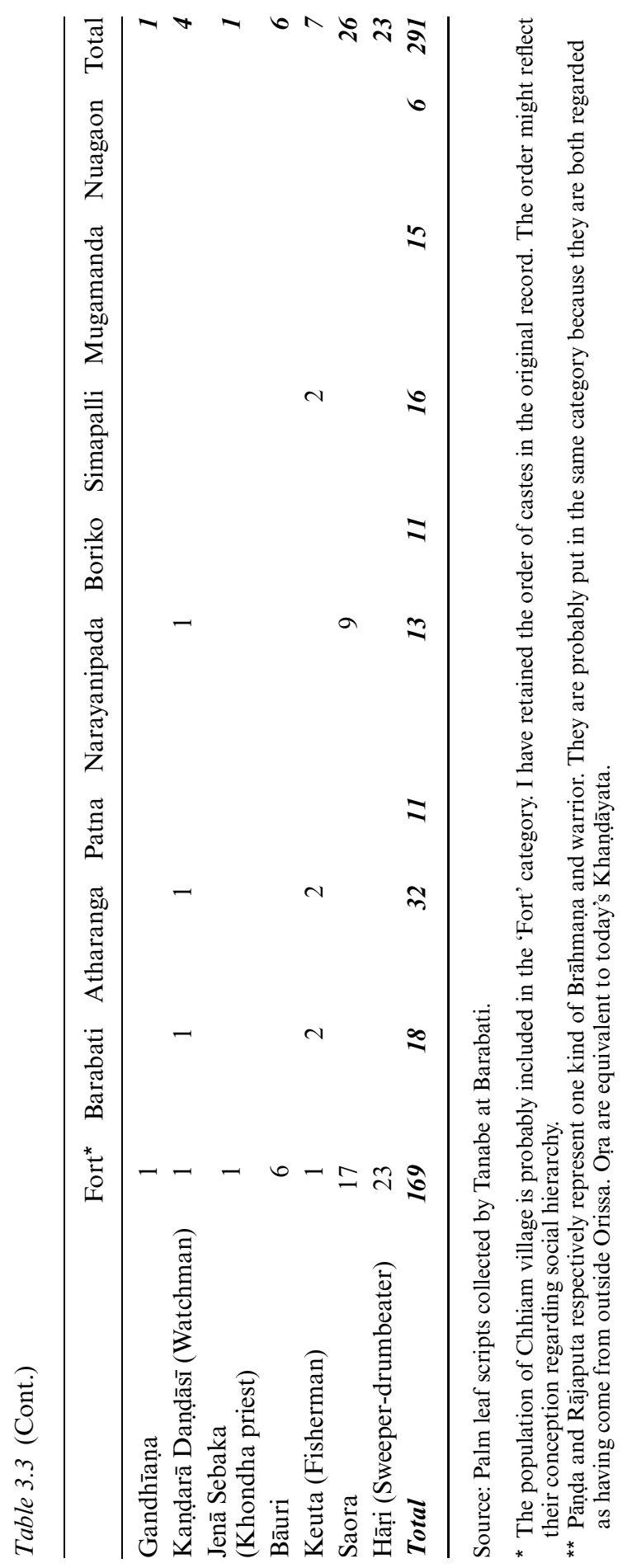


(5.24 percent) on average. Regarding the numbers by caste reveals that the 43 Ora or Khaṇdāyata (Peasant-militia) caste households engaged in military and administrative service are concentrated in the fort-village. The Chief lineage also belonged to this caste. Almost all other castes were represented there. In the surrounding villages, the presence of primary producers such as peasants is notable: Cowherds, Weavers, Oil-pressers and Fishermen. Most of the Brāhmaṇas living in the surrounding villages were probably Aṭhagaria Brāhmaṇas who did not perform any religious tasks such as those of priests. They engaged in agriculture. ${ }^{2}$ None of the surrounding villages had a sufficient variety of castes to enable one village to be autonomous. Apparently, they relied on the fort-village or other surrounding villages for supplies of services provided by various caste people. Roughly speaking, then, military, religious, and administrative specialists, such as Khaṇḍayatas, Scribes and Brāhmaṇas, together with other artisan and service castes necessary to constitute a local community were found in the central fort-village, whereas agricultural, pastoral and manufacturer castes who were involved in the production of economic resources lived in the surrounding villages. Resources from the surrounding villages together with those of the central fort-village were relied upon to provide for the needs of the fort area as the primary unit of socioeconomic reproduction. The surrounding villages depended politically and socially on the fort-village. They can be characterized as the providers of resources at the fort area level.

\section{System of entitlements and sustainability}

\subsection{Details of the system of entitlements in Garh Manitri, Khurda}

Next we examine some details of the system of entitlements in Garh Manitri. The author obtained data from palm-leaf scripts (Figures 3.1, 3.2) of the late eighteenth century, which give details of how much of each resource was available from each village, how they were allotted among various entitlement holders, and how much tax was levied on each.

In the system of entitlements in Khurda, a person was assigned a particular role or office in the community to perform duties accorded to that role. That person received a fixed amount of shares in the form of land, goods, services, and cash. Entitlement holders were recognized as members of the community. In addition to receiving tax-free residential land (mināha, minyā), they were given roles in community rituals, various privileges, and titles according to their office. In contrast, those who resided in the village but who held no entitlement were called 'outsiders' (cāndanā). They paid high rents to the community for their residential and agricultural land. ${ }^{3}$ Aside from those who received shares from the community as entitlement holders, administrative officers also obtained a salary from the state (Khurda kingdom), often along with shares from the community. These positions illustrate the marked penetration of state governance into the locality. 


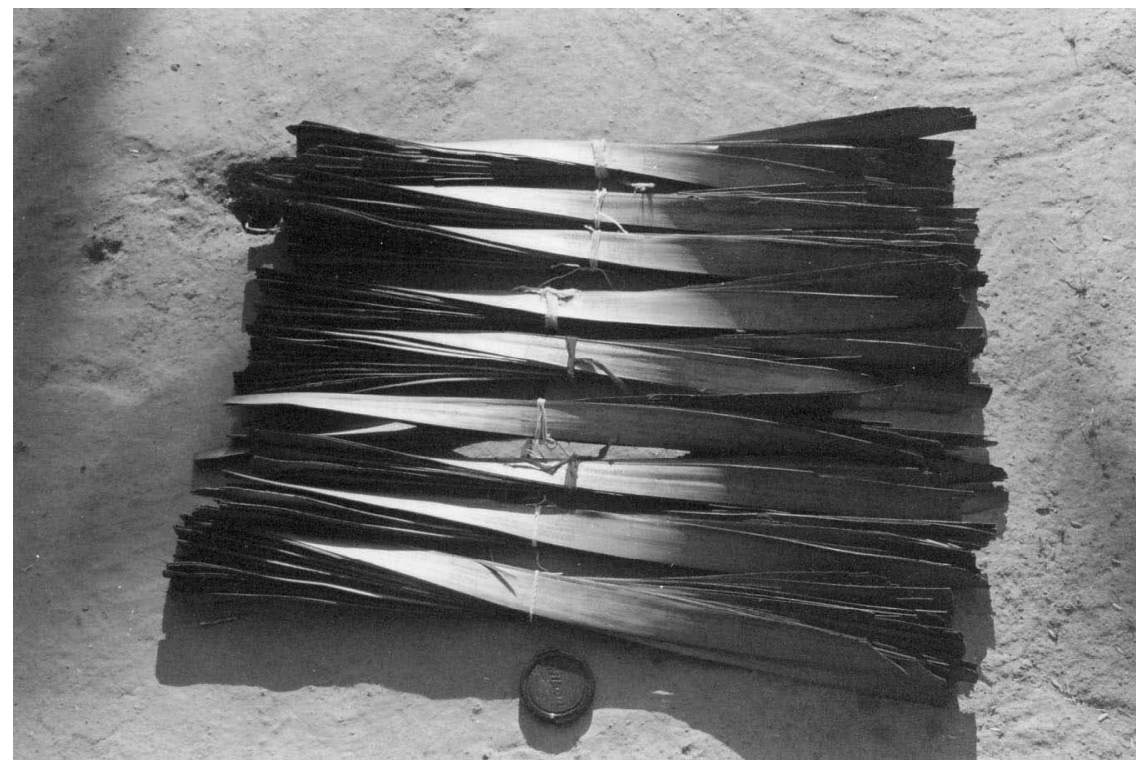

Figure 3.1 Bundles of Palm Leaf Scripts

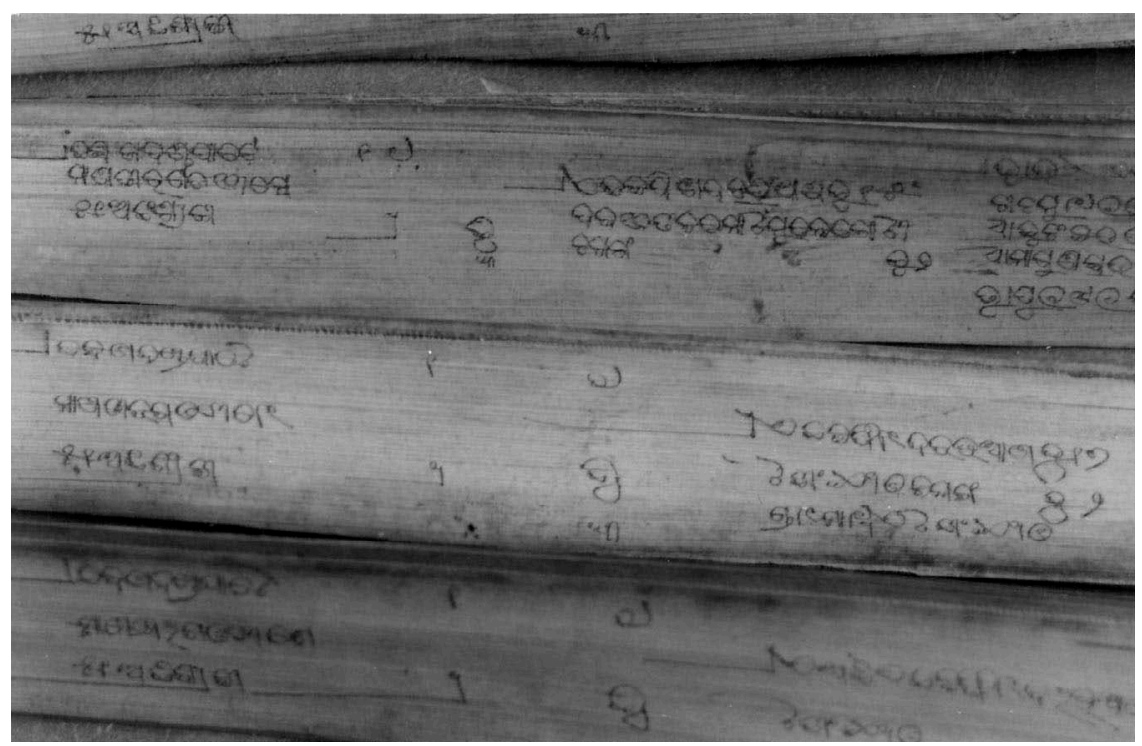

Figure 3.2 Examples of Administrative Records (bhiāna: 1776-1777 A.D.) on Palm Leaves 
The resources for redistribution in the fort area were divided into a 'land part' (bhumi bhāga, 86.47 percent), given in the form of land, and a 'cowry part' (kauri bhāga). The cowry part was further divided into a 'cash part' (nagada kauri, 1.35 percent) and 'khañjā supplies' (khañjā dara, 12.17 percent $).{ }^{4}$ The sum total of resources provided by the thirteen villages constituting the Manitri fort area was 13,115 kāhāna 8 paṇa 10 gandă ${ }^{5}$ The resources of the fort area are redistributed to entitlement holders in exchange for services they provide. Table 3.4 presents details related to the shares and taxes of entitlement holders. ${ }^{6}$

\subsection{Diversity as risk management: participation and sharing}

How can one understand the system of entitlements in terms of sustainability? One suggestion is that the system of entitlements incorporated a sociological mechanism to adapt to unpredictable rainfall in the area.

In the rural villages of pre-colonial Khurda, which was without irrigation except for village ponds and which had only around $1400 \mathrm{~mm}$ annual rainfall, agriculture was possible only when and if rainfall occurred. Villagers had to be prepared to complete tilling and sowing operations immediately after the rains started. During the subsequent busy farming season, which lasted until the harvesting season, villagers were required to work intensively at several stages. It was not simply that villagers could not predict when and how much it would rain. When it did rain, villagers were required to be able to put in a substantial amount of labor in a short time to be able to complete the necessary operations intensively and properly. Villagers could not complete these operations simply by mobilizing the labor power available within their households. However, they could not afford to employ numerous agricultural laborers on a fulltime basis because, in areas that experienced a monsoon climate, the vast majority of rainfall occurred during the rainy season, meaning that extra farm labor was not necessary during the remainder of the year. Furthermore, in situations where a consistent amount of precipitation could not be expected from one year to the next, it did not make sense to engage in intensive farming operations that required large inputs of labor power and capital. In fact, to do so would have often jeopardized the villagers' investments (Wakimura, 2009).

What, then, did villagers do to cope with these circumstances? As we saw in the case of the system of entitlements in Garh Manitri, the local community held various members from various service castes (e.g., Barbers, Sweepers, Laborers) and artisan castes (e.g., Carpenters, Potters, and Blacksmiths): They served as redundant agricultural laborers. The Foot Soldiers or the Peasant-militias (Khaṇdāyatas), who were the most numerous and powerful population group in the area, also engaged in both military service and agriculture. Although villagers engaged in their respective specialized occupations during the farming off-season, most of them, except for a few high office holders and Vedic (bhaidika) Brāhmaṇas, engaged themselves as 


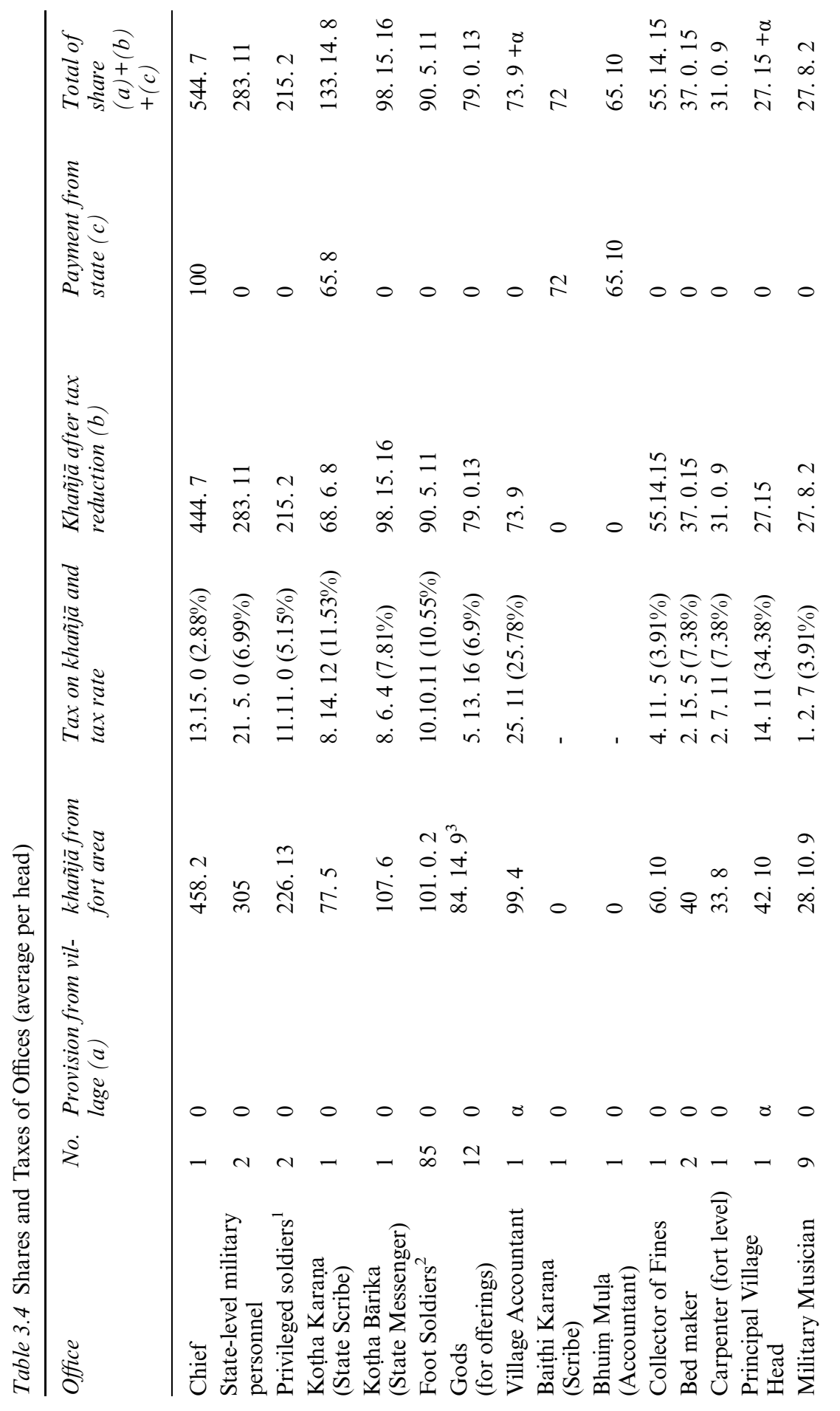




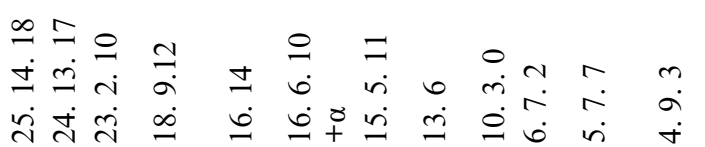

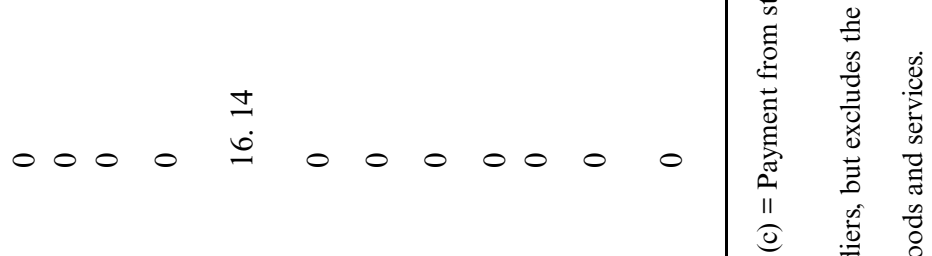

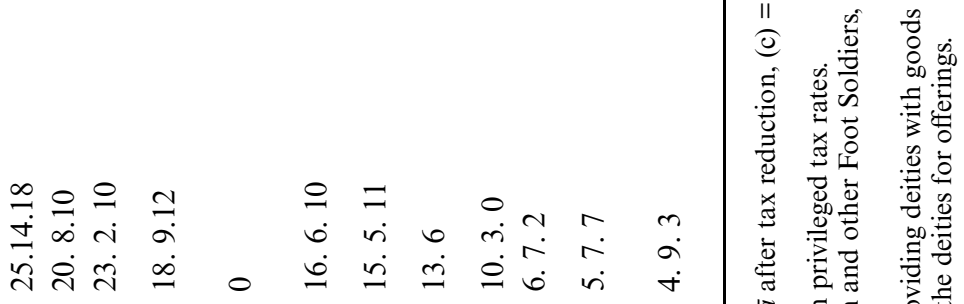

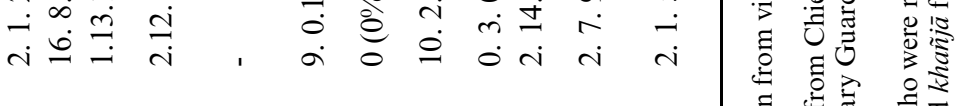

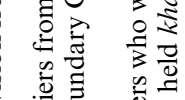

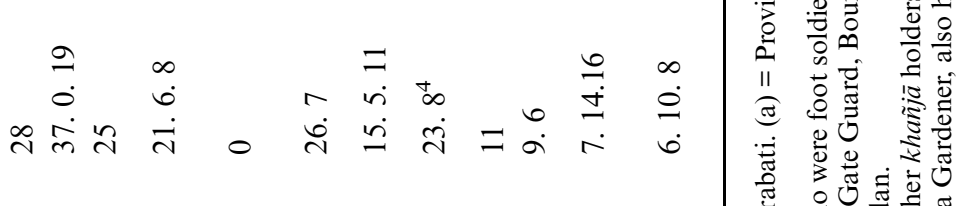

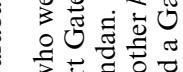

$$
\begin{aligned}
& \text { 3. 흠효 }
\end{aligned}
$$

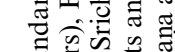

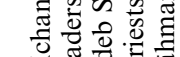

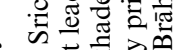

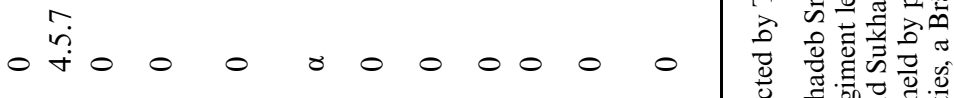

$$
\begin{aligned}
& -\infty-n--\vec{\lambda} \alpha-\alpha \Lambda-\overline{0}
\end{aligned}
$$

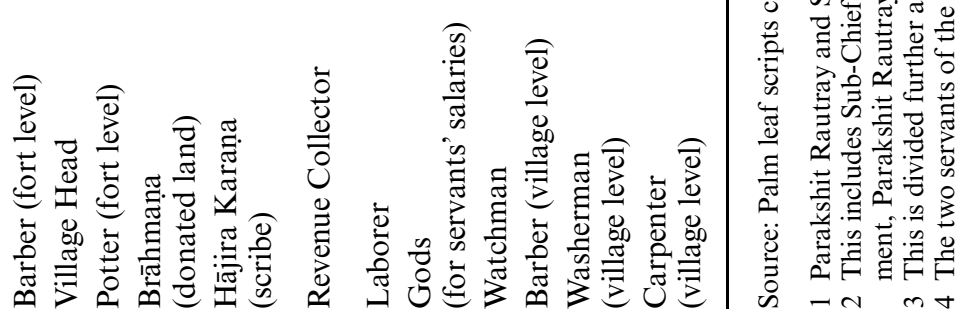


agriculturalists once farming operations began to pick up. To address fluctuations in rainfall, the society collectively developed a mechanism that could use each social group's specialized skills during the non-agricultural season and also use them as an agricultural force when necessary. The society maintained high labor efficiency by adopting seasonal shifts of labor between agricultural and non-agricultural work.

One might also note the diversity of occupations as well as dietary habits of various social groups in eighteenth-century Khurda. People made their living by engaging in a far greater variety of occupations than their presentday counterparts (Washbrook, 1988: 80). In addition to wet-rice cultivation in paddy fields, grazing domesticated animals such as cows, buffaloes, sheep, and goats in dry fields, slash-and-burn agriculture for producing cotton and millet, hunting of small game and gathering products in forest areas constituted important economic activities. Furthermore, the same social groups engaged in various services as well as craftwork, commerce, military, religious, and other activities.

These examples indicate that diverse social groups were able to use various natural resources existing in the area in various ways, and that society was collectively able to benefit from those resources through distribution and exchange. Consequently, the multilayered safety nets that existed could be relied upon to function in response to fluctuations in nature. It was, in fact, the close interconnection among diverse ecological environments, diverse livelihoods, and diverse social groups that afforded sustainability of livelihood in eighteenth-century Khurda.

\subsection{System of entitlements as a mode of 'sociological adaptation'}

The function of 'the system of entitlements' was not merely to accumulate surplus in the form of goods or money. It not only secured human livelihood; it also functioned to accumulate wealth in the form of diverse knowledge and skills in the social groups. This local system for the division of labor and resource distribution enabled various endogamous groups (castes) to engage in the acquisition and distribution of their respective knowledge and expertise while receiving the support of the local community for livelihood and survival. Through such arrangements, the society as a whole retained diverse expertise knowledge and skills and thereby enjoyed prosperity in terms of various goods and services maintained by such diversity. Consequently, this particular path of development functioned to maintain and increase social and cultural diversity in society. Distinct from both 'agronomic adaptation' with emphasis on manipulation of the biosphere (e.g. selective breeding or the use of floating rice in a flood prone area) and 'technological adaptation' to the environment with emphasis on manipulation of the geosphere (e.g. irrigation) reported by Ishii (1978), this approach might be designated as 'sociological adaptation' with emphasis on the manipulation of human society. 
The terms of 'agronomic adaptation' and 'technological adaptation' to nature were suggested by Ishii to explain the relation between state formation and rice culture development in continental Southeast Asia. He stated the following:

In some regions, people need only select rice varieties which are adapted to the given natural water conditions. The flood plain is one such region where people have mastered the rising floodwaters by selecting fast-growing varieties, for example, floating rice. In these regions, the knowledge required by the peasants is in a sense that of the agronomist: the knowledge to select appropriate varieties. This might be called 'agronomic adaptation' to nature. In contrast, in regions having no readily available water sources, the peasants must devote their energies to the use of rainwater or water from distant sources and to maintaining their supply. They must dig waterways, install water-lifting devices, build dikes, dam rivers, and construct reservoirs. This approach might be called a 'technological adaptation'.

(Ishii, 1978: 18)

The natural environment in India is more unpredictable than that in continental Southeast Asia, where Ishii developed his idea. The framework of 'agronomic adaptation' and 'technological adaptation' is based on the idea that society can make adaptations to nature by manipulating either the biosphere or geosphere. However, in the case of Khurda, and many parts of India, the characteristics of the environment are such that adaptation is not possible through either agronomic or technological manipulations. It was only possible to accept the natural conditions and adapt to the environment by adjusting human society itself. Instead of manipulating the biosphere as in 'agronomic adaptation' or transforming the geosphere as in 'technological adaptation', 'sociological adaptation' is managed by minutely defining the entitlement of each social group, thereby collectively sharing risks while enforcing a social gradient.

Whereas 'sociological adaptation' does not modify the biosphere or geosphere and because it is completely environment-adaptive, ${ }^{8}$ it should not be overlooked that the sociological adaptation imposes a heavy strain on human society. It requires high-level social sanctions among the community members over social order that involves socioeconomic inequality. A marked gap existed in the amount of shares each entitlement holder received (see Table 3.4). This difference is related to the socioeconomic hierarchy that was evident in eighteenth-century Indian society. What is worth noting, however, is that even members of lower castes were assured of survival because of their entitlement to a certain share of the local community's total output. Crop yields might vary from one year to the next depending on the level of precipitation and severity of damage because of natural disasters in any given year. Nevertheless, in contrast to a system that charges 
a fixed rent, such a system guaranteed each caste a certain share of the harvest, which enabled the local community as a whole to absorb the risks of fluctuating annual yields. Moreover, it can be pointed out that there was no scarcity of agricultural land in eighteenth-century India (Wakimura, 2009). Agricultural laborers were in demand when there was sufficient rainfall. The demand for labor increased still further because of an economic boom brought by thriving trade across the Indian Ocean (Washbrook, 1993). In the case of Khurda, cotton textiles were in high demand for exports. Various social groups including weavers, cotton-carders, various teasers and spinners, and peasants who cultivated cotton in the slash-and-burn fields, including not only Khaṇ̦āyatas (Peasant-militia) but also, more importantly, Bāuris ('untouchable' laborers) and Saoras (tribal), whose dependence on slash-and-burn fields was greater. The result was that members of lower castes were earning real wages that were considerably higher than those of their counterparts in the nineteenth century. In fact, Washbrook argues that members of the untouchable caste were better off economically in the eighteenth century than their counterparts in the subsequent century; the eighteenth century can be called the 'Golden Age of the Pariah' (Washbrook, 1993: 73; Wakimura, 2009). This does not of course mean that the members of the untouchable caste had a stable life. In case there was no sufficient rain or harvest, the untouchable caste members were expected to leave the community and emigrate elsewhere, where they would be able to find jobs and food. Consequently, the untouchable caste members were expected to act as a 'safety valve' for the community, which meant that they themselves had to move around to relieve pressure from rain-scarce or harvest-scarce areas and to provide labor where there was more demand depending on agricultural artisanal needs. This inequality in membership was a part of the sociological adaptation.

It is worth noting that in the eighteenth century, the system of entitlements based in the local community played a role that was complementary to the market economy which extended to trade across the Indian Ocean. India at the time was the world's largest exporter of cotton cloth, the country's primary export item. Large quantities of cotton cloth were transported from Bengal and Southern India to Europe. Women and members of lower castes performed the vast majority of the work of growing cotton, removing seeds from flowers, and spinning the cotton into thread. Consequently, in the wider context of trans-Indian Ocean trade of cotton cloth, women and members of lower castes in rural areas participated in various economic activities supporting the export of cotton cloth. For their efforts, they obtained some income earned from the cotton cloth trade. Cotton cloth weavers and merchants involved in the export of the cotton cloth paid enormous sums in taxes to local communities, even though they were without entitlement and were therefore 'outsiders' in these communities. Therefore, they were putting a part of their earnings from the trans-Indian Ocean trade back into the local 
communities. The system of entitlements in the local community and the trans-Indian Ocean trade in which artisans and merchants were engaged therefore functioned in a complementary manner.

In this way, the social system for division of labor and resource distribution based on the diversity of social groups, known as castes, was not merely a system of discrimination and exploitation: it was also a system in which various social groups were able to secure a place and opportunity for survival, although in an uneven manner. It was based on the logic of participation and sharing according to one's entitlement in a diverse and hierarchical society.

\section{Transformation of Orissan agrarian society under colonialism}

\subsection{Introduction of proprietary rights and the fragmentation of the system of entitlements}

After the defeat of 1804, the Khurda king was stripped of all his political rights. He lost his estates to the colonial government of the East Indian Company. The former territory of the Khurda kingdom became khas mahal, or a government estate, under the direct management of the colonial administration. Major Fletcher, who led the conquest of Khurda, was appointed to its administration in 1805 . When he came into office, he confiscated the land part of entitlement belonging to the chiefs (Dalabeherā), sub-chiefs (Dalai), foot soldiers (Pāika) and other office holders, which the British saw as given for 'political' office that had to be abolished in the new regime. Only those employed as Sarabarākāras, ${ }^{9}$ or tax-collecting officers under the colonial government, received new jagirs ${ }^{10}$ (land given in lieu of service) with quit-rent.

Land taxes were the major source of income for the British government (East India Co.) in the early nineteenth century. Fletcher attempted to maximize revenue from Khurda. As a result, the land tax revenues increased at fluctuating and arbitrary rates with successive temporary settlements from Rs.114,320 in gross in 1805-1806, to Rs.114,914 in 1813-1814, to Rs.122,306 in 1814-1815, and to Rs.141,845 in 1815-1816. ${ }^{11}$ The results of rising taxes were devastating for the peasants in Khurda. Many deserted their villages to escape the oppression. ${ }^{12}$

The condition of the Oriya cultivators was aggravated also with the depreciation of cowry (kauri), which had been used as the main currency at the local market as well as for payment of cash taxes to the king. ${ }^{13}$ The rate of exchange between cowries and silver was three to four kähānas per rupee under the Marathas (Sterling, 1904 (1846): 36). The exchange rate according to the circa 1800 records in Garh Manitri was four kähannas to a rupee. After colonization, however, because the tax was required to be paid in rupees in 1809 and because copper coins were introduced into 1811, the value of cowry depreciated to as low as 7 kăhạnas per rupee (De, 1961: XXVI). The local 


\section{2}

Akio Tanabe

residents suffered also from this depreciation of cowry, which they had long been using for local market exchange and tax payments.

The people most severely affected by the early British colonial policy were peasants, Peasant-militias (Pāika or Khaṇdāyata), and their superiors (Daḷabeherā, and Dalai). The dissatisfaction of Peasant-militias and their superiors was especially grave. They had enjoyed special privileges in the pre-colonial period, but they were to suffer much hardship because of the confiscation of their jagir estates ('land part' of entitlements) by the British and the rise in taxes, aside from the humiliation of being deprived of honorable positions as the king's local representatives and soldiers. Their dissatisfaction culminated in the Paika Rebellion of 1817 (Tanabe, 2020).

After the rebellion, the British were forced to reflect upon and reformulate their colonial policy in Khurda and coastal Orissa. As a consequence of the confusion and resistance, both passive and open, "parts of Khordah were almost entirely depopulated, large tracts of arable land thrown out of cultivation, and all revenue work came to a standstill'. ${ }^{14}$

After abandoning the collection of 1817-1818, the gross land tax was lowered to about Rs.50,000. ${ }^{15}$ Thereafter, no increase was made in the rate of land tax until minute measurements and settlements were made for different classes of land later in 1836.

From the 1820s, the British government began to conduct systematic administrative measures over land. This was expected because the tax levied on land was one of the main sources of revenue for the colonial government. The revenue administration of survey and settlement, however, showed an almost paranoiac effort at systematic categorization and enumeration (Cohn, 1987; Appadurai, 1993).

The colonial government ignored the fact that land use and resource distribution were intimately related to the relations of division of labor and cooperation in the local society. They deliberately disassociated land rights from socio-political relations in the local community, and instead classified land by the kind of tax and by quantity. Moreover, they determined the cultivator (or the de facto landowner), i.e. the taxpayer, for each piece of land. In 1820, the new Deputy Collector to Khurda, Mr. Wilkinson, for the first time in the region, issued the 'deed of right' (patāa) for their lands to ascertain the landowner. As a result, Sarabarākāras (Tax-Collectors) began to grant deeds of right to their landowners for the first time in the history of Khurda and thereby laid a foundation for cultivator-based (ryotwari) settlement.

In the settlement of 1836, uniform measurements were first introduced; settlements were made with the cultivators. The survey and settlement of 1836 brought about profound changes in the land system of the Khurda region. The British colonial government sorted out the rights that had existed in multilayered ways on a certain piece of land, allocated a deed of right to one person, and thereby granted exclusive proprietary rights in addition to allocating the responsibility of paying taxes. 
In this way, land was alienated, so to speak, from the socio-political relations it had formerly represented and supported. It became the property of individuals. Consequently, the system of entitlements that had supported the collective sustainability of the local community was broken. The land, instead of being a medium for organizing local community, became the object of individual ownership through which society came to be stratified. The introduction of ownership of land was legitimized by the British government in the 'liberalist' discourse to bring about private proprietorship free from the oppressive structure of hierarchical society (Mehta, 1999). However, what the British policy brought about, in fact, was a reification of socioeconomic hierarchy based on landholdings.

First, the settlement of 1836 had the effect of consolidating the position of the local elites, using them as Sarabarākāras (Tax-Collectors) in the colonial government. The old privileged classes of Daḷabeherās, Daḷis, Koṭha Karaṇas, Baiṭhi Karaṇas, Bhuim Muḷas, Pradhānas, etc. - that is, ex-office holders in the military, administrative and revenue posts at local levels - were chosen for the posts. They agreed to collect and pay the government cultivators' rent, and were allowed to take jagir lands and money: about 20 percent of the collection. ${ }^{16}$ The colonial government, by granting them the post of TaxCollector, preserved their politico-economic privilege and as a consequence gave official support to their 'traditional' position as local elites.

Secondly, the lands used for 'religious' purposes were, with the colonial 'liberal' policy of non-interference into 'native' religious affairs, allowed to be retained in the hands of the previous occupants either rent-free (lakhirajdar) or with light rent (tankidar). These privileged landholdings included debattār that had been donated to the gods and goddesses, and brāhmattār that had been donated to the Brāhmaṇas. The class of people who benefited most from this colonial policy was definitely the Brāhmaṇas. Many Brāhmaṇas were given de facto exclusive land ownership and tax reduction privileges on the donated lands by the colonial government and came to form a part of the large landlord class by the latter half of the nineteenth century.

In Garh Manitri, the amount of land held by the Brāhmanas increased dramatically from 9.110 acres $(2.64$ percent of the total cultivated land in the village) in 1829-1830 to 124.048 acres (17.26 percent) in 1911 (Table 3.5). The colonial government's policy of non-interference in religious affairs had in effect led to the preferential protection of religious specialists, especially the Brāhmaṇas, who maintained and extended their position as a privileged class.

The Pāikas or Peasant-militias who had received a share of entitlements as foot soldiers of the fort were reduced to mere cultivators under the 1836 settlement. Their landholdings were to be assessed at an ordinary tax rate. The settlement, simultaneously, however, confirmed the position of Paiikas who were mostly of Khanḍāyata caste as the largest caste-wise landholders (Table 3.5). Consequently, the Khaṇ̣āyatas were transformed in the early colonial period from the 'king's soldiers' to the 'dominant caste', whose ownership of land became an important basis of social authority. The 
Table 3.5 Land Ownership by Caste in Garh Manitri, 1829-1830, 1911 (acres)

\begin{tabular}{|c|c|c|c|c|c|}
\hline \multirow[t]{2}{*}{$J a ̄ t i$} & \multicolumn{2}{|c|}{$1829-1830$} & \multicolumn{2}{|c|}{1911} & \multirow{2}{*}{$\begin{array}{l}\text { Rate of } \\
\text { increase from } \\
1829-1830 \text { to } \\
1911\end{array}$} \\
\hline & acre & percentage & acre & percentage & \\
\hline Brāhmaṇa & 9.110 & $(2.64 \%)$ & 124.048 & $(17.26 \%)$ & $1261.67 \%$ \\
\hline Teli (Oil-presser) & 4.240 & $(1.23 \%)$ & 41.434 & $(5.77 \%)$ & $877.22 \%$ \\
\hline Keuta (Fisherman) & 0.260 & $(0.08 \%)$ & 2.219 & $(0.09 \%)$ & $753.46 \%$ \\
\hline Kumbāra (Potter) & 3.400 & $(0.98 \%)$ & 15.571 & $(2.17 \%)$ & $357.97 \%$ \\
\hline Bāuri (Laborer) & 2.220 & $(0.6 \%)$ & 6.718 & $(0.94 \%)$ & $202.61 \%$ \\
\hline Guriā (Sweet-maker) & 12.160 & $(3.52 \%)$ & 34.574 & $(4.81 \%)$ & $184.33 \%$ \\
\hline Gaura (Cowherd) & 22.130 & $(6.4 \%)$ & 60.675 & $(8.44 \%)$ & $174.18 \%$ \\
\hline Bhaṇḍāri (Barber) & 6.450 & $(1.87 \%)$ & 9.997 & $(1.39 \%)$ & $54.99 \%$ \\
\hline $\begin{array}{l}\text { Khaṇḍāyata (Peas- } \\
\text { ant-militia) }\end{array}$ & 205.570 & $(59.49 \%)$ & 308.382 & $(42.92 \%)$ & $50.01 \%$ \\
\hline $\begin{array}{l}\text { Kamāra } \\
\text { (Blacksmith) }\end{array}$ & 12.970 & $(3.75 \%)$ & 11.043 & $(1.54 \%)$ & $-14.86 \%$ \\
\hline Khondha (Tribal) & 2.230 & $(0.65 \%)$ & 1.558 & $(0.22 \%)$ & $-30.13 \%$ \\
\hline Dhobā (Washerman) & 9.520 & $(2.75 \%)$ & 6.468 & $(0.9 \%)$ & $-32.06 \%$ \\
\hline Jyotișa (Astrologer) & 1.590 & $(0.46 \%)$ & 0.964 & $(0.13 \%)$ & $-39.37 \%$ \\
\hline Hāṛi (Sweeper) & 24.320 & $(7.04 \%)$ & 12.433 & $(1.73 \%)$ & $-48.88 \%$ \\
\hline $\begin{array}{l}\text { Saora (Tribal) } \\
\text { Brāhmana }\end{array}$ & 7.890 & $(2.28 \%)$ & 2.908 & $(0.4 \%)$ & $-63.14 \%$ \\
\hline Karạ̣a (Scribe) & 21.520 & $(6.23 \%)$ & 2.549 & $(0.35 \%)$ & $-88.16 \%$ \\
\hline Baṛhei (Carpenter) & Unknown & & 39.395 & $(5.48 \%)$ & unknown \\
\hline Māḹ (Gardener) & Unknown & & 8.449 & $(1.18 \%)$ & unknown \\
\hline Total & 345.580 & $(100 \%)$ & 718.495 & $(100 \%)$ & $107.91 \%$ \\
\hline
\end{tabular}

Source: Palm leaf scripts collected at Garh Manitri for 1829-1830 and land settlement records collected from Ekharajat Mahal office for 1911. Both collected by Tanabe. Note: Figures of average per household in 1829-1830 for Brāhmaṇa and Mālī underrepresent their economic status because they had the deities' lands in their possession, but these were not yet registered in their names at this stage. Landholdings of jagir or deity's land as trustees are included in figures for 1911.

'dominant caste' in the sense of a community of landholders was therefore a creation of the colonial administration. ${ }^{17}$

Regarding the entitlement lands of the community servants of carpenters, blacksmiths, and washermen, tax-free possession of them was permitted as long as they continued to serve the community. The custom of payment that the community servants gained from each household remained in form, but its meaning had changed dramatically in the colonial period. As the system of entitlements broke down, service castes performed services less and less for the community as a whole, but for individual households that 
gave them payment for services rendered. The exchange of service and grain came to be based on dyadic relations between the patron (jajmāna) household and the service caste households. Consequently, what is regarded as customary exchanges between patron and client households in the so-called 'jajmani system' is a product of colonial history where customs were reinvented after the system of entitlements broke down. Each household had to become the autonomous agent as the unit of exchange. In this way, a new kind of 'unitary caste hierarchy' emerged under colonialism, with the ritualistic Brahmanical caste hierarchy more or less matching the socioeconomic hierarchy derived from landholding.

On the top was created the locally dominating class consisting of Sarabarākāras (Khaṇ̣āyatas and Karaṇas) and the Brāhmaṇas who held large tracts of land free of tax or with light rent and thereby formed the local elite or 'local rich' (Ludden, 1990: 174). Below them was the 'dominant caste' (Pāikas or Khaṇdāyatas) that, in aggregate, occupied a major share of the cultivated land. The families and castes consisting of these classes were reminiscent of the pre-colonial system of power, and so continued to be considered by the villagers as the 'traditional' authority of the locality. The artisan and service castes that were in a 'jajmani' relationship with the landholding households were placed below them. At the lowest ladder were placed what the colonial government called the 'poorer and laboring classes' (Maddox Report), such as the 'low' caste Bāuris and Hạris, and the tribal Saora and Khondhas.

The British colonial policy brought about a breakdown of the 'system of entitlements'. In its place, it created a 'unitary caste hierarchy' which 'traditionalized' the privileged authority of the Brāhmanas, the local elites and the dominant caste. Village society therefore became stratified in a structure of dominance and hierarchy, along with the social formation of 'caste hierarchy', 'dominant caste' and 'jajmani system', and decontextualized from pre-colonial principles of community and kingship. The colonial state, with its centralized bureaucracy and military, functioned to guide society into reproducing the status quo of the newly 'traditionalized' social structure and extracting the agrarian surplus. This kind of Orientalist and stereotypical 'traditional' picture of India with a unitary caste hierarchy, where class defined by the amount of landholdings and Brahmanical caste hierarchy more or less overlapped at the village level, and the conqueror state existed above and outside society and extracted the agrarian surplus, became closest to reality during this early colonial period (Washbrook, 1981, 1988).

\subsection{Maturity of the colonial administration and commercialization of the agrarian economy}

The setup of the colonial administration became more or less complete in the latter half of the nineteenth century. At about the same time, the commercialization of the agricultural economy developed in India. The local 
society came to have a new dynamism. Revisionist historians such as Bayly (1983, 1988), Washbrook $(1981,1988,1990)$, and Stein $(1985,1989)$ correctly recognize the importance of the transformation from the midnineteenth century, but this should be taken as the second pivotal change after the first colonial impact of structural fragmentation.

In Orissa, in the development of the colonial economy, the surplus from villages, mainly rice, was taken from the hinterland to the towns; it was also exported by sea. ${ }^{18}$ The price of rice rose in Orissa in the latter half of the nineteenth century concomitantly with the commercialization of the agrarian economy. ${ }^{19}$

What was significant in relation to agricultural commercialization was the establishment of rights of sales of land. In Khurda, the right of occupancy granted to the cultivators by 1836 settlement accompanied the de facto right of transfer. Soon the selling and buying of land began spontaneously. The British government later admitted the right of transfer as a de jure right in 1874. ${ }^{20}$ With official recognition of the rights of transfer of land, the market value of the cultivated lands rose. The number of land transactions increased dramatically. ${ }^{21}$ Consequently, the movement of land ownership hastened. It was part of an economic colonial policy to 'enhance agrarian commercialization and its link to world trade' by establishing 'in law of private, alienable property' and by reinforcing 'class differentiation' among rural people (Stein, 1992: 17).

The classes of people who benefited most from commercialization of agriculture were mostly trader castes and landowners who succeeded in the agricultural business. If one compares the change of landholdings by caste in Table 3.5, then one notes a considerably higher rate of increase of landholding by Oil-presser (877.22 percent), Fisherman (753.46 percent), Potter (357.97 percent), Sweet-maker (184.33 percent), and Cowherd (174.18 percent) castes, aside from Brāhmaṇas (1261.67 percent). Many of these castes engaged in agricultural management using cheap labor, and also engaged in commercial and trade activities.

A few of them flourished as the 'new rich' class, having succeeded in accumulating wealth along with agricultural commercialization and gaining new private property. As the economic status of the new rich improved, the economic status of the traditional elite who were unable to cope with the change of the times worsened. The land ownership rate of the Khanḍayata caste, the presumed 'dominant caste', against other castes in Garh Manitri decreased from 59.49 percent to 42.92 percent between 1828-1830 and 1911 (Table 3.5). With the change in economic status, the new rich class also began to replace old local elites as Sarabarākāras (Tax-Collectors) under the colonial government. In Garh Manitri, the office of Sarabarākāra was occupied by the Chief, the Accountant and two Scribes at the beginning of colonization. However, the office of the Accountant and Scribes, who held 57 acres as jagir in total, was confiscated around 1878. The dramatic decrease of landholdings of the Scribe caste from 6.23 percent to 0.35 percent 
between 1828-1830 and 1911 must be regarded in this light (Table 3.5). The Chief had 47.828 acres of jagir, but in 1929 he was also dismissed from the office of Sarabarākāra. His land was confiscated. From that time, the office of Sarabarākāra in Garh Manitri (which consisted of four administrative villages) became the object of sale. The new rich, which included five Scribe castes, two Khaṇ̣āyata castes, one Sweet-maker, and one Oil-presser, with their newly acquired wealth saw it as investment opportunity and bought the office at auction in successive years. By attaining the post of Sarabarākāra, the new rich also acquired socio-ritual authority in local society including privileges in the community ritual of Rāmacaṇdi festival. ${ }^{22}$

Development of the commercialization of agriculture was related to class differentiation also in the sense of creating a destitute class. As cash transactions penetrated into agrarian economy and money lenders (mahäjan) became increasingly active in rural areas, mass scale indebtedness developed among petty peasants by the end of the nineteenth century. ${ }^{23}$ In this situation, the new rich class purchased or mortgaged lands from the poorer peasants who were in need of cash. This state of affairs led to the emergence of a 'proletarianized' landless laborer class (Mohapatra, 1990: 50; Pati, 1993: $14-7) .{ }^{24}$ The cheap agricultural laborers played an important part in the colonial agricultural management. The economic gap grew between rich people who had succeeded in taking advantage of the commercialization process and the landless class of agricultural laborers such as Hāri, Bāuri, and Saora who belonged to 'untouchable' and 'tribal' groups. ${ }^{25}$ This landless 'low' caste population had to work for the landowning class as bonded agricultural laborers, called haliā, who were 'engaged by the year and paid daily in kind'. ${ }^{26}$ The landholdings of Saora and Bāuri stalled at a very low level from 1828-1830 to 1911 (Table 3.5). In 1828-1830, Hāri used to own a considerable amount (24.320 acres) of cultivated land considering that they were treated as 'untouchables'. This was attributable to the heritage of the entitlement they used to have during the pre-colonial period. However, as the system of entitlements broke down, there was introduced ownership and alienability of land, with no more guarantee of the share of community resources. 'Free' individual ownership worked against the advantage of the discriminated castes. Land ownership of Hāri decreased by half (12.433 acres) by 1911 (Table 3.5). They had no other means but to work as bonded agricultural laborers for the landowning 'high' castes.

The predicament of the 'low' castes was worsened by the ecological changes under colonialism. The British government attempted to promote the clearing of forests for cultivation in the $1830 \mathrm{~s}$, and permitted the free use of forests. In doing so, they had sought to increase the taxable lands to enrich the government funds, ${ }^{27}$ but what actually happened instead was the indiscriminate cutting down of forest trees, the flow of timber into other regions, the selling of bamboo and firewood, and the development of unchecked slash-and-burn agriculture. The marketing of timber was related to the increased importance of timber as a commodity within the colonial 


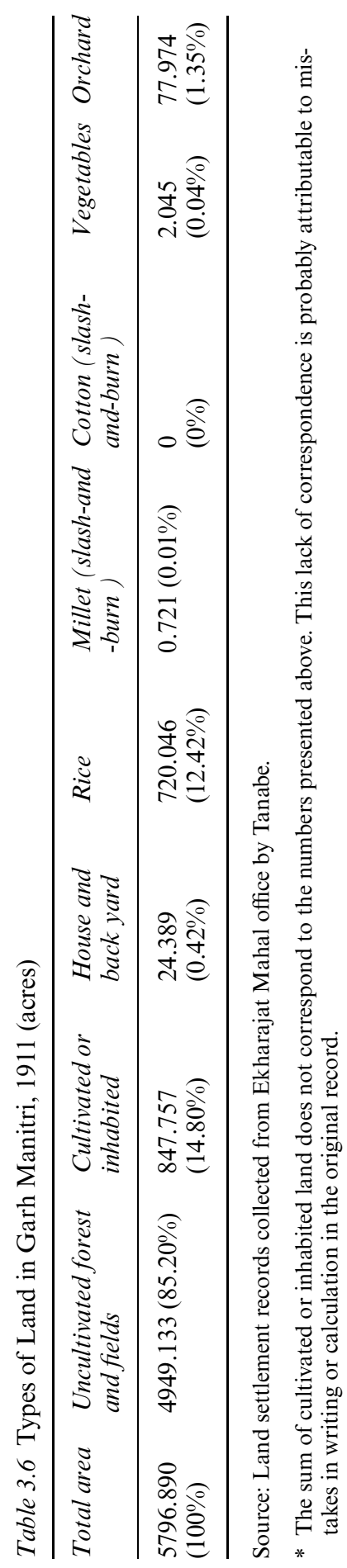


economy. By the 1870s, the situation was disastrous. The forests of Khurda region were almost depleted. ${ }^{28}$ Then, to restore the forests, the government banned slash-and-burn agriculture in $1871 .{ }^{29}$ Moreover in 1880 , all unsurveyed lands in Khurda became categorized as protected forests. ${ }^{30}$ They were placed under the charge of the Forest Department. The use of forests and waste lands was severely restricted.

Table 3.6 below shows land usage by produce in Manitri village in 1911. The almost total annihilation of slash-and-burn agriculture is noteworthy when compared to figures presented in Tables 3.1 and 3.2, showing land usage from 1829-1830. Barely any millet is grown at that point, although it had been an important food especially for 'lower' castes in pre-colonial times. The growing of raw cotton, which had been an important source of cash income for villagers, vanished because the production of cotton cloth stopped under colonial rule.

As a result of the banning and loss of slash-and-burn agriculture as a means of complementary subsistence, people were compelled to rely on products of plough-cultivated lands for their supply of agricultural products. The landholding of the paddy fields came to hold more importance because there was a concomitant decrease of other means of livelihood. By the latter half of the nineteenth century, inequities in the ownership of cultivated lands came to be reflected directly in the relations of domination in society. The tribal Saora and Bāuri particularly lost their means of production in the forest, such as hunting and gathering and shifting cultivation. Moreover, the degree to which they were dominated by the landowners as bonded agricultural laborers (hali $\bar{a})^{31}$ increased.

\section{Conclusion}

The system of entitlements in eighteenth century Orissa functioned as a mechanism of 'sociological adaptation' to agricultural risks. Diversity in the kinds of work, agricultural production and seasonal activities as well as the sharing of local products according to the percentage of entitlements functioned as a mechanism supporting the reduction and distribution of agricultural risks.

The institution of private land ownership rights under colonial rule, however, engendered the collapse of the entitlement system. The socioeconomic principle of 'participation and sharing' was replaced by the new principle of 'individual proprietorship'. The colonially constructed land tenure structure privileged the local elite of Brāhmaṇas and Karaṇas (Scribes) and the dominant caste of Khaṇāyatas (Peasant-militia), thereby creating a 'unitary caste hierarchy' in which the Brahmanical ritual hierarchy overlapped with the economic landholding hierarchy. It is noteworthy that an aspect of continuity in the local power structure existed, but the latter structure was a crude shadow of the intricate totality of the structure of dominance and hierarchy based on colonial privileges granted to the Brāhmaṇas and the local elite. 
The second phase of social transformation under colonialism came with the commercialization of agriculture in the latter half of the nineteenth century. The 'traditionalized' structure of dominance established in the early nineteenth century went through reshuffling as class differentiation developed. There arose the 'new rich', on the one hand, who were successful in amassing wealth in the new economic opportunities. They were able to take risks under the colonial economy. On the other hand were poorer peasants tyrannized by debt. Much of the 'low' caste population became landless and 'proletarianized' as bonded agricultural laborers. They were actually the ones who were forced to bear the costs of the new risks.

The breakdown of the system of entitlements, introduction of proprietary rights to land including alienability, and commercialization of agriculture meant that there was more economic freedom for individual households for taking risks, but at the cost of livelihood security, especially for underprivileged people. The new system of free competition often worked in favor of its most rich and powerful participants. In Khurda, persons in lower castes were forced to sell their land plots, leaving many entirely deprived of their landholdings. Furthermore, in addition to being denied their share of the community's output that had been guaranteed under the entitlement system, such individuals were forced to labor under harsh conditions as agricultural workers supporting the landowning classes. They also often suffered from crushing indebtedness from money lenders.

It was under such conditions of a loss of socioeconomic security that the catastrophic famine of 1866 took place in coastal Orissa, when nearly onethird of the population in coastal areas was estimated as having died (Pattnaik, 1980; Mohapatra, 1990: 48; Sugimoto, 2007). This event constituted a turning point in the history of Orissa when the following decade saw the establishment of a 'public sphere' in the form of several publications and voluntary associations that promoted developmental, educational, and other reform activities that later served as the basis of the Oriya nationalist movement. The 'sociological adaptation' was no longer functioning. People began to aspire for an 'Oriya nation' and an 'Indian nation' as a new system for security.

\section{Abbreviations}

Ewer Report

From W. Ewer to W. B. Bayley, Calcutta, 13 May 1818, in Selections from the Correspondence on the Settlement of Khoorda Estate in the District of Pooree Vol. I

Hota Report

Hota, N. R. Final Report on Ekharajat Mahal 1953 to 1965. Cuttack: Government Press, 1972.

Maddox Report

Maddox, S. L. Final Report on the Survey and Settlement of the Province of Orissa (Temporary 
Mishra Report

Rate Report

Selections I

Taylor Report [1871]

Taylor Report [1877]

Taylor Report [1886]

Wilkinson Report
Settled Areas) 1890 to 1900 A.D., vol. 1. Reprinted under the authority of Board of Revenue, Orissa.

Mishra, R. K. Final Report on the Revision settlement of 1952-1962 AD of Khurda. Cuttack: Orissa Government Press, 1971.

'The Rate Report of the Settlement Officer', From W.C. Taylor to the Collector of Puri, Khordah, 30th November 1879, in Selections from the Correspondence on the Settlement of Khoorda Estate in the District of Pooree Vol. II

Selections from the Correspondence on the Settlement of Khoorda Estate in the District of Pooree Vol. I

From W. C. Taylor to the Collector of Pooree, 6 April 1871, in Report on the Administration of the Khorda Sub-division for 1870-1871

From W. C. Taylor to the Collector of Pooree, 21 May 1877, in Selections from the Correspondence on the Settlement of Khoorda Estate in the District of Pooree Vol. I

From W. C. Taylor to the Collector of Pooree, 20 September 1886, in Completion Report on the Survey and Settlement of the Khoorda Estate

From W. Wilkinson to the Commissioner for the 19th Division, 24 October 1836, in Selections from the Correspondence on the Settlement of Khoorda Estate in the District of Pooree Vol. I

\section{Notes}

1 The 'system of entitlements' here is based on the same principle as the 'Vatan System' in the Deccan suggested by Kotani $(1996,2002)$ and the 'Mirasi' System in South India suggested by Mizushima (1996, 2006), although details and emphasis differ.

2 This can be surmised from the present population pattern. They are said to be from the kingdom of Athagarh and to be the descendants of a Brāhmaña father and a Sweet-maker mother.

3 Peasants residing in this area reportedly regarded 'chandina' (sic) as derogatory (Rate Report, para.210, p.84).

4 'Khañja supplies' consisted of various items such as cotton fields (toila khañjā), mango trees, yoghurt, and pots. They also included various tolls for festival occasions.

5 One kāhana was equal to about a quarter of a rupee in the late eighteenth century (De, 1952; Heimann, 1980; Perlin, 1987: 367; Vogel, 1991: 252). The cowry value dropped dramatically after colonization. 1 kāhāna $=16$ paṇa = 320 ganḍa $=1280$ kada $\bar{a}=1280$ kauri (cowry).

6 Tanabe $(2005,2010)$ presents details of the system of entitlements in Garh Manitri, Khurda. 
7 For the concepts of 'geosphere', 'biosphere', and 'human society' in the 'humanosphere', see Sugihara (2013).

8 Koji Tanaka, in discussion of 'agronomic adaptation' and 'technological adaptation', suggests alternative terminology as follows: 'environment-adaptive technology' instead of agronomic adaptation, and 'environment-formative technology' instead of technological adaptation. He says,

In the premodern period, there were two types of technologies pitted against nature: one utilized the natural environment as it was without making any modification or change to the environment; and the other worked actively upon the natural environment to modify it and form a new environment for rice cultivation .

(Tanaka, 1991: 565)

However, because agronomic adaptation is related to selective breeding and consequently to adjustment in the biospheric environment, it is not without modification in the natural environment in a strict sense. The concept of 'sociological adaptation' suggested here is truly 'environment-adaptive' while adjusting human society to enable it to cope with unpredictable natural conditions.

9 The word Sarabarākāra as well as its system was a new import into the area by the British. From Ewer Report, para. 177.

10 Since the British did not understand the mechanism of the pre-colonial system of entitlements, they understood the land part of the share as jagir or tax-free land. However, in fact, as shown herein, jagir (jägiri), or tax-free land, was only granted to ministers and generals who were state-level high officers above the fort unit level. In this chapter, the word jagir is used as the British used the term.

11 Rate Report, part I, para. 8-11.

12 W. Trower wrote the following in 1813:

It appears evident that a system of extreme tyranny, violence and oppression has existed, which has proved ruinous to this once flourishing country by the consequent desertion of a great proportion of the cultivators of the soil. ... I am concerned to state too and [sic] that this system is to be dated from the conquest of Khurda by the British troops...

W. Trower, Collector of Cuttack to G. Warde, Secretary to the Member, Board of Revenue, dated 12.11.1813 (quoted in De, 1962: 8).

13 Ewer Report. Also see reports collected in S.C. De (De, 1961).

14 Rate Report, part 1, para. 11.

15 Rate Report, part 1, para. 15.

16 Wilkinson Report, para 11, p. 126. Rate Report, part 2, para. 61-3, p. 51.

17 Bayly explains how the social power of the rural dominant castes of north India was reproduced over the last 250 years in its specific forms of interaction with the world economy: 'power continues to encompass economy' (Bayly, 1990: 139). At least in Orissa, however, the social power of the 'dominant caste' has always been under contest and change. Although the author agrees with Bayly on the relative continuity of their social authority, one can say that it is also necessary to devote attention to changes in their status especially at the time of colonization, as described herein, along with the commercialization of the rural economy from the mid-nineteenth century discussed later.

18 It is said that 'exports by sea in 1897-1898 came to 26 lakhs of maunds' (Maddox Report, p.129). 1 maund $=82.14 \mathrm{lbs}, 1 \mathrm{lakh}=100,000$

19 Maddox Report I, p.121.

20 Rate Report, part 2 para. 163, p.71. 
21 Rate Report, part 2 para. 166, p.72.

22 Tanabe $(1999,2003)$ explains the relation of the Rāmacaṇ̣̂ festival to the local structure of authority and privileges.

23 Maddox Report, pp. 126-32.

24 Pati describes 'the growth of a money-economy' and 'social differentiation' as an effect of the land settlement (1993: 14-16).

25 Yanagisawa (1996) points out a tendency in colonial South India for the lower strata of people, such as the 'untouchables', to acquire new land and to become independent cultivators, but this does not apply to Garh Manitri at least. Yanagisawa's situation might be related to the migration of richer sections to urban areas, thereby creating space for land ownership by the 'lower strata'. Further empirical research must be done of the historical changes in land ownership in villages in India to evaluate the meaning of colonial changes for the 'lower' caste population.

26 Maddox Report, p. 136. See the same page for details of payment.

27 Wilkinson Report, para. 17, p.131.

28 Taylor Report [1877], para. 69-70, pp. 176-77.

29 Taylor Report [1877], para. 72, p.177; Taylor Report [1871].

30 Taylor Report [1886], part II, para. 369, p. 132.

31 See Maddox Report, p.136.

\section{References}

Appadurai, A. (1993). "Number in the Colonial Imagination," In Breckenridge, C. and P. van der Veer eds., Orientalism and the Postcolonial Predicament: Perspectives on South Asia. Philadelphia, PA: University of Pennsylvania Press, pp. 314-39.

Bayly, C. A. (1983). Rulers, Townsmen and Bazaars: North Indian Society in the Age of British Expansion, 1770-1870. Cambridge: Cambridge University Press.

(1988). Indian Society and the Making of the British Empire. Cambridge \& New York: Cambridge University Press.

(1990). "Indigenous Social Formations and the 'World System': North India since C. 1700," In Bose, S. ed., South Asia and World Capitalism. New Delhi: Oxford University Press, pp. 112-39.

Cohn, B. S. (1987). "The Census, Social Structure and Objectification in South Asia," In An Anthropologist among the Historians and Other Essays. Oxford: Oxford University Press, pp. 224-54.

De, S. C. (1952). "The Cowry Currency in India," Orissa Historical Research Journal, vol. 1 (1), pp. 1-10.

(ed.) (1961). A Guide to Orissan Records II. Bhubaneshwar: The State Archives of Orissa.

(ed.) (1962). A Guide to Orissan Records III. Bhubaneswar: The State Archives of Orissa.

Gadgil, M. and R. Guha (1992). This Fissured Land: An Ecological History of India. New Delhi: Oxford University Press.

Grove, R., V. Damodaran and S. Sangwan (eds.) (1998). Nature and the Orient: The Environmental History of South and Southeast Asia. New Delhi: Oxford University Press.

Guha, S. (1999a). "Communities, Kings and Woodlands: Historical Reflection of Joint Forest Management," In Jeffery, R. and N. Sundar eds., A New Moral Economy for 
India's Forests?: Discourse of Community and Participation. New Delhi: Sage, pp. $55-70$.

. (1999b). Environment and Ethnicity in India, 1200-1991. New York: Cambridge University Press.

Heimann, J. (1980). "Small Change and Ballast: Cowry Trade and Usage as an Example of Indian Ocean Economic History," South Asia: Journal of South Asian Studies, vol. 3 (1), pp. 48-69.

Ishii, Y. (1978). "History and Rice-Growing," Peter and Stephanie Hawkes (trans.), In Ishii, Y. ed., Thailand: A Rice-Growing Society. Honolulu: University Press of Hawaii, pp. 15-39.

Kotani, H. (1996). "The Vatan-System in the Sixteenth-Eighteenth Century Deccan: Towards a New Concept of Indian Feudalism," In Jha, D. N. ed., Society and Ideology in India: Essays in Honour of Professor R. S. Sharma. Delhi: Munshiram Manoharlal Publishers Pvt Ltd., pp. 249-68.

. (2002). Western India in Historical Transition: Seventeenth to Early Twentieth Centuries. New Delhi: Manohar.

Ludden, D. (1990). "World Economy and Village India, 1600-1900: Exploring the Agrarian History of Capitalism," In Bose, S. ed., South Asia and World Capitalism. New Delhi: Oxford University Press, pp. 159-77.

Mehta, U. S. (1999). Liberalism and Empire: A Study in Nineteenth-century British Liberal Thought. Chicago, IL: University of Chicago Press.

Mizushima, T. (1996). "The Mirasi System and Local Society in Pre-Colonial South India,” In Peter, R., K. Sugihara and H. Yanagisawa eds., Local Agrarian Societies in Colonial India: Japanese Perspectives. London: Curzon Press, pp. 77-145.

- (2006). "The Mirasi System as Social Grammar: State, Local Society, and Raiyat in 18th - 19th Century South India," In Kimura, M. and A. Tanabe eds., The State in India: Past and Present. New Delhi: Oxford University Press, pp. 140-201.

Mohapatra, B. N. (1990). The Politics of Oriya Nationalism, 1903-1936. D. Phil., Oxford University.

Pati, B. (1993). Resisting Domination: Peasants, Tribals, and the National Movement in Orissa, 1920-50. New Delhi: Manohar.

Pattnaik, G. (1980). The Famine and Some Aspects of the British Economic Policy in Orissa 1866-1905. Cuttack: Vidyapuri.

Perlin, F. (1987). "Money-Use in Late Pre-Colonial India and the International Trade in Currency Media," In Richards, J. F. ed., The Imperial Monetary System of Mughal India. New Delhi: Oxford University Press, pp. 232-373.

Sinha, S., S. Gururani and B. Greenberg (1997). "The 'New Traditionalist' Discourse of Indian Enviromentalism," Journal of Peasant Studies, vol. 24 (3), pp. 65-99.

Stein, B. (1985). "State Formation and Economy Reconsidered," Modern Asian Studies, vol. 14 (3), pp. 387-413.

. (1989). "Eighteenth Century India: Another View," Studies in History (N.s.), vol. 5 (1), pp. 1-26.

(1992). "Introduction," In Stein, B. ed., The Making of Agrarian Policy in British India 1770-1900. New Delhi: Oxford University Press, pp. 1-32.

Sterling, A. (1904 (1846)). An Account (Geographical, Statistical, and Historical) of Orissa Proper or Cuttack with Appendices. Calcutta: Bengal Secretariat Press.

Sugihara, K. (2013). "Sustainable Humanosphere in Global History," The Newsletter, International Institute for Asian Studies, vol. 66, pp. 26-27. 
Sugimoto, K. (2007). Oriya Nashonarizumu no Keisei to Henyo: Eiryo Indo Orissa-shu no Sosetsu ni Itaru Aidentiti to Kyokai no Poritikusu (in Japanese: The Formation and Transformation of Oriya Nationalism: Politics of Identity and Boundary Leading to Establishment of the State of Orissa in British India). Tokyo: Tokai University Press.

Tanabe, A. (1999). "The Transformation of Śakti: Gender and Sexuality in the Festival of Goddess Ramachandi," In Tanaka, M. and M. Tachikawa eds., Living with Śakti: Gender, Sexuality and Religion in South Asia. Osaka: National Museum of Ethnology, pp. 137-68.

. (2003). "The Sacrificer State and Sacrificial Community: Kingship in Early Modern Khurda, Orissa Seen through a Local Ritual," In Berkemer, G. and M. Frenz eds., Sharing Sovereignty: The Little Kingdom in South Asia. Berlin: Klaus Schwarz Verlag, pp. 115-35.

. (2005). "The System of Entitlements in Eighteenth-century Khurda, Orissa: Reconsideration of 'Caste' and 'Community' in Late Pre-colonial India," South Asia: Journal of South Asian Studies, vol. 28 (3), pp. 345-85.

- (2010). Kasuto to Byodosei: Indo Shakai no Rekishi Jinruigaku (in Japanese: Caste and Equality: Historical Anthropology of Local Society and Vernacular Democracy in India). Tokyo: The University of Tokyo Press.

. (2020). "Genealogies of the 'Paika Rebellion': Heterogeneities and Linkages," International Journal of Asian Studies, vol. 17 (1), pp. 1-18.

Tanaka, K. (1991). "A Note on Typology and Evolution of Asian Rice Culture: Toward A Comparative Study of the Historical Development of Rice Culture in Tropical and Temperate Asia,” Southeast Asian Studies, vol. 28 (4), pp. 563-73.

Vogel, H. U. (1991). "Cowry Trade and Its Role in the Economy of Yunnan, the Ninth to the Middle of the Seventeenth Century," In Ptak, R. and D. Rothermund eds., Emporia, Commodities and Entrepreneurs in Asian Maritime Trade, C. 1400-1750. Stuttgart: Franz Steiner Verlag, pp. 231-62.

Wakimura, K. (2009). "Kinben Kamumei wa Okottanoka? Indoshi ni Okeru 'Tochi Kishoka' (in Japanese: Was There Industrious Revolution?: Land Scarcity in Indian History)," In Oshima, M. ed., Tochi Kishoka to Kinben Kakumei no Hikakushi (Comprative History of Land Scarcity and Industrious Revolution). Kyoto: Minerva Shobo, pp. 251-74.

Washbrook, D. (1981). "Law, State and Agrarian Society in Colonial India," Modern Asian Studies, vol. 15 (3), pp. 649-721.

. (1988). "Progress and Problems: South Asian Economic and Social History C.1720-1860," Modern Asian Studies, vol. 22 (1), pp. 57-96.

. (1990). "South Asia, the World System and World Capitalism," Journal of Asian Studies, vol. 49 (3), pp. 479-508.

. (1993). "Land and Labour in Late Eighteenth-Century South India: The

Golden Age of Pariah?," In Peter, R. ed., Dalit Movements and the Meanings of Labour in India. New Delhi, pp. 68-86.

Yanagisawa, H. (1996). A Century of Change: Caste and Irrigated Lands in Tamilnadu 1860s-1970s. New Delhi: Manohar. 


\title{
4 Bengal agrarian society during late colonial rule
}

\section{The development of the Sundarbans}

\author{
Shinkichi Taniguchi
}

PROFESSOR EMERITUS, HITOTSUBASHI UNIVERSITY

\section{Introduction}

Looking at the historical transformation of Bengal agrarian society during late colonial period, it is clear that economic growth of some kind took place. The reclamation of the Sundarbans, extensive forests that lie along the southern coast of the Ganges delta, was a key part of this. Several questions regarding the Sundarban initiative are addressed in this chapter, including, why did the colonial government push forward the reclamation of the Sundarbans? What was the significance of this process for the economy of colonial Bengal? How did it impact upon social relations? Was the newly created agrarian society in the Sundarbans completely different from the one prevailing outside? And how did this new society continue to affect Bengal agriculture? ${ }^{1}$

A remarkable indicator of economic growth in Bengal is the marked trend of population growth recorded by the decennial population censuses from 1881 (Figure $4.1 \&$ Table 4.1 ). ${ }^{2}$ Behind this growth and the transformation of Bengal agriculture was an important driving force: the rapid expansion of the world market for jute. From the late 1860s to 1929, there was an almost constant rise in agricultural prices. ${ }^{3}$ This created larger incomes for people who depended upon agriculture, including grain merchants, traders of various commodities, moneylenders, boatmen, landlords, intermediatetenure holders, rich peasants, ordinary peasants, some artisans, tea-planters, and owners of jute presses. Crucially, in relation to this study, the enhanced prospect of profits induced moneyed men of various kinds to invest in the reclamation of arable waste lands, particularly those in the Sundarban forests. Also, the long-term increase in the price of commercial crops encouraged changes in cropping patterns. Many peasants increased their cultivation of profitable crops such as jute, sugarcane, mulberry, betel nuts, betel leaf, and rice. This was often done at the expense of growing food grains for home consumption. Consequently, a great shift in crop production took place in many parts of the Bengal plains. This change more or less dominated the pattern of development in Bengal agriculture up to 1929. 


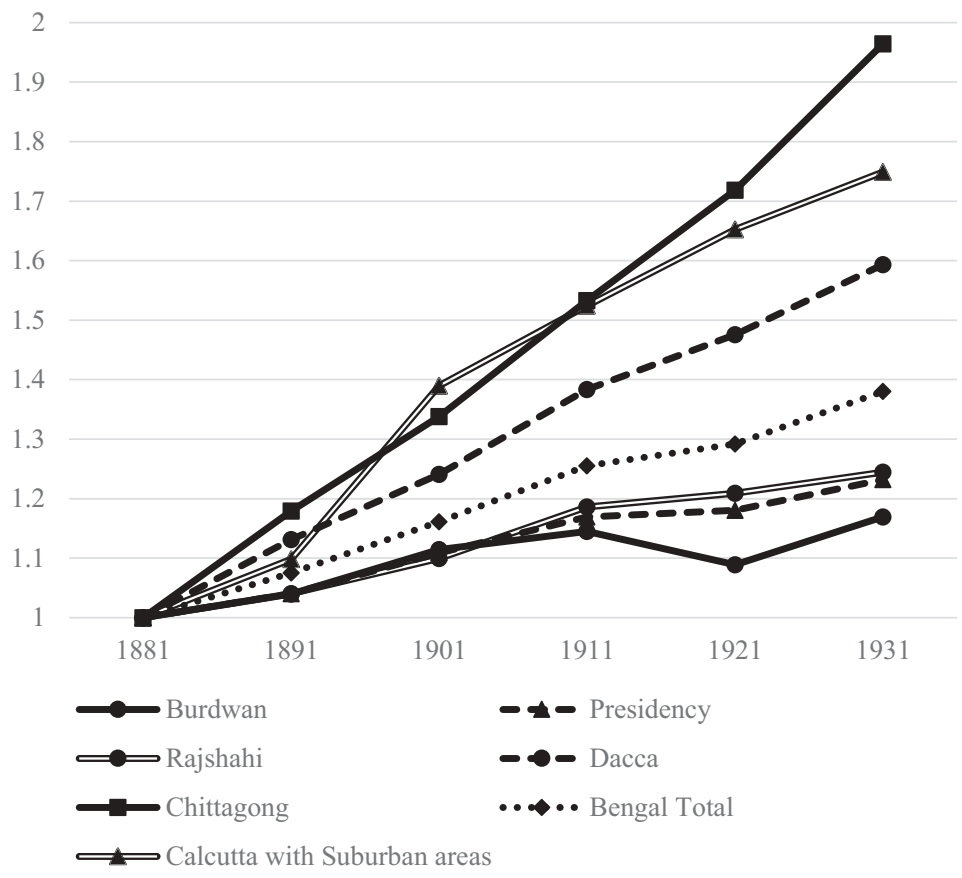

Figure 4.1 Population Growth of Lower Bengal (1881-1931)

Source: Various volumes of Census of Bengal, 1881-1931.

Note: Spelling of divisions follows the original.

Table 4.1 Population Growth of Lower Bengal (1881-1931)

\begin{tabular}{lrrrrrr}
\hline Divisions & 1881 & \multicolumn{1}{l}{1891} & \multicolumn{1}{l}{1901} & \multicolumn{1}{l}{1911} & \multicolumn{1}{l}{1921} & \multicolumn{1}{l}{1931} \\
\hline Burdwan & $7,393,954$ & $7,688,818$ & $8,240,076$ & $8,467,314$ & $8,050,642$ & $8,647,189$ \\
Presidency & $8,204,912$ & $8,535,126$ & $9,096,572$ & $9,592,561$ & $9,684,690$ & $10,108,984$ \\
Rajshahi & $9,046,847$ & $9,412,974$ & $9,946,163$ & $10,731,254$ & $10,938,153$ & $11,258,952$ \\
Dacca & $8,700,939$ & $9,844,127$ & $10,793,988$ & $12,037,649$ & $12,837,311$ & $13,864,104$ \\
Chittagong & $3,669,685$ & $4,327,523$ & $4,911,056$ & $5,624,104$ & $6,304,961$ & $7,208,864$ \\
Bengal Total & $37,016,337$ & $39,808,568$ & $42,987,855$ & $46,452,882$ & $47,815,757$ & $51,088,093$ \\
Calcutta & & & & & & \\
with Subur- & 684,658 & 751,985 & 951,340 & $1,043,307$ & $1,131,146$ & $1,197,489$ \\
ban areas & & & & & &
\end{tabular}

Source: Various volumes of Census of Bengal, 1881-1931.

Note: Spelling of divisions follows the original. 
Expansion of production was not limited to the agricultural sector. Industrial production, including coal and steel, also increased. In tandem, modern transportation systems, especially railways, spread across the region, connecting remote rural areas with Calcutta and other urban centers. The latter rapidly swelled to accommodate increasing numbers of people engaged in trade, industry, commerce, transportation, and administration. The graph in Figure 4.1 shows the surge in Calcutta's population. However, this urban expansion was not restricted to Calcutta. Many new towns and cities emerged, and other older commercial centers also grew. This visible expansion underscores the flourishing of the Bengal economy in the late nineteenth century, and it was the newly reclaimed Sundarban paddy-fields that supported it, fulfilling the greatly increased urban demand for food-grains. Thus, the Sundarban reclamation played a vital role in the transformation of the Bengal colonial economy. The significance of this role and its limitations will be further explored in this chapter.

\section{Sundarban reclamation and its social impact}

The Sundarban reclamation had a far reaching impact; its land tenure, its influence on agrarian society, its products, and its trade with Calcutta and other markets were closely connected with the colonial transformation of Bengal economy as a whole.

\subsection{The Sundarbans}

The Sundarbans was a series of vast forests grown on lands largely formed by alluvial deposits carried by the Ganges, the Brahmaputra, and the Megna (Map 4.1). It also partly owed its existence to the materials brought by the ocean's tidal movements at the mouth of the Ganges delta. The Sundarbans area extends 165 miles from east to west and 81 miles from north to south. Its eastern boundary is the Hughli, the western boundary the Megna, and the southern boundary the coast of the Bay of Bengal. The forests' total area was 7,532.5 square miles in the first half of the $1870 \mathrm{~s},{ }^{4}$ and composed of trees and shrubs of various kinds, with rivers, creeks, lakes, marshes, sand-bars, and islands. They served as a buffer from the onslaught of deadly tidal waves, thereby protecting residents, cattle, and crops.

Until reclamation gained momentum in the mid-nineteenth century, the Sundarbans was the habitat of wild animals such as tigers, wild pigs, crocodiles, deer, and rhinoceroses. Only woodcutters, gatherers of forest products, fishermen, salt-manufacturers, and gangs of robbers (dakats) dared to enter the forests. People venturing into the forests were invariably accompanied by a Muslim mendicant (fakir) who was believed to possess magical powers for deterring tigers.

Under the Permanent Settlement of 1793, all lands in Bengal were divided into either permanently settled or temporarily settled areas. Major 


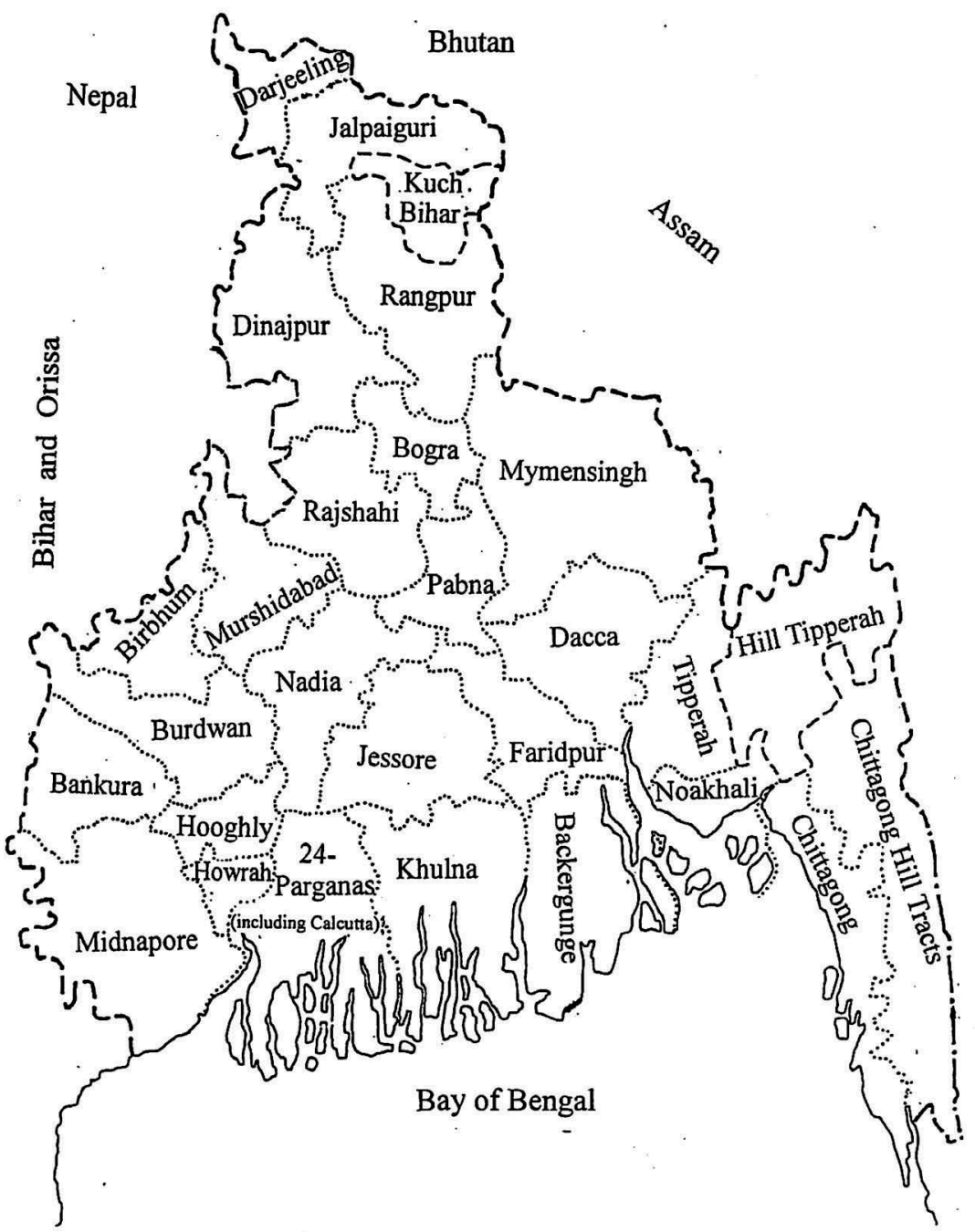

Map 4.1 Bengal in 1901

Source: Report on the Census of Bengal, 1901. Note: Spelling of the district names follows the original.

parts of Bengal became a permanently settled area where landlords (zamindars) were acknowledged as proprietors of the estates under their control on condition of paying permanently fixed land revenue punctually to the government. However, the government could not find anyone willing to pay 


\section{0}

Shinkichi Taniguchi

the revenues for the Sundarban tracts, so they were placed under the direct control of the government and became classified as temporary settlement areas. These forests, which formed southern parts of the 24-Parganas, Jessore, ${ }^{5}$ and Bakarganj districts, were placed under the management of the respective district officers (Map 4.2). Because the area produced no revenue for the state, the government wanted to encourage reclamation by granting advantageous leases (developmental leases). Although the goal of the policy was ostensibly the promotion of reclamation, it is perhaps too naïve to consider it as a sole objective. The possibility of reclaiming vast tracts of land under advantageous conditions soon became a target for lucrative speculation.

The southernmost parts of the Sundarbans had abundant tall trees, which served as a breakwater. In fact, people used to preserve a sufficient breadth of the forests carefully to protect life and property from damage that might result from the cyclones and tidal waves. ${ }^{6}$ However, as will be seen later, this protective measure began to disappear as forest clearance spread.

\subsection{Sundarban reclamation and its impact upon the Bengal economy}

The first attempt at reclaiming the Sundarbans was made by C. Russell, the Collector General of the 24 Parganas district in 1770. He granted leases for reclamation and the new fields were called the Patitabadi taluks. ${ }^{7}$ The next attempt was made by T. Henckell, the judge and magistrate of the Jessore district, in 1786. He intended to grant Sundarban leases directly to cultivators, and further argued that as the Sundarban area was free from drought, the supply of rice therefrom could be a reliable measure against famine. $\mathrm{He}$ constructed three market places as centers for reclamation activities and took necessary measures to ensure the safety of boats carrying food-grains from the eastern districts of Bengal to Calcutta through the jungles of the Sundarbans. Cultivation expanded from the surrounding areas of these market places and subsequently extended along both sides of the rivers and water-courses. One of the three markets, Henckellganj, became an important food-grain market in the district.

However, Henckell's vision of extending the reclamation did not materialize; neighboring zamindars strongly opposed his plans. They claimed that their estates extended to the seashore, and therefore the whole area of the Sundarbans should belong not to the Company's government but to them. They raised a number of suits against the Company, while violently pressuring lessees to leave. The zamindars' resistance put an end to Henckell's project. Almost all leases granted by Henckell had disappeared by 1792: only 16 remained. The leases that survived the zamindars' tenacious opposition were called Henckell's taluks. ${ }^{8}$ An interesting fact came to light at the time of a village boundary survey conducted in the 1850s. The survey revealed that the actual size of Henckell's taluks exceeded a few thousand acres, as the holders had secretly extended their property through the illegal 


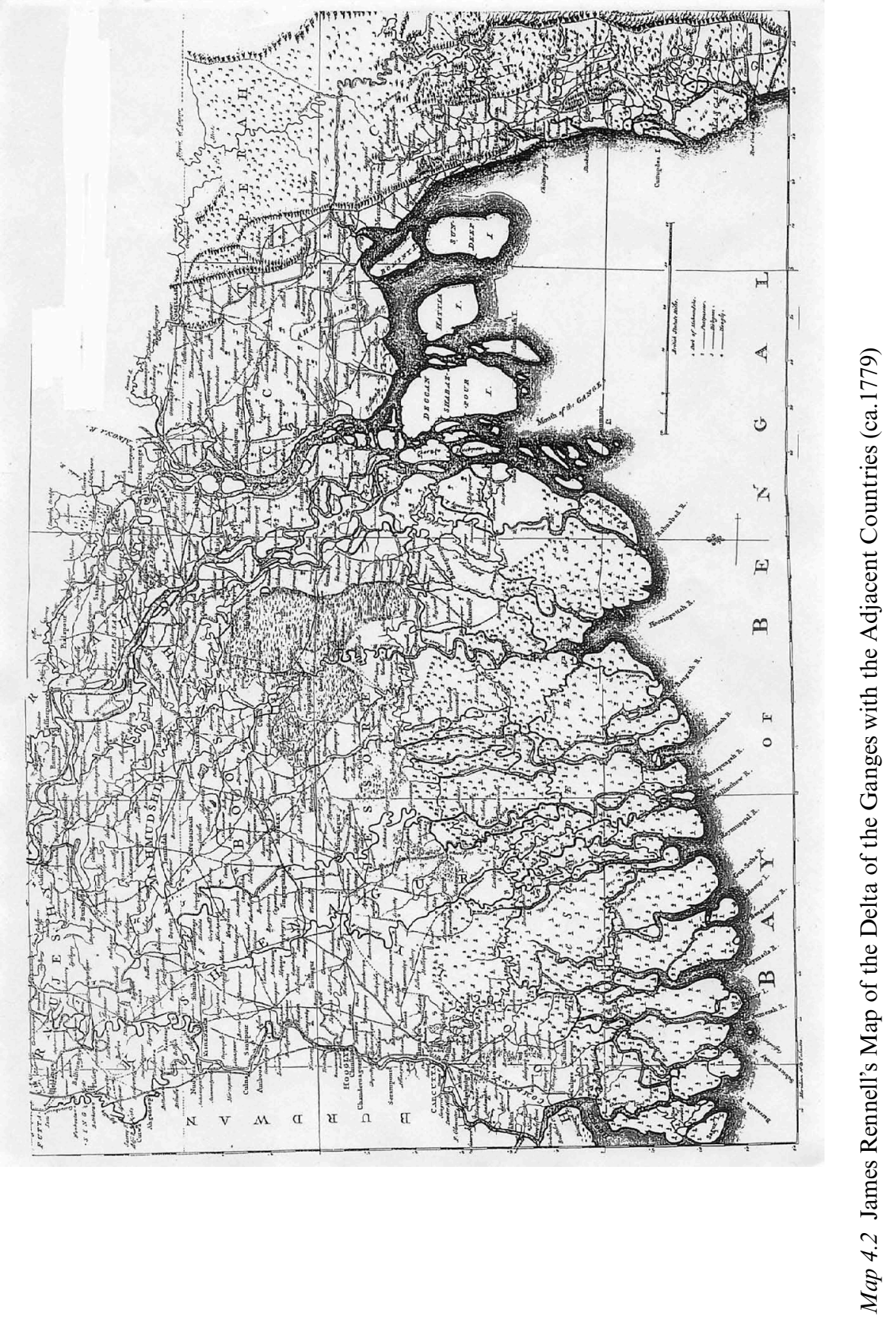




\section{2}

Shinkichi Taniguchi

reclamation of government lands. ${ }^{9}$ This suggests that some of the 'ordinary peasants' who obtained leases under Henckell's scheme in the late 1780s were, in fact, influential personages who obtained the grants using fictitious names (benamis).

Under the Mughal regime, it is to be added, people freely reclaimed jungles, unoccupied riverbank areas, and islands. Only after the reclamation was complete did they apply for a permit, which was readily granted. Consequently, the first clearer of the jungle, called the Janglebari talukdar, became the holder of the reclaimed land with special rights to it. In the early days of British rule, however, the ownership of Sundarban jungles was not clearly defined. Naturally, confusion and protest occurred when the British government claimed ownership of all lands in the Sundarbans. Such a claim was definitely considered an infringement on the generally accepted customary right of the first clearers. Faced with strong resistance from the zamindars and small talukdars, the Company's government had to somehow establish its claim over the unoccupied jungles of the Sundarbans through judicial and legislative processes. In order to establish the government's right over them, it was important to fix the boundaries of the Sundarban forests through survey and measurement, a laborious and time-consuming process. In fact, it took nearly 40 years for the government to finally establish its claim. In the meantime, the office of the Sundarbans Commissioner was set up at Alipur, a suburb of Calcutta, in 1816. All authority relating to the Sundarbans was transferred to this office. In 1831, the final versions of the boundary maps were published and with the completion of these maps, the zamindars' resistance at last came to an end.

Until 1830, there was no uniform rule for granting development leases. The European residents in Calcutta applied for the Sundarban leases from time to time, and they were given these under ad hoc rules. Usually, the grantees of the lease were requested to clear a specific proportion of the leased tracts within a fixed period as stipulated in the contracts. If they failed to realize this condition, the grants were to be invalidated. Between 1830 and 1835, 110 leases with a total area of 551,520 acres were allocated in the districts of the 24-Parganas and Jessore. However, it is difficult to ascertain to what extent the jungles within the granted tracts were actually brought into cultivation. ${ }^{10}$

An outstanding case of Sundarban reclamation by Europeans may be mentioned here. In 1849, Messrs. R. and T. H. Morrell obtained three Sundarban leases covering a vast area on the river Baleswar in the Jessore district. First, Morrell built a market town called Morrellganj on the Baleswar River and he himself lived there. Under his leadership, reclamation of the tracts around the market place progressed rapidly. By 1851, more than 10,000 laborers were employed. Forests were cleared in nine-mile-wide swathes along the river. Many of the laborers who reclaimed the area settled there and became permanent cultivators. In 10 years, Morrell reclaimed 
$60,000-65,000$ bighas $(18,000-19,500$ acres $)$ of forests and turned them into fertile agricultural land with a market value of $£ 80,000-100,000$. He rented out the cultivatable land at the fixed rate of one rupee two anas per bigha. He opened a police station, a sub-registration office, and a dispensary near the market, which became the largest in the Sundarbans. Prosperous villages sprung up here and there within the tract, and many cultivators settled there. Consequently, Morrell's lease turned out to be a rich granary in a short time. ${ }^{11}$ Such success as his was, however, an exception rather than the rule.

In the Sundarbans, cultivator colonies were often struck by fierce cyclones. The Sundarbans was situated at a low altitude and residential sites and fields were only one or two feet above the sea-level. When cyclones came, high storm surges ran up the rivers, topped the banks, and rushed into the plains of the hinterland. Flood waters destroyed houses, embankments, and agricultural fields along with their grain stocks. Inhabitants' lives were also lost, along with their cattle. Peasants were often deprived of their family, home, agricultural stock, and other property. Moreover, their fields incurred severe damage because of the inflow of salt water from the sea. Achievements won by many years of hard work were easily lost in one blow.

Census reports testify to the shocking damage caused by the huge tidal waves of 1822 and 1876 in the deltaic districts of east Bengal. The tidal wave of 1822 and the outbreak of epidemics that followed greatly reduced the Bakarganj population. Agricultural production decreased considerably and the ensuing epidemics exacerbated the situation. Drinking water became contaminated. Fields flooded by the salt water became useless. The population and agriculture reportedly took 20 years to recover in the Bakarganj district. The region was subject to similar destruction again in 1845 .

The next 30 years passed peacefully, and the population and agriculture recovered rapidly. However, a cyclone struck the districts of Bakarganj, Noakhali, and Chittagong in 1876. This time, the Meghna's periodic reverse flow (the Bore) and the cyclone coincided, and 3,000 square miles of the deltaic plains were inundated. The number of human victims soared to 200,000. A detailed survey conducted by the government officers in the Bakarganj district shortly after the calamity found that 74,000 people had been drowned. Another 42,000 people died of the cholera that followed. The total population of the affected area was 460,000 , one-fourth of whom perished. Large tracts of newly reclaimed lands were thrown out of cultivation. Many grantees fell into arrears of paying land revenue. As a result, a number of Sundarban grants were sold at public auction. ${ }^{12}$

In the 24 Parganas district, the Sagar Island reclamation project started early and proceeded smoothly until 1833, when strong winds and water inundation severely interrupted it. This island was buffeted by cyclones again in 1842 and 1848. Furthermore, in 1864, large tidal waves destroyed embankments, killing three-fourths of all the inhabitants (4,137 people). Soon after that, a cyclone struck the island in 1867. The government at last 
decided that people should be allowed to live on the island, but only within one mile of adequate shelter. ${ }^{13}$

The government could not ignore such repeated devastating calamities. The Sundarban development policy had to change in response. Richard Temple, the Lieutenant Governor of Bengal (1874-1877), argued that the Sundarban forests were important not only for the supply of rice, but for firewood and timber. They also provided vital protection for those living in deltaic districts as well as a habitat for wild animals, rare plants and trees, and other valuable materials. He ordered the Conservator of Forests in Bengal to undertake a survey of the condition of natural resources in the Sundarban forests. The Conservator reported that the Sundarban area was already over-developed. Based on that report, Temple established the Sundarbans Forest Division in 1874 and decided to create reserved forests, the reclamation of which was to be restricted.

He assigned 1,199 square miles of forests in the Sundarbans as reserved forests. ${ }^{14}$ These extended further as time passed. By the beginning of the twentieth century, 2,081 square miles were designated as reserved forests in the district of Khulna alone. Every year, only one-fortieth of the reserved jungle was assigned for woodcutters to cut trees on payment of a tax. Consequently, Sundarban reclamation was greatly decelerated by the end of the nineteenth century, although a certain number of development leases were granted later. ${ }^{15}$

The economic value of the Sundarbans was not limited to agricultural goods. In fact, huge profits were obtainable from the sale of forest products. For example, Sundri trees were indispensable for building country boats. Even by the 1870 s, country boats still carried by far the greatest share of commercial products in Bengal, although the railways steadily increased their mileage. Boat-building, therefore, constituted a very important sector in the traditional industries. By the 1870s, however, it had become increasingly difficult for boat-builders to obtain sufficient quantities of good Sundri timber. The overexploitation of the Sundarban forests was readily apparent and posed a severe threat to the industry. ${ }^{16}$

The importance of the Sundarban forests as a procurement base for firewood and an energy source for urban development during this period is indisputable. Woodcutters gathered smaller trees and shrubs and sent them by boat to Calcutta and other towns for sale as firewood. Until the midnineteenth century, woodcutters were free to collect firewood in the Sundarbans without paying any fee to the government. In 1891, however, Dansy, the Conservator of Forests, submitted a plan of imposing taxes on timber and firewood. He proposed that toll stations be established at three entrances to the Sundarban forests. Those wanting to cut trees were now compelled to obtain a lease beforehand and pay a tax at the toll stations according to the quantity of timber and firewood they actually cut. The lease of Sundari timber was nearly monopolized by merchants (mahajans) from the Bakarganj district, who supplied timber to the Dacca market and customers further north. ${ }^{17}$ 
Although reserved forests covered 1,758 square miles in the Sundarban area of the 24 Parganas district, because of the low quality and inadequate quantity of the firewood procurable there, they could not meet the growing demand of Calcutta and its suburban areas. The supply of fuel from the Khulna Sundarbans became critically important in sustaining the daily life of the metropolis. To collect and carry huge quantities of timber and firewood, innumerable boats used to flock to the Khulna Sundarbans. ${ }^{18}$ Between 1895 and 1904, the average annual collection of taxes on forest products amounted to Rs.450,000, which was nearly equivalent to the total land revenue collected from the entire Sundarban areas of the districts of Khulna and Bakarganj. ${ }^{19}$

As the demand for fuel vastly increased, wealthy peasants joined the ranks of woodcutters. They often rented out their agricultural lands to sharecroppers while working in the Sundarban forests. They hired boats, went to the forests, cut trees until their boats became full, and went to the upper regions of the river to sell them. Larger trees such as sundri, teak, and sal were used to build the country boats and houses, whereas smaller ones were used as fuel. Those who did not receive an advance from the trader often carried the timber to Chandkhali market in the Khulna district, the center of the wood trade. Traders of Calcutta who possessed big boats with a carrying capacity of 35-50 tons, for instance, sent them to the wood markets in Khulna to buy the firewood. ${ }^{20}$ Hunter estimated that more than 300,000 tons of wood were brought to Calcutta, of which 14,682 tons were carried by rail and 288,225 tons by boat. ${ }^{21}$

As explained above, the reclamation of the Sundarbans expanded rapidly from the 1830s till it reached its limit in the 1870s, when a considerable portion of the Sundarbans was designated as reserved forest. The Commissioner of the Sundarbans classified the total area of the Sundarbans (7,532.55 square miles) into three parts. ${ }^{22}$ The following figures give a general idea about the extent of reclamation in the $1870 \mathrm{~s} .^{23}$

1) Leased lands: $1,076,030$ acres (1681.29 square miles) or 22.3 percent of the total. Of these, 689,983 acres (1,078.09 square miles) or 14.3 percent had been reclaimed; 386,046 acres (603.19 square miles) or 8.0 percent lay uncultivated.

2) Reserved forests: $2,538,871$ acres (3,966.98 square miles) or 52.7 percent.

3) Area of navigable rivers and water courses: $1,205,942$ acres $(1,884.28$ square miles) or 25.0 percent.

\subsection{The process of reclamation in the Sundarbans}

Embankments were an essential component of reclamation work. Pure water running through the river was introduced into the fields by the construction of embankments, and they also protected the fields from saline 
water. Embankments needed to be repaired annually and at the correct time. Often, the marshes or basins (bils) were selected as reclamation sites. These bils were connected with the surrounding rivers and water courses (khals) by natural inlets through which water flowed. The first task for the reclaimer was to drain off the water. Traditional methods of draining the bils were well-established in the deltaic districts, where a vast tract of them existed. In forest clearings, farmers also had to contend with reeds. If cultivation was halted for a while, reeds proliferated once again, and the fields became unfit for cultivation.

It was usually considered the responsibility of the grantee of the Sundarban lease to clear the forest, to construct the water-control system at their cost, and to make the tract ready for cultivation. After these initial construction works were completed, it was left for him to decide whether he would manage the agriculture himself, or entrust it to others, usually local wealthy people called the haoladars.

When the initial stage of reclamation was completed, the organizer called in the cultivators to till the lands. The cultivators who started farming in the early years of reclamation, referred to as the abadkari raiyats, claimed that they had an occupancy right over their holdings. In the Jessore Sundarbans, they often lived in the old settled zone to the north and rented additional lands at a considerable distance ( 8 to 10 miles) from their residence, tending them by visiting from time to time. As the number of family members of these cultivators was not sufficient to maintain cultivation by themselves, they heavily depended on seasonal laborers (dawals), especially at harvest time. ${ }^{24}$ During the harvest season of December-February, many dawals flocked southward and cut the paddy on contract. ${ }^{25}$ Thus, the newly reclaimed southern region was often farmed by the resident cultivators of the northern region. The latter had been cleared earlier and the farming seasons were different there. Based on this time lag, there developed a peculiar type of agriculture as described above. Westland called these resident cultivators of the north, who used to resort to the south for cultivation, the double cultivators. When the paddy crop ripened, the grain traders started to visit the area and purchased paddy from the cultivators. The cultivators sold all the paddy and returned home with the proceeds. ${ }^{26}$ The Sundarbans therefore became a vital area for supplying food-grains for the increasing demands in Bengal, contributing to the development of commercial agriculture in the region as a whole. ${ }^{27}$

\subsection{The emerging agrarian society in the Sundarbans}

The emerging agrarian society in the Sundarbans was essentially a layered society similar to those that existed in older areas of rural settlement throughout Bengal. However, before exploring this aspect further, the major actors in the clearance process should be investigated first. 
The Sundarban Commissioner's office was set up at Alipur, a suburb of Calcutta, suggesting that people from Calcutta, including various European communities, landlords, professionals, merchants, East India Company employees, and government officers took the lion's share in the acquisition of the Sundarban leases. It is true that some of the grantees interested in reclamation had definite development plans, such as the Port Canning Development Project, the Sagar Island Project, and the Morrellganj Project. However, most were simply speculators without any intention of going into the remote jungle by themselves. They considered the lease a chance to make money. ${ }^{28}$

The rule of leases expected that the capitalists would reside on the spot and promote the reclamation by themselves. However, J. C. Jack wrote that, in the district of Bakarganj, '(many) of the grantees were European capitalists who found Bakarganj too distant a field for their attention, while the Bengali capitalists soon exhausted their capital.' He pointed out that among the grantees of leases, only two resided there and managed the reclamation operations themselves, and concluded that 'the capitalists were indeed only capitalists in name. ${ }^{29} \mathrm{He}$ further argued that the government failed to obtain the maximum potential land revenue from the Bakarganj Sundarbans because large-scale capitalists were given special priority in the grant of leases. According to him, at the beginning of the twentieth century, largescale capitalists retained eight grants (total area 11,528 acres, land-revenue Rs.8,215, and clearance percentage 55 percent), whereas small-scale capitalists possessed 383 grants (total area 23,614 acres, land-revenue Rs.67,106, and clearance percentage 86 percent). From the large-scale capitalist leases, the government realized only Rs. 0.7 per acre, while the revenue realized from the small-scale capitalist leases was four times as large (Rs.2.8 per acre). Consequently, from a revenue perspective, the large-scale capitalist system operated at a great loss.

Large-scale capitalists very often divided their leases into small sub-leases and sold them to the haoladars and other small-scale local capitalists, which only multiplied the subordinate intermediate tenure in the Sundarbans. Thus, a typical sub-infeudation process developed. Who, then, were the actual promoters of the reclamation on the site?

Westland's report gives us important information on this as well as the tenurial conditions in the Jessore Sundarbans ${ }^{30}$. The gist of his report is as follows. In the southern portion of Jessore, the Sundarban grants were mostly issued after the Permanent Settlement (1793), and the holders of these grants were called the Sundarban talukdars. They included 'several persons holding considerable zemindaris (estates)' in Jessore and nearby districts, but many others 'belong to the comfortably circumstanced class of people residing immediately north of the Sundarbans.' They accumulated 'just sufficient enough money... to carry on Sundarban reclamation with success' through land management and/or commerce. They directly managed the taluks themselves, and 'the greater part of the agricultural 
improvement and extension since the permanent settlement is owing (to them).' These talukdars paid 'rent for a village, or half of a village, sometimes cultivating [themselves], sometimes not.' They corresponded to the gantidar (rich peasant) of the older tracts. Thus, most of the talukdars in the Jessore Sundarbans originally belonged to 'the ryot series.' This stood in sharp contrast to other old localities outside the Sundarbans where the talukdars almost invariably belonged to 'the landholder series.' The Sundarban talukdars could, by the custom of the country, create subordinate tenure called haola within their own tenure, when direct management became too cumbersome. The haoladar had a right of occupancy and could also create several degrees of subordinate tenures called nim-haola, asathaola, and so on. The holders of the subordinate tenures almost always came from 'the pure ryot class.' Westland thought that ' $(t)$ hese tenures have their origin ... in rights founded upon original reclamation.'

Westland's report reveals that the majority of the talukdars originated from the cultivator's class, and that the talukdar and haoladars were the central figures in the promotion of the reclamation in the Jessore Sundarbans. Another record concerning the reclamation of the uninhabited islands in the deltaic areas of the Noakhali district clearly shows that clearance was promoted by the leadership, hard work and capital provided by the haoladars. ${ }^{31}$

Under the talukdars, haoladars, and subordinate haoladars, there were a large number of actual cultivators of the soil. They came to the newly reclaimed estates with the expectation of obtaining better conditions from the landlords. According to Westland,

[a] ryot who gets a small piece of land to clear always regarded as having a sort of property in it, an 'abadhkari swatwa' or 'reclamation right.' As reclamations extended, he begins to sub-let to other ryots. Then, we have a 'hawaldar' with his subordinate hawaladars in a few years.

Thus, a successful raiyat who settled in the newly reclaimed tract tended to transform himself into the haoladar before long.

Some poorer cultivators temporarily rented the lands from the raiyats or haoladars. They were called under-raiyats or charcha raiyats. Being placed outside the protection of the land law, their legal status was nothing more than tenants-at-will. Their names were not registered in the rent records. Often, they were obliged to pay very high rates of rent. About one-fifth of the cultivating class belonged to this category. When Jack wrote, '( $t$ )he cultivators of the Sundarbans were the most miserable of all the cultivators in the district, ${ }^{32}$ the cultivators he mentioned should be none other than this lowest class.

The emerging agrarian society in the Sundarbans was thus composed of four strata: grantees of the Sundarban lease (talukdar), organizers of reclamation and/or agricultural production (haoladar, nim-haoladar), cultivators (abadkari and ordinary raiyats), and under-raiyats (charcha raiyats). 
A similarly layered structure emerged in both the taluks of the European and Bengali capitalists. Hunter pointed out that, roughly speaking, everyone in the intermediate position of this layered structure secured one-fourth of what they received from below and paid the remaining part upward. ${ }^{33}$

This structure was noticed by William Dampier, the Commissioner in the Sundarbans, in his description of the Sundarban society as early as the 1830s. He wrote that in the Sundarbans the organizer of the reclamation received a grant (abadkari) from the zamindar, ${ }^{34}$ and was called the talukdar. This talukdar often created subordinate talukdars, and the subordinate talukdar created the haoladars, and so on. In the end, a highly complex sub-infeudation developed. Dampier remarked that in these chains, the true developers were the haoladars,

since they cleared the forest at their own expense and divided the lands when cleared amongst a lower class of men, nim-haoladars, who were at first genuine cultivators, but the improvement in the country and the rise in the value of land enabled them in turn to sublet their lands to karshas (ploughmen) who were merely labourers destitute of all rights.

He further added:

I have been much struck, whilst employed in this district by the general wretched condition of the lower orders. I was most particularly surprised, as I found the country itself was most fertile; and producing with but little tillage, all the necessaries in general use by the lower orders, whilst large markets are situated, in order to take off all the surplus produce; and a great trade in grain and betel-nut takes place between this district and Calcutta. Their condition could not therefore have arisen from the want of a vent for their produce, nor from the poverty of the soil not giving a sufficient return to their labour. It appears to me to have its source entirely in the conduct of the zamindars and intermediate landlords ${ }^{35}$

Juxtaposition of wealthy cultivators and miserably deprived poor people was already present. Thus, the highly stratified structure of the Sundarban agrarian society was already observed in the early years of the reclamation.

What, then, was the logic behind the emergence of the layered society in the Sundarbans? The Report of Rent Commission (1885) explains it as follows:

The grantee reclaimed portions, and sublet portions to smaller reclaiming tenants, or perhaps sublet the whole, if he could find tenants to reclaim it. These sub-lessees sublet again, and subletting was carried still lower, until the whole tract was divided into holdings of a manageable size for single families. The number of the grades doubtless varied with the size of the tract originally leased and with the denseness of the population in the particular locality ${ }^{36}$ 
Once the difficult initial stage of reclamation was completed, landlords, traders and money-lenders began to penetrate into the newly settled society. In consequence of deepening market relation, indebtedness spread among the cultivators, and some older settlers lost their land. In this way, the original society quickly transformed into a more complicated and stratified structure, at the bottom of which lived destitute cultivators and laborers without any surplus to improve production. ${ }^{37}$ When the extension of cultivation reached its limit in the late nineteenth century, this structure would work to prevent further agricultural growth in Bengal. This point will be further discussed in the conclusion.

\section{The market economy and agriculture in the Sundarbans}

\subsection{The rice trade}

By the late nineteenth century, the Sundarban districts had become the granary of Calcutta. They also supplied rice to rice-deficient districts such as Jessore (the northern part), Dacca, and Nadia. ${ }^{38}$ Some cultivators in the Sundarbans received advances from grain merchants who sent their servants to Sundarban villages in August/September to distribute money. In December/January and January/February, they sent their boats to collect paddy from the contracted cultivators. Small talukdars sometimes lent money to the cultivators as well. Repayment thereof was made in paddy. There were also cultivators who sold their produce directly at the weekly grain market (hat) or to itinerant traders (byaparis). Some others carried paddy by boat to the grain market located on the banks of the rivers.

The largest market was, of course, Calcutta. Rice produced in eastern Bengal was carried to Calcutta by country boats through the Sundarbans. One zamindar dug a canal connecting the Sundarban rivers with the Ganges and its tributary, which made it possible for boats to take an upward course. Another canal constructed in the late nineteenth century opened a shorter course to Calcutta. Boatmen preferred to take the northern route as much as possible, as larger boats that had to take a southern course passed through dense uninhabited jungles, where gangs of robbers frequently attacked the boats and created trouble. Experienced boatmen steered the boat cleverly by making use of changes in ebb and flow, and reached their destination in a shorter time. It took five days for a larger boat to go from Morrellganj to Chandkhali, the two largest markets in the Sundarbans.

\subsection{The Sundarbans in the wider market}

The reclamation of the Sundarbans expanded from the mid-nineteenth century in response to the increasing demand for its products. Until the Great Depression of 1929 this secular upward trend of demands basically 
continued. Although the driving force behind agricultural growth in Bengal was two world goods, indigo (from the end of the eighteenth century to 1860 ) and jute (from the early 1870 s to 1929), rice and paddy remained the mainstay of the internal market of Bengal throughout colonial rule. Rising market for rice came from swelling urban centers, especially Calcutta and its suburban industrial and commercial centers. The urban expansion was caused by inflow of industrial laborers from the United Provinces and Bihar, development of railway networks which increasingly connected Calcutta with distant markets, and the growth of the working population of Calcutta who were engaged in administrative, professional, commercial, financial, industrial and educational activities, and various services providing urban facilities and needs of daily life in Calcutta. Therefore, the need for rice and other agricultural and forest products such as betel nuts, pulses, vegetables, tobacco, date sugar, fuel, and timber continued to increase and their prices also rose.

The Sundarban districts were the largest supplier of rice to the Calcutta market and the predominant source of firewood, timber, and other forest products. Because the total sales of firewood and timber from the Sundarbans were said to be equal to those of rice, the profits accruing to the woodcutters, timber merchants, and boatmen who were engaged in these businesses must have been enormous.

To fully appreciate the economic prominence of the Sundarban districts their place in the overall structure of rice markets including Bengal, India, and neighboring countries should be explored. Rice exports from the Jessore district, even before the Sundarban reclamation gained momentum, had been considerable. In 1791, this district produced 900,000 mans ${ }^{39}$ (36,000 tons) of paddy, half of which was exported to Calcutta. From the Bakarganj district, rice amounting to 150,000 mans $(6,000$ tons) went to Calcutta by the river courses passing through the forests of Jessore. In 1794, the Company's government established a public granary system to prevent famine and scarcity in the capital. In so doing, they collected information related to rice availability in all major rice markets of Bengal. Among them, several Sundarban markets were listed.

Detailed information related to rice trade in 1876 (Report on the Internal Trade of Bengal for the Year 1876-77) allows us to examine the rice market structure of Bengal, and the significance of the Sundarban districts in it. The population of Calcutta, with its suburban centers, was about 900,000 in $1876 .{ }^{40}$ The annual consumption of rice by its inhabitants was estimated at about 4,100,000 mans, which is assumed to be the minimum requirement to be supplied to the Calcutta grain market. The Calcutta rice market was, in fact, much larger as it supplied rice to regions outside the Bengal presidency at the same time. For instance, by sea it exported rice amounting to $10,300,000$ mans in $1872,7,400,000$ mans in $1873,5,800,000$ mans in 1875, and 18,800,000 mans in 1876. In 1876, famines broke out in Bombay and Madras. Emergency dispatches 


\section{2}

Shinkichi Taniguchi

of rice had to be made: $8,500,000$ mans to Madras and 3,200,000 mans to Bombay. In addition to this export by sea, rice was sent to other divisions of the Bengal Presidency beyond Bengal proper. Rice was also exported to Nepal, Oudh, Assam, and North West provinces by land. In other words, the total demand-supply balance of rice in the Indian subcontinent was more or less maintained by rice exported from Bengal by railway, river, and marine transportation.

How was this gigantic export met? Table 3.2 shows that the total amount of rice that arrived in Calcutta in 1876 was $20,200,000$ mans, whereas total demand was $22,900,000$ mans $(18,800,000+4,100,000=$ $22,900,000)$. A shortage of $2,700,000$ mans was covered by a huge stock of rice amounting to $7,000,000$ to $8,000,000$ mans in the grain merchants' storehouses in and around Calcutta. No rice shortage occurred in the market in spite of the emergency exports to Madras and Bombay. In usual years, the total annual supply of rice to Calcutta was more than sufficient. Traders were able to acquire new rice and release older supplies so that the quality of their stocked rice would not deteriorate. Table 4.2 clearly shows how important the supply of rice from the Sundarban districts was for the entire supply and demand structure of rice in India.

By 1876, jute had established itself as the most important commercial good in Bengal agriculture. However, this did not diminish the significance of rice from the Sundarbans. The growth of jute cultivation in many districts of Bengal and rice cultivation in the Sundarbans were actually closely related. Jute cultivation could only expand rapidly because the supply of rice from the rice-producing districts in the Sundarbans could compensate for the fall in rice production in other jutegrowing districts. ${ }^{41}$

Table 4.2 Total Imports of Cleaned Rice to Calcutta (1876)

\begin{tabular}{lrr}
\hline Region & \multicolumn{1}{c}{ mans } & \multicolumn{1}{c}{$\%$} \\
\hline Sundarbans districts & $6,850,000$ & 33.9 \\
Western Bengal & $5,700,000$ & 28.2 \\
Central Bengal & $1,300,000$ & 6.4 \\
Northern Bengal & $1,100,000$ & 5.4 \\
Eastern Bengal other than Sundarbans districts & $2,300,000$ & 11.4 \\
Behar and Upper Provinces & 700,000 & 3.5 \\
Orissa & 400,000 & 2.0 \\
Assam & 100,000 & 0.5 \\
Unregistered & $1,750,000$ & 8.7 \\
Total & $20,200,000$ & 100.0 \\
\hline
\end{tabular}

Source: Report on the Internal Trade of Bengal for 1876-77. paras. 32-39. 


\section{Summary and conclusion}

The Sundarbans was the last and largest frontier in Bengal. Situated not far from Calcutta, the capital of the British Empire in India, its reclamation naturally attracted considerable attention from the government, European communities, and moneyed men in Calcutta. In the district of Bakarganj, only 21 grantees accounted for two thirds of the entire leased area, which strongly suggests that a handful of European and native colonial elites and other moneyed Calcutta residents secured a disproportionately large share of the Sundarban leases. However, very few of them entered the jungles and managed the reclamation work directly. Some had no interest at all in the development of its agriculture and obtained the leases only for speculation. Most grantees, be it Europeans or Bengalis, totally lost interest in land management and handed over the planning and promotion of cultivation of leased tracts under a special type of contract, called haola, to local promoters (haoladars). Most of the haoladars were rich peasants, but they also included some zamindars/talukdars or other intermediary tenure-holders from neighboring areas. Consequently, although the Calcutta connections dominated the top layer of the Sundarban tenure system, the traditional rural elites, of whom the rich peasants formed the majority, were integral to agricultural production in the Sundarbans.

The tenure of haola was heritable, transferable, sub-leasable, and divisible. The rent was fixed and the tenure continued as long as they paid rent regularly to the lease holders. The haoladars often cultivated land by themselves, but also brought in cultivators from neighboring districts by giving advance money and offering lower rates of rent. Some of these cultivators grew rich and became subordinate haoladars themselves, and created under-raiyats below them. These under-raiyats, locally called charcha raiyats, were legally mere tenants-at-will. Consequently, there emerged a layered society: grantee - haoldar/nim-haoladar - raiyat under-raiyat. The under-raiyats at the bottom of this layered society were described as miserable or very poor by experienced colonial administrators like Dampier and Jack, while the raiyats above them enjoyed prosperity. Westland opined that this layered structure was peculiar to the Sundarbans. However, I would argue that it was just a variant of the rich peasant-praja (subordinate people) relation that prevailed far and wide throughout Bengal. ${ }^{42}$

Sundarban reclamation was driven by the continual rise in agricultural prices and the burgeoning demand for rice and other forest products. As the population of Calcutta and its suburbs grew, so did their demand for rice, fuel, and timber. However, it did not stop there. The annual consumption of the food grain in the greater Calcutta area accounted for only 20-25 percent of the inflow of the rice into Calcutta grain markets in 1876 . Bengal rice was first sent to the Calcutta grain market, from thence it was re-exported by sea and land to Madras, Bombay and other markets. Some 
Bengal districts, which were perennially rice-deficient because of their poor soil and insufficient water supply, had to import rice from outside. The development of jute production at the cost of rice cultivation accelerated the rice trade between rice-sufficient regions and the rice-deficient one within Bengal. The overall result was the expansion of the rice trade throughout and beyond Bengal. Needless to say, the land reclamation and the agricultural development in the Sundarbans lay at the core of this expanding market.

Finally, implications of this chapter can be seen from a broader perspective. It is important to note that Bengal's land-frontiers had been almost exhausted by the end of the nineteenth century. In order to overcome this limitation, the region's agriculture needed qualitative development. More advanced method of agriculture such as diversification and multiple cropping, in other words, a vertical development of agriculture (enhancement of per acre productivity), became essential instead of a horizontal one (the mere extension of cultivation). Obviously, such a qualitative transformation of Bengal agriculture required a greater investment in agriculture. However, under the highly stratified agrarian structure that dominated Bengal agriculture, the necessary capital for agricultural improvement was difficult to find. ${ }^{43}$ Landlords had scarcely any interest in agricultural improvement, while haoladars were content with receiving high rates of rent from their subordinate haoladars and under-raiyats, and many other actual cultivators were destitute and without rights to the lands they cultivated. The result was that productivity of food-grains remained at a low average level, below one ton per hectare, at the time of independence (1947). This paltry figure shows that Bengal agriculture was lagging behind many other rice producing countries. At the root of this stagnation were the characteristics of the Bengal agrarian society, as has been discussed above. After the virtual disappearance of land-frontiers in Bengal, agricultural growth could not be sustained.

\section{Notes}

1 During preparation, the author strove to collect information from various sources such as contemporary works, government reports and Proceedings of the Government of Bengal (Revenue Department), as indicated in the references. It is yet regrettable that the most important source material that has been preserved in the district record rooms of the Collectorate offices of Bakarganj, Khulna and the 24 Parganas could not be consulted. The value of these records has been demonstrated prominently by Sirajul Islam in his outstanding work on intermediate land tenure: Islam (1988).

2 Table 4.1 and Figure 4.1 are arranged by divisions. Each division includes several districts. As of 1901, Bengal consisted of five divisions and two feudatory states, as shown below (Report on the Census of Bengal, 1901). Though two feudatory states were included in Bengal, they were omitted in the argument of the present paper. Also, see Map 4.1. 
Burdwan division: Burdwan, Birbhum, Bankura, Midnapore, Hoogly, Howrah

Presidency division: 24-Parganas (including Calcutta), Nadia, Murshidabad, Jessore, Khulna

Rajshahi division: Rajshahi, Dinajpur, Jalpaiguri, Darjeeling, Rangpur, Bogra, Pabna

Dacca division: Dacca, Mymensingh, Faridpur, Backergunge

Chittagong division: Tipperah, Noakhali, Chittagong, Chittagong Hill Tracts

Feudatory states: Kuch Bihar, Hill Tipperah

Strictly speaking, to obtain a precise picture of the demographic trend, many adjustments in accordance with boundary changes and creation and regrouping of the districts are in order. However, for our present argument, I merely regrouped the districts and did not adjust the divisional population to the boundary changes that often took place for the convenience of local administration. Data for the Calcutta municipality and its suburban areas are also given separately. Figure 4.1 shows the growth trend using 1881 as the base year. The figure indicates the following features: First, the fastest growth occurred in the divisions of Chittagong and Dacca, both of which belonged to eastern Bengal. Second, the slowest growth took place in the division of Burdwan. Third, the Presidency and Rajshahi divisions followed a more or less similar growth curve.

3 Islam (2012), Chs. 6 and 7.

4 Hunter (1875), p. 285.

5 Southern part of the Jessore district was separated, and formed into the Khulna district in 1882 .

6 Hunter (1875), p. 289.

7 Bengal District Gazetteers. 24-Parganas (1914), p. 178.

8 Bengal District Gazetteers. Khulna (1908), p. 41.

9 Jack (1915), p. 246.

10 Bengal District Gazetteers. 24-Parganas (1914), p. 182.

11 Bengal District Gazetteers. Khulna (1908), pp. 47-48.

12 Report on the Census of Bengal, 1881, Vol. I (1883), pp. 116-18.

13 Bengal District Gazetteers. 24-Parganas (1914), p. 185.

14 Bengal District Gazetteers. Khulna (1908), p. 84.

15 Ascoli (1921). Ch. VII of this book gives the details on the checkered history of the introduction of the reserved forests into Bengal.

16 Bengal District Gazetteers. Khulna (1908), p. 83.

17 Bengal District Gazetteers. Khulna (1908), p. 87.

18 Bengal District Gazetteers. Khulna (1908), p. 87.

19 Bengal District Gazetteers. Khulna (1908), p. 87. Hunter provided an interesting description of woodcutters and the wood trade of the Sundarban areas in the 1870s. Professional woodcutters usually lived in the northern part of the Sundarbans, went to the forests by boat, and stayed there for four months from the end of the rainy season. Many belonged to a woodcutter caste: the bhawali. They formed groups of 10-15 men, and sometimes received an advance from a wood trader. In return, they sent the timber to him. Other low-ranking castes such as pod, bagdi, koara, tior, chandala (namasudra), kaibartta, and kapali also engaged in this business. (Hunter, 1875: 304)

20 Hunter (1875), p. 310.

21 Hunter (1875), p. 311.

22 Hunter (1875), p. 285.

23 Hunter (1875), p. 336.

24 Westland (1874), Ch.42, pp. 1-19. 
25 They received their rewards in kind, usually one-eighth of the paddy they harvested.

26 However, such double cultivators seems to have been rather a peculiar type to Jessore. Usually, the cultivators settled in the newly reclaimed fields as we shall see later.

27 Westland (1874), Ch.42, pp. 1-19.

28 Hunter (1875), p. 344. Hunter wrote that out of 431 Sundarban leases in 1871, 19 leases were possessed by the Europeans. He also noted that most of the leaseholders did not reside in the Sundarbans.

29 Jack (1915), p. 268.

30 Westland (1874), Ch.42, pp. 75-78.

31 Proceedings of the Government of Bengal, Revenue Department. Branch-Land Revenue, August 1899, Nos.99-100 (Extracts from the rate reports of Char Bhadu, tauzi No.1666, in Noakhali,) pp. 677-723, para. 7. These records are concerned with reclamation of the government estates of Badu and Lukhi in the Sandwip Pargana of the Noakhali district adjacent to the Bakarganj Sundarbans.

32 Jack (1915), p. 268.

33 Hunter (1875), p. 338.

34 It seems that he spoke of reclamation in the zamindars' estates.

35 Jack (1915), p. 253.

36 Quoted from Proceedings of the Government of Bengal, Revenue Department. Branch-Land Revenue, August 1899, Nos. 99-100, pp. 677-723 (Extracts from the rate reports of Char Bhadu, tauzi No.1666, in Noakhali, p. 14).

37 Jack (1915), p. 214.

38 Taniguchi (2008).

39 Man is a unit of weight. 1 man equals slightly less than 40 kilograms.

40 This figure is about 30 percent larger than that reported in the Census of 1881. Perhaps coverage of Calcutta in this report differed from that of the census. See Table 4.1.

41 I did not take up the new development in the international rice market as a result of the emergence of rice exports from Burma (Myanmar), Siam (Thailand), etc. in this chapter. See Report of the Bengal Paddy and Rice Enquiry Committee, Vol. 1, 1940.

42 For more about peasantry, please refer to Taniguchi (2017).

43 In this connection, the role of the government in the development of modern agriculture needs to be studied. A comparative study with the Japanese case may be fruitful.

\section{References}

Ascoli, F. D. (1921). A Revenue History of the Sundarbans from 1870 to 1920, Calcutta: The Bengal Secretariat Book Depot.

Bourdillon, J. A. (1883). Report on the Census of Bengal, 1881, Vol. I., Calcutta: The Bengal Secretariat Press.

Government of Bengal. (1877). Report on the Internal Trade of Bengal for 1876-77, Calcutta: Government of Bengal.

Government of Bengal. (1899). Proceedings of the Government of Bengal, Revenue Department. Branch-Land Revenue, August, Calcutta: Government of Bengal.

Government of Bengal. (1940). Report of the Bengal Paddy and Rice Enquiry Committee, Vol. I, Alipur, Bengal: Department of Agriculture and Industries.

Government of India. (1881-1931). Census of Bengal, Calcutta: Decennial Publications. 
Hunter, W. W. (1875). A Statistical Account of Bengal, Volume I. Districts of the 24 Parganas and Sundarbans, London: Trubner \& Co. (reprinted in 1973).

Islam, M. M. (2012). An Economic History of Bengal, 1757-1947, Dhaka: Adorn Publication.

Islam, S. (1988). Bengal Land Tenure. The Origin and Growth of Intermediate Interests in the 19th Century, Calcutta: K. P. Bagchi \& Company.

Jack, J. C. (1915). Final Report on the Survey and Settlement Operations in the Bakarganj District, 1900 to 1908, Calcutta: Bengal Secretariat Book Depot.

Jack, J. C. (1918). Bengal District Gazetteers. Bakarganj, Calcutta: Bengal Secretariat Book Depot.

Lahiri, R. S. A. C. (1936). Final Report on the Survey and Settlement Operations in the District of 24-Parganas for the Period 1924-1933, Calcutta: Bengal Government Press.

O’Malley, L. S. S. (1908). Bengal District Gazetteers. Khulna, Calcutta: Bengal Secretariat Book Depot.

O’Malley, L. S. S. (1912). Bengal District Gazetteers. Jessore, Calcutta: Bengal Secretariat Book Depot.

O’Malley, L. S. S. (1914). Bengal District Gazetteers. 24-Parganas, Calcutta: Bengal Secretariat Book Depot.

Pargiter, F. E. (1885). Revenue History of the Sundarbans from 1765 to 1870, Alipur. (1934 (reprint)), Calcutta: Bengal Secretariat Book Depot.

Rennell, J. (1781). The Bengal Atlas of James Rennell's, reprinted in James Rennell's Memoir of A Map of Hindostan or the Mughal Empire and His Bengal Atlas, edited by B. P. Ambashthya, Patna: N. V. Publications (n.d.).

Sen, R. S. (1874). Report of the Agricultural Statistics of Jhenidah, Magurah, Bagirhat, and Sunderbuns Sub-Divisions, District Jessore, 1872-73, Calcutta: Bengal Secretariat Press.

Taniguchi, S. (2008). "Trade, Market, Production and Consumption Structures in Late Colonial Bengal as Revealed from the Report on the Internal Trade of Bengal for 1876-77," Discussion Papers No. 2008-1, Tokyo: Graduate School of Economics, Hitotsubashi University. (in Japanese).

Taniguchi, S. (2017). "Rethinking the Bengal Peasantry in History," In Chakrabarti, S. and U. Patnaik eds., Agrarian and Other Histories Essay for Binay Bhushan Chaudhuri, New Delhi: Tulika Books, pp. 41-64.

Westland, J. (1874). A Report on the District of Jessore: Its Antiquities, Its History, and Its Commerce, Second Edition (Revised and Corrected), Calcutta: Bengal Secretariat Press. 


\title{
5 Sustaining tank irrigation in south India through time-tested measures*
}

\author{
Kuppannan Palanisami \\ EMERITUS SCIENTIST, INTERNATIONAL WATER MANAGEMENT INSTITUTE, NEW DELHI
}

Mohanasundari Thangavel

ASSISTANT PROFESSOR, DEPARTMENT OF AGRICULTURAL ECONOMICS, PGP COLLEGE OF AGRICULTURAL SCIENCES, NAMAKKAL, TAMIL NADU

\section{Introduction}

Tank irrigation has existed in India since Vedic times. Numerous tanks feature inscriptions that can be dated back a millennium or longer, providing evidence that tank-based rain collection is deeply rooted in south Indian irrigation culture. These containers were developed for several purposes, including domestic use, irrigation, pisciculture, recreation, and livestock water. Semi-arid regions of India have approximately 120,000 small-scale tanks, supplying water for about 4.12 million ha. The largest concentration of irrigation tanks is found in the three southern states of Andhra Pradesh, Karnataka, and Tamil Nadu, which collectively account for nearly 60 percent of India's tank-irrigated area. Today, the tanks are not performing well and are regarded as neglected opportunities. Groundwater development has improved overall tank performance in several locations but large gaps persist. Using Tamil Nadu as a case study, this chapter briefly outlines the history of this water collection system, explains the dynamics of tank-well interaction and suggests possibilities for reviving tank ecosystems as a rural livelihood enhancement strategy.

\section{The distribution of tanks}

Tanks were created as the best system for harvesting rainwater, therefore the distribution of tanks mirrors rainfall patterns (in terms of intensity and quantum). Tamil Nadu has about 38,949 tanks of varying sizes and scales across the state, including panchayat union (PU) tanks with a command (irrigated) area of less than 40 ha and public works department (PWD) tanks with a command area of more than 40 ha. About 78 percent of all tanks are of the PU category. Tanks are classified as either system tanks (filled partially from rivers/reservoirs) or non-system tanks (purely rainfall dependent). About 88 percent of all tanks are non-system tanks. 
Consequently, small rainfed tanks represent the typical tank irrigation in the state. Rainfall $(800-1,100 \mathrm{~mm}$ ), terrain (land slope 3-7 percent) and soil type (mostly clay, clay loam) collectively indicate the geographical distribution of tanks (Table 5.1, Map 5.1).

Table 5.1 Distribution of Tanks and Rainfall in Tamil Nadu, India

\begin{tabular}{llll}
\hline & Tanks (no.) & $\begin{array}{l}\text { Tank irrigated } \\
\text { area (ha) }\end{array}$ & $\begin{array}{l}\text { Rainfall } \\
\text { (mm/annum) }\end{array}$ \\
\hline $\begin{array}{l}\text { Tank-intensive regions: (north and } \\
\text { south) }\end{array}$ & 30,971 & 579,465 & $800-1,100$ \\
$\begin{array}{l}\text { Less tank-intensive regions: (central) } \\
\text { Total }\end{array}$ & 7,978 & 50,801 & $600-800$ \\
& 38,949 & 630,266 & 925 \\
\hline
\end{tabular}

Source: Government of Tamil Nadu (2012a).

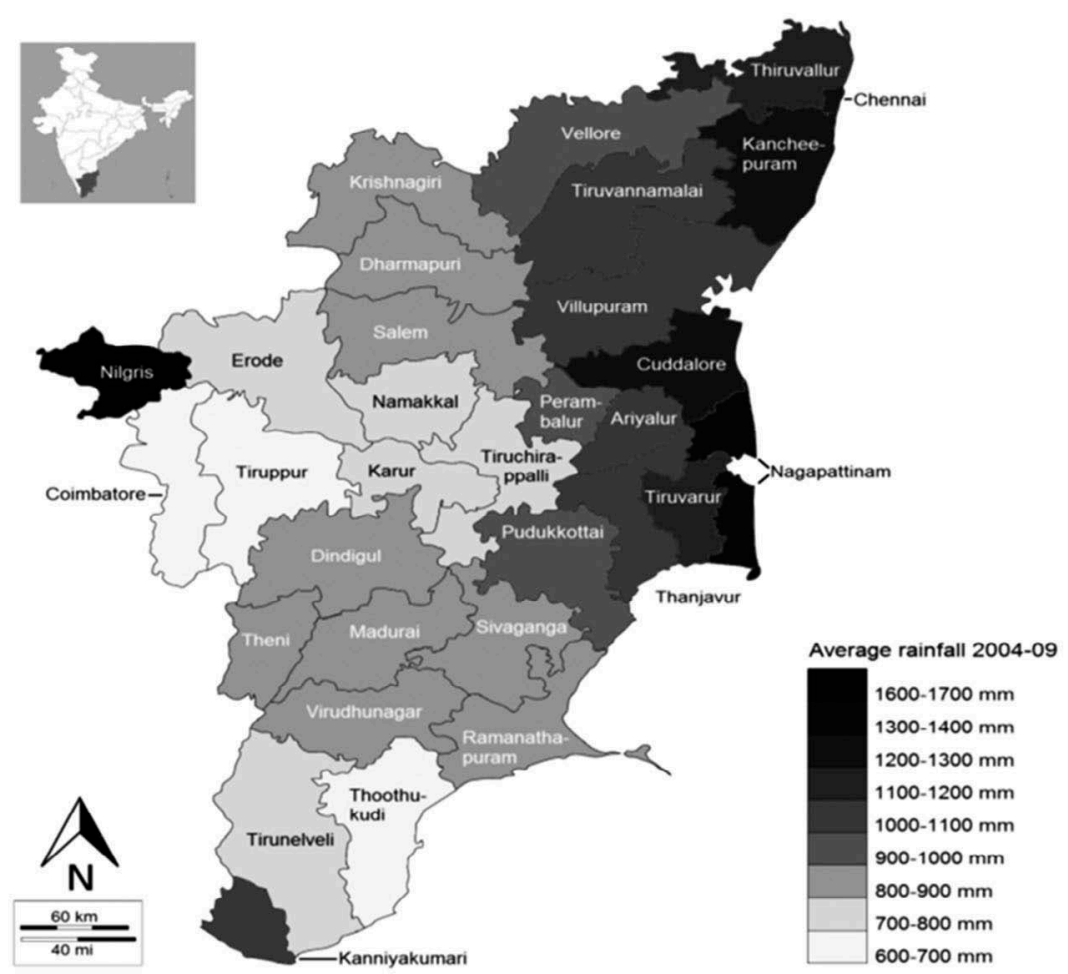

Map 5.1 Rainfall Distribution in Tamil Nadu 


\section{K. Palanisami and M. Thangavel}

\section{Declining tank performance}

Since the 1980s, tank performance has been declining. The tank-irrigated area has declined from 0.9 million ha in the 1970s to 0.77 million ha in the 1980s, 0.63 million ha in the 1990s, and 0.42 million ha in the 2000s, with the compound growth rate varying from +1.58 percent/year during 1985-95 to -2.36 percent/year during $2005-13$. The tank filling pattern indicates that a greater number of deficit tank filling years has led to a decline in reliance upon this mode of water supply (Tables 5.2 and 5.3). Rainfall variation, siltation, encroachment, lack of tank institutions, and poor management has caused poor tank performance. Groundwater supplementation by farmers increased prior to the 1990s to meet this deficit, supplying their own fields as well as their neighbors' (a localized water market). However, this development fell stagnant by 2000 and has been almost non-existent in recent years.

A rough calculation based on in-depth studies and discussions with different stakeholders indicates that tanks have lost 30-35 percent of their water storage capacity. Groundwater initiatives to date have helped to manage about $8-10$ percent of the tank storage loss. Bridging the remaining gap is apparently a difficult task. It is argued that proper tank management and aquifer development in the tank command will help to improve the overall supplies from both tanks and wells.

Table 5.2 Rainfall and Tank Storage, Tamil Nadu

\begin{tabular}{lll}
\hline Average wet-season rainfall $(\mathrm{mm})$ & State of tank storage & Probability of occurrence \\
\hline$>500$ & Surplus & 0.10 \\
$450-500$ & Normal & 0.20 \\
$300-450$ & Deficit & 0.50 \\
$<300$ & Failure & 0.20 \\
\hline
\end{tabular}

Note: Based on 46 years of rainfall data (Palanisami et al., 2011a).

Table 5.3 Trend in Tank-Irrigated Area, Tamil Nadu (\%)

\begin{tabular}{lcccccc}
\hline Source & $1960-61$ & $1970-71$ & $1980-81$ & $1990-91$ & $2000-01$ & $2010-11$ \\
\hline Canals & 35.8 & 32.5 & 32.7 & 31.5 & 27.5 & 24.7 \\
Tanks & 38.0 & 33.1 & 21.7 & 21.7 & 19.5 & 17.6 \\
Wells & 24.2 & 33.2 & 44.8 & 46.3 & 52.5 & 57.5 \\
Others & 2.0 & 1.3 & 0.9 & 0.5 & 0.5 & 0.3 \\
All & 100.0 & 100.0 & 100.00 & 100.0 & 100.00 & 100.0 \\
\hline
\end{tabular}

Source: Government of Tamil Nadu (2012a). 


\section{The dynamics of a tank-aquifer agro-ecosystem}

Farmers normally transplant rice immediately after the start of the first tank filling (September-October).The risk associated with getting adequate water, especially late in the season, has encouraged farmers to use wells for supplemental irrigation, particularly later in the crop season (DecemberJanuary).Results of studies have shown high returns from supplemental irrigation and the stabilization of the value of groundwater in the tanks (Palanisami et al., 2011a). As wells recharge directly from the tanks through horizontal percolation, the hydraulic relation between tanks and wells has been well-established over the years.

Figure 5.1 depicts the interaction between tanks and wells in normal and deficit rainfall years. Groundwater augmentation is not proportional to tank water deficits in deficit and failure years. The groundwater supply is much less when the tank storage falls below 30 percent. This raises important questions: Why do tanks not provide a platform for well investment? Why have more wells notbeen initiated? The figure shows that the well density is less $(0.46 /$ ha of net sown area [NSA]) in tank regions than in non-tank, mostly well-irrigated, central regions ( 1 well/ha of NSA) (Table 5.4). Among the tank-intensive districts, the number

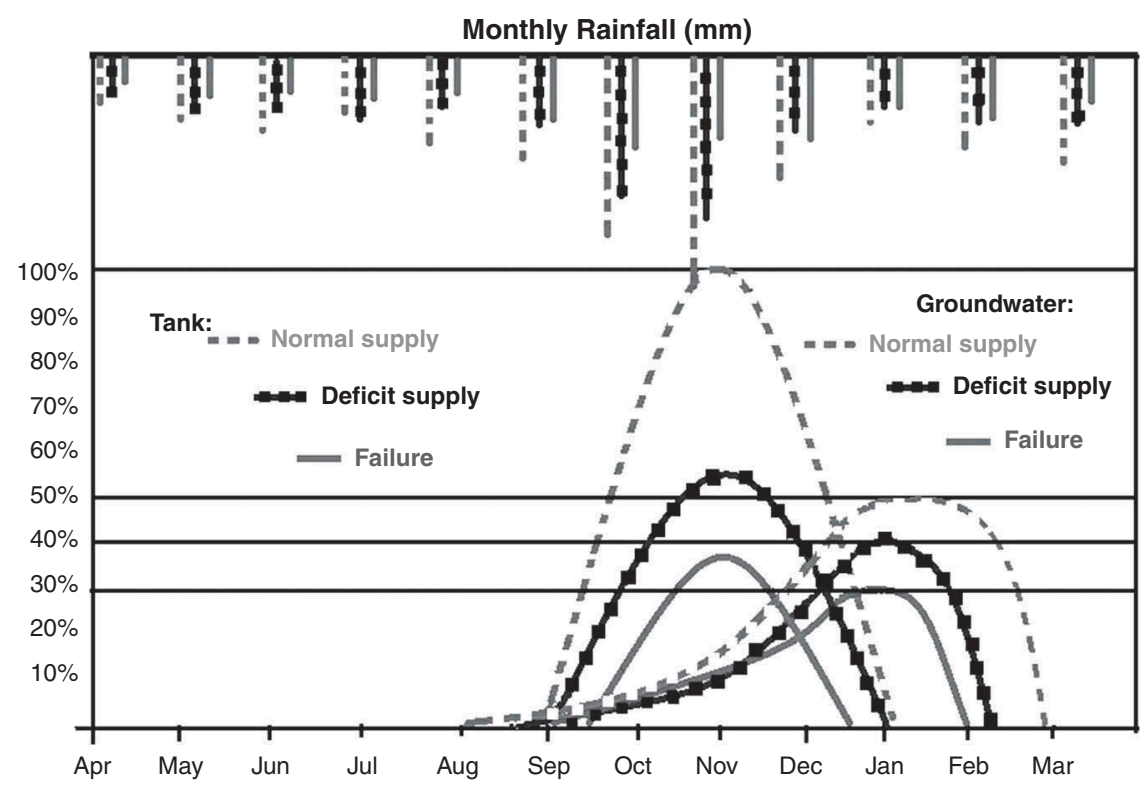

Figure 5.1 Behavioral Relation between Tanks and Wells in Different Tank Filling Years

Source: Author's estimation. 
Table 5.4 Groundwater-tank Ecosystem Interface

\begin{tabular}{|c|c|c|c|c|c|}
\hline No. & Particulars & & 1985-95 & $1995-2005$ & $2005-13$ \\
\hline \multirow[t]{4}{*}{1} & \multirow[t]{4}{*}{$\begin{array}{l}\text { Water supply } \\
\text { level }(\%)\end{array}$} & $\begin{array}{l}\text { Tank water } \\
\text { supply }(\%)\end{array}$ & \multicolumn{3}{|c|}{ Groundwater supply (\%) } \\
\hline & & $\begin{array}{l}\text { Normal year } \\
80-100\end{array}$ & $5(5)$ & $20(20)$ & $30(30)$ \\
\hline & & $\begin{array}{l}\text { Deficit year } \\
50-80\end{array}$ & $20(30)$ & $40(50)$ & $20(60)$ \\
\hline & & $\begin{array}{l}\text { Failure year } \\
<50\end{array}$ & $20(40)$ & $20(60)$ & $10(70)$ \\
\hline \multirow[t]{6}{*}{2} & \multirow{6}{*}{$\begin{array}{l}\text { Groundwater } \\
\text { supplementation } \\
(\%)\end{array}$} & For own fields & 100 & 90 & 70 \\
\hline & & North region & 100 & 100 & 80 \\
\hline & & South region & 100 & 80 & 60 \\
\hline & & $\begin{array}{l}\text { For water } \\
\text { market }\end{array}$ & 80 & 60 & 10 \\
\hline & & North region & 80 & 70 & 15 \\
\hline & & South region & 80 & 50 & 5 \\
\hline \multirow[t]{2}{*}{3} & \multirow{2}{*}{$\begin{array}{l}\text { Well density } \\
\text { (no. wells/ha) }\end{array}$} & North region & 0.42 & 0.54 & 0.60 \\
\hline & & South region & 0.23 & 0.25 & 0.26 \\
\hline \multirow[t]{2}{*}{4} & \multirow{2}{*}{$\begin{array}{l}\text { Non-functioning } \\
\text { wells }(\%)\end{array}$} & North region & 0 & 10 & 15 \\
\hline & & South region & 0 & 5 & 10 \\
\hline
\end{tabular}

Note: figures in brackets represent groundwater demand in terms of compound growth rate. Source: derived from the current field survey and also from past studies.

of tanks, number of wells, and the size of the well and tank irrigated area showed marked variation between the northern and southern regions of the state. The well density in the northern region is almost double that of the southern region. This may be because of rainfall patterns in southern regionsthat benefit more from southwest monsoons (June-September) than from northeast monsoons (October-December) and the diverse soil types and cropping patterns that support the growth of wells. Over the years, well failure has also increased in the tank regions, indicating recharge problems caused by poor tank storage management. It appears that tank supplies are exhausted within 2 months of the start of tank season compared to the 3-4 months recorded during the 1980s and 1990s. Therefore, tank storage management options must be examined along with the potential number of wells that can be dug in the tank commands.

\section{The current status of groundwater development and future potential}

Data show that wells in tank-intensive regions account for about 48 percent of existing wells in the state. Among tank-intensive regions, the northern region accounts for more wells ( 69 percent) than the southern region ( 31 percent). 
Table 5.5 Existing and Feasible Numbers of Wells in Tank Commands

\begin{tabular}{|c|c|c|c|c|c|c|c|}
\hline & $\begin{array}{l}\text { Existing no. } \\
\text { of wells }\end{array}$ & $\begin{array}{l}\text { Feasible no. } \\
\text { of wells }\end{array}$ & $\begin{array}{l}\text { Total no. } \\
\text { of wells }\end{array}$ & $\begin{array}{l}\% \text { to } \\
\text { total }\end{array}$ & $\begin{array}{l}\text { Tank } \\
N S A(h a)\end{array}$ & $\begin{array}{l}\text { Ratio of } \\
\text { existing } \\
\text { wells to } \\
\text { NSA }\end{array}$ & $\begin{array}{l}\text { Ratio of } \\
\text { total wells } \\
\text { to NSA }\end{array}$ \\
\hline $\begin{array}{l}\text { Tamil } \\
\text { Nadu } \\
\text { state }\end{array}$ & $1,836,055$ & 220,602 & $2,056,657$ & & $4,544,240$ & 0.40 & 0.45 \\
\hline $\begin{array}{l}\text { Tank } \\
\text { district: }\end{array}$ & 889,440 & 189,684 & $1,079,124$ & 52 & $2,109,260$ & 0.42 & 0.51 \\
\hline a) North & 613,695 & 52,502 & 666,197 & 62 & $1,039,103$ & 0.59 & 0.64 \\
\hline b)South & 275,745 & 1371,82 & 412,927 & 38 & $1,070,157$ & 0.26 & 0.39 \\
\hline
\end{tabular}

Note: Total no. of wells refers to the no. of existing and no. of feasible wells. NSA=net sown area.

Estimates of the feasible number of wells (worked out using the annual groundwater draft available for development) show that about 220,602 wells could be possible, accounting for 12 percent of the existing level in the state and 21 percent of the wells in the tank regions (Table 5.5). Among the tank regions, the southern region has more potential for this future well expansion (50 percent) than the northern region (9 percent) because the northern region has already exploited 91 percent of its groundwater potential.The tanks in this region have about 1 well for every 2 ha of NSA. The southern region has about 1 well for every 4 ha of NSA,which is expected to become 1 well for every 3 ha of NSA when all feasible wells are included.

\section{Determinants of well investment in tanks}

Past studies and the present status of the tanks demonstrate that tank irrigation can survive in the future provided that well irrigation is ensured through adequate groundwater development. Therefore, it is important to assess the scope for well development and the specific potential constraints that could occur when expanding well irrigation in the tank commands. Based on the literature and focus-group discussions in the tank districts, one can infer that the rainfall pattern, tank performance, soil type, and aquifer characteristics influence well investment in tank commands. The following sections particularly address these points.

\subsection{Rainfall patterns}

The variation in rainfall patterns was $29-37$ percent in the northern region and 36 percent in the southern region, which in turn has influenced the tank-irrigated area over the years (Table 5.6). It is noteworthy that the rainfall deviation has reflected in tank-irrigated areas, resulting in higher well 
Table 5.6 Rainfall Variation in the Tank Regions

\begin{tabular}{llrr}
\hline & & North & South \\
\hline & SW normal & 452.5 & 205.42 \\
& SW actual & 321.2 & 132.3 \\
& SW CV (\%) & 29.1 & 35.6 \\
& NE normal & 556.5 & 438.2 \\
Rainfall (mm) & NE actual & 348.6 & 282.3 \\
& NE CV (\%) & 37.4 & 35.5 \\
& Annual normal & $1,009.0$ & 643.6 \\
& Annual actual & 669.8 & 414.6 \\
& Annual CV (\%) & 33.6 & 35.6 \\
\hline
\end{tabular}

SW: southwest monsoon; NE: northeast monsoon; CV: coefficient of variation.

Table 5.7 Change in Rainfall and Change in Well Density and Area Irrigated

\begin{tabular}{lllll}
\hline Year & Region & $\begin{array}{l}\text { Deviation in } \\
\text { Rainfall }\end{array}$ & $\begin{array}{l}\text { Well density } \\
\text { (no of wells/ha) }\end{array}$ & $\begin{array}{l}\text { Deviation in Tank } \\
\text { irrigated area }\end{array}$ \\
\hline \multirow{2}{*}{ 1996-97 } & South & 0.12 & 0.46 & -0.41 \\
& North & -0.03 & 0.63 & -0.29 \\
$2000-01$ & South & 0.06 & 0.41 & -0.46 \\
& North & -0.36 & 0.71 & -0.48 \\
$2004-05$ & South & 0.45 & 0.38 & -0.51 \\
& North & -0.14 & 0.71 & -0.62 \\
$2008-09$ & South & 0.25 & 0.33 & -0.46 \\
& North & 0.00 & 0.67 & -0.68 \\
$2012-13$ & South & 0.02 & 0.42 & -0.58 \\
& North & -0.14 & 0.80 & -0.63 \\
\hline
\end{tabular}

density in the northern region than inthe southern region (Table 5.7, Figures 5.2 and 5.3).

\subsection{Soil type}

Clay loam soils are more common in northern districts (6 percent) than in southern ones (1 percent). However, loamy sand is more frequently found in the south (18 percent) than in the north (8 percent). Sandy loam occurs more (32 percent) in the north than in the south (19 percent) (Table 5.8). The soil characteristics more or less confirm that soils in the northern districts have more water infiltration and that the groundwater quality is also 


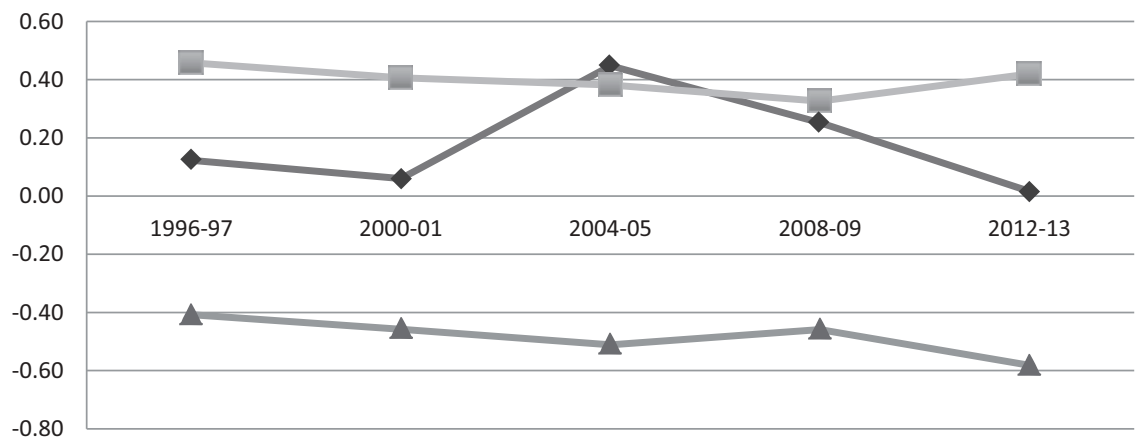

$\bullet$ Deviation in Rainfall $\quad-$ Well density $\quad \longrightarrow$ Deviation in Tank irrigated area

Figure 5.2 Well Density, RF Deviation with Tank area Deviation_South

Source: Author's estimation

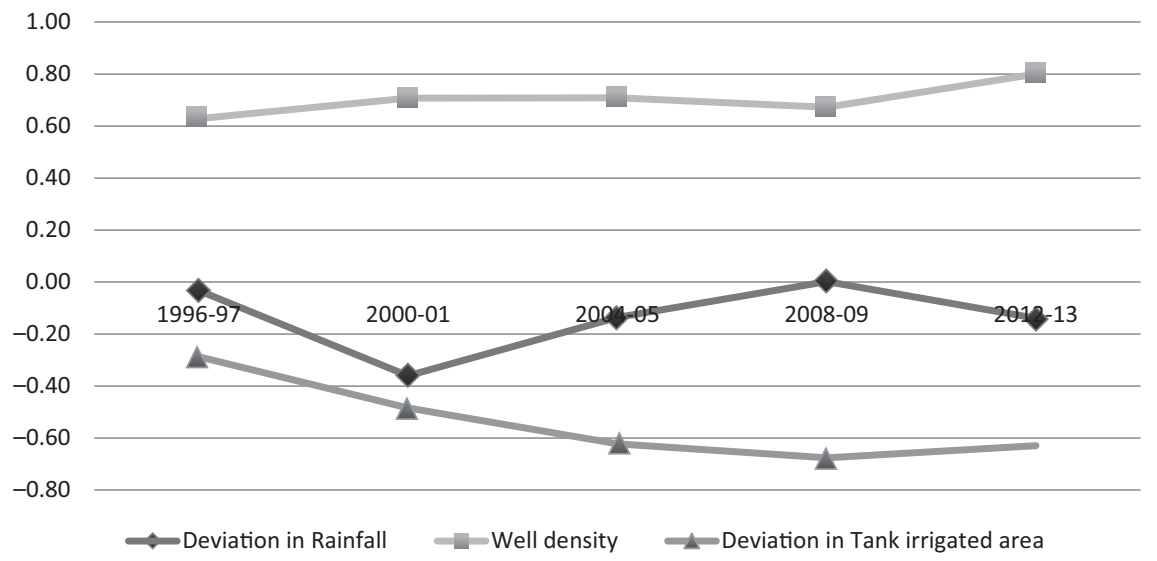

Figure 5.3 Well Density, RF Deviation with Tank area Deviation_North Source: Author's estimation

good. Therefore, farmers might be inclined to use more groundwater even after the tank water is exhausted. In the case of the south, more saline water is observed in the wells when pumped from deep aquifers.

Soil types are also embedded in some tank descriptions. For example, two tank-bed areas have been referred to respectively as mankalanadu and karisalkadu. The term mankalanadu derives from manal man (sandy porous soil).The opposite cultural ecological category karisalkadu comes from karisal man(water retentive heavy clay soil). The upper reaches of the Sarugani 
Table 5.8 Distribution of Soil Types in the Tank Regions (\%)

\begin{tabular}{lcc}
\hline Soil Type & North & South \\
\hline Clay & 15 & 17 \\
Clay loam & 6 & 1 \\
Loam & 0 & 0 \\
Loamy sand & 8 & 18 \\
Sand & 4 & 9 \\
Sandy clay & 15 & 20 \\
Sandy clay loam & 20 & 16 \\
Sandy loam & 32 & 19 \\
Silty clay & 2 & 0 \\
\hline
\end{tabular}

Source: Soil survey records from the selected tank districts.

minor basin are dominated by light sandy soil (mankalanadu). Heavy clay soil (karisalkadu), on the other hand, predominates in the lower reaches. In the upper sandy soil areas, bunds (earthen walls with wide bases and 3 to 5 meters high) are weaker; the tanks tend to be smaller. In the clay soil areas, where there is less risk of breaching, bunds tend to be longer; the tanks are more elongated. In the upper part of the catchment(mankalanadu), lateritic red soils produce high run-off and densely packed tanks are interspersed with uncultivable land. In the cultivable tracts, the wetland of one tank abuts the foreshore of the next, producing a close patchwork of cultivated land and tanks that are almost equal in area. On these sandy porous soils, rice is mainly transplanted. Groundwater is saline. Only isolated pockets of land are irrigable by wells. Actually, cultivation depends almost entirely on tank irrigation. Most dry land is uncultivable waste. Therefore, the land between the tanks is not encroached upon much.

In the lower southeastern area (karisalkadu), more widely spaced tanks on water-retentive clay soils irrigate a smaller proportion of agricultural land and are separated by large tracts of dryland on which rice, chili peppers, cotton, linseed, coriander, vegetables and a wide variety of other crops are grown. Overall, tanks have a less critical role in the karisalkadu farming system, in which rainfed cultivation plays a far greater part and a more mixed cropping pattern is allowed. On water-retentive soils, all crops demand less frequent irrigation than in mankalanadu villages. A lesswaterintensive direct-sown rice has long dominated irrigated and drylands in karisalkadu. Even in years of scant rainfall, some grain will be harvested, particularly millets. Overall, the benefits of tank irrigation (increased profit and reduced risk) are less in black soil than in red-soil areas. Moreover, the difference between wet and dry land prices, a good indicator of long-run productivity, yield, and risks of land, is smaller in the black soil areas than 
in the red soil areas. That is true because of the possibility for rainfed cultivation. The encroachments between the tanks are higher in black soil areas (Mosse, 1996).

\subsection{Aquifer characteristics}

Aquifer characteristics also reflect that northern districts favor groundwater development more than in the south; the northern districts have aquifers that are more likely to have hard rock, sandy clay, and alluvium than the mostly hard rock nature of aquifers in the south. Transmissivity and permeability are also more favorable in northern districts than southern districts (Table 5.9).

In addition to the determinants of well investment presented above, an in-depth survey was undertaken in different tank cascades both in northern and southern regions. Based on these observations, the following determinants have been identified.

\subsection{Tank location and type (PU vs. PWD) in the tank cascade}

This chapter reports the results of an earlier study conducted to examine the distribution of wells according to tank types and their location characteristics (Palanisami, 2000; Palanisami \& Easter, 2000). Of all 80 tanks studied, 51 were PU tanks, whereas 29 were PWD tanks. Of all PU tanks, 55 percent of the tanks were in head reaches, whereas 45 percent of the tanks were in tail reaches.Among PWD tanks, 58.6 percent of tanks were in the tail reach; 41.4 percent of tanks were in the head reach. Therefore, one might conclude that a higher proportion of tanks in the head reach were PU tanks and that a higher proportion of tanks in the tail reach were PWD tanks. However, an analysis of the size distribution of tanks among PU and PWD tank groups across head and tail reaches revealed that PWD tanks in head reaches were larger than the PWD tanks in the tail reaches. About 16.7 percent of PWD tanks in head reaches had more than 200 ha of

Table 5.9 Type of Aquifer in the Tank Regions

\begin{tabular}{lllll}
\hline District & Aquifer Type & Well yield & Transmissivity $(T)$ & Permeability $(K)$ \\
\cline { 3 - 5 } & & $($ lpm $)$ & $\left(m^{2} /\right.$ day $)$ & $($ m/day $)$ \\
\hline \multirow{2}{*}{ North } & Hard rock & $40-220$ & $10-80$ & $0.5-2.56$ \\
& Sandy-clay & $46-68$ & $23-52$ & $0.5-3.0$ \\
& Alluvium & $150-400$ & $200-300$ & $20-30$ \\
\multirow{2}{*}{ South } & Hard rock & $40-110$ & $0.224-0.640$ & $0.049-0.147$ \\
\hline
\end{tabular}

Note: North denotes Kancheepuram; south denotes Virudhunagar. 
command area, although no PWD tank in the tail reach of the chain had more than 200 ha of command area. However, among PU tanks in head reaches, 86 percent of the tanks had a command area of less than 20 ha, whereas, among the PU tanks in tail reaches, more than 60 percent had a command area of 20-40 ha. These data imply that the variation in command area is higher in head reaches of the chain than in the tail reaches. Overall tank type and size and tank characteristics play a major role in well distribution in the tank command area (Tables 5.10 and 5.11).

The free catchment per hectare of the command was about 1.75-2 times higher in PU tanks than in PWD tanks, both in the head and tail reaches, indicating that the location of tanks in the chain is a more important factor in influencing tank storage. Similarly, the combined catchment per hectare of the command area was about 2.5-3.5 times higher in PU tanks than in PWD tanks in the head and tail reaches of the chain. However, the ratio of free to combined catchment was almost equal for both PU and PWD tanks in both the head and tail reaches. Although the free catchment was about

Table 5.10 Distribution of PU Tanks in the Tank Cascade based on Command Area

\begin{tabular}{lllllll}
\hline Reach & \multicolumn{3}{l}{ Tank command area $(\mathrm{ha})$} & \multirow{2}{*}{$\begin{array}{l}\text { Mean command } \\
\text { area and well density }\end{array}$} \\
\cline { 2 - 5 } & $<10$ & $10-20$ & $20-30$ & $30-40$ & \\
\hline $\begin{array}{l}\text { Head } \\
\text { (no. of tanks) }\end{array}$ & 12 & 12 & 3 & 1 & $13.02 \mathrm{ha}$ \\
$\begin{array}{l}\text { Well density (no. wells/ha) } \\
\text { Tail (no. of tanks) }\end{array}$ & 0.54 & 0.65 & 0.68 & 0.63 & 0.63 \\
Well density (no. of wells/ha) & 0.56 & 0.66 & 0.67 & 0.69 & $\begin{array}{l}20.76 \mathrm{ha} \\
0.65\end{array}$ \\
\hline
\end{tabular}

Source: Prepared by authors based on Palanisami (2000); Palanisami \& Easter (2000).

Table 5.11 Distribution of PWD Tanks in the Tank Cascade based on Command Area

\begin{tabular}{|c|c|c|c|c|c|c|}
\hline \multirow[t]{2}{*}{ Reach } & \multicolumn{5}{|c|}{ Tank command area (ha) } & \multirow{2}{*}{$\begin{array}{l}\text { Mean command } \\
\text { area and well } \\
\text { density }\end{array}$} \\
\hline & $40-100$ & $100-200$ & $200-300$ & $300-400$ & $>400$ & \\
\hline $\begin{array}{l}\text { Head (no. of } \\
\text { tanks) }\end{array}$ & 8 & 2 & 1 & 0 & 1 & 130.35 ha \\
\hline $\begin{array}{l}\text { Well density (no. } \\
\text { of wells/ha) }\end{array}$ & 0.43 & 0.37 & 0.41 & 0.3 & 0.37 & 0.3 \\
\hline Tail (no. of tanks) & 9 & 8 & - & - & - & 92.43 ha \\
\hline $\begin{array}{l}\text { Well density (no. } \\
\text { of wells/ha) }\end{array}$ & 0.45 & 0.47 & & & & 0.46 \\
\hline
\end{tabular}

Source: Prepared by authors based on Palanisami (2000); Palanisami \& Easter (2000). 
Table 5.12 Well Density Influenced by Tank Location and Catchment Related Factors in the Tank Cascade

\begin{tabular}{llllll}
\hline No. & Parameter & \multicolumn{3}{c}{ Head } & \multicolumn{3}{c}{ Tail } \\
\cline { 3 - 6 } & & $P U$ & $P W D$ & $P U$ & PWD \\
\hline 1. & No.of tanks & 28 & 12 & 23 & 17 \\
2. & Mean command area (ha) & 13.0 & 130.3 & 20.8 & 92.4 \\
3. & Free catchment/command area $\left(\mathrm{km}^{2} / \mathrm{ha}\right)$ & 0.083 & 0.048 & 0.12 & 0.062 \\
4. & Combined catchment/command $\mathrm{area}\left(\mathrm{km}^{2} / \mathrm{ha}\right)$ & 0.205 & 0.077 & 1.30 & 0.36 \\
5. & Annual water storage per ha of command & 0.011 & 0.010 & 0.063 & 0.047 \\
& area (million cubic meters) & & & & \\
6. & Ratio of free to combined catchment & 0.77 & 0.77 & 0.20 & 0.24 \\
7. & Well density (no. of wells/ha) & 0.63 & 0.37 & 0.65 & 0.46 \\
\hline
\end{tabular}

Source: prepared by authors based on Palanisami (2000); Palanisami \& Easter (2000).

77 percent of the total catchment in the head reaches (in both PU and PWD tanks), it was only about 20-25 percent of total catchment in the tail reaches (in both PU and PWD tanks). This low figure reflects an expected phenomenon because, as one moves down towards the tail reach in a chain of tanks, the intercepted catchment continues increasing as each of the tanks in the tail reach shares the catchment of all the upper tanks, although its own catchment is limited. Normally, it is assumed that $1 / 5$ of the free catchment is a so-called intercepted catchment. However, the ratio of free catchment to command area is higher in the tail of the chain for both the PU and PWD tanks. Moreover, the water supply in terms of annual storage per hectare of command area is also higher in the tail in both PU and PWD tanks. The well density (number of wells per ha) was approximately 0.50 in all tank groups, except for the PWD tanks in the tail reach, where it was lower at 0.37 (Table 5.12).

The higher contribution of wells in the head reach is mainly attributable to the inadequacy but certainty of tank water supply in the head compared tothe tail. Smaller tanks have a higher water inadequacy because of encroachment and siltation.

\subsection{Other factors influencing well distribution in tanks}

In addition to the location of tanks in the cascade, other factors determine the distribution of wells in the tank commands (Table 5.13). As discussed earlier, beyond rainfall patterns and tank water supply availability, other factors such as overall tank performance, O\&M expenditures spent and revenues realized from tank multiple uses also influence the well density in the tank command area. Tanks that performbetter in terms of irrigating more 


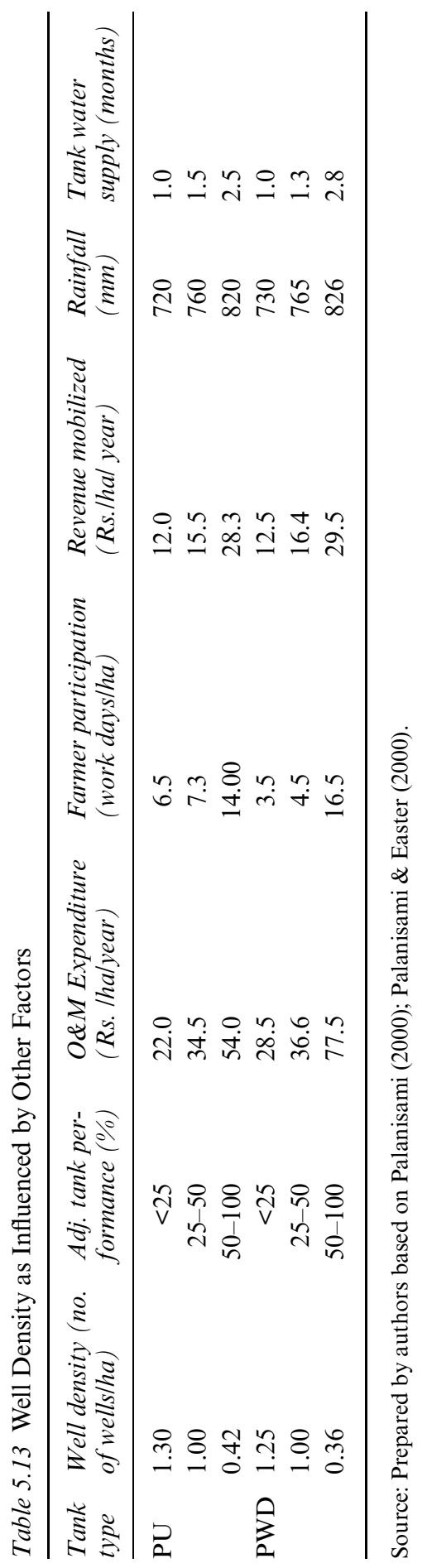


command area, that are able to spend larger O\&M budgetson tank maintenance and collecting revenue (tax) from the tanks' multiple uses therefore have a positive influence on well development in the tank commands. Unusually, some tanks depend purely upon wells. These tanks have a low performance level. They act as percolation tanks deriving tank benefits in terms of well recharge.

\subsection{Low farm income, well failure and lack of electricity supply}

In field surveys, many farmers reported that they were unable to cultivate rice successfully, which reduced crop production because of erratic rainfall and tank filling. Observations show that in 7-8 out of 10 years farmers incurred crop losses that left them with no income for well investment (Table 5.14). This lack of financial resources is compounded further by increasing levels of well failure, which is caused mainly by poor tank filling and poor groundwater recharge. Even after deepening the wells, farmers were unable to draw sufficient water from them, which again discouraged farmers from investing in them. Even for those farmers who could afford to put their money into well development using income from non-farm sources, they were unable to do so because it takes 10-15 years to acquire the necessary free electrical connections. For that reason, they postpone their investment.

\section{Sustaining tank irrigation through time-tested measures}

Recent heavy rains in the state and the expected future climate-changeinduced events (more droughts, fewer rainy days, and more intense rains) have increased emphasis on tanks for rainfall storage and management. The total storage capacity of all tanks is about $9,840 \mathrm{Mm}^{3}$ (million cubic meters) compared to the $6,896 \mathrm{Mm}^{3}$ provided by all the major and medium reservoirs in the state. However, because of tank deterioration, it can be inferred that the current storage capacity probably stands at $6,790.5 \mathrm{Mm}^{3}$.

Table 5.14 Production Loss and Well Failure Contributing for Poor Well Investment

\begin{tabular}{llll}
\hline Districts & $\begin{array}{l}\text { Production and income } \\
\text { loss (no. of years out } \\
\text { of 10 years) }\end{array}$ & $\begin{array}{l}\text { Well fail- } \\
\text { ure (\%) }\end{array}$ & $\begin{array}{l}\text { Long waiting periods for new } \\
\text { electricity connections (\% of } \\
\text { farmers reported) }\end{array}$ \\
\hline $\begin{array}{l}\text { North (no. of } \\
\text { tanks surveyed 59) }\end{array}$ & $7-10$ & 45 & 98 \\
$\begin{array}{l}\text { South (no. of } \\
\text { tanks surveyed 67) }\end{array}$ & $8-10$ & 63 & 95 \\
\hline
\end{tabular}

Source: Survey data by authors. 
About 30 percent capacity is lost because of siltation and encroachment; 1 percent is lost because of defunct tanks. Once the tank storage capacity is revived, groundwater development will also be possible through appropriate interventions. Annual groundwater draft and feasible number of wells provide some scope for expanding well irrigation in tank commands. It also acts as an upper limit for well expansion. Using the current tank situation and the future potential for tank and well irrigation, different activities are suggested under the following five scenarios (Table 5.15).

\subsection{Partial tank desilting}

Siltation strongly affects tank storage. Silt is trapped in tanks because of sedimentation and has reduced their storage capacity by $30-35$ percent to date.The cost of desilting these tanks might vary from Rs.60 to Rs. $100 / \mathrm{m}^{3}$ depending upon the location, where about 70 percent of it is attributable to the transportation cost. Given the high cost of desilting as well as difficulties related to disposal of the huge volume of silt, partial desiltation (i.e., desilting in selected (deeper) parts of the tanks covering 30 percent of the water spread area to store more water) is recommended. Partial/full desilting is included in many tank rehabilitation programs in the southern states funded by the World Bank (GOAP, 2007; GOK, 2012; GOTN, 2015). Moreover, NGOs such as the Dhan Foundation also concentrated their works on partial desilting with funding from state government programs (Dhan Foundation, 2014). Under the recent World Bank IAMWARM project, about 5,000 tanks were covered during the last five years (Government of Tamil Nadu, 2015). In all, 18-20 percent of the tanks in the state have been covered to date as part of tank rehabilitation initiatives.

Silt disposal is the major obstacle faced by most desilting programs; transporting it across fields is a challenge. Until the 1980s, farmers removed tank silt (the top $0.2 \mathrm{~m}$ ) using their bullock carts during summer. Thereby, tank storage was maintained. During the mid-1980s, when a social forestry program was introduced into the tank foreshore and water catchment areas in the state, farmers were not allowed to enter tanks for desilting. Slowly farmer level desilting disappeared and with it the bullocks also reduced because it was not economical to maintain the bullocks without desilting work. In recent tank desilting programs, most silt taken upto a depth of 1-1.5 m using machines was used in bund strengthening and road making. Only a very small share (less than 1 percent) of the silt is used as manure for fields because only the top layer (about $0.2 \mathrm{~m}$ ) has value as fertilizer. Subsequently, in early 2000, the state government issued orders to stop social forestry programs in tanks to pave the way for tank desilting. Many farmers reported that because of the intrusion of shrubs or small trees (specifically Prosophis) in water catchment areas, even the removal of a minimal quantity of silt is difficult. Furthermore, in command areas, because of frequent failures of rains and the abandonment of cultivation, 


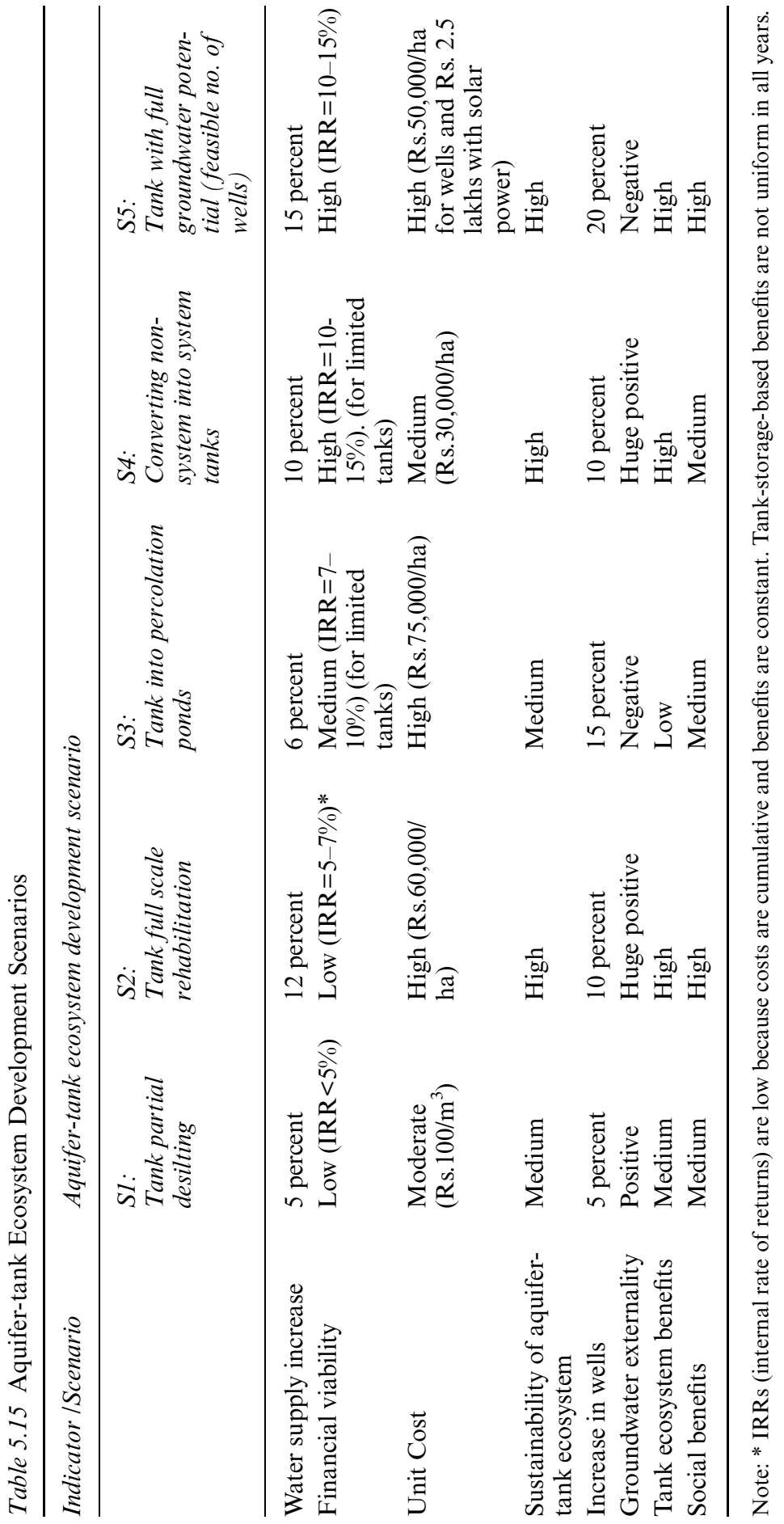


Prosophis is spreading. Farmers reported that it would cost Rs.10,000/acre to remove them, which is almost equal to 60 percent of the cost of rice cultivation. In some urbanized tanks, the silt (red loam texture) is used for brick making. A recent report has described that partial desilting and social forestry in the tank foreshore (instead of water spread) will have a higher pay-off because social forestry (mostly Acacia var.) will prevent silt inflow into the tanks (Palanisami et al., 2010).

\subsection{Full scale tank rehabilitation}

A major tank rehabilitation program was implemented in the state between 1984-85 and 1994-95 with financial aid from the European Economic Community (EEC). It used a standard package approach with the same set of rehabilitation strategies (mainly bund strengthening, canal lining, sluice repairs, and on-farm development work) for all tanks irrespective of their physical condition and need (Palanisami, 2005). For greater cost effectiveness, selective rehabilitation strategies must be identified to suit different tanks. During implementation, tank chains/cascade approaches can be followed rather than an isolated tank approach so that the surplus flows from upper tanks can be diverted to other downstream tanks, thereby mitigating flood damage.

As such, about 96 percent of all tanks are regarded as fit for rehabilitation, with an irrigated area of around 7.5 lakh ha compared to their potential of about 9 lakh ha. Regarding the type and cost of rehabilitation strategies, about 5 lakh ha can be rehabilitated with full scale selective rehabilitation at a cost of Rs.60,000/ha and the remaining 2.5 lakh ha with a moderate rehabilitation cost of Rs.35,000/ha. Each district administration can be given the responsibility of implementing the rehabilitation program with tank-specific rehabilitation strategies involving government departments, local panchayats, research institutions, NGOs, and tank farmer groups in a participatory role. It is expected that about $8-10$ percent of the tank supplies can be augmented via full-scale rehabilitation. A "before and after" study of tank rehabilitation in Tamil Nadu has exhibited a mixed response to tank rehabilitation because poor maintenance of the rehabilitated structure causes poor tank performance even if the tank water supply period is increased marginally (5-10 days) (Palanisami, 2005). Nevertheless, tank rehabilitation is expected to help improve the ecosystem-related multiple use benefits, which are steadily decreasing (Palanisami et al., 2011b). The Government of Telangana has planned to repair 9,306 tanks every year (20 percent of total tanks) with an eventual target of restoring all 46,531 tanks in five years, in a phased manner under Mission Kakatiya (Government of Telangana, 2015).

\subsection{The conversion of tanks into percolation ponds}

Of all tanks, about 1 percent are defunct or absent. About half are already performing as percolation tanks, recharging the groundwater. Therefore, 
those tanks not used for direct irrigation or tanks that are getting less than 40 percent tank storage in most years can be used to enhance water storage by deepening the storage area to convert them into percolation ponds and by encouraging farmers to invest in private wells in the command area. Because the securing of electrical connections provides a major barrier to well investment, necessary reforms in providing electrical connections quickly in rural areas can be considered. The Gujarat model of Jothigram with separate feeders for rural areas should be examined. Simultaneously, solar power pumpsets with available (80 percent) subsidies are useful. In addition to partial desilting, to enhance the storage area, costs incurred for a 300 feet well will be about Rs.2.5 lakhs (drilling cost Rs.50,000 plus the 3-5 hp. solar pumpset Rs. 2 lakhs with 80 percent subsidy). During this process, some investment in creating watershed structures such as check dams and percolation ponds in tank-intensive regions (Rs.20,000/ha) can be diverted to tank rehabilitation. Such investment can minimize the duplication of investment in water-harvesting structures. Earlier reports have described that conversion of tanks into percolation ponds can raise crop productivity and income (Nanthakumaran and Palanisami, 2012).

\subsection{Converting non-system tanks into system tanks}

Some non-system (rainfed) tanks can be converted into system tanks, thereby providing 1-2 fillings by linking the tanks from nearby rivers and reservoirs and by diverting the excess flows during heavy flooding. The cost will include only excavating feeder canals to take water from nearby rivers or reservoirs. In fact, 12 percent of the state's tanks are system tanks. Their performance (in terms of irrigated area and crop yield) is much higher than that of non-system tanks. It is expected that about 1 percent of existing non-system tanks (about 390 tanks) can be converted into system tanks. However, a major issue in this initiative is expected to be the identification of the proper river and tank cascade links and ascertaining their feasibility by considering existing flows and the excess water available from rivers during heavy rains. The proposed Athigadavu and Avinashi scheme is aimed at providing rainfed tanks near the Coimbatore and Tiuppur districts with 1-2 additional fillings (Government of Tamil Nadu, 2011).

\subsection{Tanks with full scale groundwater development}

Considering the total number of feasible wells using annual net groundwater draft, a roughly 21 percent increase is possible. As discussed earlier, comparing the existing and potential number of wells, the northern region has only a 9 percent gap compared to the 50 percent gap in the southern region. Because the northern region has already reached the potential level, emphasis can be assigned for the southern region to adopt this well expansion strategy which will engender a threshold level of 1 well/3 ha of NSA (compared to the 
present level of 1 well/4 ha of NSA) as identified in the field survey. Additional costs incurred for a 300-foot-deep well are expected to be about Rs.2.5 lakhs: drilling cost Rs. 50,000 plus the solar pumpset Rs. 2 lakhs with 80 percent subsidy(Government of Tamil Nadu, 2015). This strategy can be implemented in a phased manner by farmers using loans from commercial banks. To complement well intensification, tanks must be maintained properly so that groundwater recharge will increase and so that well failure will decrease. This win-win situation benefiting both tanks and wells will make tank eco-systems sustainable as other multiple uses, especially fishery and livestock drinking, are expected to add value to the tanks (Palanisami et al., 2011b).

Alone or in combination, the strategies above are possible, but their financial feasibility must be examined because, when strategies are combined, costs are cumulative but benefits are constant. The ranking of the suggested scenarios (in terms of scale and size of investments) can be: S1, S3, S4, S2 and S5. When the strategies are implemented, the overall water supply in a normal rainfall year will increase by about 20 percent. Moreover, the tank irrigated area will increase by about 30 percent from present levels.

\section{Summary and conclusions}

Tamil Nadu state has about 39,366 tanks with varying sizes and types with an irrigation potential of about 9 lakh ha. Over the years, tank performance has declined. It is now only about 5 lakh ha. Lack of adequate rain, poorly maintained tank structures, encroachment in tank catchments, inefficient water management practices, and the non-functioning of tank-related village institutions have contributed greatly to this decline in tank-irrigated areas.

Given climate change predictions with higher variation in rainfall patterns, tanks are expected to present more problems in the near future. At the same time, tanks offer scope for storing more rainfall runoff from intensive cyclonic rains. Given this situation, two important strategies have emerged from this chapter: (1) enhanced groundwater supplementation for increasing the tank irrigated area in the deficit rainfall years, (2) improved tank storage capacity to store more water during heavy cyclonic rains as predicted in the climate change scenarios. Once the tank storage capacity is revived, enhanced groundwater recharge will also be possible through appropriate intervention. Even though details related to different tank improvement options outlined in this chapter are important in improving the overall tank performance, they have to be carefully examined to fit well into future tank investment plans. In this context, the following questions are important in strengthening the future tank research and implementation programs:

\section{Research questions}

1. Does the uncertain rainfall with spacial and temporal variability make the current multiple uses of tanks (such as irrigation, fishery, social 
forestry, silt, domestic and livestock water uses) sustainable given the opportunity cost of scarce water, labour and land?

2. What is the economic impact of tank desilting? Who benefits from such interventions - the local community, the contractors or the individual farmers?

3. How will the conversion of tanks into percolation ponds address the question of equity in sharing the tank benefits?

4. How will labour migration from tank villages to cities eventually affect the future of tank management, land ownership patterns, and groundwater investment?

5. What are the stabilization values of groundwater supplementation in tanks under varying tank storages?

6. What are major constraints in using some of the Government's ongoing programs like Mahatma Gandhi National Rural Employment Guarantee Scheme (MGNREGS) for reviving tank storage?

7. Why, in regard to tank management, is the traditional Kudimaramath (cooperative repair work by local community) not workable now?

8. What are the social benefits and costs of reviving the tank water users' organizations?

9. Can we learn lessons for tank management from experiences across Asia?

An inter-disciplinary team of social scientists and irrigation engineers could supply some answers to the questions above that would facilitate tank rehabilitation in a phased manner with investment options.

\section{Note}

* The original version of this chapter was read at the 8th INDAS International Conference 'Toward Sustainable Development of India and South Asia'held in Kyoto University, December 17-18, 2016.

\section{References}

Dhan Foundation (2014). Annual Reports, various periods, Madurai, Dhan Vayalagam.

Government of Andhra Pradesh (2007). World Bank India: Andhra Pradesh Community Based Tank Management Project ( APCBTMP), New Delhi, The World Bank.

Government of Karnataka (2012). World Bank India: Karnataka Community Based Tank Management Project, Bangaluru, The World Bank.

Government of Tamil Nadu (2011). Avinashi-Athikadavu Scheme, Preparatory works, Coimbatore: WRO.

Government of Tamil Nadu (2012a). Minor Irrigation-Progress of Tank Program Implementation, Chennai: WRO.

Government of Tamil Nadu (2012b). TNIAMWARM Project, Chennai: Water Resources Organization (WRO).

Government of Tamil Nadu (2015). Agricultural Engineering Department-Various Documents on Progress of Solar Power Program, Chennai: Agriculture Department, Govt. of Tamilnadu. 
Government of Telangana (2015). Mission Kakatiya, Hyderabad: Irrigation and CAD Department.

Mosse, D. (1996). Local Institutions, Ecology and History in South Indian Tank Irrigation Systems, Centre for Development Studies, University of Wales, UK.

Nanthakumaran, A., and K. Palanisami (2012). "Efficiency of Sugarcane Production under Tank Irrigation Systems in Tamil Nadu, India," Journal of Environmental Professionals, Sri Lanka, vol. 1, pp. 1-15.

Palanisami, K. (2000). Tank Irrigation-Revival for Prosperity, New Delhi: Asian Publication Services.

Palanisami, K. (2005). "Sustainable Management of Tank Irrigation Systems in South India," Working Paper Series No. 2. Kyoto, Japan: Afrasian Centre for Peace and Development Studies.

Palanisami, K., and K. W. Easter (2000). Tank Irrigation in the 21st Century-What Next?, New Delhi: Discovery Publishing House.

Palanisami, K., M. Giordano, K. Kakumanu, and C. R. Ranganathan (2011a). "The Stabilization Value of Groundwater: Evidence from Indian Tank Irrigation Systems," Hydrogeology Journal. DOI: 10.1007/s10040-011-0793-3. November 4.

Palanisami, K., R. Meinzen-Dick, and M. Giordano (2010). "Climate Change and Water Supplies: Options for Sustaining the Tank Irrigation Potential in India," Economic and Political Weekly, vol. XLV (26\&27), June 26-July 9, pp. 183-90.

Palanisami, K., R. Meinzen-Dick, M. Giordano, and B. Van Koppen (2011b). "Tank Performance and Multiple Uses in Tamil Nadu, South India-Comparison of Two Time Periods (1996-97 and 2009-10)," Irrigation and Drainage Systems. DOI: 10.1007/s10795-011-9114-1. 
6 Ahar

\title{
A traditional irrigation system in Southern Bihar
}

\author{
Tetsuo Satoh
}

PROFESSOR AT DEPARTMENT OF GEOGRAPHY, KOMAZAWA UNIVERSITY

\section{Overview of irrigation systems in Bihar state}

In Bihar State, the control of water resources is a crucially important factor affecting agricultural development (Fujita, 2014: 66-67). Table 6.1 presents percentages of irrigated area by water source to the total cultivated area, based on Village Level Amenity Data (2001). ${ }^{1}$ The percentage of total irrigated area in Bihar State amounts to 59 percent with a regional difference of 21 percent in terms of standard deviation based on block level data. Two predominant sources of irrigation are canals and tube wells serviced without electricity, such as diesel-powered boring pumps. Overall, the canal irrigated area is larger than that of the tube well without electricity, although their coefficients of variance suggest that the latter extends more widely throughout the state than canal irrigation. Other sources of irrigation appear to be of small scale, each covering less than 5 percent of the total cultivated area.

A traditional irrigation system using ahar reservoirs exists in southern Bihar. According to Fukuda (1976: 130), low dikes are constructed on a gentle slope near hilly areas to reserve water temporarily, and to irrigate paddy fields on the downstream side of the dike. Koul et al. (2012: 266-267) pointed out that the ahar differs from a tank in that its bed is not dug and that it is used to grow a rabi crop. Furthermore, ahar of two types exist with regard to the water supply. The ahar water is supplied either through a canal (pyne) in the case of an 'ahar-pyne' system or by natural drainage after rainfall in the case of a 'rainfed ahar'.

Pant (1998: 3134-3137) studied ahar-pyne system operation for the case of Machala Ahar, primarily emphasizing its socioeconomic features. This ahar is located near Kalpa Village in Jehanabad District (Map 6.1). In this village, rice is grown as the main crop, partly depending on irrigation with ahar water, whereas wheat is another major crop occupying half of the cropped area. This ahar, constructed in the second half of the 19th century, had been managed by a zamindari family. Today, the Department of Minor Irrigation is responsible for ahar maintenance, but local farmers conduct 
Table 6.1 Percentage of Irrigated Area to Total Cultivated Area by Water Source in Bihar

\begin{tabular}{lclll}
\hline Irrigation Water Source & $\begin{array}{l}\text { Whole } \\
\text { State }\end{array}$ & $\begin{array}{l}\text { Average of } \\
\text { Block Data }\end{array}$ & $\begin{array}{l}\text { Standard } \\
\text { Deviation }\end{array}$ & $\begin{array}{l}\text { Coefficient } \\
\text { of Variation }\end{array}$ \\
\hline $\begin{array}{l}\text { Government and Private } \\
\text { Canal }\end{array}$ & 18.8 & 16.4 & 22.2 & 1.35 \\
Tube Well without & 17.6 & 19.4 & 16.5 & 0.85 \\
Electricity & & & & \\
Well without Electricity & 3.9 & 4.2 & 6.4 & 1.53 \\
River and Waterfall & 3.2 & 3.3 & 4.7 & 1.45 \\
Tube Well with Electricity & 2.4 & 2.6 & 4.5 & 1.69 \\
Tank & 2.0 & 2.0 & 3.4 & 1.74 \\
Well with Electricity & 1.4 & 1.5 & 3.6 & 2.41 \\
Lake & 0.3 & 0.3 & 0.8 & 2.88 \\
Others & 9.0 & 8.7 & 12.8 & 1.47 \\
Total & 58.7 & 58.5 & 21.3 & 0.36 \\
\hline
\end{tabular}

Source: Village Level Amenity Data (2001).

minor repairs by themselves. The water is not always sufficient. Therefore, villages in the beneficiary area have experienced mutual water conflicts.

The ahar water is supplied through a pyne from an intake located on the east bank of the Morhar River about $4 \mathrm{~km}$ west of the village. This pyne connects to the ahar through a $1.5 \mathrm{~m}$ wide $\times 2 \mathrm{~m}$ high inlet water gate. The main outlet of the overflow spillway with a small gate $1 \mathrm{~m}$ wide $\times$ $1.5 \mathrm{~m}$ high is installed on the outer gutter along the dike about $80 \mathrm{~m}$ north of the inlet. The gutter supplies water to the distribution channels extending through rice fields in the north. These gates, which were built more than 20 years ago and which were improved by the government five years $\mathrm{ago}^{2}$ are operated by the villagers of Kalpa. Three smaller outlets, called dhuga, are operated by nearby villagers when necessary.

According to the villagers, such water shortages hindering rice transplantation at the proper time occur twice or thrice a decade. Silting in the pyne is regarded as a major hindrance to favorable water supply. For that reason, dredging is expected to revitalize the ahar-pyne system. Reportedly, an embankment of the Kinjar-Kurtha highway to the east of the Punpun River, from which the Morhar derives, has changed its drainage system in the eastern part of the district, reducing the irrigation water supplied to Machala Ahar.

The land inside the ahar is usually left unused during the rainy season, but pulses and other minor crops can be grown in the early rabi season. A satellite image of late December depicted in Map 6.2 (left) shows the gray part as smooth in texture, with grass vegetation, which is distinguishable from the surrounding rice fields after harvest. The ahar might also strongly 


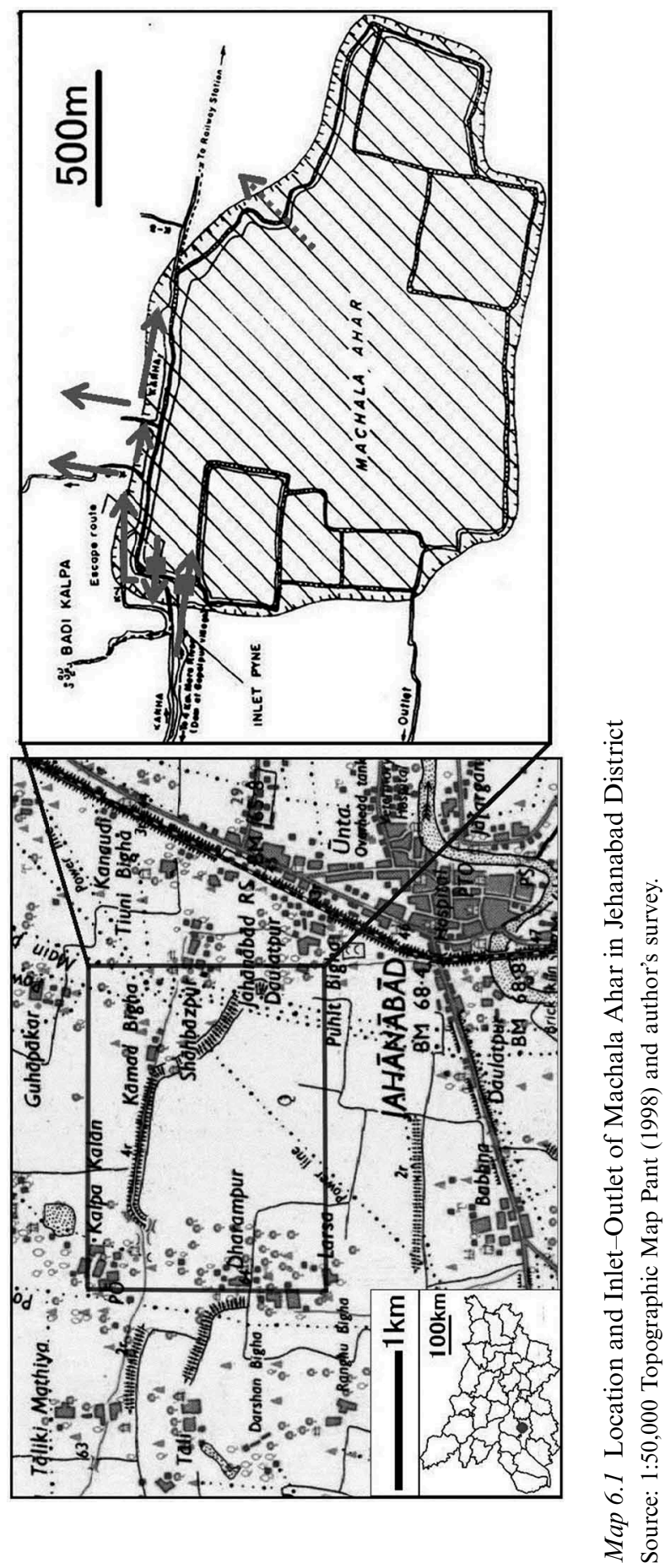



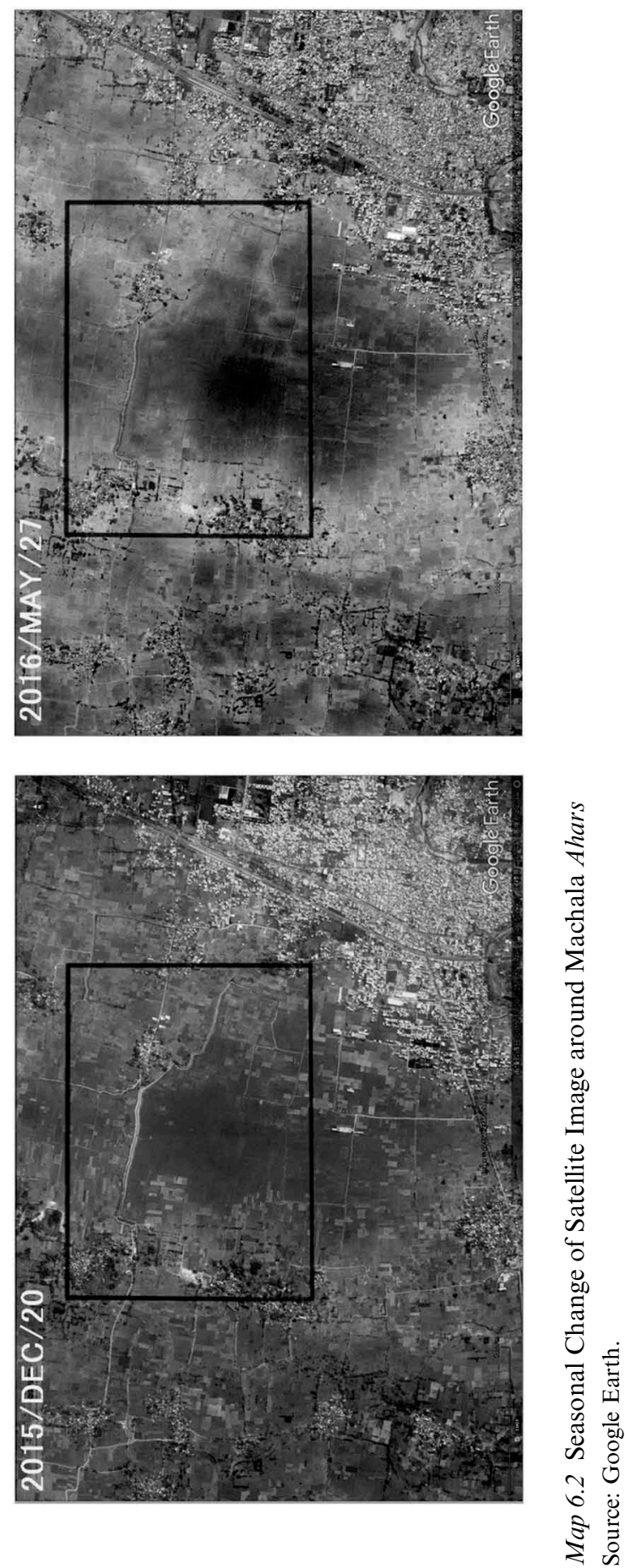
influence the agricultural environment such as soil conditions in the dry season. The darker part in the satellite image of May, which lies inside the ahar, represents land with higher soil moisture. Consequently, the ahar serves not only for rice cultivation, but also for follow-up cultivation in the early rabi season.

Pant (ibid: 3133) referred to the importance of the ahar-pyne system and reported a government estimate that the area under this irrigation system accounted for 12 percent of the total irrigated area in Bihar in 1997. Examining the present situation of this traditional system is important. Although this system is not itemized in the Village Level Amenity Data described above, areas operating under this system are apparently included in 'others'. Based on the results of statistical data analyses and the author's field survey with interpretation of topographic maps and satellite images, this chapter presents locational aspects and geographical distribution of ahars in southern Bihar.

\section{Variations and locational aspects of Ahars}

In this section, two examples of ahars are described, mainly based on the author's field observations in March 2015, and in February and August 2016. To compare these examples with the case of Machala Ahar and Kalpa Village, Table 6.2 presents a profile of the villages in charge of the ahars. Figure 6.1 shows a cross-section of the ahar dikes surveyed.

Budhauli Ahar, for which water is supplied through Jirain Pyne, is located in the central part of Nawada District (Map 6.3). This case affords another example of an ahar-pyne system. Actually, Budhauli is a rural village with a large temple tank and the ruins of a residence of a zamindari family, who constructed and operated this ahar-pyne system. The water is conveyed through a nearly $20-\mathrm{km}$-long canal from the intake on the right bank of the Sakri River. The canal reaches the ahar from the southwest and connects to the inner gutter along the dike. The pyne has no inlet water gate.

The Budhauli Ahar dike is higher by $2 \mathrm{~m}$ than Machala Ahar, but it has a reinforced revetment with bricks at $3 \mathrm{~m}$ height, or equivalent to Machala Ahar's top. This configuration suggests that the original dike was raised and improved during the zamindari period. The main outlet is an 8-m-wide overflow spillway that is lower by $1 \mathrm{~m}$ than other parts of the dike (Figure 6.2, right). Several small outlet ducts exist at the base of the dike. To the north of these outlets lies a large beneficiary area of several-hundred-hectare rice fields with plot-to-plot irrigation. At least three rainfed ahars are recognized in the village from satellite images.

In August 2016, most of the land inside the ahar was submerged to a depth of less than $1 \mathrm{~m}$, but the farmers intended to grow pulses there in the early rabi season (Figure 6.2, middle). Satellite images presented in Map 6.3 confirm this cropping pattern. In the image taken in December 2015, 


\section{Tetsuo Satoh}

Table 6.2 Profiles of Villages in Charge of Surveyed Ahars

\begin{tabular}{|c|c|c|c|}
\hline Ahar Name & Machala & Budhauli & Biskruwa, etc. \\
\hline Village Name & Kalpa & Budhauli & Siriyawan \\
\hline Block & Jehanabad & Pakribarawan & Mohanpur \\
\hline District & Jehanabad & Nawada & Gaya \\
\hline Village Area in ha & 630 & 756 & 334 \\
\hline No. of Household & 881 & 909 & 358 \\
\hline $\begin{array}{l}\text { Total Cultivated Area } \\
\text { in ha }\end{array}$ & 588.45 & 593.65 & 252.96 \\
\hline $\begin{array}{l}\text { Irrigated Area in } \\
\text { ha }(\%)\end{array}$ & $337.80(57.4)$ & $345.68(58.2)$ & $150.96(59.7)$ \\
\hline $\begin{array}{l}\text { Primary Irrigation } \\
\text { Water Source }(\%)\end{array}$ & $\begin{array}{l}\text { Tube Well without } \\
\text { Electricity (54.9) }\end{array}$ & Others (75.1) & Others (65.7) \\
\hline $\begin{array}{l}\text { Secondary Irrigation } \\
\text { Water Source }(\%)\end{array}$ & Others (21.4) & $\begin{array}{l}\text { Tube Well with } \\
\text { Electricity (16.4) }\end{array}$ & $\begin{array}{l}\text { Well without } \\
\text { Electricity (34.3) }\end{array}$ \\
\hline
\end{tabular}

Source: Village Level Amenity Data (2001).

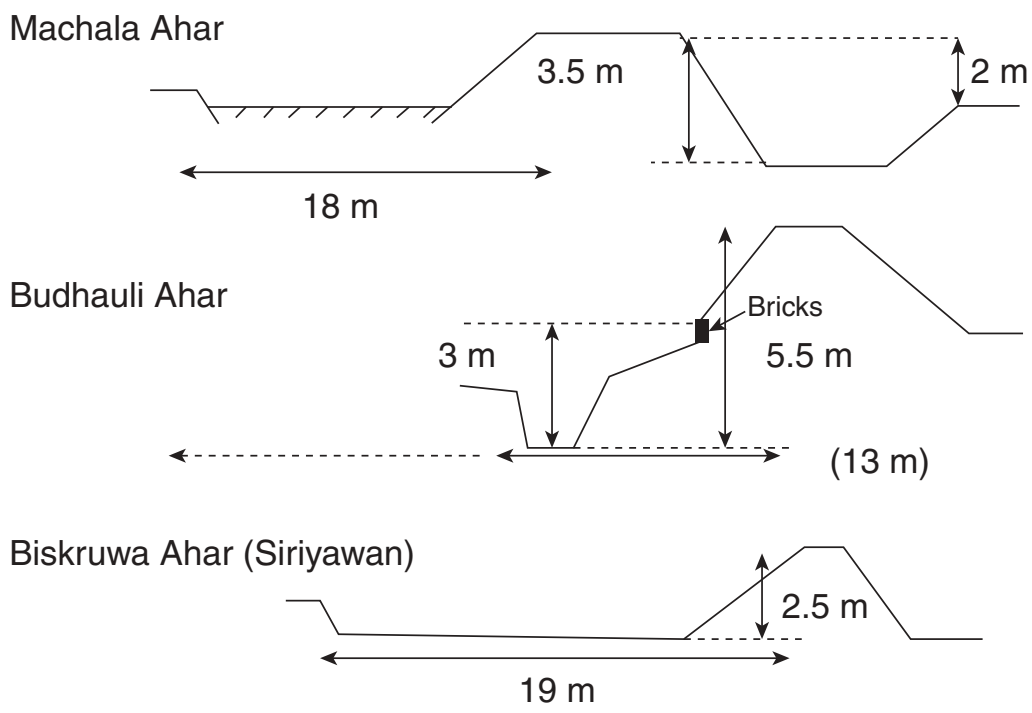

Figure 6.1 Cross-section of Dikes of Surveyed Ahars

immediately after rice harvest, the land inside the ahar is covered with grass vegetation. In the image taken in February 2017, the land is without vegetation, giving contrast to the surrounding fields seemingly planted to wheat, which is shown with darker shading. 

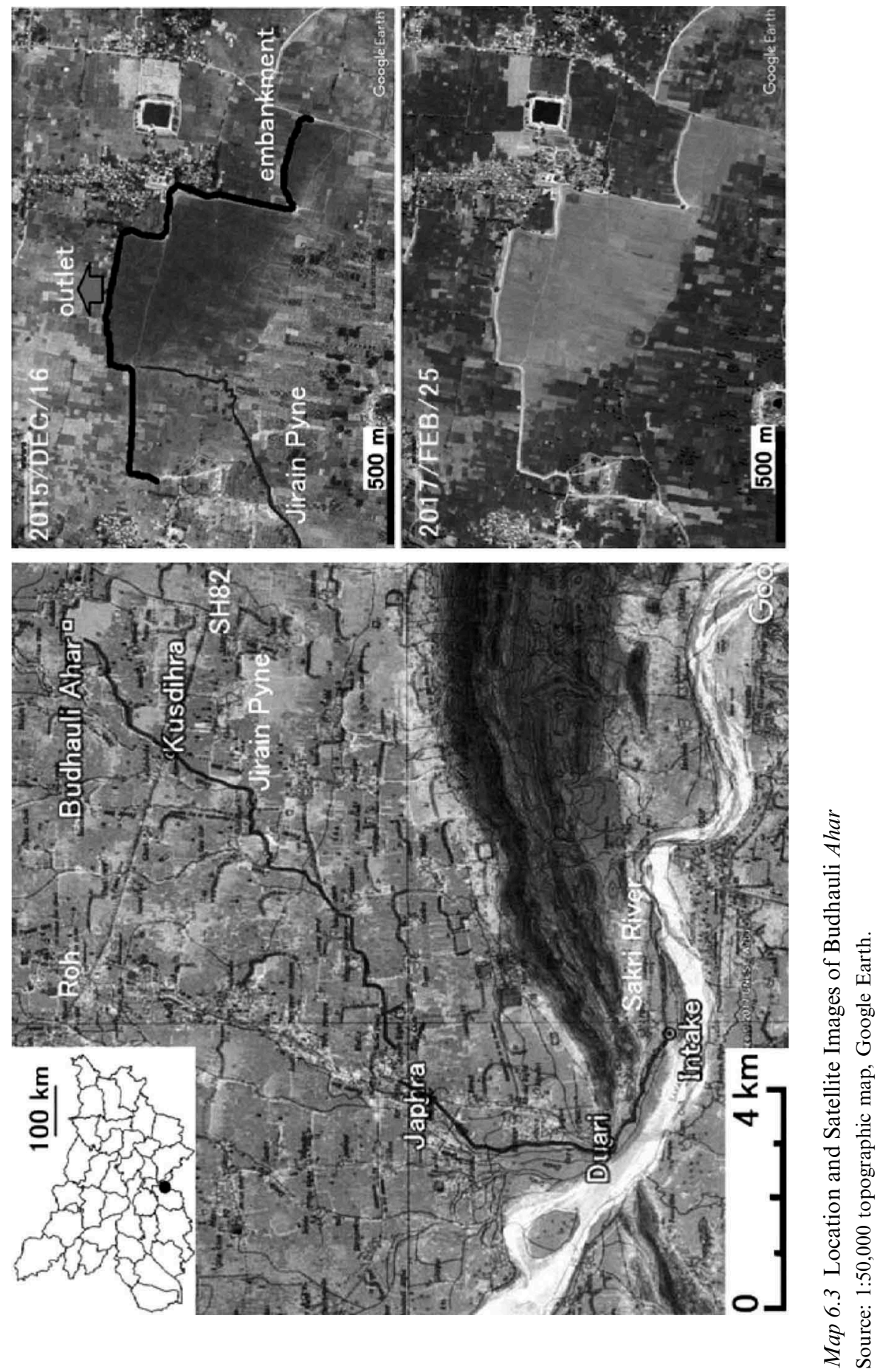

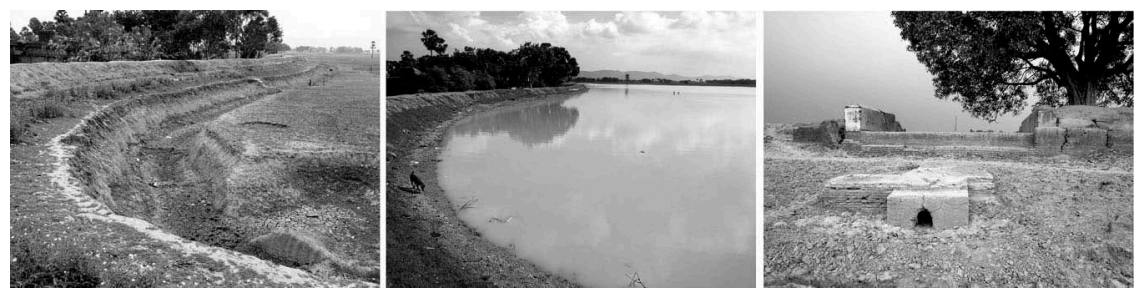

Figure 6.2 Budhauli Ahar in February (left) and August (middle), 2016 and its Outlet (right)

Today, the village panchayat maintains Budhauli Ahar, whereas the maintenance of Jirain Pyne is handled in different ways from one community to another. As described above, the origin of the canal is located about $20 \mathrm{~km}$ away from the ahar. In Duari Village, at a point $3 \mathrm{~km}$ downstream from the intake, the canal divides into five channels, one of which, called Samari Pyne, is the source of Jirain Pyne. The canal above this point is lined with concrete and is maintained by the Department of Minor Irrigation. The lower parts of these five channels are not necessarily in good condition because their maintenance depends on the local communities. At the village of Japhra, $4 \mathrm{~km}$ away from Duari, Samari Pyne divides into two. The source channel of Jirain Pyne is intermitted at the point about $1 \mathrm{~km}$ northeast of the village, according to the villagers. Jirain Pyne restarts nearly $1 \mathrm{~km}$ further down after the water runs through rice fields in the form of plot-to-plot irrigation. In Kusdihra Village located $3 \mathrm{~km}$ to the southwest of Budhauli, Jirain Pyne to the north of State Highway 82 has been improved to be $10 \mathrm{~m}$ wide with embankment whereas the southern part is left narrow without embankment. This result suggests that a large ahar-pyne system has difficulties with the maintenance of pyne rather than ahar, but it brings great benefit to local water resources for irrigation.

The second example is a group of rainfed ahars in Siriyawan Village located in the southern part of Gaya District. Siriyawan Village is less than half the size of Kalpa or Budhauli. It has no large ahar-pyne system. Although it is located on the Mohana River, its irrigation can depend only slightly on the river because the river becomes dried up during the dry season and because heavy rains during the rainy season often cause flash floods. Irrigation water during the rainy season derives through plot-to-plot irrigation or small field channels from the upper villages in the south. In the dry season, underground water is used for irrigation.

This area has gently sloping ground with a gradient of about 1:200 near the foot of Hazaribagh Plateau bordering Jharkhand State (Map 6.4). The surface water around this area originates in the protected forest (indicated as PF) on the edge of the hill. The Danor River coming from the protected forest supplies irrigation water through a small channel to Baliyari Village, 


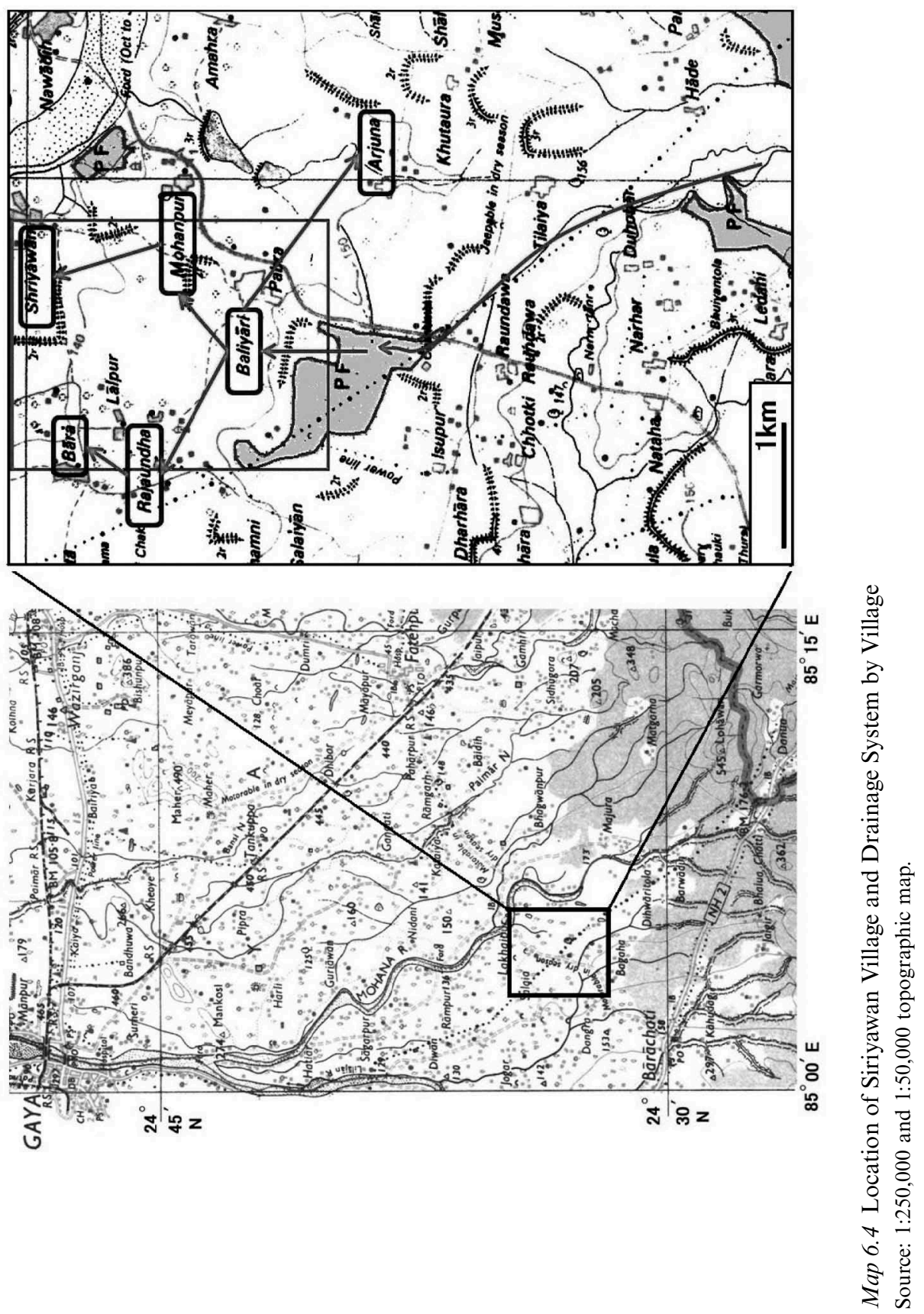




\section{Tetsuo Satoh}

where the water runs off into three directions. Siriyawan Village to the north collects the water through Mohanpur Village.

Siriyawan Village has several small ahars, reportedly built during the zamindari period. Today, they are maintained by a local group consisting of more than a dozen farmers. The members undertake routine management and minor repairs, although large-scale repairs are made once in about five years by the village panchayat, taking advantage of programs under the National Rural Employment Guarantee Act (NREGA). In a large-scale repair effort, soils in the gutters along the dikes are scooped out to restore the water reserving and conveying capacity. Heavy machines are sometimes used when the work is too difficult to complete with manual labor and draft animals alone.

The ahar management group in Siriyawan Village maintains 8 ahars and the village pond. The operation of ahar has been practised conventionally. The drainage system among the ahars is shown in Map 6.5. Drained water from Baliyari Village moves down from one ahar to another, finally discharging into the village pond or the Lalsagar River, a tributary of the Mohana. These 8 ahars are small. Each has only one or two outlets. Sometimes, the ahars are mutually connecting directly, so the outlet of an ahar is the inlet of another ahar. A ceramic or concrete duct of $30-50 \mathrm{~cm}$ diameter is set at the base of the dike, but it has no gate or valve to control drainage (Figure 6.3). Therefore, the storage and drainage of ahar results from a natural process, although the ahar itself has a structure that is the product of human effort. However, emergency operations such as those against flooding are decided at a collective village meeting.

Usually the ahars irrigate about half of the rice fields in this village. Supplemental irrigation with boring pumps is also practised almost every other year. Rice cultivation in this village starts in late May with nursery preparation. From the last week of June through August, rice is transplanted to main fields depending on the rainfall. Utilization of ahar water during the rice growing season is limited in quantitative terms, but irrigation is most important from the last week of September through the first week of October, when rice ears come out. Rice is harvested in mid-November through December, with subsequent wheat cultivation in some fields. According to the local farmers, unless broadcasting of seed is finished by the end of December, the yield of wheat will decrease by 20-30 percent. For that reason, the farmers prefer early rice varieties to late varieties, the latter of which depend more heavily on late rains.

The land inside the ahar is rarely submerged, even during the rainy season, because of the limited supply of water (Figure 6.3). Usually, it is used for rice fields during the rainy season. It is then planted to rabi crops with boring pump irrigation. The land use inside the ahar is not so much different from outside. However, the gutters are filled with water during the rainy season. Pulses are grown on the bottom in the early rabi season, which implies that a rainfed ahar is a conditional and unstable irrigation 

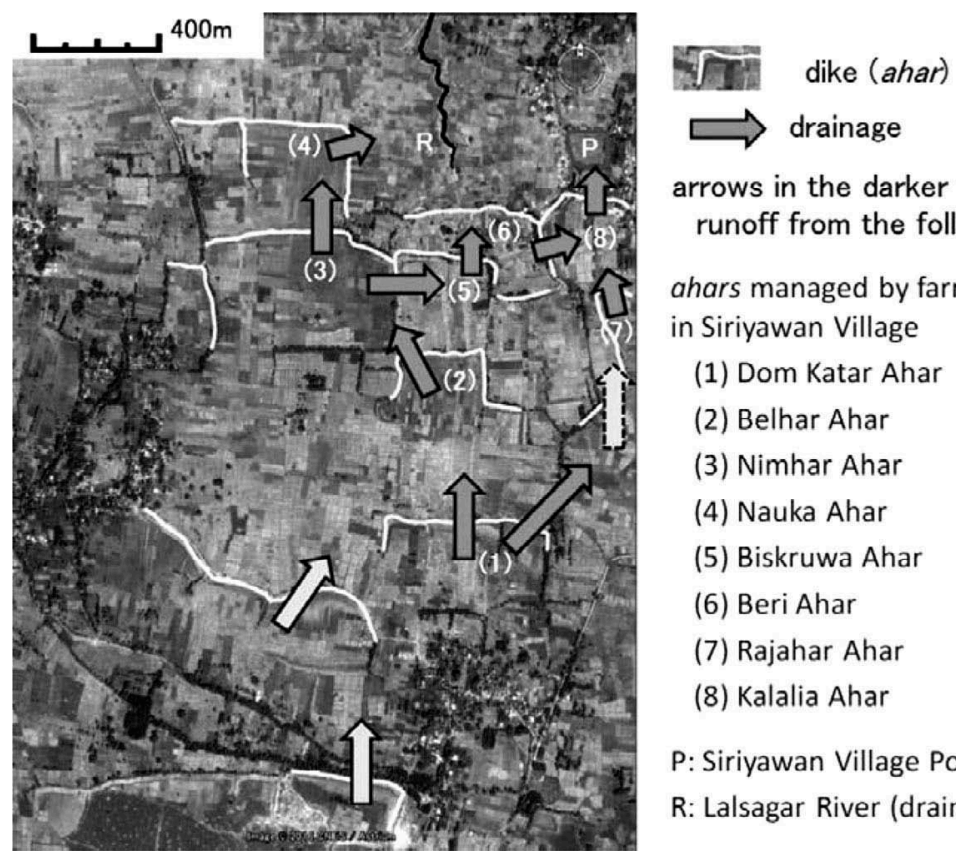

arrows in the darker tint: runoff from the following ahars

ahars managed by farmers' group in Siriyawan Village

(1) Dom Katar Ahar

(2) Belhar Ahar

(3) Nimhar Ahar

(4) Nauka Ahar

(5) Biskruwa Ahar

(6) Beri Ahar

(7) Rajahar Ahar

(8) Kalalia Ahar

P: Siriyawan Village Pond

R: Lalsagar River (drain)

Map 6.5 Ahar-to-Ahar Drainage System in and around Siriyawan Village

facility. Farmers seem to adjust to this unstable condition of irrigation by cropping patterns.

Several open wells of $10-15 \mathrm{~m}$ deep are found around the ahars. According to the villagers, irrigation water used to be drawn up by $4-5$ men with a large shadoof, or swell sweep, which was called a Barha in this area. They have apparently exploited shallow groundwater recharged by ahar. At present, these wells are abandoned. In some cases, boring pumps are installed inside the well. Irrigation using boring pumps has expanded to cover a quarter of the cultivated area in this village. The groundwater from the aquifer at $30-45 \mathrm{~m}$ depth is most often used for irrigation during the dry season, but sometimes it is not available in March, when wheat requires irrigation before harvest. In this village, an aquifer deeper than $75 \mathrm{~m}$ can provide water year-round, but it entails high costs for irrigation. Water for daily life is drawn up from this deeper aquifer using government hand pumps.

Many small rainfed ahars dot the gently sloped piedmont plain around Siriyawan Village. Actually, the maintenance conditions of these ahars differ from place to place. For example, Mero Khap Village in Mohanpur Block, located $6 \mathrm{~km}$ southwest to Siriyawan and nearer to the protected forest, 

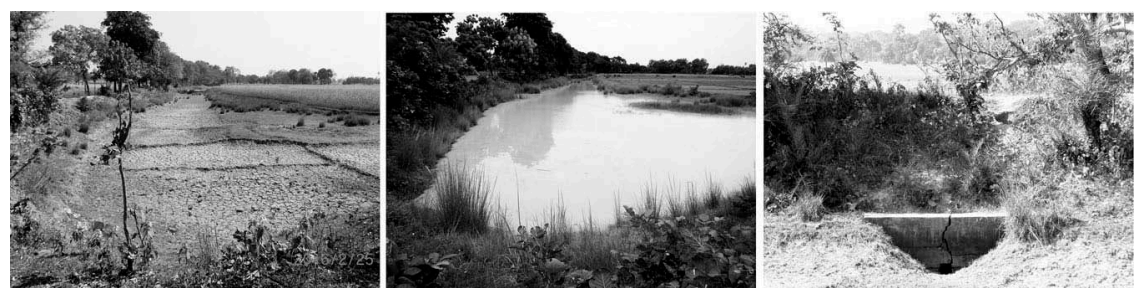

Figure 6.3 Biskruwa Ahar in February (left) and August (middle), 2016 and Its Inlet (right)

shares a small ahar with neighboring villagers. This village consists of 70 households with 90 ha of cultivated land. According to Village Level Amenity Data, the percentage of unirrigated area of this village accounts for 84 percent. According to the villagers, about 80 ha of cultivated land can be irrigated with an ahar in the west of the village, although the ahar water falls short once every three years. Presumably, the statistical data might sometimes neglect such cases of unstable irrigation.

The farmers in Mero Khap bear all ahar maintenance costs. A few leading members take care of routine operations and minor repairs. For the major repairs, goman, collective work for ahar management, is practised with the participation of 20 landowners in Mero Khap Village and 15 farmers from nearby villages. Each member serves as a male worker, or provides one for a few days, or pays cash for the work when lacking a participant worker. In the past, there was another goman group for a larger ahar in the east of the village, but it was dissolved when heavy machines became necessary for major repairs. More recently, a fence was built around the protected forest some years ago. Management of the irrigation channels has been difficult because the villagers cannot enter the water source area. According to an older villager, water shortages in the past were less frequent than they are today because of more abundant runoff from forests. Conservation of water source areas is apparently an important concern of the villagers.

In the protected forest on the slope of Hazaribagh Plateau, the runoff of rivers seems abundant. For example, even during the dry season, the upper reaches of the Mohana River, which become an underflow around Mohanpur Block, maintain a clear flow under the bridge of National Highway 2, although the water level is lower by $2-3 \mathrm{~m}$ than the maximum level during the rainy season. This area, around $170 \mathrm{~m}$ above sea level, is situated in the protected forest and is covered by an open forest that is disturbed by the nearby villagers. In general, along the national highway, a large part of the protected area lower than $200 \mathrm{~m}$ on the edge of the hills has already turned into shrubland, whereas the area above $200 \mathrm{~m}$ retains its forests. The foot of hills up to $250 \mathrm{~m}$ is covered with disturbed dry forest, whereas the 
forest over $250 \mathrm{~m}$ is dense and well protected, with a diversity of species including evergreen trees. This observation implies a favorable condition in the water resource area.

\section{Characteristics and spatial distribution of Ahar}

To analyze geographical distributions of ahar, principal component analysis (PCA) was applied to the block-level statistical data described previously. The percentages of irrigated area by water source to the total cultivated area were adopted as variables: (1) government and private canals (CNL), (2) wells without electricity (WLwoE), (3) wells with electricity (WLwE), (4) tube wells without electricity (TWwoE), (5) tube wells with electricity (TWwE), (6) tanks (TNK), (7) rivers and waterfalls (RIV), and (8) others including lakes $(\mathrm{OTH})$. The PCA results are presented in Table 6.3.

Four principal components with eigenvalues greater than 1.0 are adopted here to explain 71.6 percent of the total variance. The first component, which explains 22.2 percent of the total variance, designates 'conventional irrigation technology' in contrast to 'innovative' technologies, showing positive correlation with WLwE (loading of value 0.698), WLwoE (0.582), RIV (0.485), and TWwE (0.448) as well as negative correlation with TWwoE (-0.429). The second component, explaining 18.2 percent, has strong correlation with TWwoE (0.664), TWwE (0.619), and CNL (-0.476), connoting 'utilization of ground water' in the resource dimension. The third component (17.1 percent) is positively correlated with CNL (0.693) and WLwE

Table 6.3 Results of Principal Component Analysis

\begin{tabular}{lllll}
\hline Component & $1 s t(P C 1)$ & 2nd (PC2) & 3rd (PC3) & 4th (PC4) \\
\hline Eigenvalue & 1.78 & 1.45 & 1.37 & 1.12 \\
$\begin{array}{l}\text { Variance Explained \% } \\
\text { (Cumulative \%) }\end{array}$ & 22.2 & 18.2 & 17.1 & 14.0 \\
Loading of Value & $(22.2)$ & $(40.4)$ & $(57.5)$ & $(71.6)$ \\
CNL & & & & \\
WLwoE & -0.176 & -0.475 & 0.693 & -0.309 \\
WLwE & 0.582 & 0.059 & -0.061 & 0.365 \\
TWwoE & 0.698 & 0.365 & 0.413 & -0.047 \\
TWwE & -0.429 & 0.664 & -0.427 & 0.015 \\
TNK & 0.448 & 0.619 & 0.307 & -0.223 \\
RIV & 0.382 & -0.235 & -0.436 & -0.558 \\
OTH & 0.486 & -0.257 & -0.484 & -0.347 \\
Interpreted Dimension & Technology & Resource & Infrastructure & Particularity \\
positive & conventional & groundwater & available & indigenous \\
negative & innovative & surface water & unavailable & tank \\
\hline
\end{tabular}




\section{Tetsuo Satoh}

(0.413), but negatively correlated with RIV (-0.484), TNK (-0.436), and TWwoE (-0.427). This component is regarded as an indicator of 'availability of infrastructure', which is affected by government initiative. The fourth component (14.0 percent), with high loading on OTH (0.641) and TNK $(-0.558)$, can be interpreted as 'local irrigation method' contrasting tank irrigation with others. The nature of ahar-pyne system is similar to that of tank irrigation, but this component can discriminate areas characterized by ahar-pyne system from tank irrigation areas.

Through cluster analysis ${ }^{3}$ of component scores, 531 blocks are classified into five groups from Class $\mathrm{A}$ to $\mathrm{E}$ with the dendrogram presented in Figure 6.4. Table 6.4 presents the average component scores for the respective classes as well as their percentages of irrigated area and composition by water source. According to this table, it is possible to identify the characteristic irrigation method of each class. Class A are canal irrigation areas depending on the infrastructure and surface water with a large percentage of the irrigated area. Class B areas are characterized by the smallest percentage of irrigated area with an innovative irrigation technology of TWwoE. This class, which comprises more than half the number of blocks, seems to represent a typical irrigation situation in Bihar State. Class C is a group of blocks with conventional specific irrigation methods such as river or tank irrigation, depending less on infrastructure, whereas Class $\mathrm{D}$ are areas characterized by conventional indigenous irrigation methods

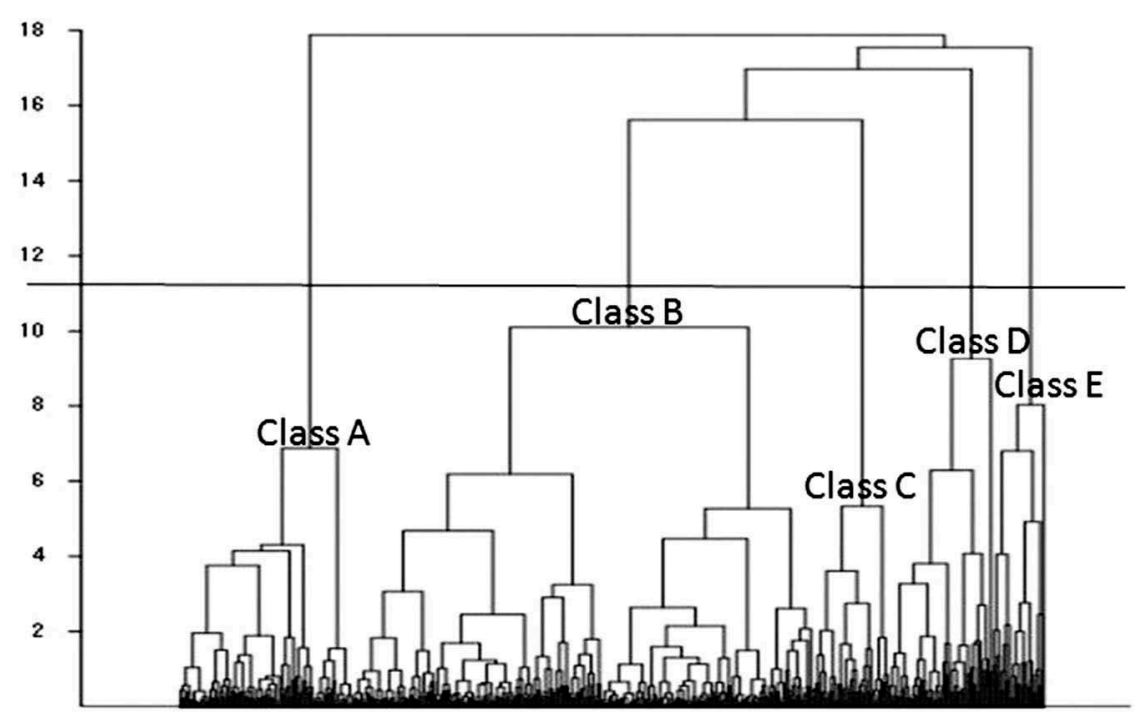

Figure 6.4 Dendrogram of Cluster Analysis 
Table 6.4 Results of Cluster Analysis

\begin{tabular}{llllll}
\hline & Class A & Class B & Class C & Class D & Class E \\
\hline $\begin{array}{l}\text { Number of Blocks } \\
\text { Average of Component Scores }\end{array}$ & 107 & 281 & 64 & 47 & 32 \\
1st Component Score & -0.61 & -0.53 & 0.93 & 1.20 & 3.07 \\
2nd Component Score & -0.95 & 0.49 & -0.50 & -1.30 & 1.75 \\
3rd Component Score & 1.36 & -0.27 & -1.46 & -0.55 & 1.52 \\
4th Component Score & -0.47 & 0.21 & -1.47 & 1.75 & 0.08 \\
Average of Irrigated Area, \% & 72.1 & 49.5 & 60.5 & 67.3 & 74.8 \\
Composition by Water Source, $\%$ & & & & \\
CNL & $70.6^{*}$ & 13.3 & 12.9 & 8.2 & 14.3 \\
TWwoE & 12.8 & $53.5^{*}$ & $33.4^{*}$ & 8.6 & 13.6 \\
WLwoE & 2.4 & 6.3 & 5.4 & $13.1^{*}$ & 18.9 \\
RIV & 2.4 & 4.4 & $19.3^{*}$ & $7.0^{*}$ & 4.1 \\
TWwE & 2.4 & 4.9 & 4.4 & 1.0 & $18.0^{*}$ \\
TNK & 1.3 & 2.6 & $12.8^{*}$ & 3.5 & 2.3 \\
WLwE & 1.3 & 1.3 & 1.7 & 1.5 & $14.9^{*}$ \\
OTH & 6.9 & 13.6 & $10.1^{*}$ & $57.2^{*}$ & $13.5^{*}$ \\
\hline
\end{tabular}

* Coefficient of variation smaller than 1.0.

with surface water, which might include the ahar-pyne system. The blocks classified as Class E depend on conventional irrigation powered by electricity, although such blocks are few.

Map 6.6 portrays the distribution of blocks classified as Class D. Of 47 blocks of the class, 14 blocks are concentrated in Gaya District and 10 blocks in 4 other districts along the foot of the southern hills, which suggests that ahar is especially characteristic of the southern piedmont area. Other blocks of Class D are found mainly in flooding areas along the Kosi River and the Gandak River.

Dikes of large ahars are drawn on the 1:50,000 topographic maps of the Survey of India, as shown in Map 6.1 with the case of Machala Ahar. Through interpretation of topographic maps published in the 1980 s and 1990s, locations of ahars are identifiable; they can be analyzed in a regional setting. The survey area extends from $24^{\circ} 30^{\prime} \mathrm{N}, 84^{\circ} 30^{\prime} \mathrm{E}$ to $25^{\circ} 15^{\prime} \mathrm{N}, 85^{\circ} 45^{\prime} \mathrm{E}$, as shown in Map 6.6. This area exceeds $8,000 \mathrm{~km}^{2}$, including large parts of Gaya, Nawada and Jehanabad Districts, the southern half of Nalanda District, and the eastern part of Aurangabad District. The whole area was divided into 130 grid squares of $5^{\prime} \times 5^{\prime}$, each of which covers about $78 \mathrm{~km}^{2}$. The total length of dikes was measured by grid for the whole area. This figure is regarded as representing the density of ahar in general. 


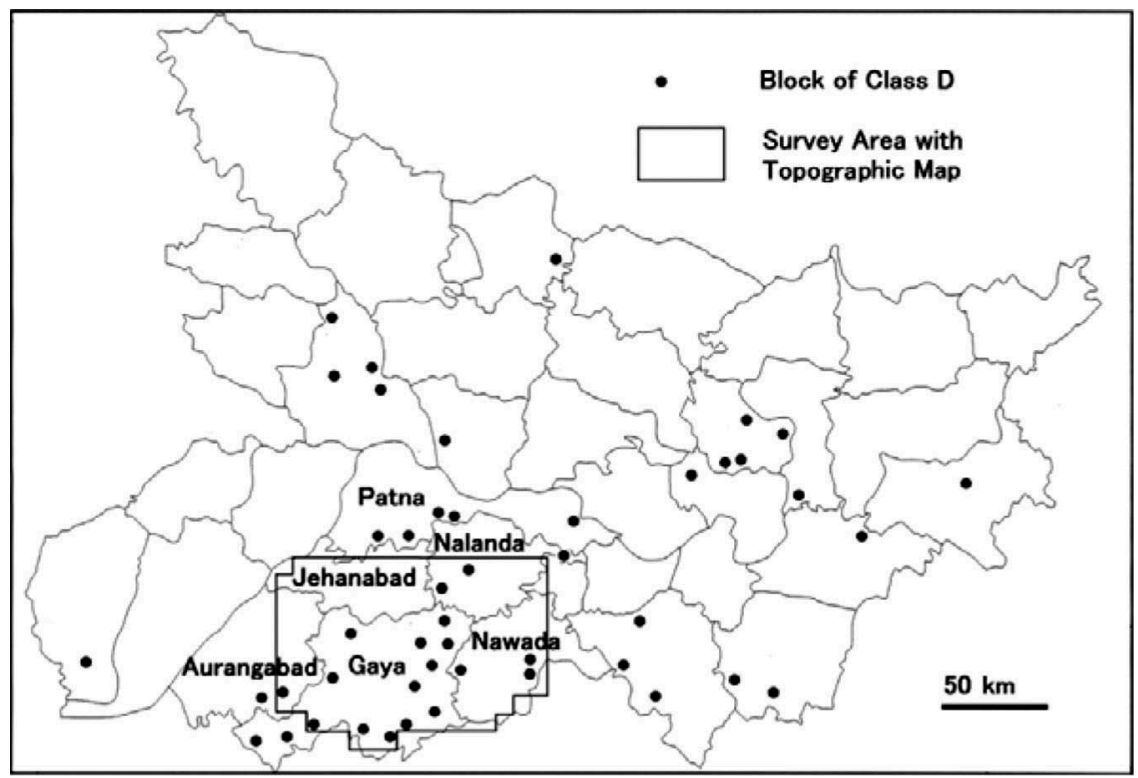

Map 6.6 Distribution of Blocks Classified as Class D

The results are presented in Map 6.7, which is overlaid with a satellite image of the survey area. It is clear that ahars are distributed more densely in the upper part of the southern Ganges alluvial plain at the foot of Hazaribagh Plateau, where the riverbeds of major tributaries are permeable. The river courses can be recognized as white lines that indicate sandy soils.

These data facilitate the estimation of water storage capacity of ahars in the survey area. Only the quantity of water reserved in the gutter is calculated here because conditions of standing water on the land inside the ahar differ among types and sizes. Based on the cross-section in Figure 6.1 and the author's survey of other ahars, the average gutter size is presumed to be $15 \mathrm{~m}$ wide $\times$ $2 \mathrm{~m}$ deep, which relies on the assumption that a gutter cross-section is about $30 \mathrm{~m}^{2}$. However, the total length of embankments in the survey area measures $3,374 \mathrm{~km}$ on the topographic maps. If considering the embankments which do not appear on the maps, the actual total length will be extended to $3,500 \mathrm{~km}$. Therefore, the water storage capacity of the ahars in the survey area can be estimated as 105 million $\mathrm{m}^{3}$, or at least 100 million tons of water.

\section{Discussion}

As final remarks, the importance and difficulties of ahar are discussed here. The importance of a large ahar-pyne system should be appreciated not only from a village-level local viewpoint but also from a broader regional 


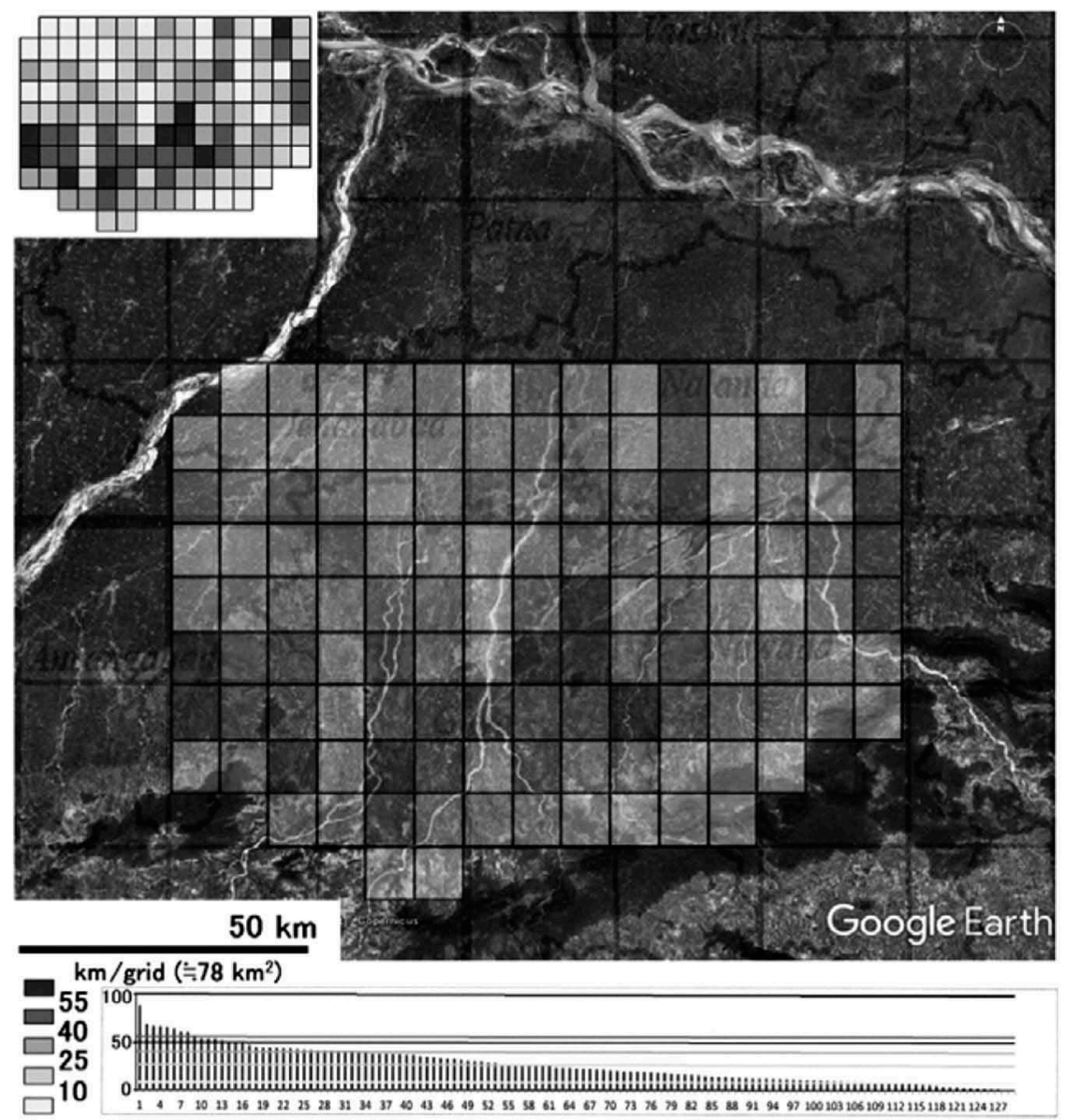

Map 6.7 Estimated Density of Ahar by 5'-by-5' Grid

perspective. For instance, to evaluate the contribution of irrigation water from ahar, aside from its direct beneficiary area, it is necessary in the first step to demarcate the entire downstream area, including the fields under plot-to-plot irrigation and rainfed ahars which collect the water from the main ahar-pyne system. In short, a large ahar-pyne system can be regarded as a node of a regional drainage network, or a focal point for regional resource management of surface water outside the large-scale irrigation scheme area.

The maintenance of embankments might not entail much difficulty because of their noticeable benefits for local farming. However, maintaining the canals, or the frame of network, in good condition will be more difficult 


\section{Tetsuo Satoh}

because of the lack of an overall administrative system to oversee the whole network. In addition to the financial problems for major maintenance works, complicated difficulties of water resource allocation are likely to exist. It must be a critically important challenge to provide a negotiation platform for the solution of water conflict. Moreover, the increasing number of embankment construction for highways and railways might affect the regional drainage system. Although quantitative estimation of such effects is difficult, it is necessary to consider it when planning water resource management for this region.

In the case of rainfed ahars, unstable water supply conditions constitute a fundamental shortcoming. Undependable availability of water will engender underestimation of the importance of ahar in this era of rapid development. In this regard, rainfed ahars around a large ahar-pyne system might be particularly beneficial because of their favorable locations. They are regarded as secondary nodes of regional drainage network. Therefore, their significance can be recognized easily. Considering that many rainfed ahars are located in the upper alluvial plain where farming conditions are unfavorable, it seems difficult to count on the role of ahars too much. In such areas, agricultural development itself might bring small benefits to the growth of rural economies. The villagers tend to depend more on outside non-agricultural activities than on local farming, which makes the maintenance of ahars more difficult using traditional communal systems such as collective work, i.e. goman.

However, rainfed ahars are expected to have some beneficial effects on local farming conditions. First, they facilitate the cultivation of early rabi crops, or so-called 'bonus' crops. Secondly, the water in ahar might recharge shallow aquifers, which can be exploited easily at low cost. Consequently, for the conservation of less-productive rainfed ahars, it will be practical to encourage the use of marginal labor such as that of women or elderly people. In this respect, NREGA programs and other subsidiary programs of village panchayat for major repairs seems appropriate. They are expected to be successful because they enable employment of local labor or heavy machines as necessary. Moreover, forest protection is important to conserve water resources in this region. The introduction of a participatory approach to the forest protection system is expected to be helpful to guarantee local farmers access to water source areas for better management.

\section{Notes}

1 The original data was integrated into block level data to avoid inaccuracy and lack of data. There were 532 blocks in Bihar State in 2011 and here the data of 531 blocks are analyzed.

2 Source: author's interview with villagers (16 August, 2016).

3 After measuring dissimilarity by squared standardized Euclidean distance, Ward method was adopted to make clusters. 


\section{References}

Fujita, K. (2014). "How Agriculture in Bihar Lagged Behind: Implications for Future Development," in Tsujita, Y. ed., Inclusive Growth and Development in India: Challenges for Underdeveloped Regions and the Underclass, London: Palgrave Macmillan, pp. $40-73$.

Fukuda, H. (1976). Irrigation in the World. Comparative Developments, Tokyo: University of Tokyo Press.

Koul, D. N., S. Singh, G. Neelam and G. Sukla (2012). "Traditional Water Management Systems: An Overview of Ahar-pyne System in South Bihar Plains of India and Need for Its Revival," Indian Journal of Traditional Knowledge, vol. 11 (2), pp. 266-72.

Pant, N. (1998). "Indigenous Irrigation in South Bihar: A Case of Congruence of Boundaries,” Economic and Political Weekly, vol. 33 (49), pp. 3132-38. 
$\because$ Taylor \& Francis

Taylor \& Francis Group

http://taylorandfrancis.com 


\section{Part II}

\section{Regional path dependencies and policy orientations for sustainability}


$\because$ Taylor \& Francis

Taylor \& Francis Group

http://taylorandfrancis.com 


\title{
7 Overview of the food-water-energy nexus in India and South Asia
}

\author{
Koichi Fujita
}

PROFESSOR AT THE CENTER FOR SOUTHEAST ASIAN STUDIES, KYOTO UNIVERSITY, JAPAN

\section{Atsushi Fukumi}

ASSOCIATE PROFESSOR AT THE SCHOOL OF ECONOMICS, UNIVERSITY OF HYOGO, JAPAN

\section{Introduction}

In India and throughout South Asia, three issues are closely interrelated: food production, water for irrigation (especially groundwater), and energy use. These issues are designated as the food-water-energy nexus. ${ }^{1}$ This chapter provides an overview of the issue, mainly by summarizing the statistical data and available information, and by reviewing the existing literature. The key is the special electricity tariff system called a flat tariff, which was widely adopted in India within a decade from the mid-1970s, because this triggered the emergence of the nexus. ${ }^{2}$ Because the tariff is fixed depending on a motor's horsepower without connection to the actual electricity consumption, the electric pump-set owners, who are farmers in most cases, have a strong incentive to use electricity excessively for lifting groundwater for irrigation, thereby jeopardizing the sustainable use of groundwater and ultimately sustainable food production itself. ${ }^{3}$

The introduction of a flat tariff did not necessarily provide pump-set owners with a power subsidy. However, given the rising political patronage in India since the late 1970s, the difference between the average cost of electricity supply and the collected charges from the agricultural sector (pumpset owners) has expanded, leading to large and constant commercial losses incurred by the State Electricity Boards (SEBs).

The commercial losses of SEBs had several negative consequences (Figure 7.1). First, the losses have been a major cause of chronic fiscal deficits of the state governments because they were obliged to make up for the SEBs' commercial losses. Second, the losses have severely limited the capacity of SEBs to invest in new power plants and even to maintain transmission and distribution lines, which has had economy-wide ill effects. A series of acute problems in the power sector of India such as the chronic power shortage, low quality of power supply (as exemplified by frequent power outages and interruptions, fluctuating voltage, and so on), and huge transmission and distribution (T\&D) losses (Figure 7.2), ${ }^{4}$ have been rooted in consistent annual losses incurred by SEBs. The flat tariff has also contributed to the loosening 


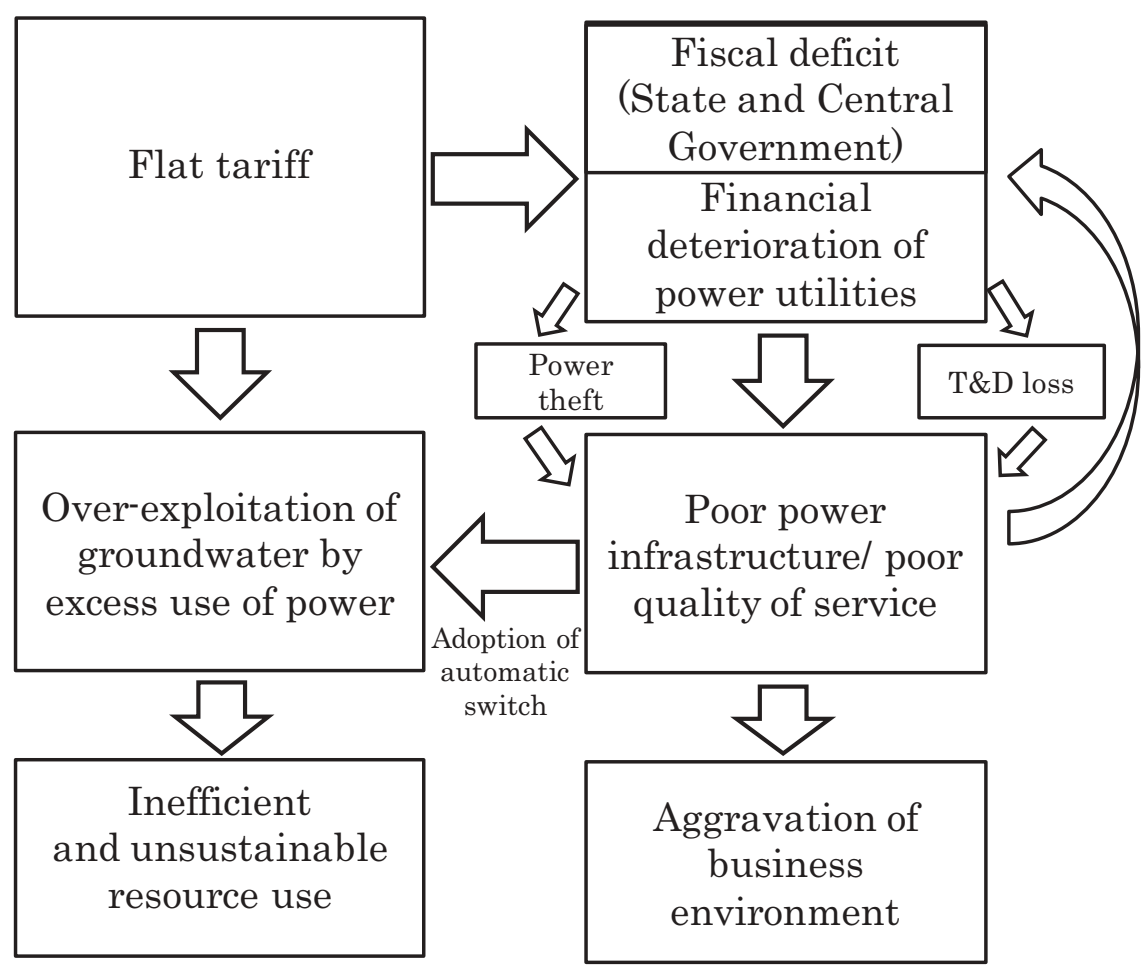

Figure 7.1 Effects of Tariff Policy on Indian Power Sector Source: Authors.

of the financial discipline of SEBs. Under circumstances in which electricity consumption by agricultural sector cannot be measured directly, SEBs had incentives to conceal their management inefficiency and to over-report agricultural power subsidies to state governments to obtain more financial assistance. Third, it slowed the pace of electrification, especially in remote rural areas. Even in rural areas already served by electricity, to restrict overall electricity consumption by the agricultural sector, SEBs often had to set a strict limit in allowing new line connections, thereby engendering inequality among the pump-set owners.

The composition of the chapter is described below. Section 2 presents a review of how the nexus issue emerged in India within a decade following the mid-1970s and then deepened thereafter, including government policies and reactions of various stakeholders to the policies. The regional divide of the nexus is given special attention here. In section 3, mainly based on a report by Shah (2009), issues related to groundwater irrigation in India are reviewed, with specific reference to (1) aquifers and groundwater use 


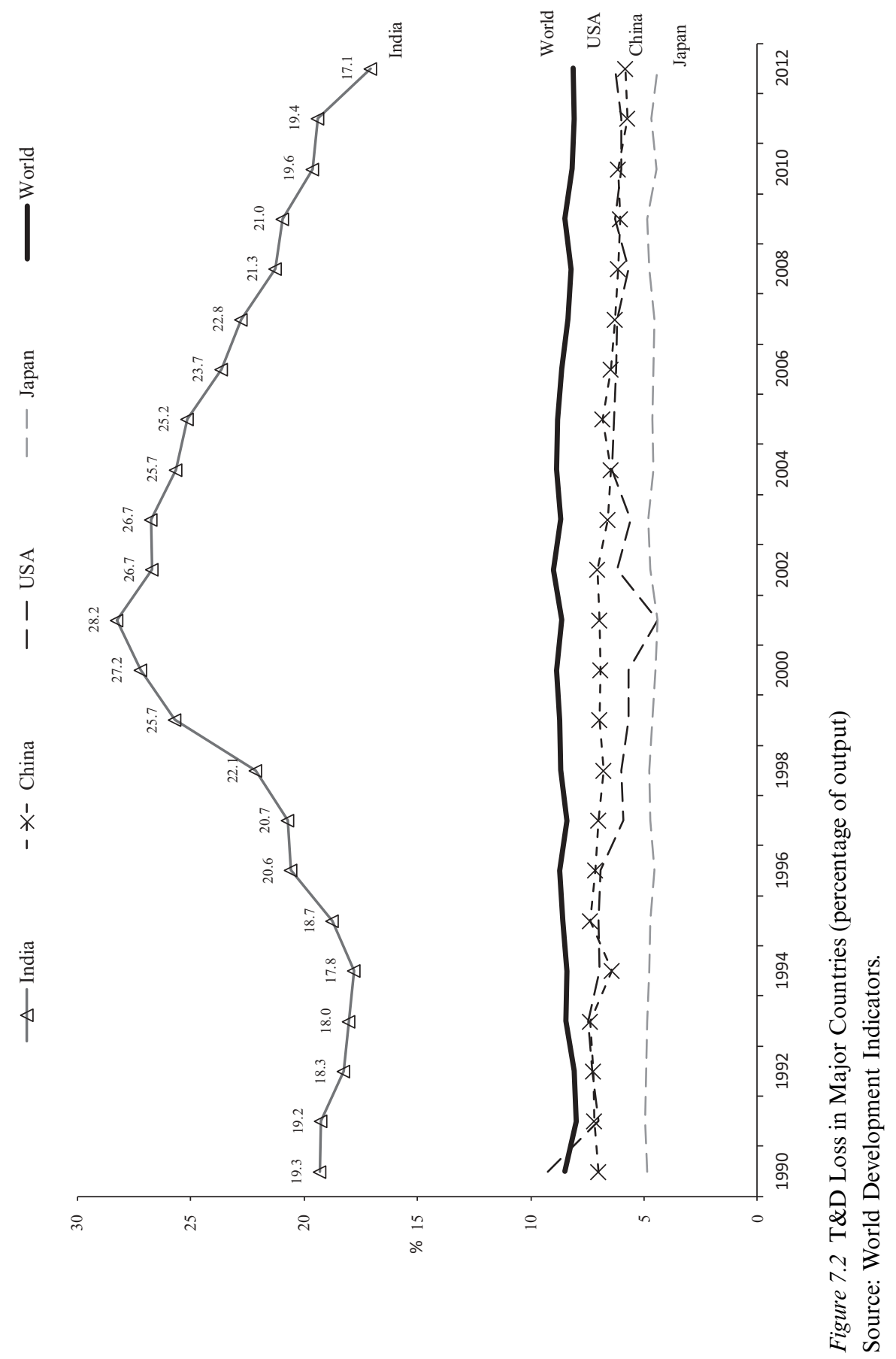




\section{Koichi Fujita and Atsushi Fukumi}

and (2) pump irrigation service markets. In section 4, again mainly based on work reported by Shah (2009), policies for combating the nexus are discussed briefly. Finally, in section 5, after briefly summarizing the chapter, the agenda for future research is discussed.

\section{Emergence and deepening of the food-water-energy nexus}

\subsection{Emergence of the nexus}

The food-water-energy nexus in India emerged from the mid-1970s to mid1980s when a flat tariff was introduced for electric pump-sets. Originally, the electricity consumed by pump-sets was metered. Farmers paid accordingly. However, mainly because of the incremented wage salaries paid to meter readers, the state governments introduced the flat tariff to save wage bills. Tushaar Shah, in the case of Uttar Pradesh, presents the following description:

The meter readers who were initially appointed on contract during the early 1960s soon unionized and eventually forced a populist Chief Minister to regularize them as government employees with manifold increases in wages and benefits. Soon thereafter, the quality of meter reading declined, and so did the collection of electricity charges. It was easy to bribe or browbeat meter readers into underreporting the consumption or tampering with the meter; moreover, to beat metering, farmers began to pilfer power by hooking directly to power lines since there was little to deter them.

(Shah, 2001: 18)

He continued with the following explanation:

(A)round then, a 1973 survey by the Rural Electrification Corporation encompassing several States found that the cost of metering electricity consumption ${ }^{5}$ by farmers and rural households was over $40 \%$ of the cost of the power itself! Uttar Pradesh (UP) was not the only State that was facing these problems; all States did. So in 1975, when SEB decided to get rid of metering of rural household and farm users, and switch to a flat monthly tariff unlinked to actual consumption, many other State governments were watching the implications with great interest; and in the following five years, most other Indian SEBs followed suit and changed from a metered to a flat electricity tariff, especially for agricultural users. 
In Karnataka, for instance,

(U)ntil 1981, irrigation pumps were metered and farmers paid electricity fairly regularly. In 1981, what later proved to be a disastrous precedent, all irrigation sets were de-metered. It was decided to charge farmers a flat electricity tariff on the ground that costs of reading meters, preparing bills and collection were higher than the revenues so generated.

(Mukherji, 2017) ${ }^{7}$

However, it is noteworthy here that the decision to convert from a metered to a flat electricity tariff was not made on the basis of such financial considerations alone. Soon after the decision made by the UP state government to convert to a flat tariff in 1975, politicians, especially in the southern states of India, started to make use of it as a political tool. According to Dubash and Rajan, 'the first use of electricity subsidy as a political tool may have occurred during the 1977 elections, when Congress-led southern state of Andhra Pradesh offered flat-rate tariffs to farmers as an election promise to help Congress get re-elected.' Then,

this may have a demonstration effect for the neighboring state of Tamil Nadu, where a new non-Congress Party (the ADMK) that had just come into power in a fragile four-way election, decided to offer free electricity to some groups of farmers.

Subsequently, political leaders in Maharashtra, Karnataka and elsewhere began to view the entitlement per se as a remarkably effective political device, in part because of the growing political power of backward rural communities and a rise of middle-class farmers' movement.

(Dubash and Rajan, 2001: 3369)

In summary, the flat tariff was introduced at first to save wage outlays for meter readers in some states, but the practice soon spread to other states, encouraged strongly by political factors, under circumstances in which Indian politics shifted from a Congress-dominant to a multi-party system from the late 1970s. Many parties, including the Congress, regarded the issue of power subsidy as 'a remarkably effective political device.' Through competition among the political parties, the flat tariff became popular

nationwide. The tariff de-linked from actual consumption of electricity thereby induced the emergence of the food-water-energy nexus in India. All serious issues affecting these sectors in India that other countries have rarely experienced derive from the special policies explained above.

\subsection{Deepening process of the nexus}

Figure 7.3 presents the electric pump-set growth process in India since 1974-75. Table 7.1 shows regional data. We classified the country into five regions: South, West, North, Central, and East. 


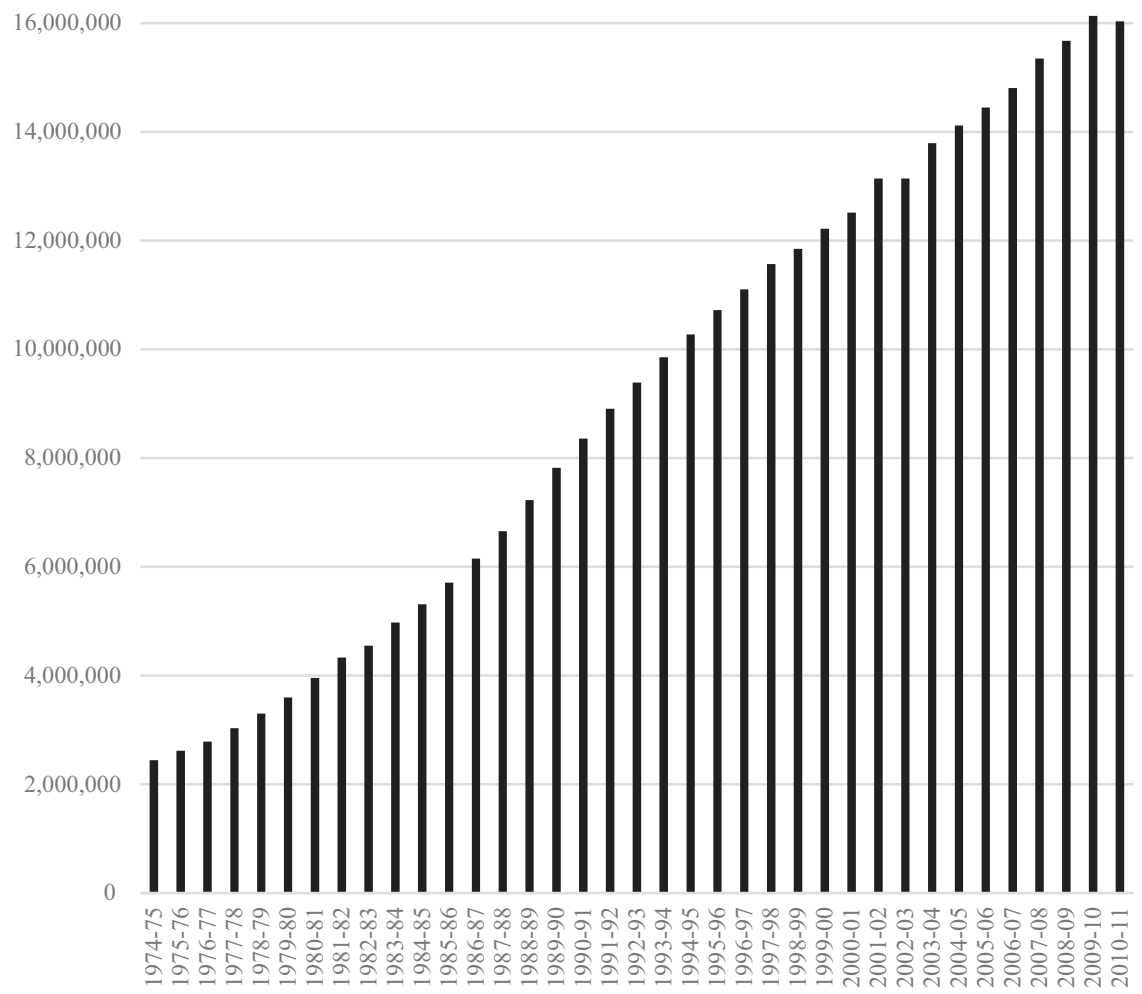

Figure 7.3 Number of Electric Pumpsets in India

Source: EPW Research Foundation (www.epwrfits.in/).

The number of electric pump-sets increased steadily from 2.5 million in the mid-1970s to 16 million in the early 2010s, with an average growth rate of 5.4 percent per year. In the early years of electric pump-set proliferation, as Shah put it, 'in Indian states like Punjab and Uttar Pradesh, chief ministers gave steep targets to district-level officers to "sell" electricity connections to farmers, and loans and concessions were made available.' 'By the mid-1970s, however, the enthusiasm of electricity utilities toward agricultural consumers had begun to dampen' (Shah, 2009: 142). The problem of incrementing wage bills described above turned the government quickly from encouragement to discouragement after the mid-1970s. It is noteworthy, however, that the Green Revolution started in East India only after the 1980s and that the 'enthusiasm of electricity utilities toward agricultural consumers' continued there 


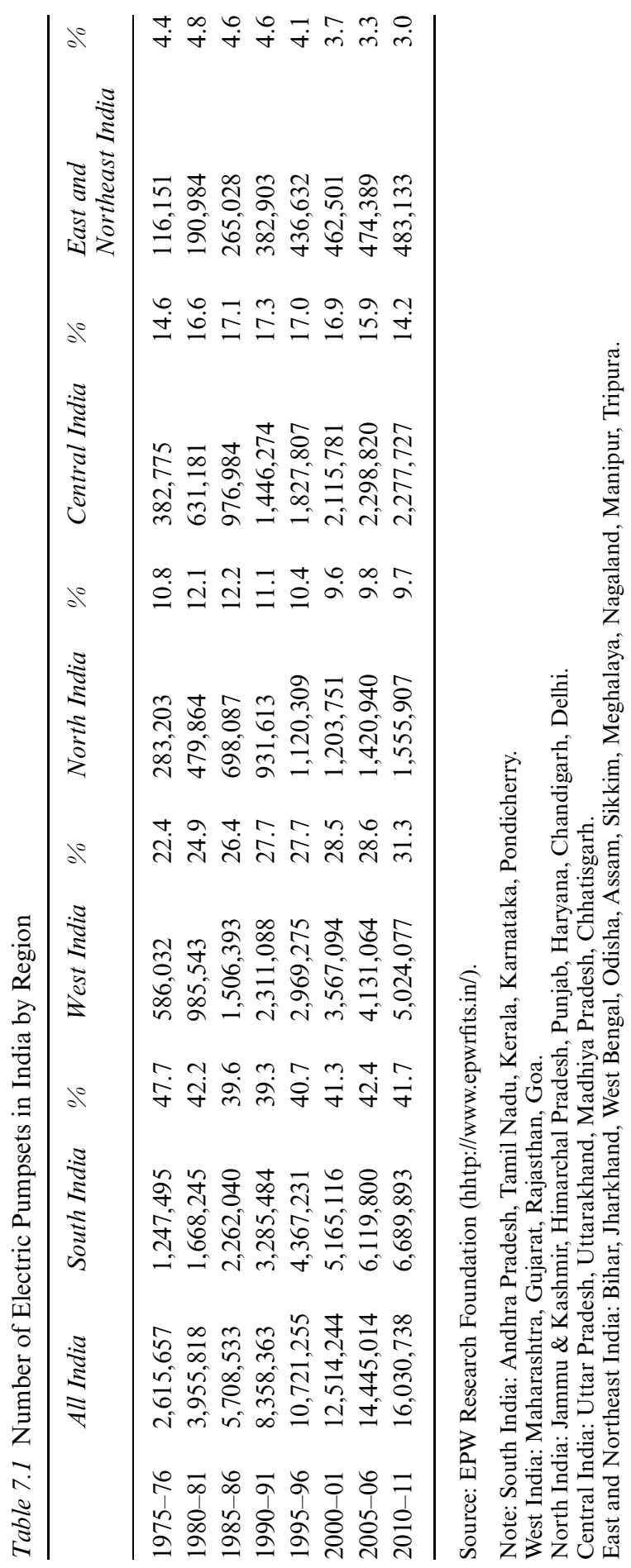


until the end of the 1980s. The entire period after the emergence of the nexus to the present day is therefore classified into three periods: (1) from the mid1970s to the end of the 1980s, (2) the decade of the 1990s, and (3) from 2000 to the present day.

A closer examination of the regional data of electric pump-sets in Table 7.1 reveals that after approximately 1990 the number of electric pump-sets began stagnating in East India. The trend has never reversed. Another notable fact is that in North India as well, the number of electric pump-sets remained largely stagnant throughout the 1990s, although after around 2000 it again started growing. The other important finding from the table is that, already in the mid-1970s, the pump-sets were highly concentrated in two regions: South and West India. The high percentage of the two regions (around 70 percent) has remained almost unchanged. By sharp contrast, the share of East India remained very small: it even declined from $4-5$ percent to 3 percent. The other two regions of North and Central India share the remaining 25 percent.

To elucidate the food-water-energy nexus in India more deeply, the number of diesel pump-sets must be examined (Table 7.2). Diesel pump-sets are divided into 'wells (dug-wells) with diesel pump-sets' and 'diesel tube wells. ${ }^{8}$ Using the same statistics (Agricultural Census) the electric pump-sets are also divided similarly (Table 7.3). For unknown reasons, the statistical figures presented in Tables 7.1 and 7.3 differ greatly. Especially notable are the following two: (1) In Central India, the number of electric pump-sets stagnated completely from 1990-91 to 2000-01 in Table 7.3, although it increased considerably in Table 7.1. (2) East India showed a three-fold increase in electric pump-sets during the two decades, as shown in Table 7.3, although that growth largely stagnated during the same period in Table 7.1.

Putting statistical inconsistencies aside, the major findings from Tables 7.2, 7.3, and 7.4 can be summarized as described below. First, the electrification rate of pump-sets in south India, already very high at 83.6 percent in 1990-91, progressed further and reached 95 percent by the early 2000s. That is a remarkable achievement considering that the number of pump-sets continued to increase rapidly in south India. Second, the same rate was also already high in west and north India between 60-65 percent in 1990-91. Both regions achieved more than 80 percent by $2010-11$, although the period of electrification progress differed during the 1990s in west India vis-à-vis the 2000s in north India. Third, the electrification rate in central India revealed that growth in the number of electric pump-sets had stagnated completely during the 1990s and 2000s, whereas diesel pump-sets once increased from 14,000 in 1990-91 to 18,301 in $2000-01$, but then declined sharply to 6,181 in $2010-11$. Fourth, the rate in East India remained extremely low at less than 20 percent. It is noteworthy that the higher percentage of 28.8 percent in 2000-01 is affected by the lack of data in Bihar and Jharkhand in that year. Nevertheless, the progress of electrification of 'wells with pump-sets' during the 2000s is notable. The increase of diesel pump-sets after 1990 is remarkable in this region, ${ }^{9,10}$ which is a sharp contrast with central India. 


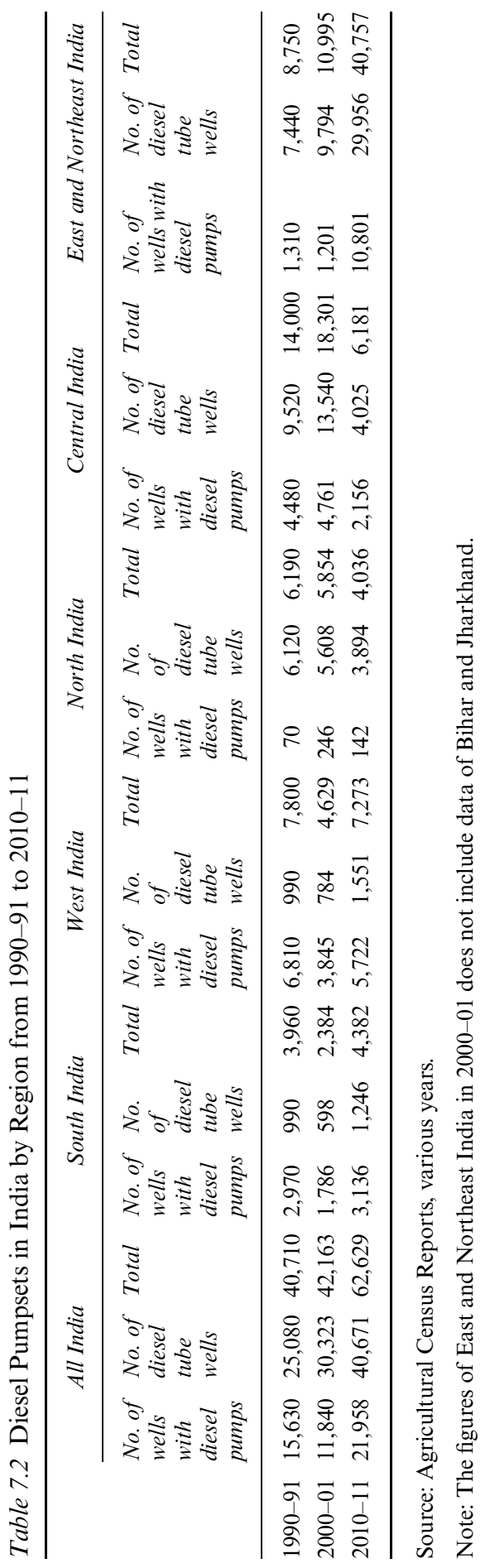




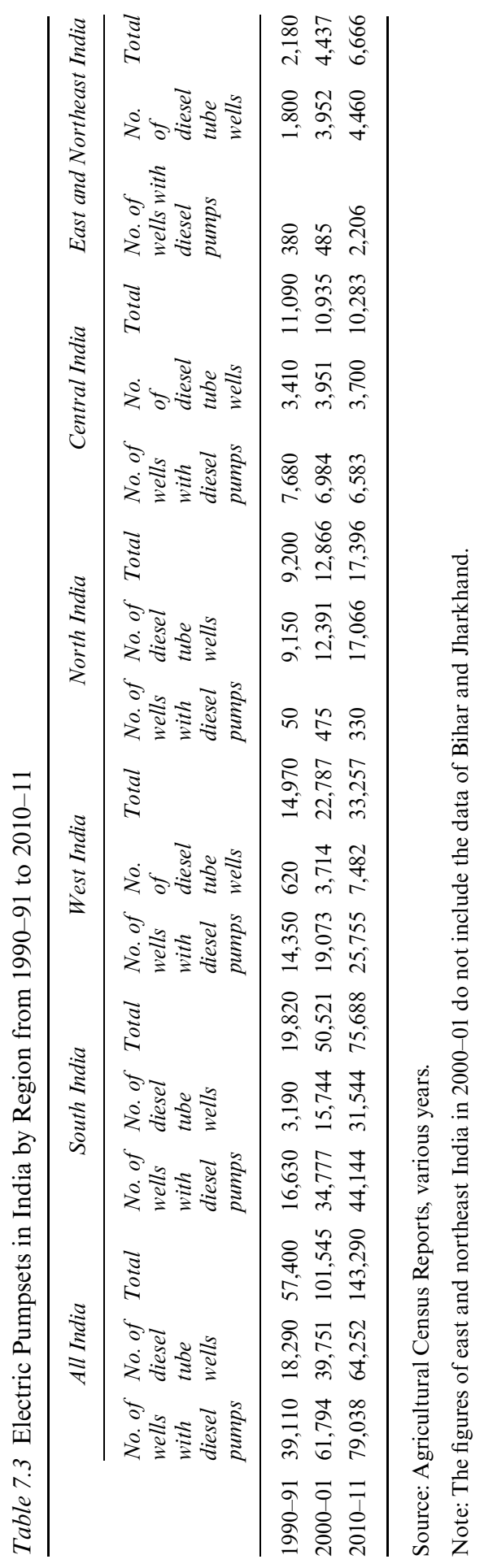


Table 7.4 Share of Electric Pumpsets (wells + tube wells)

\begin{tabular}{lllllll}
\hline All India & $\begin{array}{l}\text { South } \\
\text { India }\end{array}$ & $\begin{array}{l}\text { West } \\
\text { India }\end{array}$ & $\begin{array}{l}\text { North } \\
\text { India }\end{array}$ & $\begin{array}{l}\text { Central } \\
\text { India }\end{array}$ & $\begin{array}{l}\text { East and } \\
\text { Northeast } \\
\text { India }\end{array}$ \\
\hline $1990-91$ & 58.5 & 83.6 & 65.7 & 59.8 & 44.2 & 19.9 \\
$2000-01$ & 70.7 & 95.5 & 83.1 & 68.7 & 37.8 & 28.8 \\
$2020-11$ & 69.6 & 94.5 & 82.1 & 81.2 & 62.5 & 14.1 \\
\hline
\end{tabular}

Source: Prepared from Tables 7.2 and 7.3.

Note: The figures of East and Northeast India in 2000-01 do not include the data of Bihar and Jharkhand.

Shah, Singh, and Mukherji (2006), based on data collected in 2002 from 2,629 well owners from 278 villages in India, Pakistan, Nepal Terai and Bangladesh through the International Water Management Institute's IWMITata Water Policy Research Program, classified the Indian subcontinent into three groups as follows.

1) Group I (Pakistan Punjab \& Sind + Bangladesh)

Regions with metered agricultural electricity supply and little or no subsidy benefit.

2) Group II (eastern India + Nepal Terai) ${ }^{11}$

Regions where the electricity supply to agriculture is heavily subsidized in nominal terms, but the electricity supply and infrastructure have deteriorated greatly, resulting in little or no subsidy.

3) Group III (all regions of India except eastern India + Pakistan NWFP)

Represents vast areas of western and southern India where electricity subsidy to groundwater irrigation is real and substantial.

In this wider regional context of the Indian subcontinent, east India in our regional category is classified in Group II, whereas the other four regions (South, West, North and Central India) are classified in Group III. Such a regional structure in terms of significance of agricultural electricity use is reflected in the power subsidies provided by the state governments (Figure 7.4). As the figure shows, except for east India, all regions have suffered the burdens of the agricultural power subsidy. In the four regions other than east India, the percentage of agricultural power subsidy jumped from 15-20 percent to $30-65$ percent of gross fiscal deficits of the state governments after the mid1980s. Table 7.5 presents the same percentages in major individual states.

Efforts to tackle problems of the power sector in India began with measures promoting the entry of non-governmental independent power producers (IPPs) in the early 1990s. However, the policy target gradually shifted to financial 


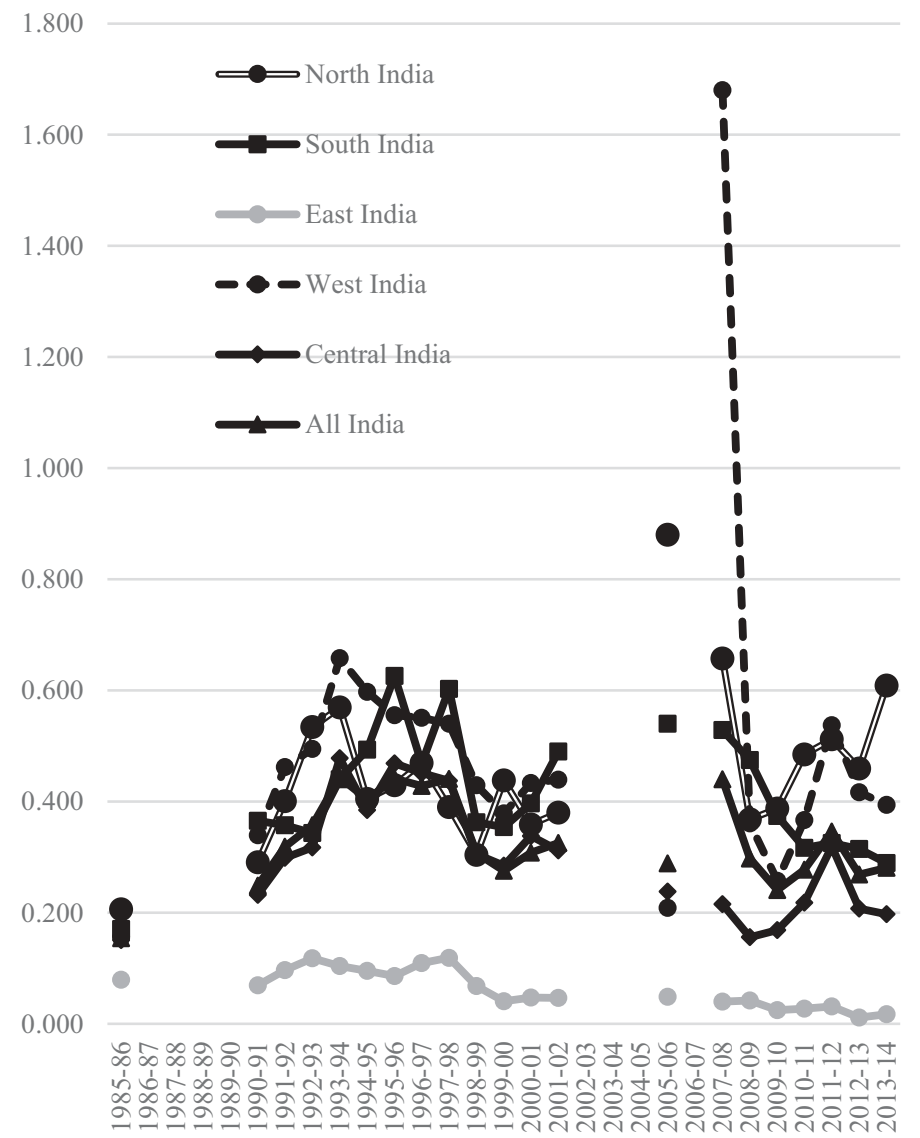

Figure 7.4 Percentage of Agricultural Electricity Subsidy in Gross Fiscal Deficits of State Governments

Source: Data for agricultural power subsidies were obtained from Planning Commission (1986, 1992, 2002, 2011, and 2013), except 2005, as obtained from Power Finance Corporation Limited (2008).

Data on gross fiscal deficits was obtained from EPW Research Foundation (www. epwrfits.in/).

reconstruction because it became apparent that almost all power supply difficulties stem from the tight financial status of the state power utilities, especially in the distribution sector. Among various measures taken in the reform process, a crucially important one was the unbundling of SEBs into generation, transmission, and distribution corporations following the single-buyer model started in developed countries. In India, the primary objective was to commercialize the power sector and to make contributions of individual companies to overall commercial loss and profit more transparent, thereby improving the management efficiency of the power utilities. 


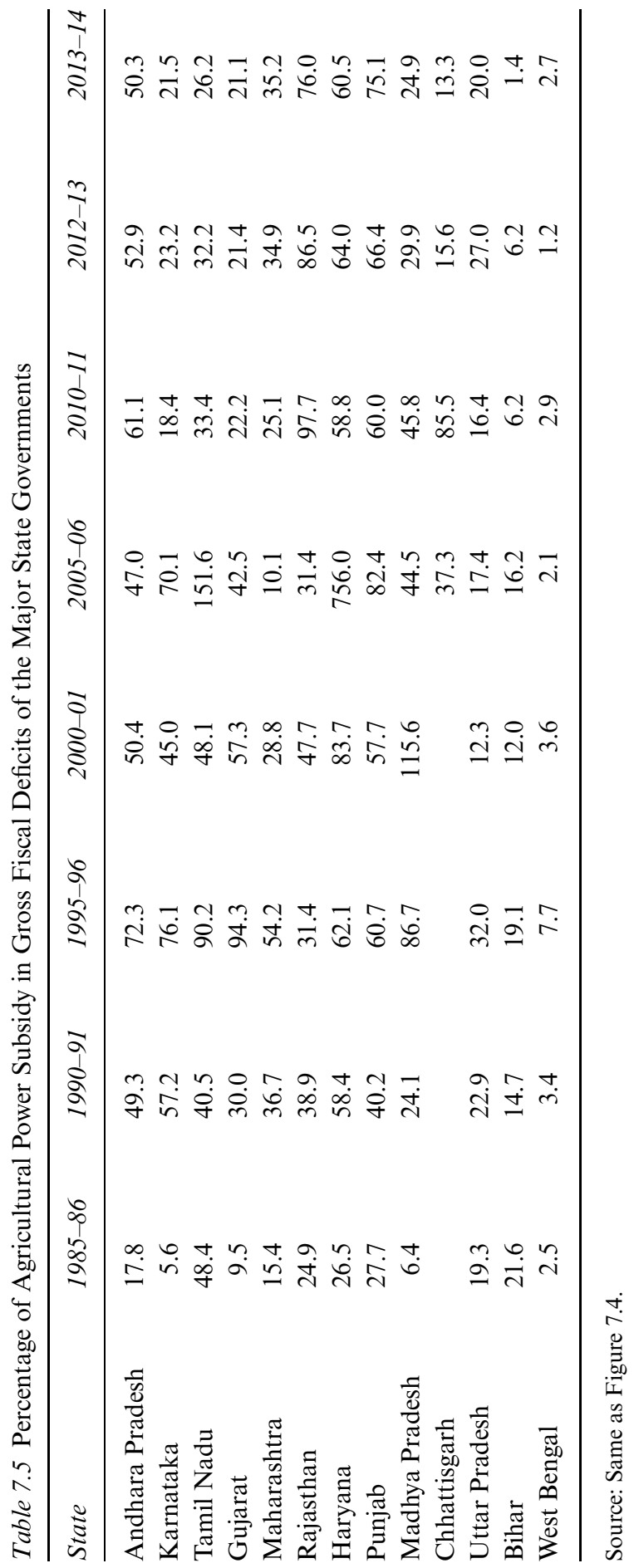


The establishment of the State Electricity Regulatory Commission (SERC) in each state was another important pillar of the power sector reform. Although SERCs served various functions such as the issuance of licenses for distribution and intrastate transmission, and assurance of nondiscriminatory open access, ${ }^{12}$ their main function was in setting tariffs. The SERCs were expected to promote the rationalization of a tariff structure for financial reconstruction of power utilities while considering the protection of consumers and the quality of service. For this purpose, isolation from political intervention was a vital element to create a commission with the authority to decide tariffs independently. The Electricity Act 2003 repealed all existing electricity laws and made these measures compulsory in a time-bound manner, which was thereby expected to accelerate the reform process. ${ }^{13}$

As Figure 7.4 shows, the percentage of agricultural power subsidy in gross fiscal deficits of the state governments declined from the late 1990s. Such an improvement is apparently an outcome of the power sector reforms. Figures 7.5 and 7.6 show changes in the tariff rate (nominal) by sector in comparison with the unit cost of electricity supply. Results show that the unit cost of electricity, albeit nominal terms, has been climbing year by year, reaching nearly Rs.6/kWh in 2013 .

It is also clear that the tariff rate for agriculture (electric pump-sets) remained unchanged or even lower after the mid-1970s. Therefore, the recovery rate (percent of unit cost) fell below 10 percent by the end of the 1990s, but started to reverse after 2000, giving a somewhat improved recovery rate to around 30 percent in recent years. However, as Figure 7.7 shows, the agricultural loss remains a major cause of the commercial losses sustained within the power sector.

Given the current deteriorated financial status of the power sector described above, it would be difficult to conclude that the policy measures of unbundling of SEBs and establishing SERCs were successful. Based on case studies presented by Haryana and Odisha, Ruet (2005) pointed out that unbundling and corporatization failed to diminish the strong influence of state politics, but yielded only judicial changes. Similarly, doubt arises about the functions and independence of SERCs: in spite of their strong power, regulators might be unwilling to exercise that power on an independent commission basis in practice because the rationalization of power tariff remains a sensitive issue. Dubash and Rao (2008) pointed out that electricity regulation was, in many ways, merely an extension of previously established utilities and the state electricity department both through the selection of regulators and the appointment of employees.

Figure 7.6 shows that the overall recovery rate remains at around 70-80 percent. Both the 'commercial light, heating and small power' and the 'industrial Low, Medium and High voltage' show charges in excess of the unit cost (cross subsidy). Another notable fact is that the percentage of the agricultural power subsidy in gross fiscal deficits of state governments did not 


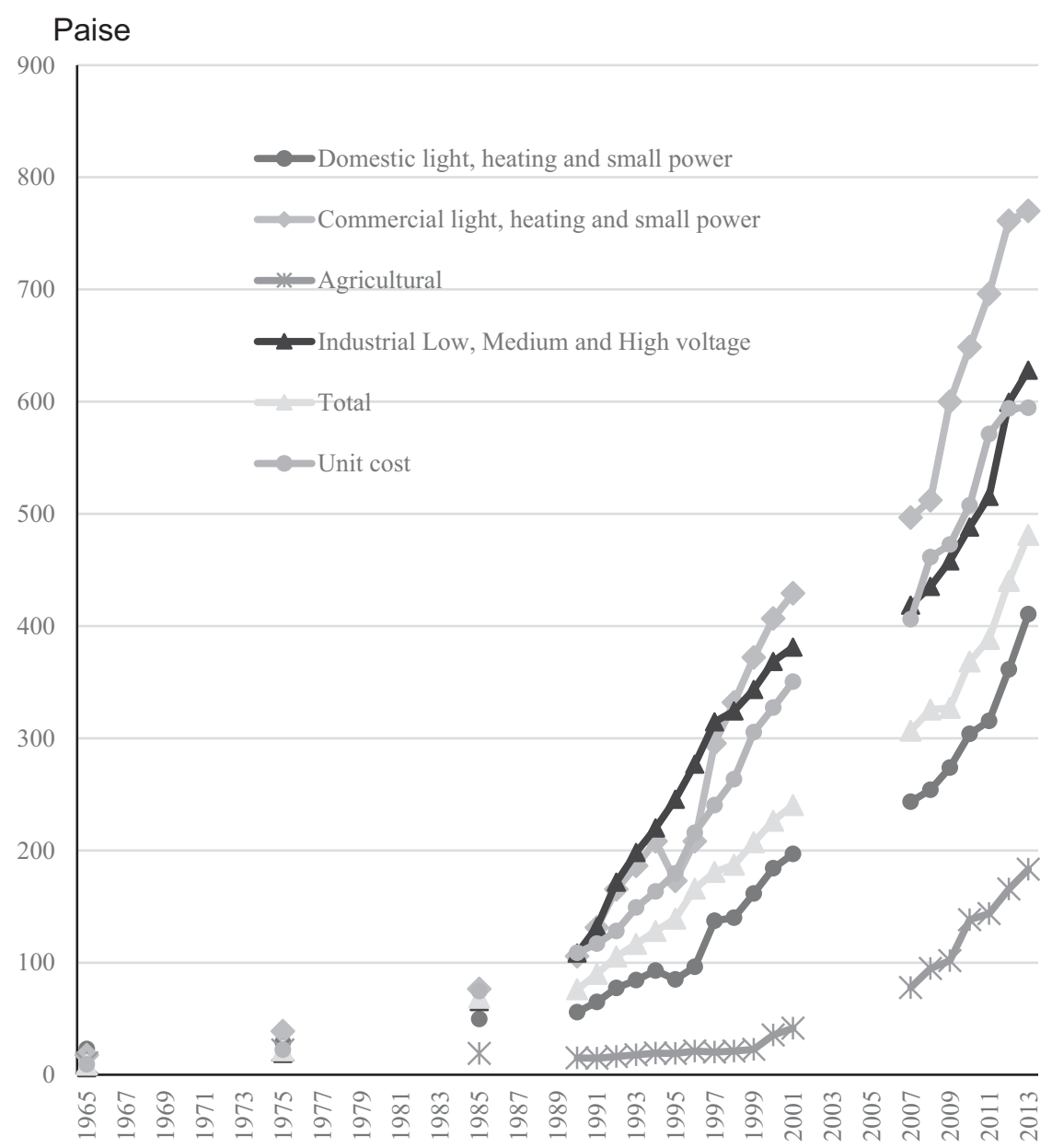

Figure 7.5 Unit Cost and Sector-wise Tariff Rate of Electricity Supply

Source: Planning Commission (1986, 1990, 1992, 2000, 2001, 2002, 2011, and 2013) except for 1965 and 1975, as obtained from Central Electricity Authority (1966, 1976).

decline in North India (Figure 7.4) ${ }^{14}$ and in Andhra Pradesh and Rajasthan (Table 7.3). It is noteworthy here that the agricultural tariff remained totally free in Punjab and Andhra Pradesh, as it was in Tamil Nadu.

Another important issue is that to control aggregate farm power consumption, SEBs began reducing daily hours of three-phase power supply while maintaining single-phase or two-phase power supply for the remainder of the day. The assumption was that irrigation pumps would be unable to 


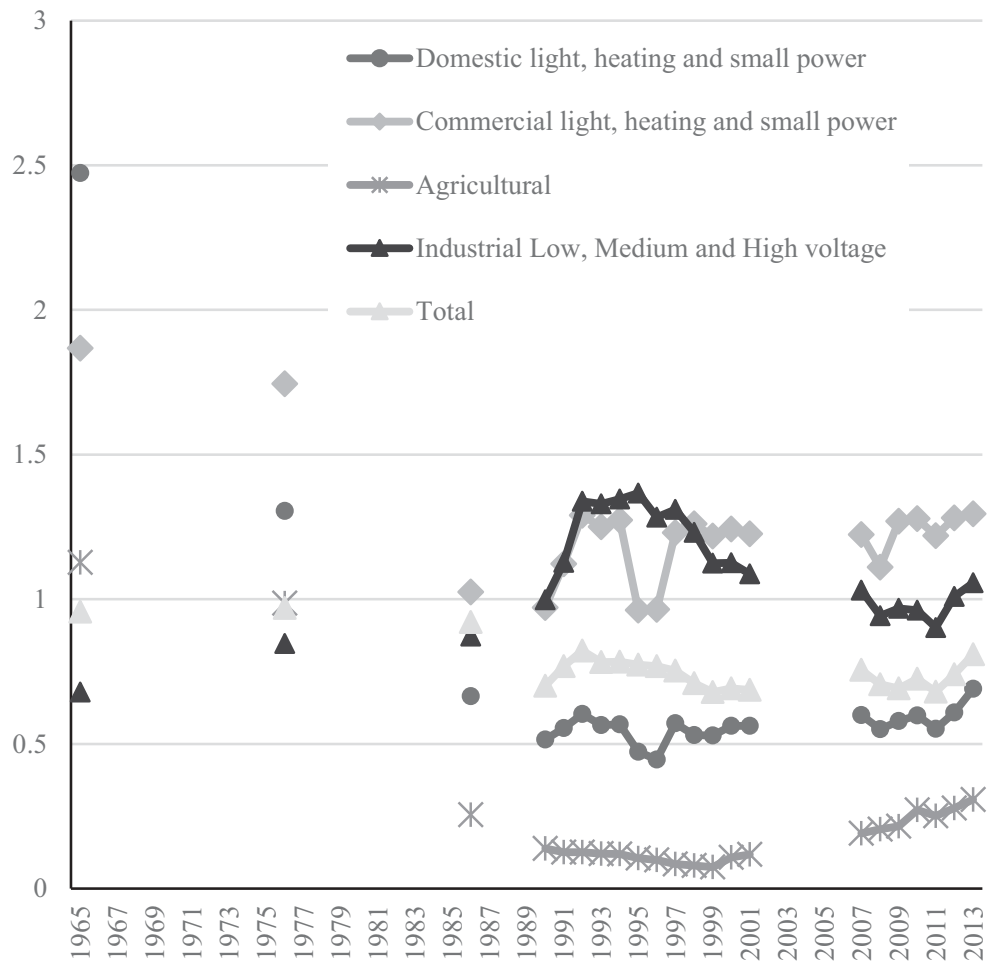

Figure 7.6 Sector-wise Recovery Rate of Electricity Supply

Source: Same as Figure 7.5.

operate on less than three-phase power supply, whereas domestic users can operate their appliances on single-phase or two-phase power. However, this had adverse effects on rural industries, commercial establishments, hospitals, schools, and other rural institutional customers that were dependent on a three-phase power supply (Shah, Giordano, and Mukherji, 2012: 999).

The last point that must be borne in mind is that many pump-set owners in India, although they are benefitted from the power subsidy, are not necessarily satisfied with the power supply quality. Studies showed that voltage fluctuations and frequent interruptions imposed high pump repair and maintenance costs on farmers (Shah, Giordano, and Mukherji, 2012: 999). Many observers argue that the power supplied to farmers is mostly off-peak and of poor quality, and that its opportunity cost is more like Rs.1.8-2/kWh vis-à-vis Rs.5/kWh (Shah, 2009: 258). It can be said that farmers are already paying the right price for electricity if that is a correct estimate (see Figure 7.5). 


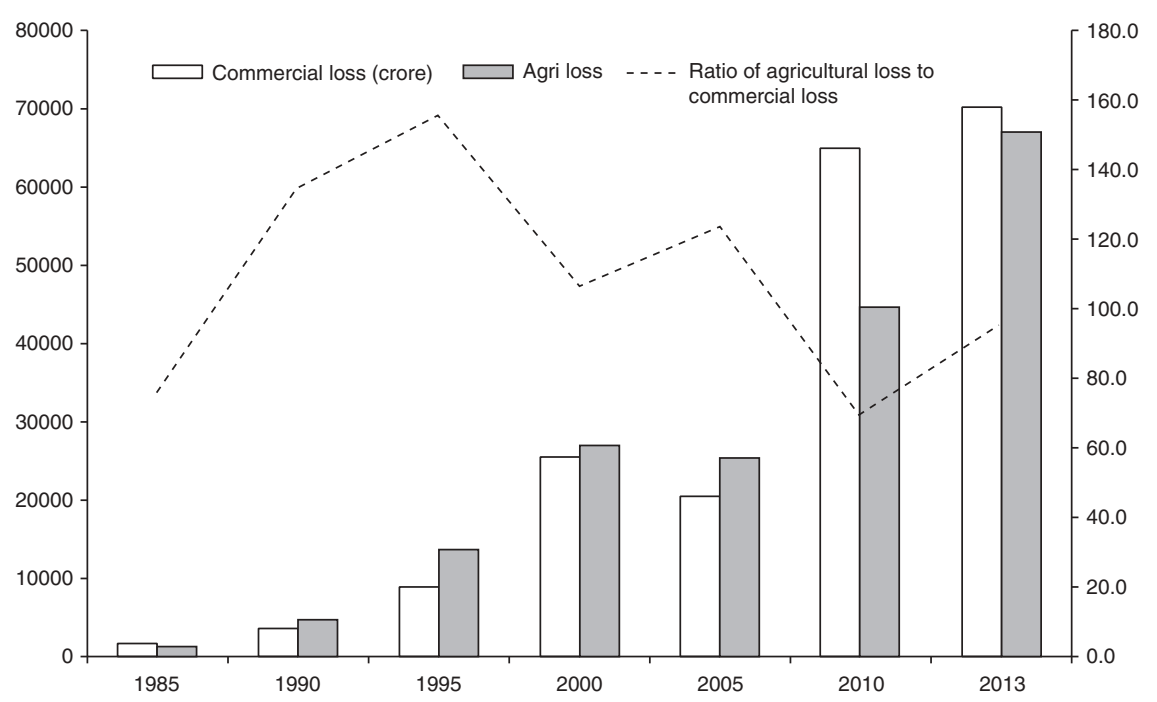

Figure 7.7 Commercial Loss and Agricultural Loss in Indian Power Sector

Source: Planning Commission (1986, 1992, 2002, 2011, and 2013), except for 2005, which were obtained from Power Finance Corporation (2008).

\section{Issues of groundwater irrigation}

\subsection{Aquifers and groundwater use}

Shah (2009) classified South Asia into four (five) major regions in terms of hydrogeological setting: major alluvial plains (arid and humid), coastal plains, intermountain valleys, and hard-rock areas. Moreover, Shah (2009) presented discussion of major difficulties and issues in each region related to groundwater utilization, including water quality for both irrigation and drinking purposes. His arguments can be summarized as presented below. ${ }^{15}$

\subsubsection{Major alluvial plains (Humid)}

The typical region is the eastern Ganga Basin, including the BrahmaputraMeghna Basin, endowed with alluvium to the depth of 600 meters, with annual flood discharge of more than 500 billion cubic meters, ${ }^{16}$ where intensive groundwater irrigation has not only delivered benefits to livelihood but which has also eased acute waterlogging and flooding. However, the region failed to use the potential benefits from extraction of plentiful groundwater. In Odisha, Bangladesh and Nepal Terai, governments have continued metering at commercial rates and have forced water extraction mechanism (WEM) ${ }^{17}$ owners to use diesel instead, thereby compelling a 'dieselization' of the pump irrigation 
economy. In West Bengal, Bihar, and eastern Uttar Pradesh, however, governments have achieved the same result by whittling down the effective supply of electricity to agriculture. Most farmers in these regions had the option of using diesel pumps, which are best for pumping from shallow depths. Arsenic contamination of groundwater, an important public health issue in Bangladesh, West Bengal, Nepal Terai, and parts of Bihar and eastern Uttar Pradesh, requires a strong response. Nevertheless, restricting pump irrigation is unlikely to eliminate arsenic from water supplies because it is geogenic.

\subsubsection{Major alluvial plains (Arid)}

The Indus Basin, a typical region under this category, has earned socioecological dividends from pump irrigation, although those returns are diminishing. Fifty years ago, many areas of Pakistan and India Punjab, Haryana, western Uttar Pradesh, North Rajasthan, and Sind confronted acute difficulties caused by waterlogging. The tube well program of the Salinity Control and Reclamation Project (SCARP) failed, but private pump irrigation performed better than SCARP, and on a much larger scale and with large socioecological dividends. Increasing salinity in groundwater is compelling farmers to husband their freshwater supplies from surface irrigation and saline groundwater better, thereby improving salt balances in their irrigation agriculture.

\subsubsection{Coastal plains}

In some coastal plains and arid alluvial plains, the governance challenge is coping with chronic salinization and depletion, which might preclude agriculture and even human settlement. In Pakistan, groundwater depletion is a daunting difficulty in Baluchistan, where the rate of extraction is far greater than the rate of recharge. In India, according to Kumar (2007), semiarid North Gujarat withdraws 17 percent more groundwater every year than the recharge. In Mehsana district, water tables are falling by $2-6$ meters per year. As a result, fluoride contamination of groundwater, the main source of drinking water, is leading to widespread incidence of dental and skeletal fluorosis, especially among poor people, whose diets are calcium-deficient.

\subsubsection{Hard-rock areas}

In hard-rock areas of peninsular India, initial electricity subsidies had created a pump irrigation economy addicted to cheap electricity. As the pumping depth increased to 20 meters or more, farmers became unable to rely on centrifugal diesel pumps. They were forced to switch to electric pumps. Metering tube wells and charging pump irrigators to reflect the true cost of supplying electricity would make irrigated agriculture completely unviable. ${ }^{18}$ Restricting the power supply to cut electricity boards' losses would mean closing down the pump irrigation economy because switching to diesel pumps is no longer 
feasible in many areas. The overexploitation of groundwater has also contributed to the growing concentration of fluoride and other salts in groundwater, the main source of drinking water for rural as well as urban populations.

In summary, the food-water-energy nexus in India is a crucially important issue mainly in the western half of the country. In such areas under an arid or semi-arid climate, a highly contradictory situation prevails in which groundwater has been excessively pumped, causing severe issues of groundwater depletion and contamination on one hand, and bankruptcy of the power sector on the other hand. By contrast, in the more humid regions of the eastern half of the country (including Bangladesh and Nepal Terai) with ample rainfall and abundant aquifers, groundwater development has been by and large restricted by 'dieselization.' Therefore, the opportunity of groundwater-led growth and poverty alleviation has been frustrated despite high expectations (Kahnert and Levine, 1993). ${ }^{19}$ The major cause of the SEBs' commercial loss in the latter regions was not power subsidies given to agriculture. Inefficient management, including huge T\&D losses, power theft, and widespread corruption, has been the major cause. Because of such management inefficiency, the progressive use of electric pump-sets has almost stopped since the early 1990s, as described earlier. $^{20}$

\subsection{Pump irrigation service markets ${ }^{21}$}

In South Asia, vibrant and pervasive water markets have emerged as a growth industry. Hence, WEM ownership is no indicator of pump irrigation penetration. Irrigation service markets that emerged in Gujarat around 1910 quickly became sophisticated economic institutions that encouraged a class of pumping irrigation 'entrepreneurs,' who invested in heavy-duty WEMs and extensive buried pipeline networks expressly to sell pump irrigation to a client base for profit.

Because they spread across regions, pump irrigation markets became a common decentralized institutional arrangement that is unique to South Asia (Shah, 2009: 95-96). An exception is recent hard-rock peninsular India, where pump irrigation markets have become thin and shallow, with owners of wells barely managing to meet their own supplemental irrigation needs (ibid: 100).

In earlier days, because of the high pricing of irrigation services by 'monopolistic' pump-set owners, some scholars have expressed anxiety related to the unequal distribution of benefits from irrigated agriculture through irrigation service markets. Subsequent research, however, has revealed that, with some exceptions, the spread of pump irrigation markets has had large-scale and beneficial equity effects by spreading irrigation among smallholders. ${ }^{22} \mathrm{We}$ also found the same tendency of equalization that progressed in northwest Bangladesh during the 1990s (Fujita, 2010: Chapter 3).

However, after the turn of the century, the situation started to reverse, especially in East India where dependence on diesel pump-sets is high. ${ }^{23}$ Aditi Mukherji pointed out that the retail price of diesel fuel in Kolkata, 
around Rs.5/liter in 1990, started to rise gradually to Rs.10 by the end of the 1990s. Subsequently, it climbed rapidly to nearly Rs.30 in 2005 (Mukherji, 2007: 6420). Shah also reported that in Mirzapur, Uttar Pradesh, the relative price of one hour of diesel pump operation vis-à-vis rice (in terms of paddy) showed a sharp increase from $3 \mathrm{~kg}$ /hour in 1990 to $12 \mathrm{~kg}$ / hour by the mid-2000s (Shah, 2009: 267). As a result, irrigation service markets started to shrink and water charges began to surge more than the diesel prices (Mukherji, 2007; Shah, 2007, 2009). ${ }^{24}$

A hypothesis of ours is that more plentiful rainfall has apparently moderated the ill effects of the 'energy-squeeze' in West Bengal compared to the ill effects in Bihar and eastern Uttar Pradesh, and in Bangladesh relative to West Bengal. Central India (Uttar Pradesh, Uttarakhand, Madhya Pradesh, and Chhattisgarh) experienced a sharp decline in the number of diesel pump-sets after 2000, whereas East India achieved an increase during the same period, as described earlier, which can be attributed to such a difference in the climate condition. ${ }^{25}$

\section{Some policy issues}

Shah, Giordano, and Mukherji (2012) estimated the percentage of electricity cost (valued at US $\$ 0.08$ per $\mathrm{kWh}$ ) as a share of the gross value of agricultural output for the major 10 states of India. Results show 216.2 percent in Karnataka, followed in order by Gujarat (142.9 percent), Maharashtra (104.1 percent), Tamil Nadu (98.1 percent), Madhya Pradesh (96.4 percent), Andhra Pradesh (93.7 percent), Rajasthan (56.8 percent), Haryana (31.5 percent), Punjab (11.7 percent), and Uttar Pradesh (6.7 percent). They also estimated the likely effects of agricultural power subsidy termination for the major nine states (except for Uttar Pradesh) after 3-5 years at the all-India level. The major short-term results are described below.

1) Electricity use for groundwater extraction in the nine key states is expected to decrease from a maximum 78 billion $\mathrm{kWh}$ to a maximum 15-25 billion $\mathrm{kWh}$.

2) The gross irrigated area receiving full or supplementary irrigation from all sources is expected to decrease from 45 million ha to $20-25$ million ha.

3) Food-grain production is expected to decrease from 220 million metric tons to $140-170$ million metric tons.

4) The water buyers' area irrigated by electric pumpsets is expected to decrease from 6-8 million ha to 2-3 million ha.

5) The crop share commanded by water-sellers is expected to increase from 10-15 percent to $25-33$ percent.

6) The number of groundwater-overexploited blocks is expected to decrease from a minimum of 1,610 to $80-100$.

In summary, in spite of crucially important positive effects such as the elimination of power subsidies and recovery of groundwater resources, several 
severe consequences will arise such as huge losses of food-grain production and loss of farmers' income, including the water buyers' income. Although long-term effects of rationalization of power subsidies differ, the sharp short-term disruptions of subsidy removal, along with the direct influence of vote-bank politics, make the implementation of such a policy complicated. Therefore, their conclusion is that although it might be easy to discuss subsidy reductions (through metering and consumption-linked power pricing) as a solution of India's energy and groundwater problems, such alternatives are unrealistic (Shah, Giordano, and Mukherji, 2012: 1000-01).

Moreover, as described earlier, switching to diesel pumps is no longer feasible in many areas with difficult hydrogeological circumstances (such as hard-rock areas) in India, which is the core area of the food-water-energy nexus. Based on such considerations, Shah, Giordano, and Mukherji (2012) proposed several second-best solutions, such as the Jhotigram (lighted village) scheme in Gujarat, an intelligently rationed power supply under a flat tariff (Shah and Verma, 2008; Shah, 2009; Shah and Chowdhury in this volume). Shah also proposed recharging schemes of groundwater for Peninsular India (and Baluchistan in Pakistan), including a program to convert tanks to percolation ponds in Tamil Nadu and other neighboring states (Shah, 2009: 218-23). ${ }^{26}$

In the eastern half of the country, however, the most important and basic policy would be to promote the electrification of diesel pump-sets to exploit underused groundwater resources for agricultural development and poverty alleviation. Reducing the difficulties of management inefficiency in the power utilities would be an important prerequisite. The introduction of solar pumps, as described later, with appropriate institutional settings, is a potentially very attractive opportunity in the future for the region as a whole, including Bangladesh and Nepal Terai.

\section{Summary and conclusions}

\subsection{Summary of discussion}

This essay provided an overview of the food-water-energy nexus in India, with some supplementary information for neighboring South Asian countries such as Pakistan, Bangladesh, and Nepal Terai. Finally, we summarize the major points discussed herein.

The food-water-energy nexus in India emerged during the decade from the mid-1970s when a flat tariff de-linked to actual electricity consumption was introduced into electric pumps for irrigation. The primary reason for abolishing the metering system and shifting to flat tariff was to save wage bills for meter readers, but the increased patronage of Indian politics after the late 1970s amidst its shift from the Congress-dominant to the multi-party system strongly promoted such a shift. We reported (as explained in note 6) that the incremented wage bill difficulties encountered by state governments at that 
time were based on factors inherent to agriculture, but also partly on Indian history: the difficulties arose along with its historical development path from the era of British India.

The nexus has mainly deepened in the arid or semi-arid western half of the Indian subcontinent because the humid eastern half of the subcontinent de-linked electricity from groundwater extraction since the 1990s by 'de-electrification' or 'dieselization,' by various policy measures different between Odisha and Bangladesh, and Bihar, Jharkhand, West Bengal and Nepal Terai. Therefore, a highly contradictory situation emerged: groundwater has been overexploited in the water-scarce western-half regions, causing closely interrelated and severe issues of groundwater depletion (and hence unsustainable food production) and bankruptcy of the power sector, in sharp contrast to the water-abundant eastern-half regions, where groundwater development has been largely limited and opportunities of groundwater-led growth have been frustrated. The international price hike of diesel oil since the late 1990s adversely affected the latter regions more severely.

Commercial losses of SEBs grew rapidly after the mid-1980s. The proportion of agricultural power subsidies to gross fiscal deficits of the state governments rose sharply from 15-20 percent to 30-65 percent by the 1990s, except for the states in East India. Power sector reforms started in India from 1991. Among various measures taken in the reform process, the crucially important ones included the unbundling of SEBs into generation, transmission, and distribution corporations, and the establishment of the SERC in each state. However, although the proportion of agricultural power subsidy to the state governments' gross fiscal deficits declined in general to 30-40 percent after the late 1990s, the agricultural power subsidy remains the most important factor affecting commercial losses of SEBs. Rationalization of tariffs for elimination of the commercial losses of SEBs did not progress as expected, mainly because of political interventions backed by demand from the beneficiary farmers. Therefore, the crucially important issue of the food-water-energy nexus in India remains largely unresolved.

India's groundwater crisis and power industry crisis must be improved together because they are two sides of the same coin (Shah, Giordano, and Mukherji, 2012: 1005). Theoretically, the solution is simple and straightforward: abolish flat tariffs and reintroduce a metering system to eliminate agricultural power subsidies on one hand, and give electric pump-set owners the appropriate incentives to conserve water on the other hand. However, considering the political circumstances in India (vote-bank politics) and its short-term disastrous adverse impacts on food production and farmers' income, such a policy option is unrealistic. Apparently, no other means exist except for some second-best solutions, as described in the text, following arguments by Tushaar Shah and others. 


\subsection{Selected future research agenda}

The food-water-energy nexus in India and South Asia is definitely an important and urgent issue to be resolved in an appropriate manner. Finally, among the various future research agenda items related to the nexus issue, two agendas are listed below with some preliminary discussion.

\subsubsection{Effects of solar irrigation pumps in different hydrogeological settings}

A growing number of countries around the world, including India and Bangladesh, have launched programs for disseminating solar irrigation pumps, given the exponentially dropping price of solar panels in recent years (IREA, 2016). However, the high initial capital cost of photovoltaic (pv) panels persists as an important barrier to their widespread use. Therefore, at this moment, to make solar irrigation systems accessible to farmers, instruments are necessary to either improve access to credit or bring down the capital cost of systems to affordable levels. The state government of Rajasthan, for instance, launched a Rs.515 crore scheme in 2011 to provide subsidized solar irrigation systems to 10,000 farmers over three years. The scheme provides farmers with 86 percent subsidy on the capital cost of the pump. Farmers receive a subsidy of Rs.461,820 from the government and pay only Rs.75,180 as their share (Kishore, Shah, and Tewari, 2014). ${ }^{27}$

Solar pumps have a near zero marginal cost of operation, thereby raising concerns of water over-withdrawal. They are similar to electric pumps, which pay a flat tariff for electricity (Kishore, Shah, and Tewari, 2014). Several programs therefore offer packaged drip-irrigation or micro-irrigation options, while simultaneously placing a cap on the pump receiving public support, which are however effective only in the short term. A proposed solution is that solar pumps export surplus electricity to the grid. IREA (2016) introduced cases of pilot projects and schemes in Karnataka and Gujarat. ${ }^{28} \mathrm{~A}$ crucially important issue here is, however, how to save transactions costs for electrical utilities to buy electricity from widely dispersed and low-capacity solar pump operations.

As Kishore, Shah, and Tewari (2014) concluded, with appropriate promotional strategy and incentives, solar pumps can attack India's invidious nexus between energy and groundwater irrigation and change it for the better. Aggressive promotion of solar pumps in groundwater-abundant eastern India can catalyze an evergreen revolution there. The same strategy in western and southern India, however, can increase stress on depleted groundwater resources.

In East India in our term, including Bangladesh and Nepal Terai, research must be done for full exploitation of the development potential provided by solar pump irrigation technologies, while addressing possible negative side effects through appropriate institutional settings. Although endowed with ample groundwater resources, the case of Bangladesh shows 
that groundwater depletion, especially in the later dry season, might hamper the development of solar pumps, and might also cause severe inequities among farmers.

\subsubsection{Functioning of the pump irrigation service markets}

The economic welfare of the water buyers, most of whom are small/marginal farmers or sharecroppers/tenants with lower socioeconomic status in South Asian rural societies, depends on how irrigation service markets function. Given the utmost importance of this issue, many research activities have already been conducted in various areas of the subcontinent, including effects of diesel price hikes on markets presented in this essay. However, many more topics must be addressed. Because this is not the right occasion to discuss this future research agenda completely, we can address only those issues related to our research interest. ${ }^{29}$

The issue of extremely low rice yields in Bihar and eastern Uttar Pradesh (UP) is an important aspect of rural poverty in this poorest region in India. The major reason for the low rice yield is that farmers do not apply irrigation because of the high water prices, although they use groundwater irrigation for wheat production in the same land in rabi (dry) season. Rice cultivation under rain-fed conditions in Bihar and eastern UP do not allow farmers to adopt high-yielding varieties (HYVs), resulting in the low yield. Given that almost all tube wells in the region are diesel-operated, the high prices of diesel oil have made irrigated HYV rice production simply uneconomical (Fujita, 2014).

Viewed from a wider regional context, however, first, in Punjab, Haryana, and western Uttar Pradesh, farmers grow rice (in the monsoon season) by application of frequent groundwater irrigation. Second, in West Bengal and Bangladesh, farmers grow boro rice (in the dry season) with frequent application of groundwater irrigation as well. Farmers in vacuum pockets (Bihar and eastern UP) between these two regions alone failed to grow HYV rice because farmers cannot apply frequent irrigation. The major difference between 'Punjab, Haryana and western UP' and 'Bihar and eastern UP' is, of course, the source of energy (electricity versus diesel) and the associated power subsidy. Why are farmers in Bihar and eastern UP unable to adopt HYV, whereas farmers in West Bengal and Bangladesh are able to do so, in spite of using the same diesel-operated tube well technologies?

A crucially important factor seems to lie in the different contractual arrangements in irrigation service markets between the two regions: spot market transactions (fixed charge per hour of irrigation) versus wholeseason contract (fixed charge per acre ${ }^{30}$ ). Under what conditions the wholeseason contract is preferred might be one of the key issues. ${ }^{31}$ The difference in the potential rice yields between the rainy and the dry season must be considered. The potential role of solar pump technologies in Bihar and eastern UP (as well as in West Bengal, Bangladesh, and Nepal Terai) must also be fully investigated. 


\section{Notes}

1 The issue has usually been taken up more simply, as the nexus between energy and water (Mukherji, 2007; Shah, Giordano, and Mukherji, 2012).

2 By contrast, Bangladesh has never used a flat tariff. Pakistan introduced once in 1989 but returned to the metering system in 2000 in the major provinces of Punjab and Sind (Shah, Singh, and Mukherji, 2006). Nepal too charges metered rates with very little subsidy for tube wells in the Terai area (Shah, 2009).

3 However, the flat tariff has at least one positive consequence. As Shah (1993) argued, it depressed the marginal cost of lifting groundwater to near-zero. Therefore, if water is sold to neighboring farmers, resource-poor water buyers also benefit from the power subsidy because well-owners tend to charge low water prices.

4 The problem of huge T\&D losses is a common issue throughout South Asia. The same figure (percentage of output) in Pakistan remained around 17 percent in 2010, although it had declined from 27 percent in 2000 (Batti, Lodhi, and ul Haq, 2015). In Bangladesh, however, it declined more rapidly from 26.1 percent to 11.0 percent, respectively, during 2000-01 and 2015-16 (Bangladesh Power Development Board, 2016).

5 Shah, Giordano, and Mukherji (2012) more generally referred to it as "transaction costs," which include not only costs of installing meters, repair and maintenance of broken meters, reading meters, billing farmers and collecting metered electricity charges, but also the cost of controlling meter tampering, underreporting, and under-billing of electricity consumption by SEB ground staff in collusion with farmers. (p. 997)

6 Shah attributed the high transaction costs to the inherent nature of agriculture with millions of (spatially) dispersed users (Shah, 2009), which seems to be valid. However, the authors add here some points that are unique to the Indian subcontinent in its historical path dependency. First, as the case of UP State demonstrates, even if the government tried to save wage bills by contracting, it soon encountered failure because of intervention from labor unions. Second, high wages paid even to the field-level staff seemed to be "accepted" by the rural general public mainly because of the highly stratified rural socio-economic structure in India. Third, backed by the strong support from labor unions and/or politicians, the fully paid field-staff soon lost labor discipline, which worsened the situation further. The case of operators and assistants assigned to operate and manage state-owned deep tube wells (DTWs) constructed in India from the 1950s to mid-1960s can be referred to here as the other typical case. In West Bengal, for instance, an operator and two assistants were employed for a DTW, but they did not work properly for 35 years or so even though (or, because) they were fully paid and protected; farmers had to employ operators by themselves on a seasonal basis (Fujita, 2010).

7 The years of introduction of flat tariff in the major states of India were the following: 1978 in Haryana and Maharashtra, 1979 in Rajasthan, 1981 in Karnataka, 1982 in Andhra Pradesh, and 1984 in Tamil Nadu.

8 Wells are classified into wells with or without pump-sets. Wells without pumpsets are operated using either animal labor or human labor. The major farm implements used for bullock-operated wells in India include Charas and Persian wheels. The latter were especially important in the Indian subcontinent (Shah, 2009: 10).

9 The result of the Minor Irrigation Census, however, showed a decline in the number of groundwater structures in east India (including Assam, Bihar, Jharkhand, Odisha and West Bengal) from 2000-01 to 2006-07 (Mukherji, Rawat, and Shah, 
2013). However, the movement of groundwater structures in central India was not clarified in the same article because they combined central India with west India.

10 The increase of diesel pump-sets in Bangladesh was remarkable. The number of deep tube wells (DTWs), shallow tube wells (STWs), and low-lift pumps (LLPs) increased from $13,800,93,100$, and 35,500 respectively in $1982-83$ to 21,500 , $270,300,51,000$ in $1990-91,23,180,865,210,71,310$ in $2000-01$, and 31,910 , 1,425,136, 150,610 in 2009-10 (Bangladesh Agricultural Development Corporation, 2009). 84.2 percent of STWs and 92.7 percent of were diesel-operated in 2009-10 (in contrast, 91.0 percent of DTWs were electricity-operated). The irrigated area in 2009-10 by DTWs, STWs and LLPs was, respectively, 0.77, 3.34, and 0.96 million hectares. The total area irrigated by the three types of irrigation equipment was accounted for 64.2 percent of net cropped area and 35.1 percent of gross cropped area in the country in the same year (Bangladesh Bureau of Statistics, 2015).

11 Shah (2009) classified Odisha in Group I, instead of Group II.

12 See Godbole (2002), Sharma, Chandramohanan, and Balasubramanianc (2005), Singh (2006), and Dubash and Rao (2008) for the responsibilities of SERCs.

13 To promote the reform process, the Act also instituted rules promoting a) the deregulation of licensing for the generation business, b) open access in distribution, and c) the power trading business. See Planning Commission (2011) for details of the reforms and the Electricity Act of 2003.

14 See Singh (2012) and Kaur and Sharma (2012) for arguing the agricultural power subsidy issue in Punjab after the mid-1990s to recent years.

15 See Shah (2009: Chapter 5) for more details.

16 However, even in Bangladesh, the intensive groundwater development for irrigation recently caused a shortage of water at the end of dry season. According to Rahman, the peak period of boro (dry-season rice) production requires more water for flowering. But the groundwater table falls and the STW engine fails to pump water in its normal capacity. Farmers have put their machine below the ground level (10-20 feet) by digging a hole and pumping water from the bottom of that hole. It usually increases the cost of irrigation. At that time it is not unlikely that the STW owner ensures his own plots' irrigation only. It encourages refusal of the water buyer's plot irrigation (Rahman, 2015: 15).

17 WEMs include electric or diesel pump-sets used to lift water from boreholes, open wells, or even rivers (Shah, 2009: 29).

18 At US\$0.075 (Rs.2) per kilowatt hour of metered electricity charge, pump irrigation would become uneconomic for most farmers in North Gujarat, western Rajasthan, Andhra Pradesh, Karnataka, and Tamil Nadu (Shah, 2009: 149). The fact that the average tariff for agriculture is approaching Rs. $2 / \mathrm{kWh}$ (Figure 7.5) implies that the policy endeavors to reduce agricultural power subsidy in India would be severely constrained in the near future if this is the case.

19 See Mukherji (2005) for the political economy analysis on the contrast between the water-abundant but underexploited groundwater situation in West Bengal and the water-scarce but overexploited groundwater situation in Gujarat.

20 The case of Uttar Pradesh, where the limited budget of SEB after the introduction of the flat tariff for agriculture began concentrating in the western part of the state due to political reasons, causing the 'de-electrification' of pump-sets in its eastern part, is worth attention (Shah, 2001).

21 Early writings called these groundwater markets, a usage that has come to be widely questioned because the WEM owner does not sell groundwater, which belongs to all, but merely the service of pumping it and conveying it to the buyer's field (Shah, 2009: 254). Hereinafter, we also call it irrigation service markets. 
22 See reports of the literature listed in Shah (2009) on page 97.

23 The cost of generating electricity must have also surged, which might adversely affect the owners of electric pump-sets as well. However, in India, because of the high dependence on domestic coal (roughly 60 percent) as a raw material for electricity generation (and of course, because of the huge power subsidy given to agriculture), the effect of oil price hikes on electric pump-sets was not so serious.

24 In West Bengal, the shift from a flat tariff to metering in agricultural electricity consumption in 2007 adversely affected the groundwater economy (Mukherji et al., 2009). However, the decision of the government to abolish the system of electric tube well permits in November 2011 caused a rapid increase in the area under boro rice cultivation, whereas it affected adversely to the irrigation service markets (Mukherji, Shah, and Banerjee, 2012; Shah and Chowdhury in this volume).

25 However, even in Bangladesh, where no major tendency of shrinking irrigation service markets is observed, as Rahman (2015) clarified, "two part tariff" (the water buyer pays a fee at the beginning of the growing season of boro rice to secure access to the water pump. And throughout the season, when the water buyer needs irrigation, he must provide his own diesel power or pay the water seller the cost of diesel/ electricity) emerged as a major payment system in irrigation service markets, which seems to be an institutional response to the diesel price hike. Even under a traditional fixed charge system per acre in which the water buyer agrees with the water seller on a price for water at the beginning of the season and supposes to receive as much water as he wants throughout the growing season, there is a growing uncertainty for water buyers to get irrigation services, especially in the later stage of the boro rice growing season (see note 16).

26 Among the seven states of Andhra Pradesh, Gujarat, Karnataka, Madhya Pradesh, Maharashtra, Rajasthan and Tamil Nadu, 100 districts account for more than 60 percent of India's critically important and overexploited blocks. The Government of India has already launched a US $\$ 450$ million pilot scheme for a recharge movement involving dug wells (Shah, 2009: 220).

27 Kishore, Shah, and Tewari (2014) pointed out various problems arising from high subsidies. Moreover, based on the recognition that farmers tend to make choices that are privately beneficial but socially suboptimal, they recommend shifting the subsidy system from the system of offering a fraction of the total cost ( 85 percent now) to a new system where the government provides a fixed amount as a lump sum subsidy.

28 See Shah, Verma, and Durga (2014) for Karnataka.

29 Shah and Chowdhury in this volume (Chapter 11) address an important issue that has arisen recently in West Bengal: shrinking irrigation service markets and expansion of seasonal lease of land by tube well owners. An important question is why the markets shrank in spite of the increased density of tube wells after abolishment of the system of electric tube well permits in November 2011.

30 However, the other contractual arrangement is called the "two part tariff" in which water buyers pay diesel costs while maintaining the basic characteristic of whole-season contract that emerged in Bangladesh. See note 25.

31 Aditi Mukherji pointed out that "in West Bengal, as a rule of thumb, diesel WEM owners prefer to charge an hourly water rate (Rs./hour), while the electric WEM owners prefer a crop- and area-based seasonal water charge (Rs./area/ season)" (Mukherji, 2007: 6419-20). In West Bengal, Mukherji et al. (2009) pointed out that (i) crop and season with cash contract (Rs./bigha/crop) are found for aman and boro paddy; (ii) hourly rate (Rs./hour) is common for all other crops and (iii) one time crop area specific contracts (Rs./bigha/irrigation) usually found in case of crops with low water requirement such as mustard, wheat, and sesame" (p. 5534). 


\section{References}

Bangladesh Agricultural Development Corporation (2009). Minor Irrigation Survey Report 2008-09, Dhaka: Bangladesh Agricultural Development Corporation, Ministry of Agriculture, Government of Bangladesh.

Bangladesh Bureau of Statistics (2015). Yearbook of Agricultural Statistics-2013, Dhaka: Bangladesh Bureau of Statistics.

Bangladesh Power Development Board (2016). Annual Report 2015-16, Dhaka: Bangladesh Power Development Board.

Batti, S. S., M. U. U. Lodhi, and S. ul Haq (2015). "Electric Power Transmission and Distribution Losses Overview and Minimization in Pakistan," International Journal of Scientific \& Engineering Research, vol. 6(4), 1108-12.

Central Electricity Authority (1966 and 1976). Public Electricity Supply, All India Review, General Review, New Delhi: Ministry of Power, Government of India.

Dubash, N. K. and S. C. Rajan (2001). "Power Politics: Process of Power Sector Reform in India," Economic and Political Weekly, vol. 36(35), 3367-90.

Dubash, N. K. and D. N. Rao (2008). "Regulatory Practice and Politics: Lessons from Independent Regulation in Indian Electricity," Utilities Policy, vol. 16(4), 321-31.

Fujita, K. (2010). Re-thinking Economic Development: The Green Revolution, Agrarian Structure and Transformation in Bangladesh, Melbourne: Kyoto University Press and Trans Pacific Press.

Fujita, K. (2014). "How Agriculture in Bihar Lagged Behind: Implications for Future Development," in Tsujita, Y. ed., Inclusive Growth and Development in India: Challenges for Underdeveloped Regions and the Underclass, London: Palgrave Macmillan: 40-73.

Godbole, M. (2002). "Electricity Regulatory Commissions: The Jury Is Still Out," Economic and Political Weekly, vol. 37(23), 2195-200.

International Renewable Energy Agency (IREA) (2016). Solar Pumping for Irrigation: Improving Livelihoods and Sustainability, Abu Dhabi: International Renewable Energy Agency.

Kahnert, F. and G. Levine (1993). Groundwater Irrigation and the Rural Poor: Options for Development in the Gangetic Basin, Washington, DC: The World Bank.

Kaur, R. and M. Sharma (2012). "Agricultural Subsidies in India: Case Study of Electricity Subsidy in Punjab State: An Analysis," Journal of Scientific and Research Publications, vol. 2(10), 1-7.

Kishore, A., T. Shah, and N. P. Tewari (2014). "Solar Irrigation Pumps: Farmers' Experience and State Policy in Rajasthan," Economic and Political Weekly, vol. 49 (10), 55-62.

Kumar, M. D. (2007). Groundwater Management in India: Physical, Institutional, and Policy Alternatives, New Delhi: Sage Publications.

Mukherji, A. (2005). "Political Ecology of Groundwater: The Contrasting Case of Water-Abundant West Bengal and Water-Scarce Gujarati, India," Hydrogeology Journal, vol. 14, 392-406.

Mukherji, A. (2007). "The Energy-Irrigation Nexus and Its Impact on Groundwater Markets in Eastern Indo-Gangetic Basin: Evidence from West Bengal, India," Energy Policy, vol. 35, 6413-30.

Mukherji, A. (2017). "Managing Energy-Irrigation Nexus: Insights from Karnataka and Punjab States in India," in Villholth, K. G., van der Gun, J., Lopez-Gunn, E., 
Conti, K. and Garrido, A. eds., Advances in Groundwater Governance, New Delhi: Routledge: 284-302.

Mukherji, A., B. Das, N. Majumdar, N. C. Nayak, R. R. Sethi, and R. R. Sharma (2009). "Metering of Agricultural Power Supply in West Bengal: Who Gains and Who Loses?" Energy Policy, vol. 37, 5530-39.

Mukherji, A., S. Rawat, and T. Shah (2013). "Major Insights from India's Minor Irrigation Censuses: 1986-87 to 2006-07," Economic and Political Weekly, vol. 48 (26\&27), 115-24.

Mukherji, A., T. Shah, and P. S. Banerjee (2012). "Kick-Starting a Second Green Revolution in Bengal," Economic and Political Weekly, vol. 47(18), 27-30.

Planning Commission (1986, 1990, 1992, 2000, 2001, 2002, 2011, and 2013). Annual Report on the Working of State Power Utilities and Electricity Departments, New Delhi: Planning Commission, Government of India.

Power Finance Corporation Limited (2008). Report on the Performance of the State Power Utilities for the Year 2004-05 to 2006-07, New Delhi: Power Finance Corporation Limited.

Rahman, M. S. (2015). Determinants of Water Price, Contract Choice and the Rice Production Inefficiency in Groundwater Irrigation Markets in Bangladesh, Tokyo: $\mathrm{PhD}$ thesis submitted to Bangladesh Agricultural University.

Ruet, J. (2005). Privatising Power Cuts? Ownership and Reform of State Electricity Boards in India, New Delhi: Academic Foundation.

Shah, T. (1993). Groundwater Markets and Irrigation Development: Political Economy and Practical Policy, Bombay: Oxford University Press.

Shah, T. (2001). Wells and Welfare in the Ganga Basin: Public Policy and Private Initiative in Eastern Uttar Pradesh, IWMI Research Report No. 54, Colombo: International Water Management Institute.

Shah, T. (2007). "Crop per Drop of Diesel? Energy Squeeze on India's Small-Holder Irrigation," Economic and Political Weekly, vol. 32(52), 4002-09.

Shah, T. (2009). Taming the Anarchy: Groundwater Governance in South Asia, New Delhi: Routledge.

Shah, T., M. Giordano, and A. Mukherji (2012). "Political Economy of the Energy-Groundwater Nexus in India: Exploring Issues and Assessing Policy Options," Hydrogeology Journal, vol. 20, 995-1006.

Shah, T., O. P. Singh, and A. Mukherji (2006). "Some Aspects of South Asia's Groundwater Irrigation Economy: Analysis from a Survey in India, Pakistan, Nepal Terai and Bangladesh," Hydrogeology Journal, vol. 14, 286-309.

Shah, T. and S. Verma (2008). "Co-management of Electricity and Groundwater: An Assessment of Gujarat's Jotirgram Scheme," Economic and Political Weekly, vol. 43(7), $59-66$.

Shah, T., S. Verma, and N. Durga (2014). "Karnataka's Smart, New Solar Pump Policy for Irrigation," Economic and Political Weekly, vol. 49(48), 10-14.

Sharma, D. P., P. S. N. Chandramohanan, and R. Balasubramanianc (2005). "Performance of Indian Power Sector during a Decade under Restructuring: A Critique," Energy Policy, vol. 33(4), 563-76.

Singh, A. (2006). "Power Sector Reform in India: Current Issues and Prospects," Energy Policy, vol. 34(16), 2480-90.

Singh, K. (2012). "Electricity Subsidy in Punjab Agriculture: Extent and Impact," Indian Journal of Agricultural Economics, vol. 67(4), 617-32. 


\title{
8 Challenges of growth and sustainability
}

\section{Agriculture in Indian Punjab}

\author{
Kamal Vatta
}

PROFESSOR, PUNJAB AGRICULTURAL UNIVERSITY

Parisha Budhiraja

RESEARCH ASSOCIATE, CENTERS FOR INTERNATIONAL PROJECTS TRUST, NEW DELHI, INDIA

\section{Introduction}

\subsection{Indian agriculture}

After gaining independence, India faced the daunting challenge of attaining food security to feed its population of nearly 350 million, a large proportion of which was estimated as being seriously poor, with most children experiencing malnourishment (Dev and Sharma, 2010; Ittyerah, 2013). Prioritizing agricultural growth was an important strategy to reduce poverty. However, a slowdown in growth of agricultural GDP from 2.9 percent per annum in $1950-51$ to 1.3 percent per annum in 1960-61 pushed the country back into a food deficit for the next two decades (CSO, 1988, 1989a, 1989b). Owing to the widening gap between demand for and supply of food grains, India heavily relied on importing agricultural commodities worth Rs.6,860 million during this period (Rath and Patvardhan, 1967). Frequent droughts and ever-rising imports further strengthened the argument that agricultural growth was crucial for the overall development of the economy.

The above pattern of slow growth was reversed during the late 1960s, as price reforms and new technologies for agriculture were adopted. The introduction of high-yield varieties (HYVs) and the expansion of irrigation networks brought a substantial increase in agricultural productivity while stimulating agricultural growth. The Green Revolution ushered in a dramatic increase in domestic food grain production, eliminating the need for food grain imports. Punjab, at the center of the Green Revolution, had been at the forefront of achieving food security for the nation. Because of the increased use of HYVs, irrigation, and adoption of a package of improved agricultural practices, wheat production rose remarkably from 1.9 to 5.6 million tons over 
five years (Parayil, 1992; Gill, 1994). Yet, the continued use of intensive agricultural practices over many decades in Punjab, necessitated by the Green Revolution, had harsh implications for groundwater usage, use of agrochemicals, groundwater pollution, agro-ecosystems, and intensification of regional inequalities (Rao, 1998; World Bank, 2008; Hira, 2009).

The rise in agricultural productivity leveled off in Punjab after 1975 (Chengappa, 1989). The negative effects of intensive agriculture have been exacerbated over time by the reckless utilization of groundwater resources, heavy subsidies on agricultural power consumption, and declining profitability and crop diversity. The rise in water and power consumption has the potential to seriously threaten the sustainability of agriculture and farmers' incomes. This study highlights patterns of agricultural growth along with its determinants, identifies the major challenges for sustainability of agriculture in Punjab, and outlines alternatives for achieving long-term sustainability.

\subsection{Agriculture in Punjab}

Punjab, located in northwestern India, is a prosperous state (Map 8.1). Of its geographical area of 5,036 thousand ha, the net cultivated area in the state is 4,158 thousand ha. Punjab, as a leading adopter of new technologies, has performed to an exemplary degree in the agricultural sector over the last five decades. The introduction of HYVs together with assured irrigation, use of chemical fertilizers, farm mechanization, and effective food grain procurement policies paved the way for its success in the Green Revolution.

Punjab's astounding agricultural growth is apparent in its increased wheat production from 1.9 to 5.6 million tons during 1965-72 (Zarkovic, 1987). The growth in rice production has been equally remarkable. During the last ten years, Punjab state alone has contributed almost half of the rice and one-third of the wheat to the central pool of food grains to ensure national food security. Currently, almost 19 percent of India's wheat production, 11 percent of its rice production and 5 percent of its cotton production come from Punjab, from merely 1.5 percent of the geographical area of the country. It is often called the 'food basket of India' or the 'granary of India' for this reason. In 2014-15, the state's share of the nation's product was 24.2 percent of paddy and 41.5 percent of wheat. Current levels of paddy productivity (6.2 tons/ha) and wheat productivity (5.1 tons/ha) are comparable to productivity levels in developed countries. The per-capita income at 2004-05 prices is Rs.44,885, giving Punjab a rank of seventh in per-capita income among the major states in India.

\section{The performance and contributions of Punjab agriculture}

The success of the Green Revolution in Punjab was supported by the intensification of Punjab agriculture over time. This intensification was led 


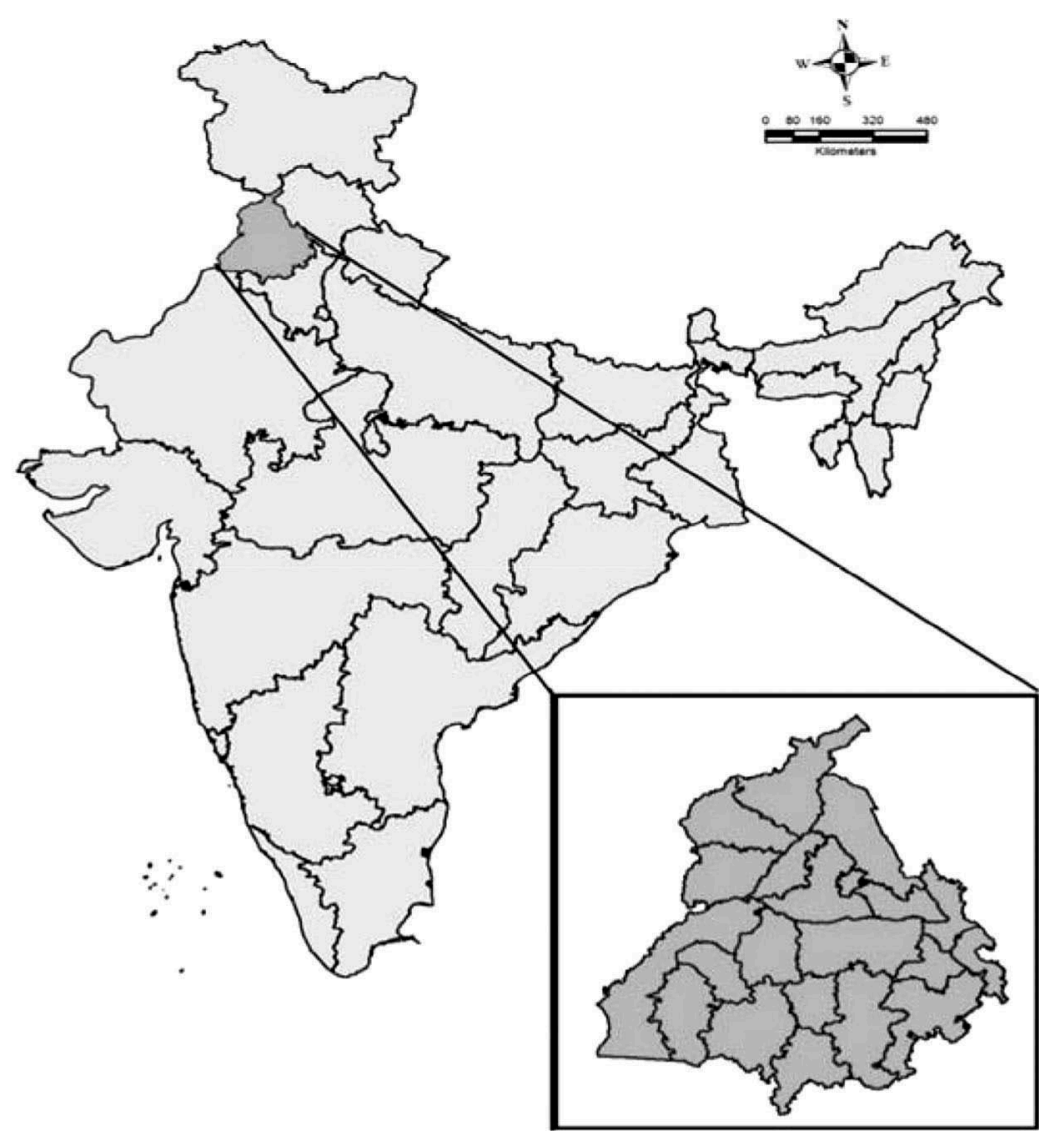

Map 8.1 Location of Punjab in India

Source: Maps-India-in.com.

by the successful introduction of HYVs of wheat after the mid-1960s and of rice during the early 1970s. The HYVs, coupled with expansion in irrigation infrastructure and high doses of fertilizers and chemicals, translated into higher levels of productivity. Because of the availability of new techniques of production, the land use pattern changed considerably as the net sown area progressed from 3.7 million ha in 1960-61 to 4.14 million ha in 2016 and the gross cropped area increased even more from 4.7 million ha to 7.9 million ha during that period. As a result, a marked leap in cropping intensity, from 126 percent in 1965-66 to 191 percent in 2014-15 was achieved, ultimately resulting in higher productivity (Table 8.1 ). The crop production pattern in Punjab is dominated by rice-wheat cultivation, which together account for more than 80 percent of the gross cropped area (GCA). 
Table 8.1 Changes in Punjab Land Use, 1960-2016

\begin{tabular}{lll}
\hline Growth Indicator & From & To \\
\hline Irrigated area (as \% of gross cropped area) & $56 \%(1960-61)$ & $99.9 \%(2014-15)$ \\
Cropping intensity & $126 \%(1960-61)$ & $191 \%(2014-15)$ \\
Area under high-yield wheat varieties & $6 \%(1967-68)$ & $100 \%(2014-15)$ \\
Area under high-yield rice varieties & $35 \%(1967-68)$ & $100 \%(2014-15)$ \\
Fertilizer use (kg/ha of net area sown) & $12(1965-66)$ & $460(2014-15)$ \\
Chemical use (tonnes of technical grade) & $3200(1980-81)$ & $5750(2014-15)$ \\
Power use in agriculture (kwh/ha) & $1,174(1967-68)$ & $4,878(2015-16)$ \\
Electric power consumption (million kWh) & $340.7(1967-68)$ & $12,029(2015-16)$ \\
\hline
\end{tabular}

Source: Government of Punjab, Statistical Abstract of Punjab (various issues), Chandigarh.

The state exhibited a rapid expansion in its irrigation network from 1960-61 to $2014-15$ as the net irrigated area almost doubled from 2.0 million ha to 4.1 million ha and the gross irrigated area all but tripled from 2.6 million ha to 7.7 million ha. In percentage terms, the irrigated area increased from just half to 99.9 percent. Of the total irrigated area, 72 percent was irrigated through 1.4 million tube wells; only 28 percent of the area was served by canals. The number of tube wells rose drastically from 0.192 million in 1970-71 to 1.406 million in 2014-15. The notable increase in this number was facilitated by improved productivity and profitability of rice and wheat, which made private investment in tube wells attractive. Other factors include an increased power supply to agriculture for irrigation and a favorable policy to encourage tube well connections (through easy approval for power connections). Extending irrigation in Punjab agriculture heavily depends upon power; the operational cost of electrically operated tube wells is much lower than that of diesel-operated tube wells. However, this presents severe implications for groundwater resource sustainability and ever-increasing power subsidies for agriculture in Punjab.

The introduction of HYVs of wheat and rice during the mid-1960s and early 1970s, in addition to expansion of the state's irrigation infrastructure, paved the way for large-scale adoption of HYVs. During 1967-68, only 17 thousand ha of rice area, 29 thousand ha of maize area, and 621 thousand ha of wheat area were used to cultivate HYVs. Currently, almost all food crop areas support HYV cultivation. The adoption process followed an S-shaped curve with almost non-existent tails in the cases of rice and wheat crops because of the much greater economic benefits of HYV rice and wheat (Figure 8.1).

The introduction of HYVs with assured irrigation has led to a substantially higher use of inputs such as fertilizers and agro-chemicals. The current level of fertilizer use in Punjab, 1,911 thousand nutrient tons, is 


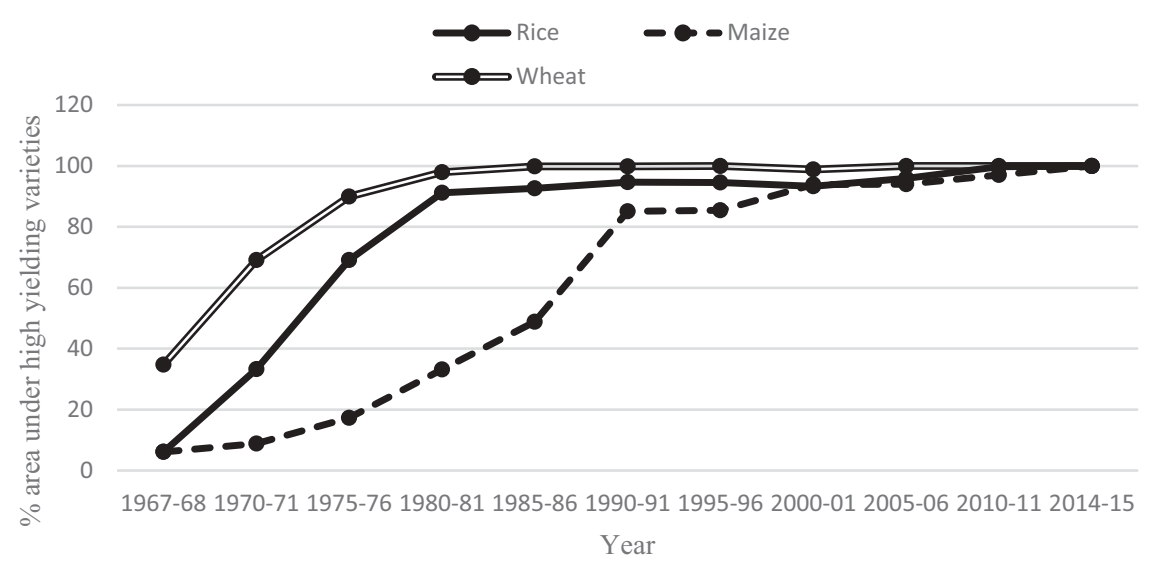

Figure 8.1 HYV Coverage for Major Food Crops in Punjab

Source: Government of Punjab, Statistical Abstract of Punjab, Various issues.

more than 40 times the fertilizer use in 1965-66. The use of agro-chemicals also increased from 3,200 tons of technical grade in 1980-81 to 7,200 tons of technical grade in 1995-96, followed by a decline to 5,750 tons of technical grade in 2014-15. The intensity of fertilizer use also increased tremendously, jumping from $12.1 \mathrm{~kg} / \mathrm{ha}$ of net sown area (NAS) in 1965-66 to $460 \mathrm{~kg} / \mathrm{ha}$ in 2014-15 (34 times). In addition, mechanization is evident from the number of tractors, which rose sharply from 50,664 in 1975-76 to 476,835 in 2013-14.

The productivity of all major crops in Punjab increased over time, but rice and wheat productivity did so at a much faster pace. Rice and wheat yields rose almost four-fold during 1966-67 to 2013-14. Production of wheat increased from $1,244 \mathrm{~kg} / \mathrm{ha}$ in $1960-61$ to $5,017 \mathrm{~kg} / \mathrm{ha}$ in $2013-14$; that of rice swelled from $1,009 \mathrm{~kg} / \mathrm{ha}$ to $3,952 \mathrm{~kg} / \mathrm{ha}$ over the same period. By contrast, no significant improvement was found in the output of pulses and oilseeds. Over the same period, maize productivity also increased from $1,383 \mathrm{~kg} / \mathrm{ha}$ to $3,898 \mathrm{~kg} / \mathrm{ha}$. Although the state has realized substantial gains in maize yields, the initial gains in productivity of rice and wheat during the first decade of the Green Revolution have accelerated agricultural growth and have shifted cropping patterns in favor of rice and wheat crops.

Enhanced productivity and an expansion in the area under food crop cultivation (rice and wheat) in Punjab led to greater levels of food production, with an increase from 3.1 million tons in 1960-61 to 26.2 million tons in 2014-15. Because the volume of food produced in Punjab was much higher than that required for its own consumption, a large proportion of grain production contributed to the national food pool, underpinning national food security. Punjab contributed only 0.13 million tons of rice and 0.57 million 
tons of wheat in 1966-67 but made a huge leap to reach the level of 8.63 million tons of rice and 10.21 million tons of wheat in 2010-11, placing it at the forefront of contributions to the national pool of food grains.

The Government of India instituted The Agricultural Prices Commission (now the Commission for Agricultural Costs and Prices; CACP) in January 1965. This was intended as an initiative to procure food grain and to establish a balanced and integrated price structure that would meet overall economic needs while safeguarding the interests of producers and consumers. The minimum support price (MSP) of crops including rice and wheat were comparable in proportionate terms. The higher yields for these two food crops led to higher gross returns and therefore, greater profitability. The gross returns from wheat and paddy remained markedly higher than those of other crops, which lured farmers into expanding the area dedicated to paddy and wheat. Increasing amounts of benefits accrued to the farmers, ranging from Rs.3,662 to Rs.56,819 for wheat and Rs.4,072 to Rs.72,493 for paddy. Furthermore, despite a sharp rise in gross returns from other crops such as maize, mustard, and chickpea, rice and wheat cultivation increasingly seized the land area and thereby gradually paved the way for the prevalence of mono-culture in Punjab (Table 8.2).

Because of the higher sustainable profitability of rice and wheat crops in Punjab for more than four decades following the advent of the Green Revolution, a continuous increase in areas under rice and wheat cultivation occurred. Rice and wheat crops were being grown on less than 40 percent of the total cropped area during 1966-67, expanding to 80 percent by 2010-11, illustrating the transformational importance of rice-wheat cultivation (Figure 8.2). Wheat, being the traditional crop of the region, already

Table 8.2 Gross Returns from Paddy and Wheat vis-à-vis Other Important Crops in Punjab (Rs./ha)

\begin{tabular}{llllll}
\hline Year & Wheat & Paddy & Maize & Mustard & Chickpea \\
\hline $1970-71$ & 1720 & 1627 & 834 & 864 & 673 \\
$1980-81$ & 3662 & 4072 & 2103 & 2388 & 2017 \\
& $(113)$ & $(150)$ & $(152)$ & $(176)$ & $(200)$ \\
$1990-91$ & 8001 & 10,597 & 4198 & 7038 & 5576 \\
& $(118)$ & $(160)$ & $(99)$ & $(195)$ & $(176)$ \\
$2000-01$ & 27,243 & 27,163 & 13,631 & 13,069 & 13,842 \\
& $(240)$ & $(156)$ & $(225)$ & $(85)$ & $(148)$ \\
$2010-11$ & 56,819 & 72,493 & 48,637 & 40,288 & 71,955 \\
& $(108)$ & $(167)$ & $(257)$ & $(208)$ & $(419)$ \\
$2014-15$ & 63,337 & 80,598 & 44,980 & 32,869 & 66,510 \\
& $(11)$ & $(11)$ & $(-7.5)$ & $(-18)$ & $(-7.5)$ \\
\hline
\end{tabular}

Note: Gross returns were estimated by multiplying the farm harvest prices of different commodities with their average yields for the given year. Figures in parentheses are percent changes over the prior decade. 


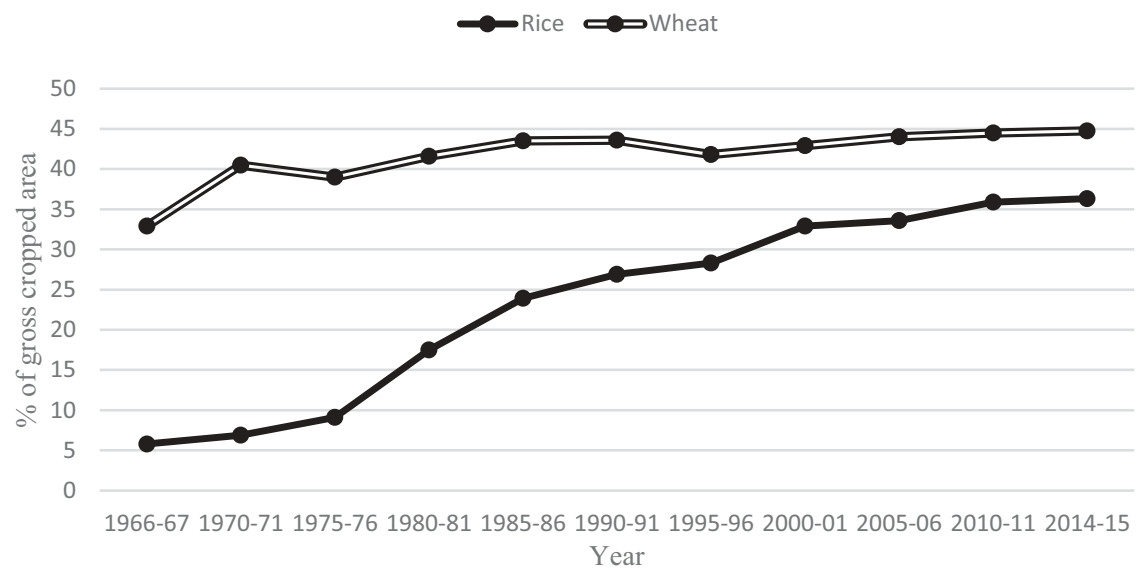

Figure 8.2 Rice and Wheat Dominance in Punjab Crop Sector

Source: Estimated from data referred from the Statistical Abstract of Punjab, Various Issues.

accounted for almost one-third of the cultivated area in 1966-67. This proportion increased to 44.75 percent in 2013-14. Rice was introduced mainly during the 1970s. Although it occupied just about 6 percent of the area in 1966-67, it accounted for more than 36 percent of the gross cropped area in 2013-14. ${ }^{1}$

Apart from being introduced on newer lands in the state, rice and wheat cultivation also replaced existing crops, such as maize, coarse cereals, pulses, and oilseeds. The following figure presents an illustration of that phenomenon (Figure 8.3).

The area under rice cultivation was merely 285 thousand ha in 1966-67. This steadily grew to 2.84 million ha during $2014-15$. The area under wheat cultivation also more than doubled from 1.6 million ha to 3.5 million ha during this period. In summary, the success of the Green Revolution in Punjab lay in the marked growth in productivity of rice and wheat crops attributable to large-scale adoption of HYVs, assured irrigation and intensive use of inputs such as fertilizers and chemicals.

Despite its remarkable success, the Green Revolution came under severe criticism after the 1970s and up to the present day for ecological and socioeconomic reasons. According to Ghuman et al. (2007), the Green Revolution transformed the food-poor Indian economy into a self-sufficient economy. However, by the mid-1980s, the Green Revolution started fading in Punjab as yields and production experienced a tendency towards stagnation. Although this technology has proved to be an important turning point in transforming India from being a net importer to a self-sufficient or marginal exporter of food grains, it was achieved at great cost to the nation, both 


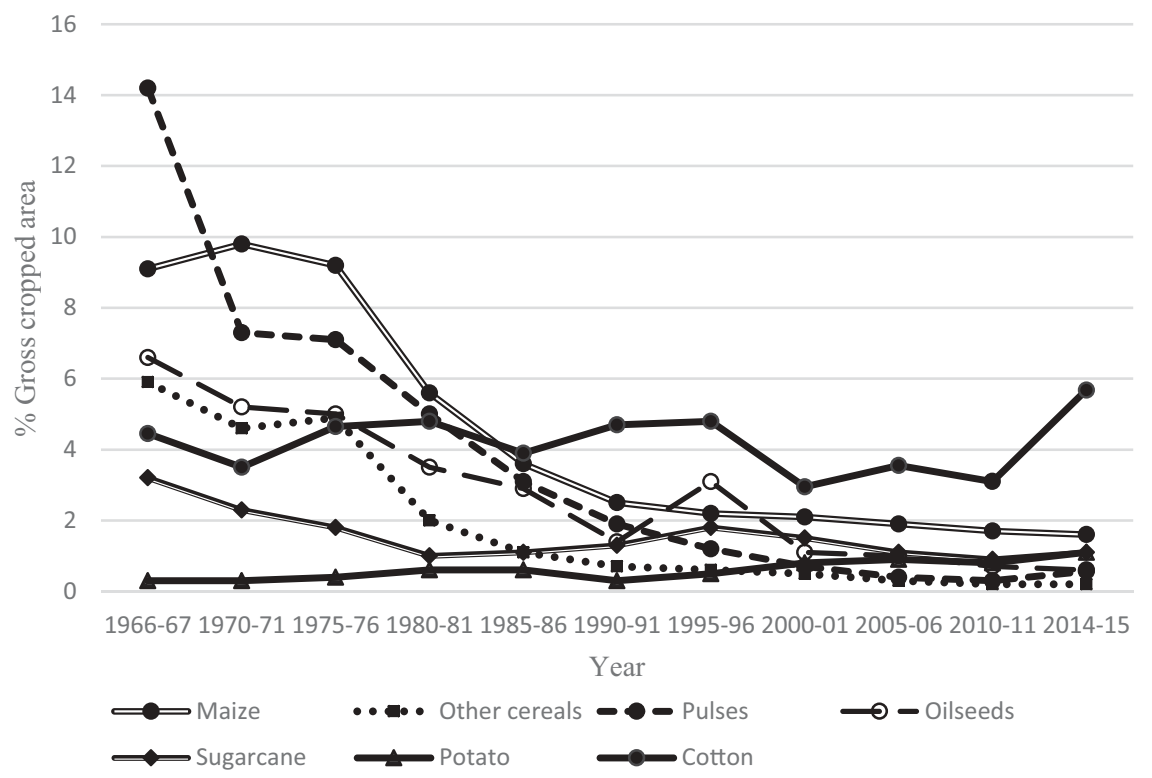

Figure 8.3 Other Crops in Punjab

Source: Estimated from data referred from the Statistical Abstract of Punjab, Various Issues.

environmentally and socially (Ramakrishnan, 2008). A salient criticism directed against the success of the Green Revolution was that high yields could not be obtained even under optimum conditions: optimal irrigation, intensive use of fertilizers, monoculture (for the rational use of machinery and agricultural equipment), and pest control using chemical pesticides (Glaeser, 1987).

Because emphasis has been laid invariably on improving overall production, intensive agriculture practices in Punjab have had severe implications for crop diversity, the sustainability of natural resources, power use in agriculture, burdens of power subsidies on state governments, and resource use efficiency in agriculture. Rising costs and dwindling profitability in agriculture and the emergence of other states as important contributors to the national food pool in recent times are some of the issues confronting Punjab agriculture.

\section{Emerging issues and challenges for Punjab agriculture}

After following a high growth trajectory for more than three decades, Punjab agriculture has shown a marked slowdown during the last decade. It is evident, as Figure 8.4 shows below, that food production in Punjab grew 


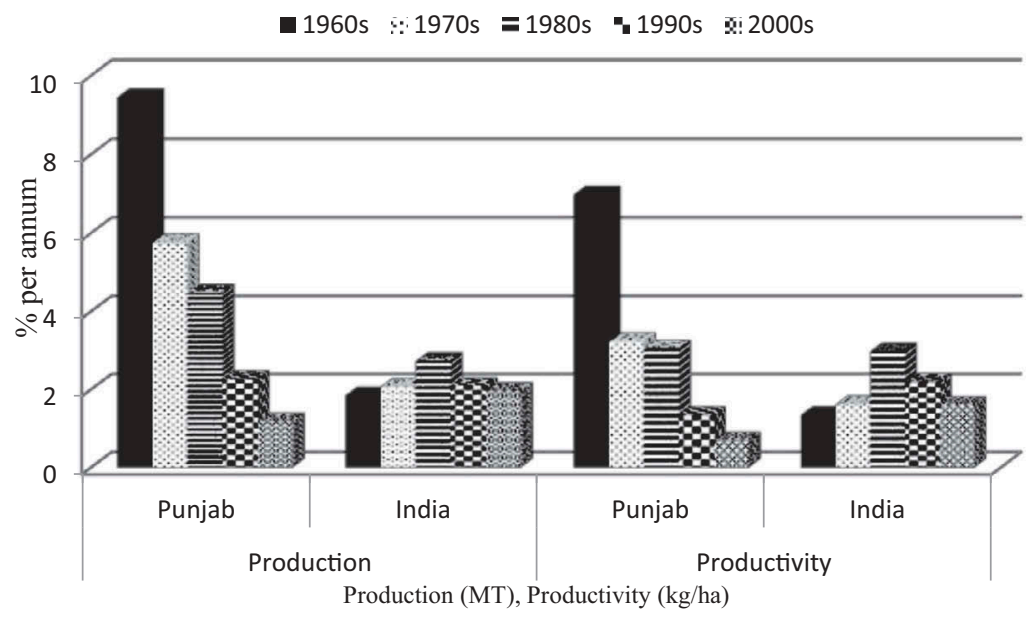

Figure 8.4 Food Production and Productivity Growth: Punjab vs. India Source: Government of India, Agricultural Statistics at Glance.

at more than 9 percent per annum during the 1960s and between 4-6 percent per annum during the 1970s and 1980s. Trends in productivity growth in Punjab were similar. However, the growth rate of food productivity was lower than that of food production because expansion in the area also contributed to enhanced food production.

Two important observations must be made. First, food production and productivity growth in Punjab have slowed considerably during the last two decades. Second, the state which remained at the forefront of food production and productivity by any national standard started lagging behind even the national averages over the same period. This points to the recent emergence of other states with better performance than that of Punjab in agricultural growth and their increasing contributions to national food security. Therefore, decline or stagnation in the productivity of either one has caused a slowdown in agricultural growth during the last two decades.

Chand et al. (2011) reaffirmed a downturn in agriculture and estimated the average annual total factor productivity (TFP) growth of Indian wheat, which declined from 0.74 percent in 1986-95 to 0.4 percent in 1996-2005, whereas TFP growth for rice plummeted from 1.61 percent in the latter period, as compared to 2.51 percent in the former. Food production in Punjab followed similar trends. Moreover, various studies have underscored the disproportionate distribution of income among different size classes.

Intensive agricultural practices have led to a decline in biodiversity. The combined area under rice and wheat crops was less than 40 percent during the late 1960s. It has recently reached more than 80 percent. Shifts in 
cropping patterns tell the story of a regular decline in crop diversity. The diversification index for Punjab agriculture followed a sharp and regular decline from above 0.80 during the early 1970 s to 0.66 in 2011-12 (Figure 8.5).

It is also important to assess trends in varietal diversity for rice and wheat in Punjab. Over a long period of time, one or two varieties of rice and wheat crops have been planted on most of the cultivated area in Punjab. In the case of rice, the varietal data show that just two strains covered about half of the area under rice cultivation, most of the time. Initially, PR-106 variety of rice, released by the Punjab Agricultural University, covered 49 percent of the area under rice cultivation in 1985-86, 62 percent in 1990-91, and 49 percent in 1995-96. Later, the PR-114 variety dominated in 2000-01 (44.46 percent) and Pusa-44 during 2006-07 (38 percent). The varietal diversity index has shown an increase in the varietal diversity of rice cultivation in Punjab, with the index declining from 0.67 in 1985-86 to 0.60 in $1990-91$, and subsequently increasing regularly to reach 0.80 in 2006-07. However, a completely different trend is apparent for varietal diversity in wheat cultivation in Punjab. Kalyan Sona variety dominated in 1970-71, with more than 80 percent of the area under wheat cultivation, but WL-711 dominated in 1975-76 and 1980-81, respectively, with 73 percent and 53 percent of the wheat cultivation area. Later, almost

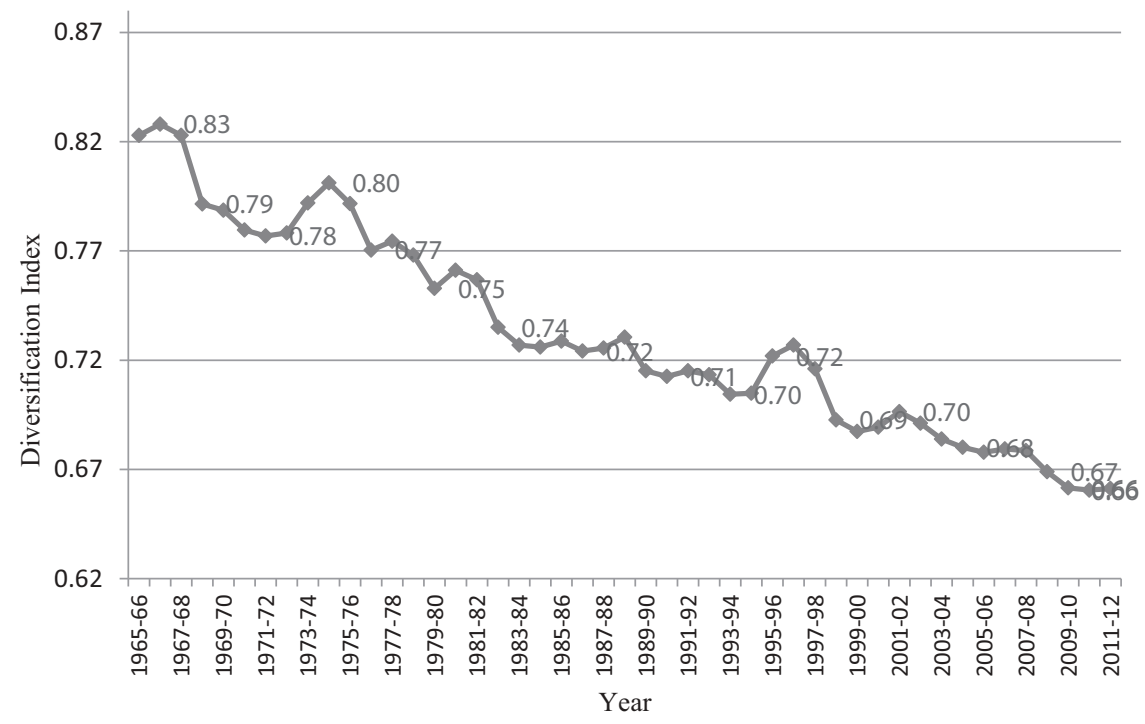

Figure 8.5 Crop Diversity Index Trends in Punjab

Source: Estimated from data collected from Government of Punjab, Statistical Abstract of Punjab, various issues. 
88-89 percent of the wheat area was occupied by the WL-343 variety. The varietal diversity index for wheat rose and fell until 1985-86, but it dipped sharply after that to near 0.2 during 2000-01 and 2005-06 (Figure 8.6). Such a sharp decline in the varietal diversity in wheat is not encouraging because it represents almost 90 percent of the area under the crop (more than 80 percent of the net sown area). Any disease outbreak could threaten the crop in the whole state, with damage causing havoc throughout the entire state agricultural economy.

Dwarf varieties of wheat and rice require more intensive irrigation than local or indigenous varieties. Therefore, one factor improving productivity during the Green Revolution era was artificial irrigation. However, the dependence of agriculture on groundwater resources increased considerably over time. Repetto (1994) asserted that the 'Green Revolution is more tube well revolution than wheat revolution.' Earlier, farmers were dependent on canals for irrigating the fields, but introduction of rice cultivation was probably the most important reason underlying the increase in artificial irrigation by tube wells and wells. The net irrigated area by canals decreased from 44.53 percent in $1970-71$ to 27.31 percent in $2008-09$, whereas the

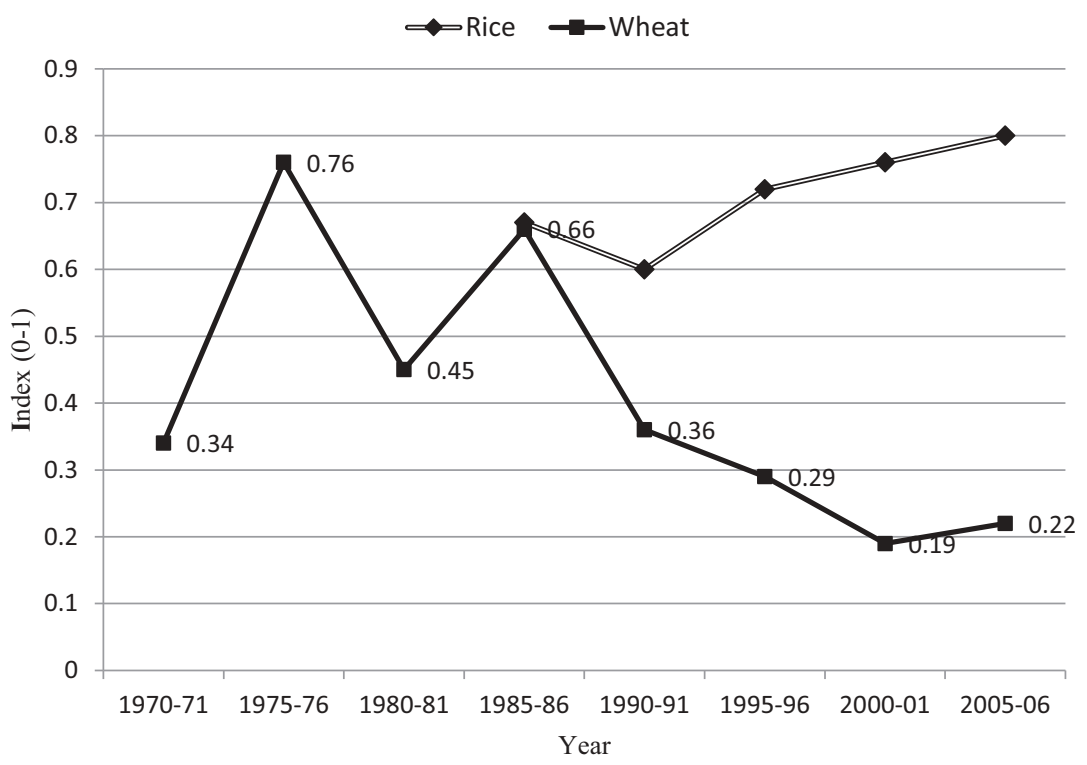

Figure 8.6 Trends in Varietal Diversity Index for Rice and Wheat in Punjab

Note: Authors' estimates from Department of Agriculture, Government of Punjab, The Crop Cutting Experiment Data of the Estimates until 1995-96 from Singh and Kalra (2002) have been used. Estimates from 1995-96 have been used from Singh et al. (2004). 
area irrigated by tube wells increased from 55.09 percent to 72.59 percent during that period. The main factor causing the transition from canal to tube well was that the surface water was unable to meet agriculture sector demands. Overexploitation of groundwater resources has led to groundwater depletion.

Hira (2009) and others have reported that groundwater depletion started only after the inception of this new technology. With increasing groundwater use for irrigation in Punjab agriculture, and the total water use exceeding the sustainable supply over time, overexploitation of groundwater resources has led to the lowering of the groundwater table. This alarming situation has jeopardized the initial benefits of the Green Revolution. Most relevant studies have largely attributed the falling water table to the rise in the area under rice cultivation. However, the government policy of providing free power for agriculture after 1997 accentuated the pace of this decline. Even before, provisions of fixed tariffs on the power use in agriculture existed. In both cases, the marginal cost of withdrawing water for irrigation turned out to be zero. No incentive existed to use water optimally with zero marginal cost. The policy also discouraged the optimal allocation of cultivation areas in Punjab from the perspective of groundwater sustainability (Figure 8.7).

In 1986, the Punjab region comprised 118 blocks. Of these, 5 blocks were 'overexploited,' 9 blocks were in a 'critical' condition, 18 blocks were 'semicritical,' and 36 blocks were 'safe.' However, of 137 blocks in 2010-11, 103 blocks were overexploited, 4 blocks were in a critical condition, 5 blocks were semi-critical, and only 25 blocks were safe (Government of Punjab, 2005). The

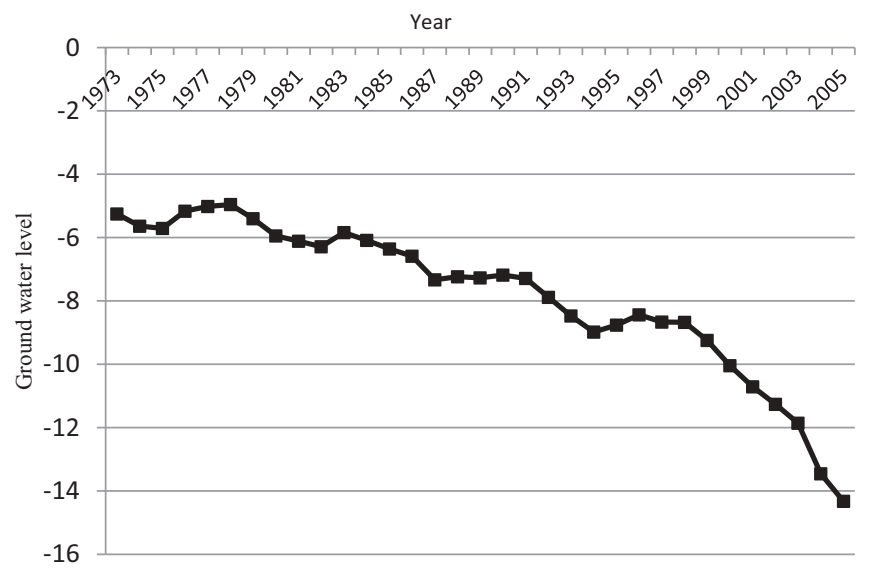

Figure 8.7 Groundwater Table in Central Punjab

Note: Department of Soil Water and Engineering, PAU, Ludhiana; Central Groundwater Board Punjab. 


\section{2}

Kamal Vatta and Parisha Budhiraja

groundwater problem is most severe in the central region, where rice is the main summer crop. To manage their production, farmers have installed individual pumps, which contribute to water table exhaustion. The fall in the groundwater that occurred up to 1998 was gradual and slow, but it became quite sharp thereafter. The government policy of providing free power for agriculture after 1997 accentuated the pace of depletion. The average annual rate of fall in the groundwater table was about $17 \mathrm{~cm}$ during the 1980s; it was more than $25 \mathrm{~cm}$ in the 1990s. However, a crisis emerged mainly during 2000-05, when the annual groundwater depletion was about $91 \mathrm{~cm}$ (Hira, 2009).

Another element contributing to environmental crisis is the reckless use of fertilizers. Water logging and soil salinity have also worsened because of the excessive use of fertilizers and other agro-chemicals. All states adopting new HYV seeds have used some fertilizers to increase their productivity. In 1965-66, Punjab was lagging behind several states in relation to fertilizer consumption per hectare. However, after 1965-66, the per-hectare consumption of fertilizers increased so sharply in Punjab that it left all other states far behind (Chadha, 1986). A comparison of per hectare usage of the pesticides among states reveals that Punjab has the highest use, consuming 923 grams of pesticides per hectare.

Apart from being excessive, the fertilizer use is also highly imbalanced. Against the recommended levels of 4: 2: 1, the NPK ratio was 18.1: 7.1: 1 in 1980-81, worsening further to 26.2: 8.3: 1 in 2011-12 (Johl et al., 2014). Chemical fertilizers reportedly account for $8-9$ percent of the gross value of production in Punjab (Sombilla et al., 2002). Their excessively disproportionate use reflects their inefficient use, which engenders increased production costs with a corresponding decline in crop productivity (Kumar, 2003). The excessive use of chemicals has not only affected the $\mathrm{pH}$ level of soil and water; it also imposes adverse effects on human beings and animals (Government of Punjab, 2007; Thakur et al., 2008).

Furthermore, climate change has posed a severe threat to Punjab agriculture. The average rainfall in Punjab has declined considerably since the mid-1990s. Close observation of rainfall patterns also reveals a change in the distribution of rainfall during the year. The decline and changes in the distribution of rainfall can adversely affect the overall sustainability of agriculture. Apart from rainfall, abrupt changes in weather, increased temperatures in summer and winter, and sudden rains at the time of wheat maturity have strongly and adversely affected wheat yields.

Agricultural growth stagnation is evident from the fact that, whereas farm incomes grew at 7-8 percent per annum during the 1970s and 1980 s, that growth was less than two percent in later periods (Joshi, 2004). It seemed difficult to achieve further high growth rates with considerably higher levels of productivity in Punjab. However, interventions in the form of Rashtiya Krishi Vikas Yojana (RKVY) and many other efforts yielded encouraging results and helped to enhance agricultural 
growth in slow performing states such as Madhya Pradesh, Rajasthan, Chhattisgarh, and West Bengal. These trends helped in bridging the productivity gap in rice and wheat crops between Punjab and the allIndia level. Figure 8.8 reveals that the yield gap for rice and wheat at the all India level when compared to the Punjab state has declined considerably over time. Bridging the yield gaps has been considerable since the 1990s. That bridging resulted from higher growth in rice and wheat productivity in other states of India compared to that in Punjab state.

During 1998-99 to 2011-12, procurement of wheat from Madhya Pradesh increased by more than 15 times. Procurement from Rajasthan increased by more than three times. Procurement from other states increased almost sevenfold. As a result, the respective shares of Madhya Pradesh and Rajasthan rose from 2.1 percent to 13.7 percent, from 2.3 percent to 3.8 percent, and from 2.1 percent to 6.8 percent. The share of Punjab state in national wheat procurement declined by almost 16 percentage points during the last approximately 13 years. The share of Punjab also declined in rice procurement by more than 12 percentage points. Chhattisgarh, West Bengal, Orissa, and other states have emerged as important contributors to rice cultivation, with contributions of approximately 30 percent. An important implication of such a change in the relative performance of different states in terms of food productivity during the recent period is that Punjab's role in national food security is declining rapidly. Therefore, it is necessary to rethink Punjab's model of agriculture. Unsustainable practices must be urgently replaced by sustainable methods of cultivation that are also environmentally friendly.

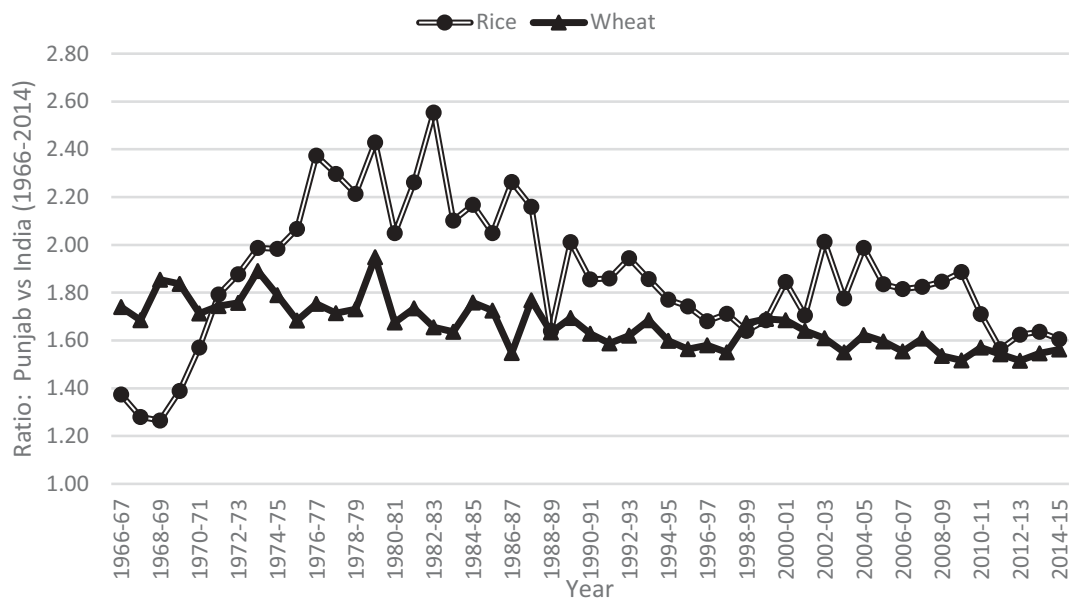

Figure 8.8 Trends in Productivity of Rice and Wheat: Punjab vs. India (1966-2014) Source: Government of India, Directorate of Economics and Statistics. 


\section{Kamal Vatta and Parisha Budhiraja}

\section{Options for agriculture sustainability in Punjab}

Marked negative effects arising from a continual increase in production and the dominance of rice-wheat monoculture in Punjab have caused the degradation of natural resources, especially overexploitation of groundwater reserves. As a consequence, they have threatened long-run agricultural sustainability. Climate change also poses a major challenge as extreme events are becoming more frequent. Appropriate steps must be devised to ensure long-term sustainability of agriculture to meet the demands of improving yields without compromising environmental integrity in the state of Punjab.

Past efforts at sustainability have emphasized crop diversification, enhanced water-use efficiency, and soil health improvement. These efforts aimed at ensuring long-term agricultural sustainability not only in terms of production and productivity, but also in terms of farming profitability and natural resource conservation. Several attempts have been undertaken to shift wide areas of cultivated land away from rice and wheat crops to higher value crops.

\subsection{Crop diversification}

Decreased crop diversity has not only caused a loss of biodiversity and degradation of natural resources. It has also led to an increased susceptibility to diseases and insect pests. Therefore, crop diversification is the clarion call in Punjab. To encourage crop diversification, the Johl Committee was instituted in 1986 and 2002. These committees explored the means for promoting productivity and growth in the state of Punjab. They also emphasized alternatives that use water efficiently, are ecologically compatible, and do not affect soil health. The committee recommended one million hectares to be replaced with alternative crops devoted to oilseeds and pulses. Additional areas under fruit, vegetable, and fodder cultivation can be farmed to supplement income-support measures. The Government of Punjab (2003) and Government of Punjab (2013) were formed to draft a policy for achieving faster and sustainable agricultural growth and to increase farmer incomes through enhanced productivity, reduction of production costs, adoption of high-value crops, and by encouraging agro-processing and dairy farming in the state. The draft policy was submitted to the Government of Punjab in March 2013.

Crop diversification can reduce actual agricultural water use by about 1.6 million ha m (Vatta et al., 2013). Diversification to high-value crops such as vegetables and fruits also plays a pivotal role in enhancing farmer incomes. However, the paradox is that despite concerns related to crop diversification, the area under rice cultivation increased rather than decreased. These efforts at crop diversification proved to be failures for multiple reasons. The lack of effective value chains for the alternative crops, especially fruits and vegetables, discouraged the farmers from diversification because the existing value chains are unable to ensure remunerative prices 
and price stability over a longer period of time, which was another prerequisite for the success of diversification efforts. Another important reason for the failure of the diversification efforts in the past might be the agricultural policy. In the past and even until recent times, the major emphasis of agricultural policy has been on enhancing food production and productivity, which ultimately translates into enhanced farm incomes. Few efforts on the policy front point to specific examination of resources or environmental conservation. The provision of free electricity to the farmers and a lack of efforts to curb the ever-increasing number of electricity operated tube wells go against the objective of reversing groundwater depletion. There is no cost of pumping out additional groundwater: power supplied to agriculture is free. Successful implementation of crop diversification efforts requires emphasis on efforts with a clear strategy related to contract farming, value chains, and production and marketing risks related to alternative crops.

Gill and Toor (2007) estimated that crop rotation with high-value alternatives to rice and wheat yields higher returns, leading to higher profits. Maize cultivation, in combination with those of onion and potato, provides returns to farmers around Rs.87,000 per ha compared to the cultivation of conventional rice and wheat combination with returns of Rs.47,000 per ha. Such cultivation also cuts water use by $97 \mathrm{~cm}$ per ha because of lower water requirements. Similarly, maize-wheat-moong, maize-potato-moong and groundnut-potato-fodder are more profitable and water-conserving crop combinations. Such multiple cropping systems also improve profitability and water conservation. Improvement in productivity of alternative crops, remunerative price policies for them, and assured procurement can help in achieving the desired level of crop diversification.

\subsection{Water conservation}

An important result of intensive agriculture in Punjab was faster depletion of groundwater resources. This rapid depletion increasingly gained importance because of emergence of water scarcity issue, which led to challenges in maintaining per-capita food production from irrigated land (Seckler et al., 1999). To overcome the reckless extraction of water resources, many water saving technologies and conservation practices might considerably improve water use efficiency.

Production of varieties with high water use efficiency and development, whether using biotechnology or conventional breeding, and of varieties with greater drought tolerance can be expected to contribute to increased yields in water-limited production environments (Charles, 2001; DeVries and Toenniessen, 2001). Many technologies and practices can reduce water use in agriculture and improve water-use efficiency, with more crop production per drop of water, and with no adverse impact on farmer incomes. These technologies, with their potential water savings, can affect crop yields. For instance, a laser leveler can reduce water use by $36.19 \mathrm{~cm}$ and improve crop 


\section{Kamal Vatta and Parisha Budhiraja}

yields by 0.78 tons/ha. The water savings translate to reduction in electricity consumption by $213.35 \mathrm{kWh} / \mathrm{ha}$, with corresponding cost savings of Rs.1,022/ha (Sidhu et al., 2007). Because laser leveling has been adopted widely in Punjab, these benefits translate into huge savings in power subsidies as well as increasing farmer incomes.

Apart from laser leveling, planting on permanent beds is a technique that saves $60 \mathrm{~cm} / \mathrm{ha}$ of water in rice cultivation and $8 \mathrm{~cm} / \mathrm{ha}$ or water in wheat cultivation compared to conventional methods of planting and sowing. The resultant water electricity savings in rice and wheat are, respectively, 353.72 $\mathrm{kWh} / \mathrm{ha}$ and $47.16 \mathrm{kWh} / \mathrm{ha}$ (Dhaliwal et al., 2008). Aside from this, using zero tillage (with a happy seeder ${ }^{3}$ ) helps to conserve rice stubble in the soil to improve organic matter and soil fertility. It also reduces air pollution caused by the burning of paddy straw, conserves water by creating straw mulch, and lowers tillage costs. The technique reportedly reduces water use for wheat crops by $8.5 \mathrm{~cm} / \mathrm{ha}$, with a corresponding electricity saving of $50.11 \mathrm{kWh} / \mathrm{ha}$ and power cost by Rs.240/ha (Singh et al., 2008). A tensiometer is another device that enhances water use efficiency. Experimental evidence has established water savings of $37 \mathrm{~cm} / \mathrm{ha}$ achieved using a tensiometer, with corresponding power savings of $218.13 \mathrm{kWh} / \mathrm{ha}$ and reduction in power costs by Rs.1,045/ha (Singh et al., 2006). Seeding rice is estimated directly as reducing rice water requirements by about $45 \mathrm{~cm}$ per ha with a corresponding power saving of $265.29 \mathrm{kWh} / \mathrm{ha}$ and cost reduction of Rs.1,271/ha. Apart from this, such technologies decrease salinization and water-logging problems.

\subsection{Soil health management}

During the four decades extending approximately from 1960 through 1995, the use of fertilizers has increased many times. It is likely to rise even more in future years. However, further increased use of fertilizers is expected to impose double injury to the land. It is unlikely to be effective in producing larger yields because of diminishing returns; moreover, it will render the soil unfit for future cultivations. Therefore, we require increased nutrient use efficiency, i.e., additional units of cereal production per unit of nitrogen, phosphorus, and water added. A variety of improvements can contribute to increased efficiency. For example, in the United States, fertilizer efficiency has increased by 36 percent for maize over the last 21 years as a result of large investments in public sector research and extension education, and investment by farmers in soil testing and improved timing of fertilizer application (Frink et al., 1999; Cassman et al., 2002). Therefore, reaching numerous farmers is necessary for capacity building, promoting the efficient use of inputs, sustainable technologies, and practices. Because many farmers in Punjab are connected through mobile phones, central agencies and the state agricultural university can guide and assist farmers with application timing and input quantities. 
Fertile soils with good physical properties are fundamentally important for sustainable agriculture. Therefore, micro-nutrient deficiencies have led to a decline in crop production and productivity. The adoption of various soil health management practices can improve soil health. Soil-testing based application of fertilizers can help to reduce fertilizer use and thereby improve productivity. The testing of soils before crop sowing helps to estimate the actual availability of nutrients available in the soils and facilitates accurate doses of fertilizers. Just about 4 percent of farmers apply fertilizers based on soil-testing reports. The rest opt for blanket application without considering variation in soil and crop types. The Draft Agricultural Policy for Punjab of 2013 emphasizes the strengthening of the soil testing infrastructure in the state. In addition, increased awareness among farmers about the benefits of fertilizer application based on soil testing will help in balancing fertilizer use and eliminating macro-nutrient and micro-nutrient deficiency. Some other methods might prove useful, such as widened use of organic manures, and split application of nitrogen fertilizers.

Another important aspect is the timely application of fertilizers to crops. A leaf color chart (LCC) is an extremely simple instrument showing different color shades ranging from yellowish green to dark green, resembling the leaf color of the crop at different stages of nitrate availability. Periodic matching of the leaf shades with the shades of the LCC helps in choosing correct times for fertilizer application. The use of leaf color charts for rice can lead to conservation of about 26 percent of the nitrogenous fertilizers with no adverse effect on rice productivity (Singh et al., 2006). Some other methods of improving soil health and fertility include the wider use of organic manures, split application of nitrogenous fertilizers, and selection of optimal combinations of fertilizers for various nutrients. It is noteworthy that the issue of soil health can be addressed easily by encouraging the above practices of soil-health management.

\subsection{Organic farming}

The principal goal of organic farming is the development of productive enterprises that are sustainable and harmonious with the environment (PSFC, 2008). Reliance on organic nutrient sources optimizes productivity and raises input efficiency. The major objective of the organic agriculture is to produce sufficient quantities of better quality food by promoting synergies between different components of the ecosystem to improve ecosystem health with minimum pollution of all forms (Pandey and Singh, 2012). Organic farming, being agrochemical free, helps to reduce the use of industrially produced and commercially distributed agrochemicals for agriculture and to improve soil health through the increased use of organic manures. Organically produced foods command higher prices and provide incentives for the adoption of such practices, but the reduction in yields is an important issue. In actuality, many reports have described considerable reductions 
in crop yields. Pandey and Singh (2012) report 10-15 percent lower yields in organic farming compared to conventional farming practices, although Singh and Grover (2011) estimated yields as higher than 35 percent.

Nowadays, precision agriculture is also practiced when managing crop production inputs in an environmentally friendly manner. Agriculture of this kind can contribute in many ways to the long-term sustainability of production agriculture, confirming the intuitive idea that fertilizers and pesticides should be applied only where they are needed and should impose minimal environmental loads. It is a beneficial environment because the targeted use of inputs reduces losses from excess application. Averting nutrient imbalances, weed escape, insect damage, etc. brings other benefits for crop cultivation. The need exists to generate awareness among farmers to use inputs rationally without disturbing the economics of cultivation. However, a salient concern is that the areas under organic farming cultivation in India have progressed at an extremely slow pace (Narayanan and Narayanan, 2005). More research and development efforts must be directed to organic farming to produce a clear roadmap for future policy.

In states such as Punjab, more than 90 percent of the rice cultivation area is harvested with combine harvester, which leaves fields with the stubble standing in the field. This stubble is subsequently burnt, causing loss of nutrients, organic matter, and soil microbes and exacerbating health-related problems. However, if the residue is managed well, then the nutrients in the soil are replenished, thereby increasing physical properties and reducing water demand. To mitigate this difficulty, happy seeders, rice straw choppers, straw balers, and biogas plants can reduce the incidence of burning. Research experiment results indicate that rice stubble retention adds nutrients to the soil and that it reduces nitrogen requirements of wheat crops by 10 percent $(26.5 \mathrm{~kg}$ of urea/ha) in the fifth year of stubble retention and 15 percent $(40 \mathrm{~kg}$ of urea/ha) from the tenth year onward. Losses to the tune of 63 thousand tons of nitrogen and 37 thousand tons of potassium by burning can be avoided by adopting crop residue management for rice cultivation areas (Singh et al., 2008).

These techniques, changing cropping patterns by diversification along with soil management, reduce water stress with no adverse effect on farmer incomes. With the adoption of crop diversification along with water-saving practices, a scenario has been developed to gauge the returns from improved technologies. One target is that 50 percent of the area be laser leveled, with 10 percent of the area under rice coming under direct seeding, with an equal area irrigated while using tensiometers. In addition, 10 percent of the wheat is assumed to be sown using zero tillage technology. The potential water savings from these technologies and practices are presented in Table 8.3.

The successful adoption of technologies and practices under this scenario will engender further savings of 726.95 thousand ha $\mathrm{m}$ of water. This combined technique can save 2.3 million ha $\mathrm{m}$ of water used now for Punjab 
Table 8.3 Effects of Water Conservation Technologies and Practices on Water Use

\begin{tabular}{lll}
\hline Crop & $\begin{array}{l}\text { Water saving } \\
(\mathrm{mm})\end{array}$ & $\begin{array}{l}\text { Total water saving } \\
\text { potential } \\
\text { (thousand ha m) }\end{array}$ \\
\hline Laser leveling of fields & 360 & 504.00 \\
Direct seeding of rice & 450 & 126.00 \\
Use of tensiometers for rice production & 85 & 67.20 \\
Sowing of wheat with zero tillage & $240^{*}$ & 29.75 \\
Water savings from technologies and practices & & 726.95 \\
Water savings from crop diversification & & 1575.00 \\
Total water savings with crop diversification and & & 2301.95 \\
water saving practices. & \\
\hline
\end{tabular}

Note: Negative values denote the decline in farm income as a result of diversification to include these crops. *Means that the water savings have been calculated here @ 15 percent of 1,600 mm, based on the field experiments.

agriculture. Under this scenario, a policy to divert 1.2 million ha area from rice cultivation to other crops might reduce it to 0.55 million ha. Therefore, not 1.6 million ha of rice cultivation but 2.15 million ha might be cultivated without endangering groundwater sustainability in the long run.

\section{Conclusion}

With the advent of the Green Revolution, India became food self-sufficient. Nevertheless, the first wave of this technological change was confined largely to the wheat crop and to northern India, especially Punjab, resulting in a limited contribution to overall national economic development. Furthermore, the exorbitant use of resources, for instance, groundwater extraction to irrigate high yielding varieties and increased use of inputs like fertilizers and agro-chemicals, resulted in a slowdown in the agricultural sector from the mid-1990s. Owing to over-dependence on groundwater sources for irrigation, a severe disequilibrium between demand and supply of water occurred in agriculture. The increase in total cropped area (reflected by the parallel increase in cropping intensity) and dominance of paddy in the cropping pattern are responsible for this imbalance. As a result, the water table has plummeted in central Punjab. Most blocks are categorized today as "dark" regions. The inefficient utilization of water, including flooding methods of irrigation, is attributable to the free availability of water. The provision of free electricity has exacerbated this wasteful use of water. Dependence on groundwater has increased further because a marked decline in rainfall has occurred over time, which may intensify the electricity consumption in future. Furthermore, climate change may pose an additional 
challenge, with an increase of extreme climatic events having grievous implications for the productivity of the ecosystem.

Therefore, in the context of securing the nation's food security, sustainable agriculture has assumed a greater importance in recent years in order to meet the challenges faced by the production system. Many farming technologies and practices have been devised, aimed at using resources judiciously, reducing dependence on fertilizers and agro-chemicals, and restoring diversity in cultivation patterns. Water-saving technologies and practices such as laser leveling, the use of tensiometers in rice, direct seeding of rice, and sowing of wheat with happy seeders can bring marked reduction in water use in agriculture. The Act to prohibit early transplantation of rice also contributed considerably to the mitigation of groundwater depletion. Soil-testing based fertilizer application, use of leaf color charts, and other methods can support effective soil health management.

To summarize briefly, tradeoffs and synergies exist between food production and the environment. The need exists for infrastructural and institutional support for the adoption of conservation technologies and practices. Financial support, development of effective contract farming models, and innovations for building economically viable value chains are expected to pave the way to rapid and successful crop diversification. It is necessary to attune the agricultural policy in the state, so that it cannot only increase food production to ensure food security while increasing farm incomes, but also encourage the sustainable use of natural resources.

\section{Notes}

1 Minimum Support Price is a form of market intervention by the Government of India to insure farmers against a sharp fall in farm prices during bumper production years. Based on recommendations from CACP, the Government announces MSP at the beginning of the sowing season for certain crops.

2 There are four categories: 'safe' areas have groundwater potential for development; in 'semi-critical' areas, cautious groundwater development is recommended; in 'critical' areas and 'overexploited' areas should have intensive monitoring and evaluation and future ground development linked with water conservation measures.

3 Happy seeder is a unique technique which without burning crop (rice) residue, cuts and lifts rice straw, sowing wheat into the soil. This technology is environmentally friendly, and it saves water.

\section{References}

Cassman, K. G., A. Dobermann, and D. T. Walters (2002). "Agroecosystems, Nitrogen-Use Efficiency, and Nitrogen Management," AMBIO: A Journal of the Human Environment, vol. 31(2), pp. 132-40.

Chadha, G. K. (1986). The State and Rural Economic Transformation: The Case of Punjab 1950-85, New Delhi: Sage Publications.

Chand, R., P. Kumar, and S. Kumar (2011). "Total Factor Productivity and Contribution of Research Investment to Agricultural Growth in India,” Policy Paper 25, 
New Delhi, India: National Centre for Agricultural Economics and Policy Research.

Charles, D. (2001). "Seeds of Discontent," Science, vol. 294, pp. 772-75.

Chengappa, R. (1989). “Agriculture: A Golden Revival,” India Today, New Delhi, pp. 78-83.

CSO (Central Statistical Organization) (1988). New Series on National Accounts with 1980-81 as Base Year, 1980-81 to 1985-86, New Delhi: Government of India.

CSO (Central Statistical Organization) (1989a). National Accounts Statistics, 1980-81 to 1986-87, New Delhi: Government of India.

CSO (Central Statistical Organization) (1989b). National Accounts Statistics, (New Series) 195051 197. http://mospi.nic.in/sites/default/files/publication_reports/fac tor20income20198020base_5aug08_final.pdf.

Dev, S. M. and A. N. Sharma (2010). Food Security in India: Performance, Challenges and Policies, Oxfam India Working Paper Series (OIWPS-VII), New Delhi: Oxfam India.

DeVries, J. and G. H. Toenniessen (2001). Securing the Harvest: Biotechnology, Breeding, and Seed Systems for African Crops, Wallingford: CABI Publishing.

Dhaliwal, H. S., R. P. Singh, T. Singh, Y. Singh, E. Humphreys, and S. S. Kukal (2008). "A Financial Analysis of Permanent Raised Beds for Rice-Wheat and Alternative Cropping Systems in Punjab, India,” In Humphreys, E. and Roth, C. H. eds., Permanent Beds and Rice-residue Management for Rice-Wheat Systems in the IndoGangetic Plain, ACIAR Proceedings No. 127, Canberra, Australia: Australian Centre for International Agricultural Research., pp. 79-91.

Frink, C. R., P. E. Waggoner, and J. H. Ausubel (1999). "Nitrogen Fertilizer: Retrospect and Prospect," Proceedings of the National Academy of Sciences, vol. 96(4), pp. $1175-80$.

Ghuman, R. S., I. Singh, and L. Singh (2007). Status of Local Agricultural Labour in Punjab, Mohali: The Punjab State Farmers Commission, Government of Punjab.

Gill, M. S. and M. S. Toor (2007). Farming System Approach Towards Income Enhancement, ICAR Project Report, Ludhiana, India: Department of Agronomy, Agro-Meteorology and Forestry, Punjab Agricultural University.

Gill, S. S. (1994). "The Farmers' Movement and Agrarian Change in the Green Revolution Belt of North-West India," The Journal of Peasant Studies, vol. 21(3\&4), pp. 195-211.

Glaeser, B. (1987). "Agriculture between the Green Revolution and Ecodevelopment: Which Way to Go?," In Glaeser, B. ed., The Green Revolution Revisited: Critique and Alternatives, London and New York: Routledge, pp. 1-7.

Government of Punjab (1970-2015). The Statistical Abstract of Punjab, Various Issues, Punjab, Chandigarh: Economic Adviser to Government of Punjab, Economic and Statistical Division.

Government of Punjab (2003). Report of the Expert Committee on the World Trade Organisation for Punjab, Y. K. Alagh Committee Report, Chandigarh: Institute of Development and Communication (1DC).

Government of Punjab (2005). Central Groundwater Board, Punjab Chandigarh. http://cgwb.gov.in/gw_profiles/st_Punjab.htm.

Government of Punjab (2007). State of Environment in Punjab, Agriculture and Environment, Chandigarh: Punjab State Council of Science and Technology.

Government of Punjab (2013). Draft Agriculture Policy for Punjab, Chandigarh: Committee for Formulation of Agriculture Policy for Punjab State, Government of Punjab. 
Hira, G. S. (2009). "Water Management in Northern States and the Food Security of India," Journal of Crop Improvement, vol. 23(2), pp. 136-57.

Ittyerah, A. C. (2013). "Food Security in India: Issues and Suggestions for Effectiveness," Theme Paper for 55th Members' Annual Conference, Indian Institute of Public Administration, New Delhi.

Johl, S. S., R. S. Sidhu, and K. Vatta (2014). "Natural Resources Management in Punjab Agriculture: Challenges and Way Forward," Working Paper, Centers for International Project Trust, New Delhi.

Joshi, A. (2004). "Farm Household Income, Investment and Consumption," Economic and Political Weekly, vol. 39(4), pp. 321-23.

Kumar, M. D. (2003). Food Security and Sustainable Agriculture in India: The Water Management Challenge, Working Paper No. 60, Sri Lanka: International Water Management Institute.

Narayanan, S. and S. Narayanan (2005). Organic Farming in India: Relevance, Problems and Constraints, Mumbai: National Bank for Agriculture and Rural Development.

Pandey, J. and A. Singh (2012). "Opportunities and Constraints in Organic Farming: An Indian Perspective," Journal of Scientific Research, vol. 56, pp. 47-72.

Parayil, G. (1992). "The Green Revolution in India: A Case Study of Technological Change," Technology and Culture, vol. 33(4), pp. 737-56.

PSFC (2008). Organic Farming: Its Necessity. How Far Can It Go? Mohali: The Punjab State Farmers Commission, Government of Punjab.

Ramakrishnan, P. S. (2008). Ecology and Sustainable Development: Working with Knowledge System, New Delhi: National Book Trust.

Rao, J. M. (1998). "Food, Agriculture and Reforms: Change and Continuity," Economic and Political Weekly, vol. 33(29\&30), pp. 1955-60.

Rath, N. and V. S. Patvardhan (1967). Impact of Assistance under PL 480 on Indian Economy, Gokhale Institutes Studies No. 48, Poona: Gokhale Institute of Politics and Economics.

Repetto, R. (1994). The "Second India" Revisited: Population Growth, Poverty, and Environment over Two Decades, Washington, DC: World Resources Institute.

Seckler, D., B. Randolph, and U. Amarasinghe (1999). "Water Scarcity in the Twenty-First Century," International Journal of Water Resources Development, vol. 15(1\&2), pp. 29-42.

Sidhu, H. S., J. S. Mahal, I. S. Dhlaiwal, V. Bector, M. Singh, A. Sharda, and T. Singh (2007). Laser Land Levelling: A Boon for Sustaining Punjab Agriculture, Farm Machinery Bulletin, Ludhiana: Department of Farm Power and Machinery, Punjab Agricultural University.

Singh, C. B., I. M. Chhibba, and J. S. Brar (2006). Technologies for Efficient Management of Soil, Water and Nutrients in Punjab, Technical Bulletin 1, Niche Area of Excellence, Ludhiana, India: Department of Soils, Punjab Agricultural University.

Singh, I. P. and D. K. Grover (2011). "Economic Viability of Organic Farming: An Empirical Experience of Wheat Cultivation in Punjab," Agricultural Economics Research Review, vol. 24(2), pp. 275-81.

Singh, K. and S. Kalra (2002). "Systems, Varietal Diversity, Growth and Sustainability of Rice Production in Punjab," Economic and Political Weekly, vol. 37(30), pp. 3139-48. 
Singh, K., P. S. Rangi, and S. Kalra (2004). "Wheat Production and Sustainability in Punjab: Growth and Varietal Diversity," Indian Journal of Agricultural Economics, vol. 59(4), p. 745.

Singh, R. P., H. S. Dhaliwal, E. Humphreys, H. S. Sidhu, M. Singh, Y. Singh, and M. Blackwell (2008). Economic Assessment of the Happy Seeder for Rice-Wheat Systems in Punjab, India. Paper presented at the 52nd Annual Conference, Canberra, ACT, Australia.

Sombilla, M., M. Hossain, and B. Hardy (2002). "A Long-term Outlook of Rice Supply and Demand Balances in South, Southeast and East Asia," In Sombilla, M., Hossain, M. and Hardy, B. eds., Developments in the Asian Rice Economy, Los Banos: International Rice Research Institute, pp. 291-316.

Thakur, J. S., B. T. Rao, A. Rajwanshi, H. K. Parwana, and R. Kumar (2008). "Epidemiological Study of High Cancer among Rural Agricultural Community of Punjab in Northern India," International Journal of Environmental Research and Public Health, vol. 5(5), pp. 399-407.

Vatta, K., M. S. Sidhu, and A. Kaur (2013). Food Production and Natural Resources in Punjab: Trade off and Synergies, Ludhiana, India: Draft report submitted to United Nations Environment Programme (UNEP), Punjab Agricultural University.

World Bank (2008) World Development Report: Agriculture for Development, Washington, DC: World Bank.

Zarkovic, M. (1987). Issues in Indian Agricultural Development, Boulder, CO: Westview Press. 


\title{
9 The nitrogen cycle and fertilizer subsidy in India
}

\author{
Ippei Sekido
}

PROJECT RESEARCHER AT THE INSTITUTE FOR ADVANCED GLOBAL STUDIES, GRADUATE SCHOOL OF ARTS AND SCIENCES, THE UNIVERSITY OF TOKYO, JAPAN

\section{Introduction}

This chapter is an attempt to investigate the issue of sustainability in food production in India from the viewpoint of chemical fertilizers, especially nitrogen fertilizer. In particular, we try to clarify the effects of the government provided fertilizer subsidy on the nitrogen cycle. The analysis also addresses not only nitrogen fertilizer but also phosphorus and potassium (P \& K) fertilizers. An important task of the paper is to ascertain whether or not any possibility exists of improving nitrogen efficiency by reforming the fertilizer subsidy system. The demographic dynamics and per-capita cereal consumption are also examined in relation to fertilizer subsidies.

The issue of fertilizers is closely related to the problem of sustainable agricultural development and the issue of the 'food-water-energy nexus,' the major target of this book as a whole, mainly for the following three reasons. First, there is no doubt that chemical fertilizers are a fundamentally important input to increase cereal production. Along with a stable water supply, fertilizers have contributed to the growth of cereal yields. In order to help increase food production, huge amounts of subsidies have been given to fertilizers by the government of India. Second, the incremented subsidies to fertilizers, however, have become a heavy burden on the budget of the central government. As chapter 7 of this book volume argues, the state governments have faced serious fiscal deficits mainly caused by the agricultural electricity subsidy. Although born by different governments (central vs. state), the amount of fertilizer subsidy, especially for nitrogen fertilizer, has been increasing and is as important as the electricity subsidy. ${ }^{1}$ Both subsidies are intrinsically connected. The issue of fertilizer subsidy affects the issue of the 'foodwater-energy nexus,' by competing in scarce fiscal resources of the government. Third, the intensive use of nitrogen fertilizer has led to a further problem: the deterioration of the water environment. When not fully absorbed by the crops, the nitrogen discharged from farmland flows into groundwater and rivers, causing severe environmental pollution. In fact, the growing problem of contaminated ground- and river water is currently posing severe difficulties in India and will continue to do so. By investigating the nitrogen cycle and 
by evaluating its effects on the environment using a nitrogen flow model, Shindo (2012) revealed that the nitrogen fertilizer input is the greatest factor exacerbating the nitrogen balance of farmland.

The composition of the following chapter is as follows. Section 2 describes the transformation of the fertilizer subsidy system in India, as analyzed in conjunction with trends in NPK fertilizer input, the prices of NPK fertilizers, and changes in cereal production. The effects of changes in the fertilizer subsidy systems on the use of NPK fertilizers and their prices are clarified. The relationship between changes in the fertilizer subsidy system and cereal production will also be investigated. Section 3 then explores the environmental effects of using the nitrogen flow model of the nitrogen cycle in India, especially in comparison with China, and the effects of increased nitrogen fertilizer inputs. Section 4 presents a discussion of fertilizer policies that have the potential to improve nitrogen efficiency and nutritional balance in the soil. Finally, in section 5, future Indian population dynamics and per-capita food demands will be analyzed in order to advance alternative policies.

\section{Fertilizer subsidy}

The fertilizer subsidy has been used as a policy instrument to stabilize and increase crop production and the domestic food supply. To encourage investment in the fertilizer industry, the government of India allocated subsidies to both domestic manufacturers and importers of fertilizer to mitigate the substantial gap that separates production costs and sales prices. Because poor production efficiency and the resultant high production costs pushed up retail prices, the government had to intervene in the market to keep fertilizer prices low. Otherwise farmers would be prevented from employing them sufficiently, engendering unstable and insufficient crop production and supply. Because of this structural obstacle, the amounts of subsidies had to be greatly increased (Figure 9.1). This enlarged financial burden, however, forcing the government to repeatedly reform the subsidy system. Some reforms were implemented in the following manner.

In 1977, the Retention Price Scheme (RPS) was introduced. It was aimed at achieving not only self-sufficiency of urea (nitrogen fertilizer) production, but also of cereal production. The scheme was expanded successively from 1979 to encompass other composite fertilizers including P \& K fertilizers. The retention price was calculated by summing up all costs: raw materials, salaries, insurance, maintenance, depreciation, capital related charges, selling expenses, etc. Then certain profits were added for every production plant. However, the retail prices of fertilizers for farmers were kept low. The scheme generated increased investment in the fertilizer industry. However, no incentives were given to improve fertilizer production efficiency. Therefore, fertilizer subsidies also had to increase. Subsidy system reform has been required numerous times because of pressure on government finances. 


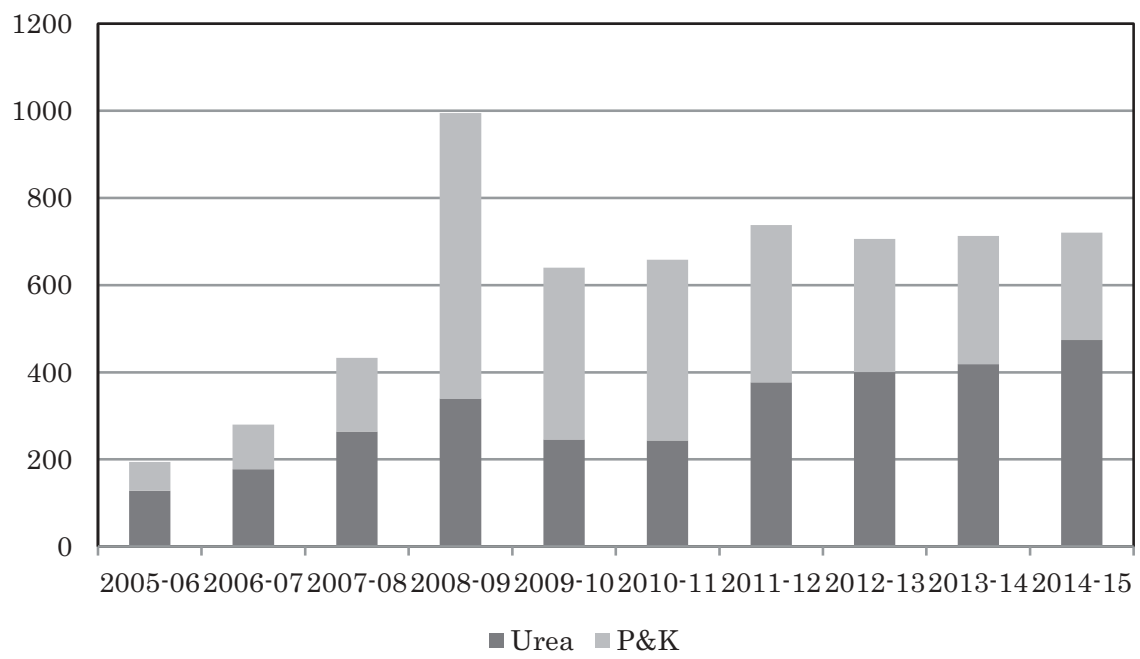

Figure 9.1 Fertilizer Subsidy

Source: Department of Fertilizers, Ministry of Chemicals \& Fertilizers, Government of India.

The implemented reforms differed in their focus between nitrogen fertilizers and $\mathrm{P} \& \mathrm{~K}$ fertilizers. The institutional reforms that tried to reduce subsidies for urea specifically emphasized improving the efficiency of production plants. The New Pricing Scheme (NPS) was introduced in 2003 to replace the RPS. The main purpose was not to reduce the prices paid to the production plants, but to increase their production efficiency by providing incentives. Whereas the RPS was determined by the production cost of each plant, existing plants in the NPS were classified into five categories according to raw materials (gas-based, naphtha-based, fuel oil/low-sulfur heavy stock based, etc.). Then the fixed rates were announced for each group. This scheme encouraged the usage of more efficient feedstocks and the most advanced technology. It was therefore aimed at raising the efficiency of production to an international standard. However, raising the retail prices for consumers (farmers) was avoided to the greatest extent possible. The government increased the retail price of urea from Rs.2,350 to Rs.4,600 per ton during 1990-2000. Since then, however, the government has avoided further increases. Compared with the case of $\mathrm{P} \& \mathrm{~K}$ fertilizers, the rate of increase of urea retail prices was much lower (Figure 9.2). Even when the Expenditure Reforms Commission recommended that the government increase the urea price by 7 percent every year from 2001, no such action was actually implemented. The government regarded urea fertilizer as the most important fertilizer and continued avoiding increasing its price for fear of 


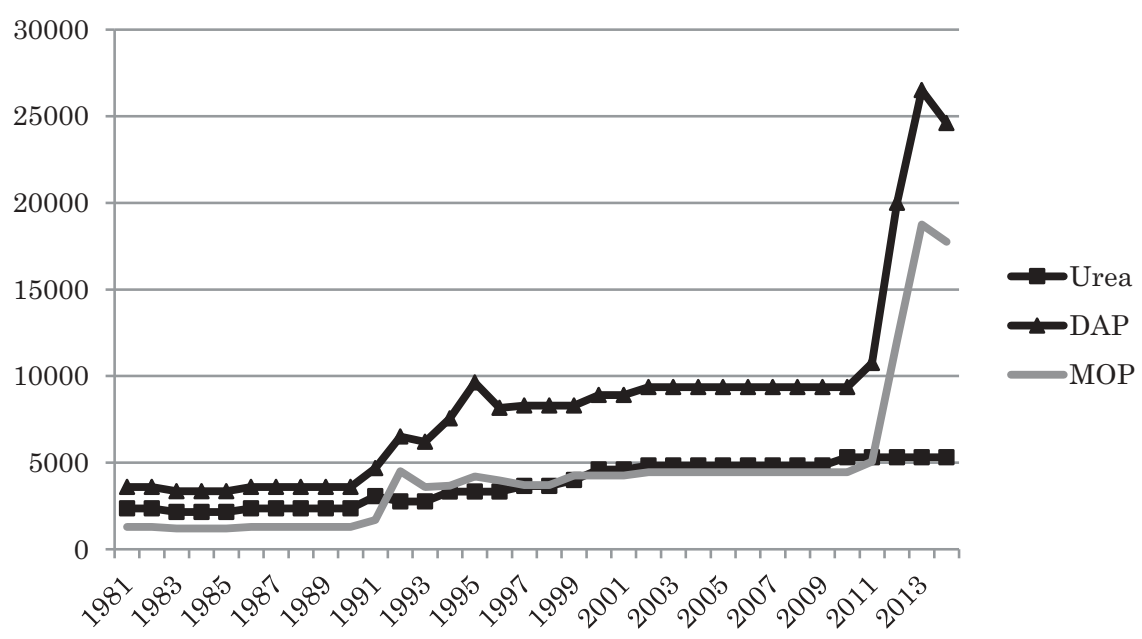

Figure 9.2 Price of Fertilizers (urea, DAP, MOP)

Source: Department of Fertilizers, Ministry of Chemicals \& Fertilizers, Government of India.

decreased consumption. In addition, farmers strongly opposed the priceraising policies when planned. As a result of this price freezing policy, the growing burdens caused by subsidies have persisted to the present day.

Retail prices of $\mathrm{P} \& \mathrm{~K}$ fertilizers have risen significantly several times. In 1992, control of the RPS was abolished for P \& K fertilizers. Because the RPS was continued for the nitrogen fertilizer, the retail prices of $\mathrm{P} \&$ $\mathrm{K}$ fertilizers became high. Fearing the decline of consumption of $\mathrm{P} \&$ $\mathrm{K}$ fertilizers because of the price hike, the government announced an ad hoc concession (subsidy) of Rs.1,000 per MT for P \& K fertilizers to mitigate the price increase effects. However, the price of the most popular P \& $\mathrm{K}$ fertilizers, di-ammonium phosphate (DAP) and murate of potash (MOP), continued to increase 2.7 times and 3.6 times respectively during 1991-1995. To counteract those price movements, the Department of Agriculture and Cooperation started indicating a uniform Maximum Retail Price (MRP) for DAP and MOP in 1997. Under this scheme, the difference between the delivered price of fertilizers and the MRP was compensated by the government as a subsidy for both manufacturers and importers. As a result of its implementation, the subsidy for $\mathrm{P} \&$ $\mathrm{K}$ fertilizers increased explosively from 2008 (Figure 9.1). To make matters worse, an increase in international prices for fertilizer ensued, including its raw materials and energy costs. Actually, P \& K fertilizers were especially susceptible to the international price fluctuations because they depended heavily on imports. In addition, a decline in the marginal response of food 
production to additional fertilizer input was observed in the last few years of this scheme. In 2010, a new scheme called the Nutrient Based Subsidy (NBS) for P \& $\mathrm{K}$ fertilizers was announced. Under this scheme, the subsidy is determined based on the nutrient contents of fertilizers, unlike the former product-based subsidy system. This was intended to combat the sharp increase in the government fiscal burden and to encourage a balanced application of nutrients. In addition, to increase competition among the fertilizer companies and to distribute various types of fertilizer to the market at available prices, they were allowed to fix the MRP at 'reasonable' prices independently. To ensure the rationality of the prices, all the fertilizer companies were obliged to submit their cost data to the Department of Fertilizers: for cases in which unreasonable MRP were observed, the subsidy might be restricted. Nevertheless, the price of $\mathrm{P} \&$ $\mathrm{K}$ fertilizers grew considerably, not only because of the high international prices of raw materials and fertilizers, but also because of the difficulty in checking and monitoring the rationality of the MRP fixed by the companies. The NBS does not seem to stimulate competition among fertilizer companies. The increased prices of $\mathrm{P} \& \mathrm{~K}$ fertilizers led to a decline in consumption. As a result, the subsidy for $\mathrm{P} \& \mathrm{~K}$ fertilizers decreased after the start of the NBS. Nevertheless, the total fertilizer subsidy has not changed because of the increased subsidy for urea fertilizer.

Changes in fertilizer consumption and cereal production in India are depicted in Figures 9.3 and 9.4. Whenever the fertilizer subsidy system was revised, fertilizer consumption was significantly transformed. The consumption of nitrogen fertilizer continued to steadily rise because of control over retail prices. However, the P \& K fertilizer price has increased since all P \& K fertilizers under RPS were decontrolled in 1992, and their consumption has declined considerably. Moreover, after the introduction of the NBS in 2010, P \& K fertilizer experienced a marked price increase again, along with a concomitant decrease in their consumption.

Changes in cereal production during the examined period attracted our attention. Despite the marked decrease in $\mathrm{P} \& \mathrm{~K}$ fertilizer consumption during 1992-2011, cereal production increased. In particular, the total production of rice, wheat, and maize increased by 13 percent between 2010 and 2013 despite a 40 percent decrease in the total consumption of $\mathrm{P} \&$ $\mathrm{K}$ fertilizer. From this fact, we infer that the short term (two to three years) change in $\mathrm{P} \& \mathrm{~K}$ fertilizer consumption does not affect cereal production. A strong correlation exists between the consumption of nitrogen fertilizer and cereal production. Although it is difficult to deny that the response of cereal production to nitrogen fertilizer input has deteriorated in recent years, it is evident that nitrogen fertilizer among all fertilizers plays the most important role in cereal production.

It is noteworthy that both nitrogen fertilizer consumption and rice and wheat production have not increased since 2010. This lack of increase might be a reflection of the stagnation of domestic demand for rice and wheat. 


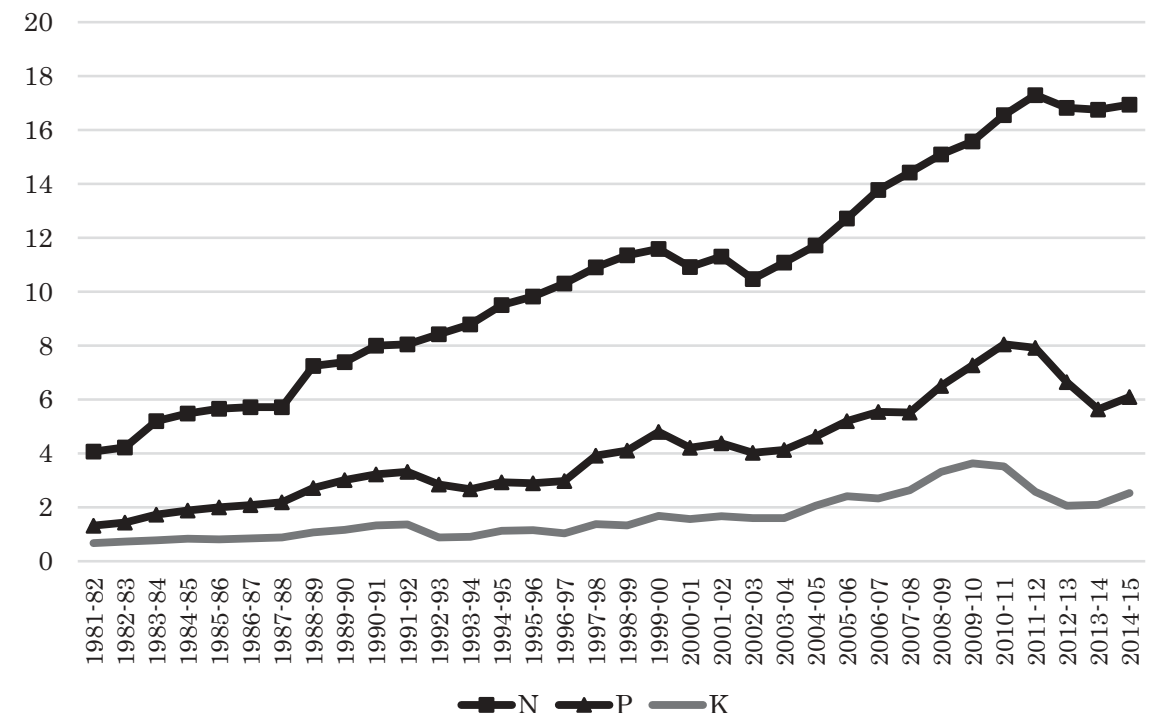

Figure 9.3 Fertilizer Consumption

Source: Department of Agriculture, Cooperation and Farmers Welfare, Ministry of Agriculture and Farmers Welfare, Government of India, 2016.

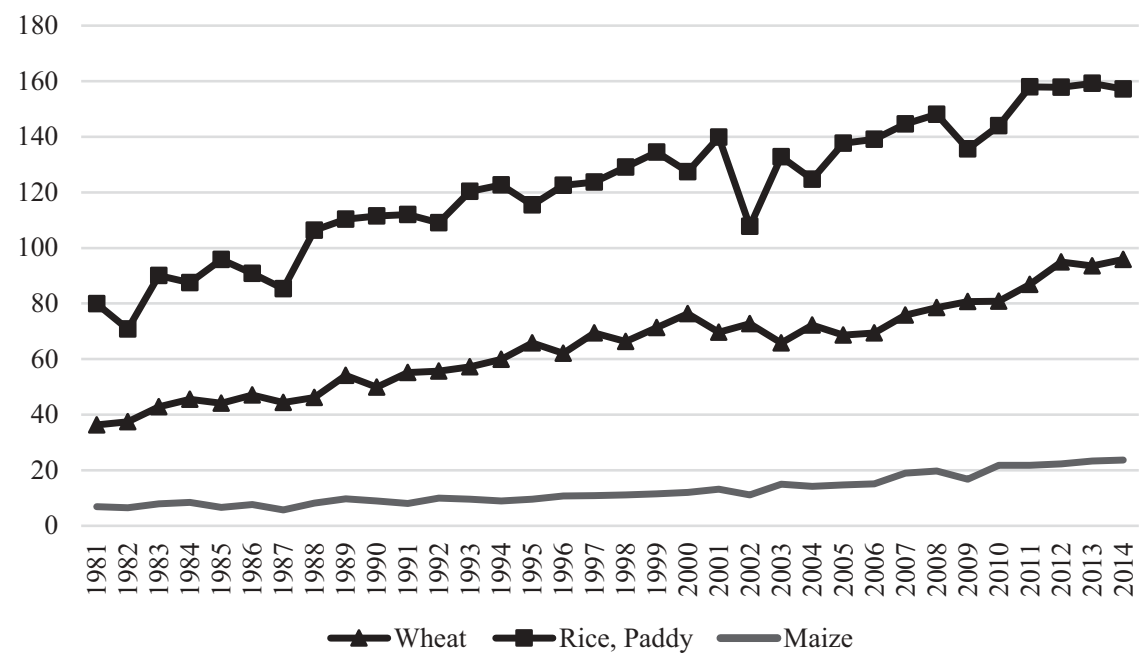

Figure 9.4 Cereal Production

Source: Department of Agriculture, Cooperation and Farmers Welfare, Ministry of Agriculture and Farmers Welfare, Government of India, 2016. 
Details are analyzed in Section 5, which explains that cereal consumption will not continue to increase, a factor which might affect future supply and demand related to fertilizer.

\section{Characteristics of nitrogen flow in India}

\subsection{Nitrogen flow model}

Shindo (2012) estimated changes in the nitrogen balance in agriculture for 13 Asian countries using the nitrogen flow model presented in Figure 9.5. Nitrogen is brought into this system by the importation of food, fish, fertilizer, and nitrogen fixation. It circulates into the system through humans, crops, and livestock. With regard to farmland, nitrogen inflows into farmland from fertilizer, nitrogen fixation, and livestock, but nitrogen outflows from farmland to crops, atmosphere via ammonia volatilization, and groundwater or rivers. The nitrogen discharged from farmland to groundwater and/or rivers is a factor causing various types of environmental pollution including groundwater pollution, eutrophication of rivers and wetlands, and outbreaks of red tide. For these reasons, estimating the nitrogen cycle is a helpful method to assess the environmental pollution attributable to food production.

The characteristic features of nitrogen flow in India vis-à-vis China can be clarified using the same model. The latest FAOSTAT, USDA (United States Department of Agriculture), and NSS (National Sample Survey) data can be used for estimation. Figure 9.6 presents the results. In both countries, nitrogen fertilizers produce the largest flow among all flows. Both countries must input vast quantities of nitrogen fertilizers to feed their huge

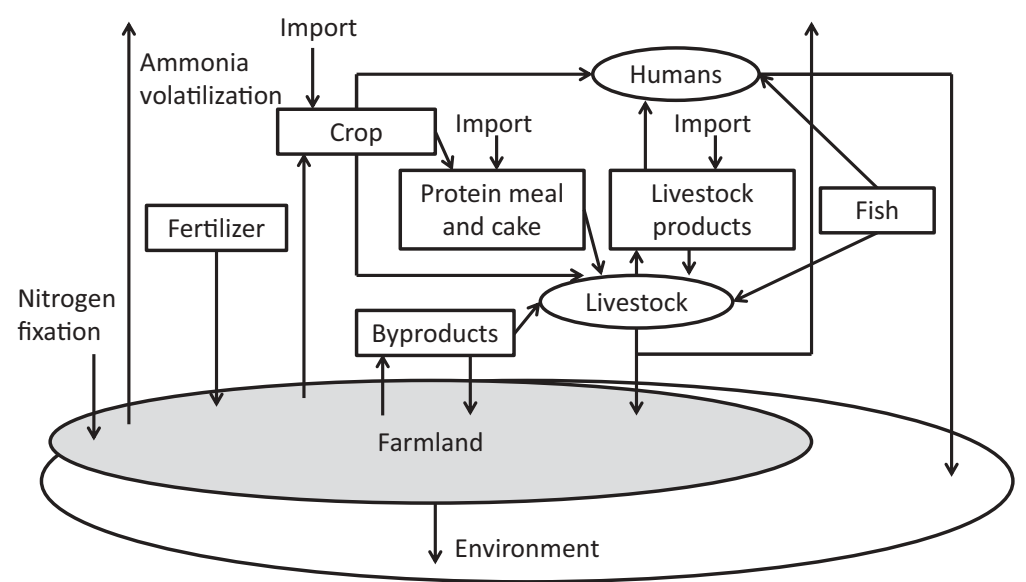

Figure 9.5 Nitrogen Flow Model 

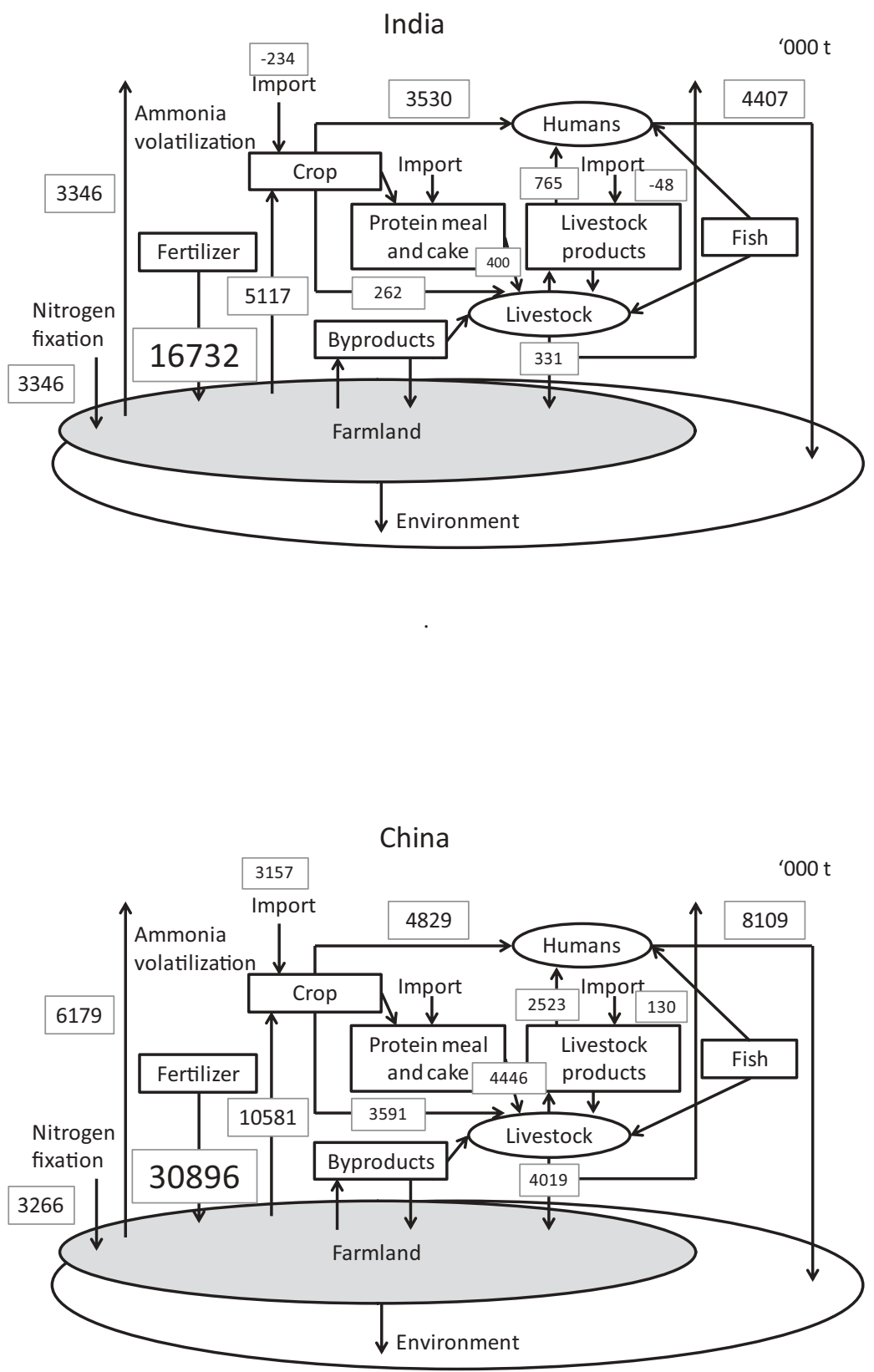

Figure 9.6 Nitrogen Cycles in India and China, 2013 
populations. Nitrogen fertilizers play a crucially important role in the nitrogen cycle both in India and China.

The most notable characteristic of the nitrogen cycle in India, especially compared with China, is that the flows related to livestock are small. One reason for this is that the demand for meat in India is extremely low compared to the demand in China. Although meat consumption in India has increased gradually in recent years, its per-capita consumption in 2013 remains much lower (3.7 kg/year) than the $59.7 \mathrm{~kg} / \mathrm{year}$ in China. Another factor is the low input of feed crops. There are more than one billion herds of livestock in India, but the cereal consumption for feed is extremely low. Regarding the macro nitrogen flow, nitrogen is not discharged to the environment merely by livestock animals eating grass in their surroundings (excluding ammonia volatilization). The quantity of nitrogen supplied to livestock through feed cereals and highprotein feed, such as soybean meal, is less than 10 percent of that in China.

China applies twice as much nitrogen fertilizer as India does. Its withdrawal from farmland through crops is also twice that of India because, in addition to producing a large quantity of crops for feed, about 27 percent of maize production is used in China for industrial purposes such as bioethanol production.

The scale of the nitrogen inflow to farmland by nitrogen fixation is similar in both countries. However, its contribution to the overall nitrogen cycle is higher in India because India produces large amounts of various pulses. The abundance of pulse production reflects the food culture in India. Pulses have played an important role by supplying protein in an alternative form to meat. They grow without application of nitrogen fertilizer. In terms of the nitrogen cycle, the adverse effect on the environment is less than that of the other crops. China consumes many soybeans for producing edible oils, but its production has decreased considerably. The supply of soybeans in China has come to be increasingly dependent on imports, especially from Brazil.

Because both countries have populations of more than a billion people, food self-sufficiency is a fundamentally important policy. Large amounts of inputs of nitrogen fertilizers must produce sufficient food domestically, which causes severe environmental problems. However, because of its unique food culture, India requires lower amounts of nitrogen fertilizers.

\subsection{Change in nitrogen flow in India}

To observe the temporal changes in nitrogen flow, data of the three years of 1961, 1981, and 2011 are used in the study, under the same method. Figure 9.7 clearly depicts the dynamic changes of the nitrogen cycle over the past 50 years. Nitrogen fixation played the most important role in India's nitrogen cycle in 1961. The amount of nitrogen fertilizer input in 1961 was only 1.3 percent of the amount in 2011. Most of the nitrogen flow into farmland was attributable to crops. As a result, there was little nitrogen to be discharged from the farmland to the environment. From the viewpoint of the nitrogen 
cycle, environmentally friendly food production was operated about 50 years ago. Thereafter, however, the nitrogen fertilizer input increased explosively. Nitrogen taken by the crops increased, but the growth rate was lower than that of the applied volume of nitrogen fertilizer. As a result, the gap separating the nitrogen fertilizer input and its withdrawal through crops widened. The amount of nitrogen discharged from farmland into the environment increased.
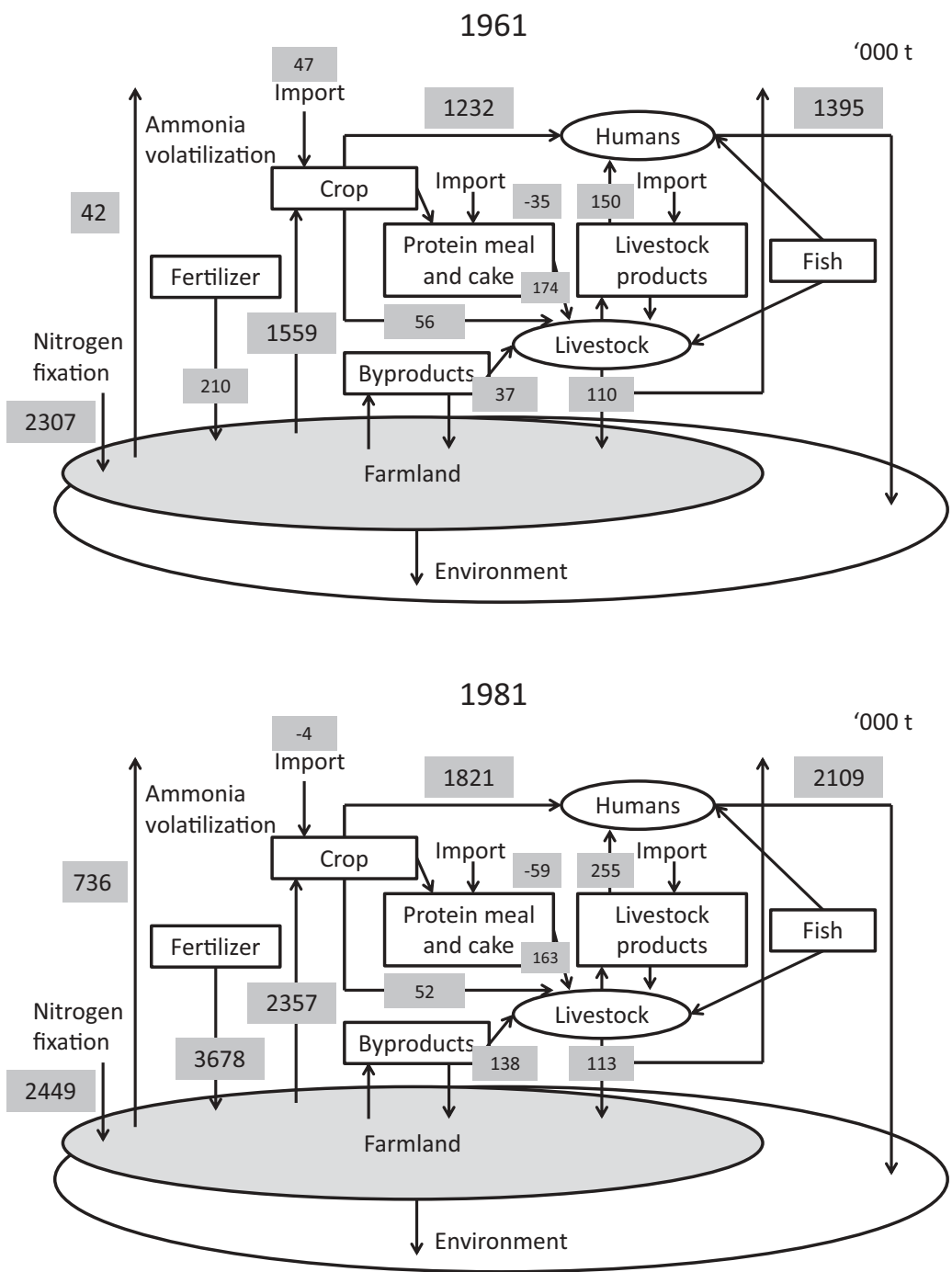

Figure 9.7 Changes in Nitrogen Flow in India: 1961, 1981, 2011 


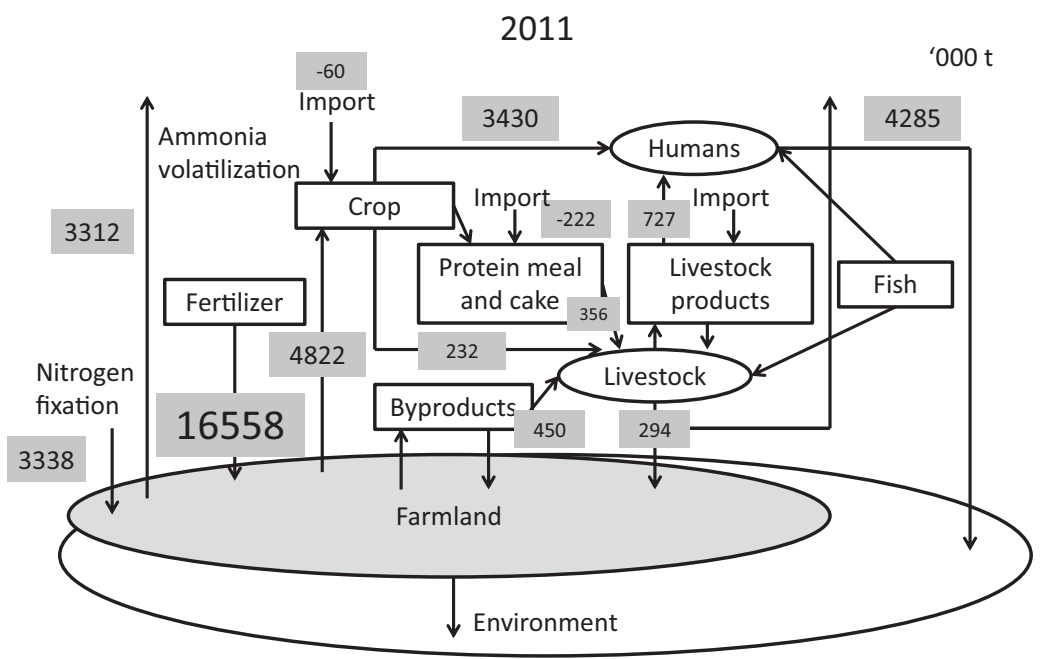

Figure 9.7 (Cont.)

The nitrogen flow of livestock also increased with the expanded consumption of feed crops. However, its effect on the overall nitrogen cycle was extremely small, even in 2011. The main factor underlying the increase in the demand for feed is usually the development of poultry farming. It is certain that the demand for chicken meat and eggs will continue to increase gradually. Therefore, intensive poultry farming, which uses large amounts of cereal feed, is expected to grow. Although the effects of livestock on the overall nitrogen cycle will continue to be insignificant, the local nitrogen load from intensive poultry farming can cause severe environmental pollution at a local level. Appropriate treatment of poultry excreta is necessary to prevent nitrogen emissions into the environment. For example, using poultry excreta as fertilizer for agriculture is effective to reduce both nitrogen emissions from poultry farms and nitrogen fertilizer inputs to farmland.

Nitrogen discharged through the excreta of humans into the environment has also increased. However, its growth rate has been almost equal to the population growth rate because per-capita protein consumption has not increased significantly. However, with increasing concentrations of population in urban areas, the nitrogen load from humans is causing severe environmental problems. This trend is expected to continue and measures such as constructing sewage treatment plants in the cities remain fundamentally important.

In terms of food trade, Figure 9.7 shows that India became a nitrogen exporter to a slight degree. In fact, India emerged as an important cereal (mainly rice) exporting country in the mid-1990s. The export of soybean 
meal is also significant. Soybean meal is a by-product of the soybean oil manufacturing industry. As the demand for edible oil increased, soybean meal production also increased. The meal that was not used for feed in India accordingly began being exported. However, the export of soybean meal has been decreasing since 2010 in response to a gradually growing demand for domestic feed in recent years. It is therefore questionable whether India will continue to be a nitrogen exporter.

As discussed earlier, the fertilizer subsidy system has contributed to three major changes in India: the achievement of food self-sufficiency through increased food production, severe fiscal deficits because of the increased fertilizer subsidies, and environmental pollution caused by nitrogen discharged from farmland. Summarizing the argument by integrating these three changes implies the following. The increase in nitrogen fertilizer input supported by the subsidy system has enabled India to increase cereal production. Consequently, India is now a cereal (rice) exporter. However, the nitrogen balance on farmland is deteriorating, which imposes a considerable overload on the Indian environment. Because the nitrogen discharged from farmland to the environment is spread across the entire country, it is difficult to remove it.

The only path to resolution of this difficulty without forfeiting self-sufficiency in food production in India is to increase nitrogen efficiency, that is, the ratio of nitrogen absorption in crops out of the nitrogen input. Improvement of nitrogen efficiency helps to minimize the amount of nitrogen input. Moreover, it helps to reduce the fertilizer subsidy. In Europe and in Japan, measures for improving nitrogen efficiency in agriculture have been implemented, but with decades of challenges and high costs. We examine this point next.

\section{Nutrient balance in soil and nitrogen efficiency}

One effective measure to enhance nitrogen efficiency is to improve the nutrient balance in soil. Fertilizing nutrients lacking in soil can increase the nitrogen absorption rate of crops against the nitrogen input. Gulati and Banerjee (2015) and Wani et al. (2016) pointed out that the imbalanced use of fertilizers has spread widely because of the irrational low price policy of urea. What type of fertilizer policy, then, is necessary to improve nitrogen efficiency by improving the nutritional balance in soil?

Table 9.1 shows widely various ratios of NPK fertilizer input in India by state. Gulati and Banerjee (2015) argued that the ideal ratio of NPK fertilizer input is 4:2:1. According to them, in some states such as Punjab, Haryana, and Rajasthan, the situation is truly alarming. They pointed out that the fertilizer policy did not give the right signals to the farmers to use fertilizers in a balanced manner. We investigated the relation between the NPK ratio of the whole of India and nitrogen efficiency to ascertain whether the ratio of $4: 2: 1$ is truly optimal, or not. 
Table 9.1 NPK Ratio by State

\begin{tabular}{lrrr}
\hline & $N$ & $P$ & $K$ \\
\hline A.P. & \multicolumn{1}{c}{$N$} & 2.0 & 1 \\
Karnataka & 3.0 & 1.5 & 1 \\
Kerala & 1.7 & 0.7 & 1 \\
Tamil Nadu & 3.2 & 1.2 & 1 \\
Gujarat & 10.6 & 3.1 & 1 \\
M.P. & 15.5 & 8.4 & 1 \\
Maharashtra & 3.0 & 1.5 & 1 \\
Rajasthan & 62.7 & 21.8 & 1 \\
Haryana & 28.0 & 7.0 & 1 \\
Punjab & 36.0 & 8.7 & 1 \\
U.P. & 16.9 & 4.9 & 1 \\
Bihar & 9.0 & 2.1 & 1 \\
Jharkhand & 28.3 & 6.0 & 1 \\
Odisha & 5.3 & 2.1 & 1 \\
W.B. & 2.4 & 1.2 & 1 \\
Assam & 1.9 & 0.6 & 1 \\
\hline
\end{tabular}

Source: Calculated from Agricultural Statistics at a Glance -2016 by the author.

Figure 9.8 presents estimation results for nitrogen efficiency obtained during 2000-2015. It appears that nitrogen efficiency improved slightly from 2010 in spite of the low consumption of $\mathrm{P} \& \mathrm{~K}$ fertilizers $(\mathrm{N}: \mathrm{P}: \mathrm{K}=9.9: 3.3: 1$ in 2012). We observed no relation between the NPK ratio and the nitrogen efficiency, perhaps because some factors other than fertilizer input have contributed to food production. However, it also indicates that the NPK ratio of 4:2:1 is not necessarily optimal overall. Moreover, as described in section 1, the decrease in $\mathrm{P} \& \mathrm{~K}$ fertilizer consumption did not strongly affect cereal production. The cereal production was stable even when the NPK ratio differed greatly from $4: 2: 1$. The ideal NPK ratio can vary greatly depending on crops, precipitation, temperature, soil quality, and other factors. For example, phosphate fertilizer is more likely to remain in the soil. If a large amount of phosphate fertilizer is applied in a certain year, then the amount of phosphate fertilizer required for the subsequent year decreases. Some discussion about the ideal NPK ratio for all of India or the entire state is not meaningful.

It is extremely important to ascertain the optimal NPK ratio for each crop on a smaller sub-district level. To discover the optimal nutritional balance, detailed soil testing is required. Wani et al. (2016) pointed out that soil health mapping and a taluk-level fertilizer recommendation are effective. In addition, education of farmers is important to help them implement an optimum fertilization plan based on recommendation. 


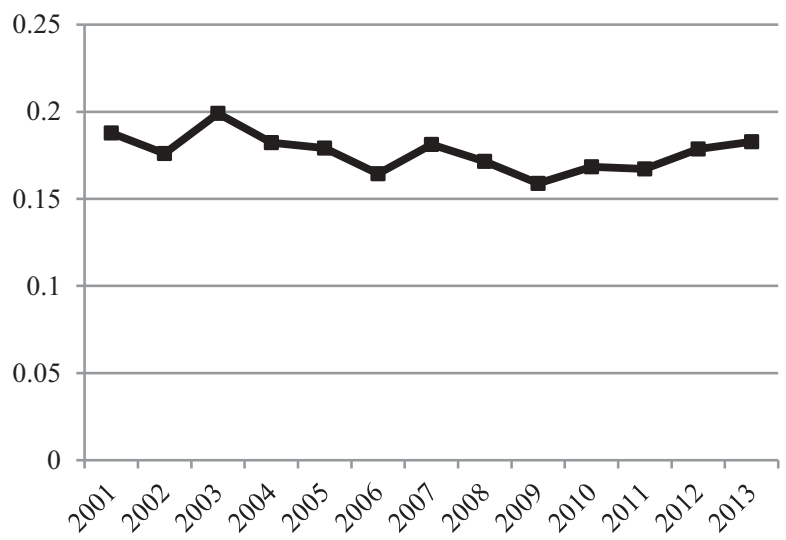

Figure 9.8 Nitrogen Efficiency, 2000-2013

How to change fertilizer prices to enhance nitrogen efficiency, and the extent to which they should be changed, is not readily known. Urea fertilizer is necessarily unreasonably cheaper than $\mathrm{P} \& \mathrm{~K}$ fertilizers. It is also true that overly large amounts of nitrogen fertilizer vis-à-vis $\mathrm{P} \&$ $\mathrm{K}$ fertilizers are used in many regions. Moreover, raising the retail price of urea fertilizer is effective for reducing fertilizer subsidies. However, as the case of $\mathrm{P} \& \mathrm{~K}$ fertilizers illustrates, policy changes to increase the price of urea fertilizer have a high risk of causing sharp decreases in its consumption. Furthermore, a sudden drop in nitrogen fertilizer consumption can threaten India's food security. Raising urea fertilizer prices should be done gradually and carefully and be accompanied by the monitoring of changes in nitrogen consumption and cereal production. If the consumption of nitrogen fertilizer can be reduced without reducing cereal production, then such a change might play an important role in alleviating both the environmental difficulties posed by nitrogen and the difficulties posed by decreased fertilizer subsidies.

Some measures other than improving the nutritional balance in soil can be used to increase nitrogen efficiency. For example, slow-release fertilizers, which are absorbed more easily, can increase nitrogen efficiency directly. Therefore, subsidies for slow-release fertilizers can become an effective policy to increase nitrogen efficiency. However, slow-release fertilizers present problems of high production costs. If production costs continue to be high, then the subsidy will be increased further. A further increase in production plant efficiency is fundamentally important.

After all, no silver bullet can solve all three problems, sustaining food production, reducing nitrogen pollution, and minimizing fertilizer subsidies. 


\section{Future demand for food and fertilizers}

How, then, will the future demand for food affect the fertilizer subsidy system? As described in section 1, the most fundamental objective of the fertilizer subsidy system is to produce more food. Although self-sufficiency of cereals is achieved, food production is still important to satisfy the growing population of India. To estimate the future demand for food, it is necessary to analyze the trends in population size and per-capita food demand.

The World Population Prospect (WPP) 2017 revision (United Nations Department of Economic and Social Affairs Population Division, 2017), the most widely used population estimate, revised their projection concerning India's future population downward. In the WPP 2015 revision (United Nations Department of Economic and Social Affairs Population Division, 2017) the total population in 2050 was estimated as 1.705 billion in a medium variant. The WPP 2017 revision placed it at 1.659 billion. This difference cannot be overlooked in these population projections, which are fundamentally more accurate than those in other fields. The main factor behind this modification is the decline in the assumed total fertility rate (TFR).

The pace of decline in TFR for all of India was extremely slow until the early 1980s (Figure 9.9). It accelerated slightly and maintained a constant pace after the late 1980s. The TFR differs substantially by state: it is higher in the north and lower in the south. In Tamil Nadu and Kerala, the TFR

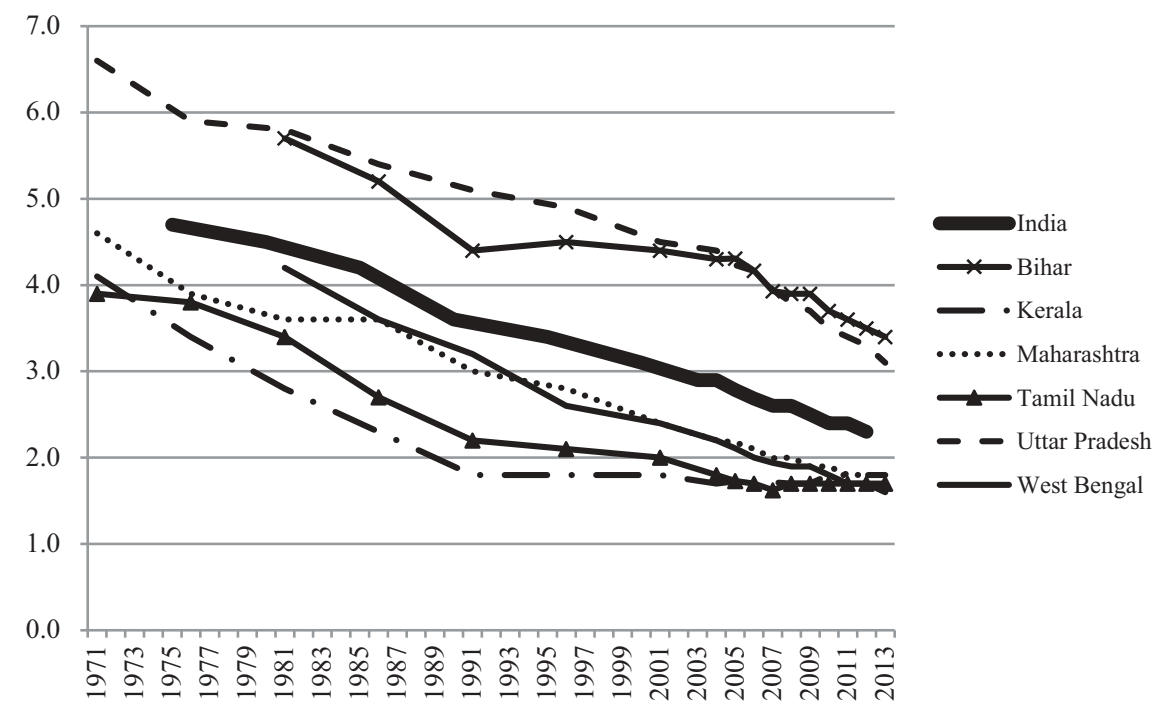

Figure 9.9 Total Fertility Rates in Major States of India

Source: SRS Statistical Report 2015. 
had declined below 2.30 by 1990 . However, the TFR in less economically developed states such as Bihar and Uttar Pradesh respectively remained above 4.00 until 2006 and 2008. The slow pace of decline in the TFR in these two states had a dampening effect on the decline in TFR for India as a whole. It is noteworthy that the TFR in Uttar Pradesh and Bihar was almost unchanged between the 1990s and the early 2000s, when TFR in most states decreased steadily. However, after 2005, the drop in TFR finally started to accelerate in these two states. It is reasonable to assume that the TFR will continue falling in Uttar Pradesh and Bihar. No other state experienced any halt in the decline before it fell below 2.00. The drop in TFR in the most-populated states is a favorable factor for controlling population growth in India.

The medium variant of the WPP 2017 revision estimated India's future TFR to be less than 2.0 during 2035-2040. Assuming that this pace of decline in TFR will continue in the future, it will become less than 2.0 by 2025, at the latest. The projection of the WPP 2017 revision appears to be something of an overestimation. The WPP 2017 revision estimated that the absolute population in India will begin to decline from 2061. However, it is possible that India's population will peak by 2050 .

According to FAOSTAT, the per-capita annual consumption figures for rice and wheat in India in 2013 were, respectively, $69.5 \mathrm{~kg}$ and $60.6 \mathrm{~kg}$. The per-capita annual consumption of rice peaked at $79.1 \mathrm{~kg}$ in 1989 . It decreased gradually thereafter. The per-capita annual consumption of wheat exceeded $60 \mathrm{~kg}$ for the first time in 1991, and thereafter remained almost unchanged. The per-capita consumption figures for rice and wheat are not expected to increase in the future. In many economically developing countries, the demand for cereals for use as feed has risen because of increased meat consumption. However, demand for feed cereals has remained low in India because of its food culture, as described above.

Even if the population grows as projected by WPP 2017, the population of India in 2030 will be only 14.7 percent larger than the population in 2015 . To estimate the cereal demand in 2030, we assume that per-capita consumption of rice and wheat shall remain at current levels and that maize for feed shall increase 2.5 times (about 6 percent annual growth). As a result, the total demand for the three cereals in 2030 will be only 22.3 percent larger than in 2015 . This growth is not rapid compared to that of India's cereal production in the past.

The limited growth of cereal demand is a favorable factor for resolving fertilizer subsidy difficulties. Because the growth in nitrogen fertilizer demand will not be so great in the future, the environmental problems and the financial deficit are not expected to deteriorate substantially. However, stagnated demand for cereals is not desirable for farmers. Stagnation of demand will engender price rigidity. Moreover, the growth gap separating agriculture and non-agriculture will be expanded. It will be necessary to change subsidy policy to a policy that compensates farmers' income directly. Future subsidies will not be allocated to fertilizer manufacturing. A 'production neutral' policy, such as one providing incentives for environmentally friendly 
agriculture, will be planned. The Direct Benefit Transfer (DBT), which is being discussed actively at the moment, is a suitable scheme to implement a production-neutral policy. The latter is important not only in the context of the current fertilizer subsidy system but also for future systems.

\section{Note}

1 On the agricultural subsidy issues, see for example, Gulati and Narayanan (2003).

\section{References}

Department of Agriculture, Cooperation and Farmers Welfare, Ministry of Agriculture and Farmers Welfare, Government of India (2016). Agricultural Statistics at a Glance 2016, http://apy.dacnet.nic.in/cps.aspx/ Accessed in June 2017.

Department of Fertilizers, Ministry of Chemicals \& Fertilizers, Government of India. "Fertilizer Policy," http://fert.nic.in/page/fertilizer-policy Accessed in June 2017.

FAO, FAOSTAT. http://faostat.fao.org/. Accessed in January 2013.

Gulati, A. and P. Banerjee (2015). "Rationalising Fertiliser Subsidy in India: Key Issus and Policy Options," ICRIER Working Paper 307, Indian Council for Research on International Economic Relations.

Gulati, A. and S. Narayanan (2003). The Subsidy Syndrome in Indian Agriculture, New Delhi: Oxford University Press.

National Sample Survey Organization, Ministry of Statistics \& Programme Implementation, Government of India (2012). Nutritional Intake in India 2009-2010, New Delhi: National Sample Survey Organization.

Office of the Registrar General \& Census Commissioner, India, Ministry of Home Affairs, Government of India (2014). SRS Statistical Report 2013, New Delhi, Office of the Registarar General \& Cencus Commissioner, India, Ministry of Home Affairs, Government of India.

Office of the Registrar General \& Census Commissioner, India, Ministry of Home Affairs, Government of India (2016). SRS Statistical Report 2015, New Delhi, www. censusindia.gov.in/vital_statistics/SRS_Statistical_Report.html Accessed in June 2017.

Shindo, J. (2012). "Changes in the Nitrogen Balance in Agricultural Land in Japan and 12 Other Asian Countries Based on a Nitrogen-flow Model," Nutrient Cycling in Agroecosystems, vol. 94, pp. 47-61.

The Fertilizer Association of India (2009). Fertilizer and Agriculture Statistics 2008-2009, New Delhi, Fertilizer Association of India.

The Fertilizer Association of India (2011). Fertilizer Statistics 2010-2011, New Delhi.

United Nations Department of Economic and Social Affairs Population Division (2015). World Population Prospects: The 2015 Revision, http://esa.un.org. Accessed in December 2015.

United Nations Department of Economic and Social Affairs Population Division (2017). World Population Prospects: The 2017 Revision, http://esa.un.org Accessed in June 2017.

USDA, PSD Online. https://apps.fas.usda.gov/psdonline/ Accessed in June 2017.

Wani, S. P. et al. (2016). "Soil Health Mapping and Direct Befit Transfer of Fertilizer Subsidy,” ICRISAT Research Report IDC-6, ICRISAT Development Center. 


\title{
10 Sustainability of groundwater-irrigated agriculture in India
}

\author{
Case studies of Punjab and Tamil \\ Nadu
}

\author{
Takahiro Sato
}

HIROSAKI UNIVERSITY

\section{Introduction}

India is the most drought prone country in the world. More than 75 percent of its cultivated areas are in semi-arid tropics (CED, 2010). Moreover, the area under semi-arid climate has increased because of climate change (Rao et al., 2013). In such areas, the strongest constraint on agricultural production is water. Traditional cultivation methods and irrigation facilities were maintained historically by local societies to maximize or stabilize agricultural production under water-scarce conditions (Palanisami, 2000; Mosse, 2003). Since Independence, the extension of irrigation facilities has persisted as a central feature of India's agricultural development strategy, although most investment efforts have emphasized major and medium surface irrigation projects. Groundwater development was encouraged by providing institutional finance, investment in rural electrification, and subsidized provision of credit and energy (Vaidyanathan, 2006). As a result, a groundwater revolution began throughout India during the mid-1970s: numbers of irrigation wells equipped with diesel or electric pumps increased from around 150,000 in 1960 to nearly 20 million by 2000 (Shah, 2008c). Such dramatic expansion of groundwater irrigation contributed to increased rice and wheat yields per unit of land (Sivasubramaniyan, 2006; Esho, 2008).

Annual groundwater withdrawals in the Indian Sub-Continent currently exceed $340 \mathrm{bcm}$, representing the most voluminous use of groundwater in the world (Mukherjee et al., 2015). However, a steady decline of the groundwater level because of overexploitation became apparent especially in northwestern and southern India (Suhag, 2006). Recently, profiling food, water, and energy as a nexus has been promoted strongly as a global research agenda and an emerging development paradigm (Leck et al., 2015; Smajgl et al., 2015). This analytical framework is also applicable in India, where the sustainability of crop production for meeting demand from increasing population depends on the means of securing groundwater irrigation, but subsidies for agricultural electricity to pump up groundwater have burdened the financial status of the 
state electricity board, as described in Chapter 7 of this book volume by Fujita and Fukumi. Shah (2008a) demonstrated that the nexus between electricity supply and irrigation has emerged as the pivot of vote-bank politics in the region and that it has triggered a battle of wits between pump irrigators on the one hand and politicians, technocrats, and international agencies on the other.

The hydrogeological settings of groundwater in India can be categorized by two main features: alluvial aquifers of the Indo-Gangetic plains and hard-rock aquifers of peninsular India (Suhag, 2006). Alluvial aquifers are regarded as among the most productive aquifers in the world, but hard-rock aquifers, supplying two-thirds of the country, have limited groundwater potential within the weathered zones and underlying fractured aquifers (Mukherjee et al., 2015). Although the benefits of technological development related to groundwater irrigation can cover all of India, sustainability of groundwater-irrigated agriculture will be affected strongly by its hydrogeological characteristics.

This chapter presents specific examination of the sustainability of groundwater-irrigated agriculture from a technological perspective rather than a socioeconomic one, based on statistical information and fieldwork conducted in selected villages in Punjab and Tamil Nadu. Two states were selected because of their different hydrogeological characteristics: alluvial aquifers in Punjab and hard rock aquifers in Tamil Nadu. For both states, agricultural changes corresponding to the expansion of well irrigation are presented initially. Then, the environmental and economic sustainability of paddy rice production in the selected village, which consumes much water, will be presented. In discussion, the possible government intervention for sustaining groundwater-irrigated agriculture in both states will be proposed, considering current circumstances. Finally, a summary and conclusion follow.

\section{Groundwater-irrigated agriculture in Punjab}

\subsection{Agricultural intensification caused by a well irrigation boom}

The biome of Punjab province is categorized as "Deserts and Xeric Shrub lands," especially because of low rainfall (Olson et al., 2001). However, a high potential of groundwater irrigation exists in this province: alluvial soils that had been carried by Himalayan snowmelt widely cover this area. Fairly thick and confined and unconfined aquifers extend up to $300 \mathrm{~m}$ (Bobba et al., 1997). Two-thirds of groundwater recharge derives from seeped-in canal waters (Dhawan, 1993) connected to the rivers of the Indus water systems, such as the Ravi, Beas and Satraj rivers (Map 10.1).

Originally, Punjab had two agricultural zones: The central zone in which wheat was cultivated as a principal crop, and the other arid or semi-arid zone where livestock farming was dominant (Sugimoto and Usami, 2014). With the benefit of large-scale canal development such as the Triple Canal project (Singh, 2005), irrigated areas in Punjab province increased 1.78 times during 1901-1944. These canal projects mainly provided irrigation 


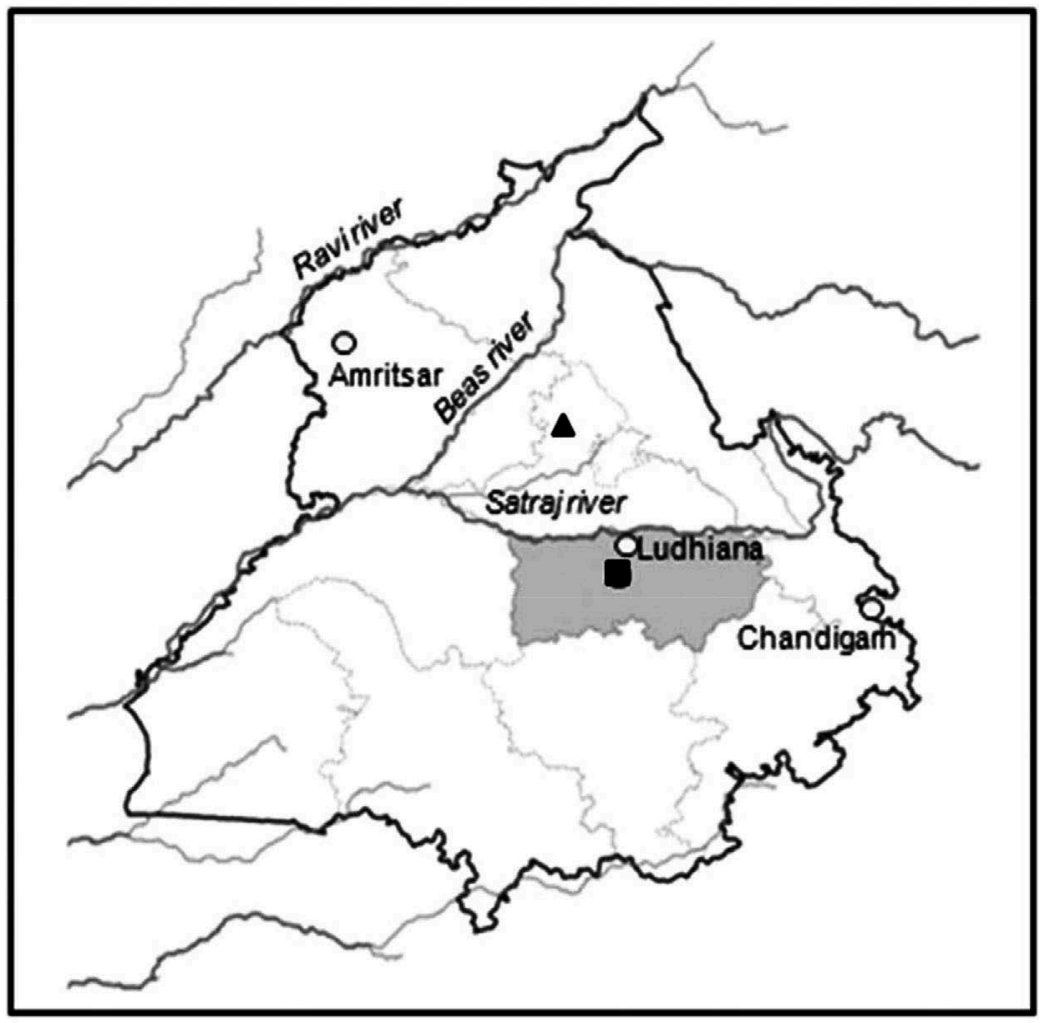

- Sample village for water balance calculation

- Sample village for production cost survey

Map 10.1 Location of Study Area in Punjab

Note: Gray lines indicate administrative boundary in 1966.

water access to the rainfed zone. Therefore, expansion of water-intensive agriculture was not expected. Such canal development continued after Independence, but some farmers also began to install tube wells (Sugimoto and Usami, 2014).

Figure 10.1 presents the normal monthly rainfall and potential evapotranspiration (PET) in Ludhiana, Punjab. The annual rainfall amount is $706 \mathrm{~mm}$. More than 75 percent of that is concentrated in the southwest monsoon season (kharif). Paddy production is currently dominant in kharif, followed by wheat cultivation starting from November. Figure 10.2 presents changes of farmers' crop choices in Ludhiana district. In the mid-1960s, wheat accounted for 43.9 percent of the total cultivated 


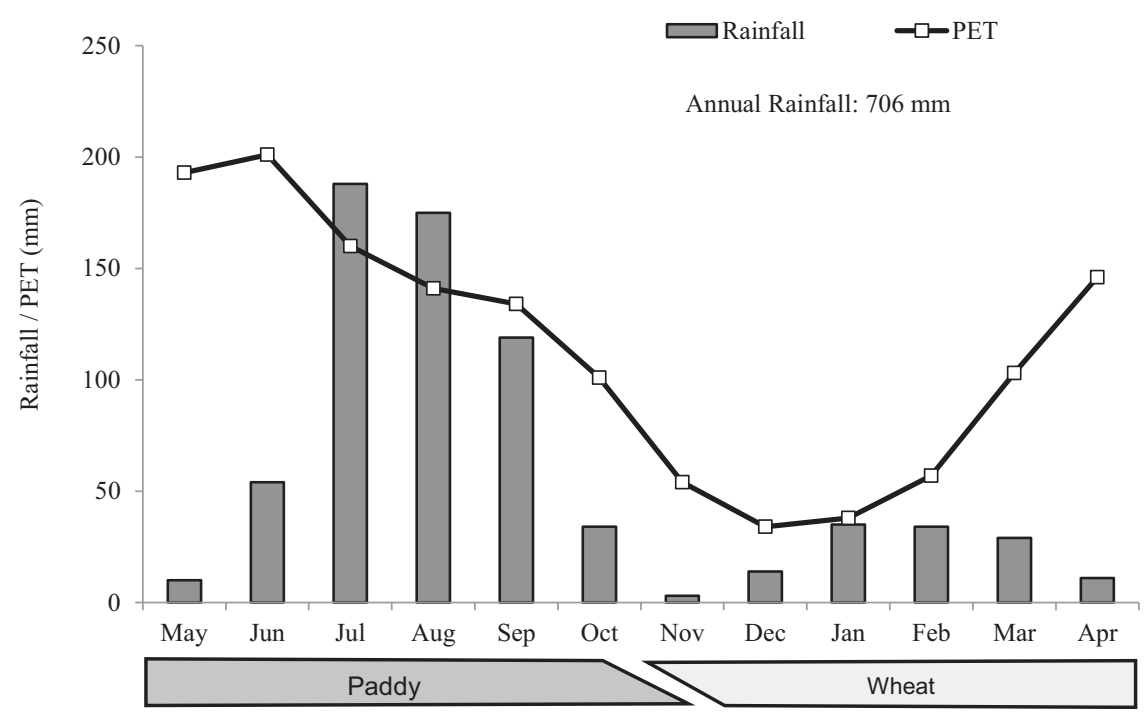

Figure 10.1 Monthly Rainfall and Potential Evapotranspiration (PET) in Ludhiana, Punjab

Source: Prepared by data from ICRISAT (2015) and author's field survey.

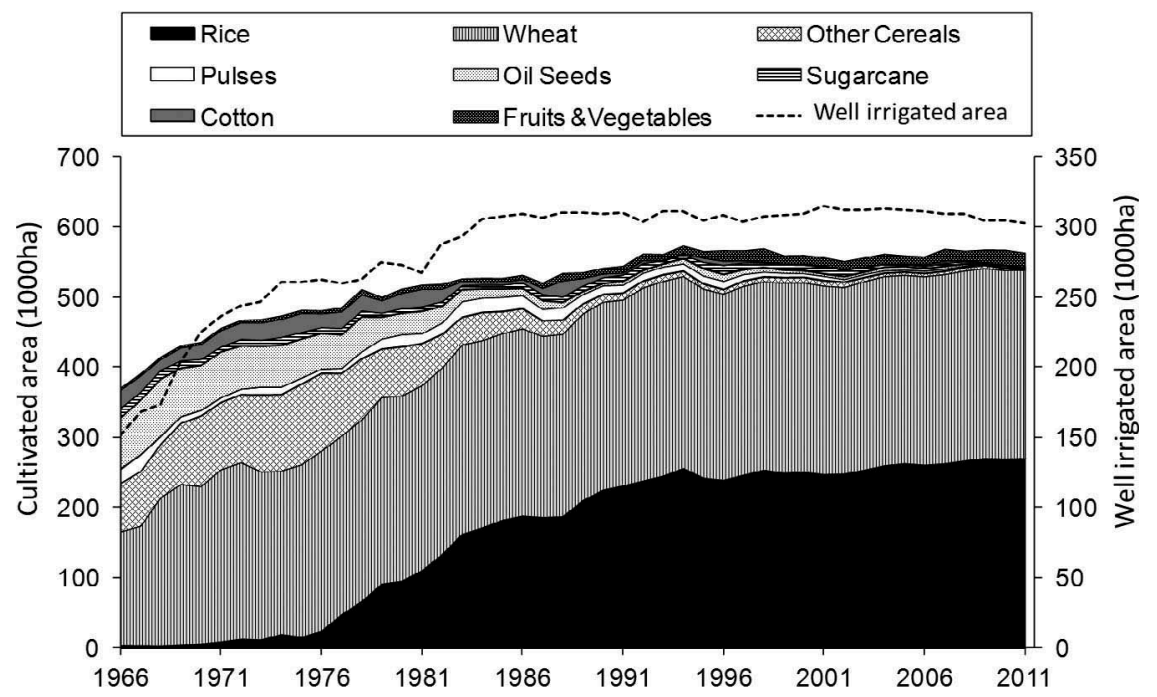

Figure 10.2 Inter-temporal Changes in Crop Choice in Ludhiana, Punjab

Source: Prepared by author based on data from ICRISAT (2015). Note: Administrative boundary in 1966 was used to illustrate this figure. 
area, but other cereals or oilseeds such as maize or ground nut were also cultivated. Rice cultivation was negligible at this time. However, crops other than wheat were converted to paddy rice from the mid-1970s, corresponding to the expansion of well irrigated area. The sum of the rice and wheat cultivation accounted for 96 percent of the total cropped area in 2011. The combination of these two crops is commonly observed at the state level (Sarkar and Das, 2014; Vatta, 2015).

Introduction of tube wells was supported by government intervention of three kinds: rural electrification, finance for farm equipment (Dhawan, 1975), and subsidies for agricultural electricity use. The last one started from 1984 in Punjab. It was then followed by free electricity provision from 1997 (Sarkar and Das, 2014). Introduction of high yielding varieties, widely known as the "Green Revolution," was also supported by government subsidies for the other agricultural inputs (seed, fertilizer, and pesticide) and procurement policy. Dramatic yield increases were achieved both for rice (from 0.91 to $4.26 \mathrm{t} / \mathrm{ha}$ ) and wheat (from 2.47 to $5.37 \mathrm{t} / \mathrm{ha}$ ) between 1966 and 2011 (ICRISAT, 2015). Expansion of tube well irrigation was an extremely important factor for the establishment of current rice-wheat monoculture in Punjab.

\subsection{Case of farm villages in Ludhiana District ${ }^{1}$}

To investigate the sustainability of groundwater-irrigated agriculture in Central Punjab, field surveys were conducted in two villages close to Ludhiana city (Map 10.1). Table 10.1 presents basic characteristics of a sample village with 301 households. Average operational holdings were more than twice their land holdings. Many landholders migrated to the UK, Australia, Canada, and to other economically developed countries. Subsequently, they leased-out their land to village residents. Rice-wheat cultivation occupied 80 percent of the total agricultural area, although maize or fodder cultivation was also observed.

According to the electrical substation covering this village, the total number of groundwater pump-sets was 75 in 2014. The number of pumpsets was the same in 2015, but some of the pump-sets $(7.5 \mathrm{HP} \times 1,10 \mathrm{HP}$ $\times 2$ ) were replaced by those with higher capacity $(15 \mathrm{HP})$. The average capacity of these pump-sets was 10.7 HP in 2015. Pump-sets with capacity of 12.5 HP or $15 \mathrm{HP}$ are currently hot sellers in pump-set shops in Ludhiana. Such an upgrading of pump-sets resulted from the continuing decline of the groundwater table. Conversion from centrifugal pumps to submersible pumps in this village started from 2002 and ended in 2010. According to interviews with farmers, the groundwater level dropped from $17.5 \mathrm{~m}$ in 2005 to $26 \mathrm{~m}$ in 2015. Total costs ${ }^{2}$ of tube well installation were around Rs.114,000. Landowners are responsible for their maintenance.

Geological strata ${ }^{3}$ and the water balance of rice production in a sample village are presented in Figure 10.3. Sandy and clayey soil layers are 
Table 10.1 Characteristics of NK village, Ludhiana, Punjab

\begin{tabular}{llcl}
\hline Items & & Number & \\
\hline Total Number of Household $^{1}$ & & 301 & $(\mathrm{HH})$ \\
Total Population $^{1}$ & & 1,443 & $\begin{array}{l}\text { (people) } \\
\text { Total Agricultural Area }^{2}\end{array}$ \\
Average Land Holdings $^{2}$ & & 181.8 & $(\mathrm{ha})$ \\
Average Operational Holdings $^{2}$ & & 1.46 & $(\mathrm{ha} / \mathrm{HH})$ \\
Cropping Pattern $^{2}$ & & 3.34 & $(\mathrm{ha} / \mathrm{HH})$ \\
& Rice-Wheat & 80.2 & $(\%)$ \\
& Rice-Maize & 10.9 & $(\%)$ \\
& Fodder Crops & 7.9 & $(\%)$ \\
Characteristics of tube well $^{2}$ & Others & 1 & $(\%)$ \\
& Depth of Bore & 95 & $(\mathrm{~m})$ \\
& Depth of Delivery Pipe & 35 & $(\mathrm{~m})$ \\
& Groundwater Level & 26 & $(\mathrm{~m})$ \\
\hline
\end{tabular}

Data source:

${ }^{1}$ GOI (2013b).

${ }^{2}$ Author's field survey in 2016.

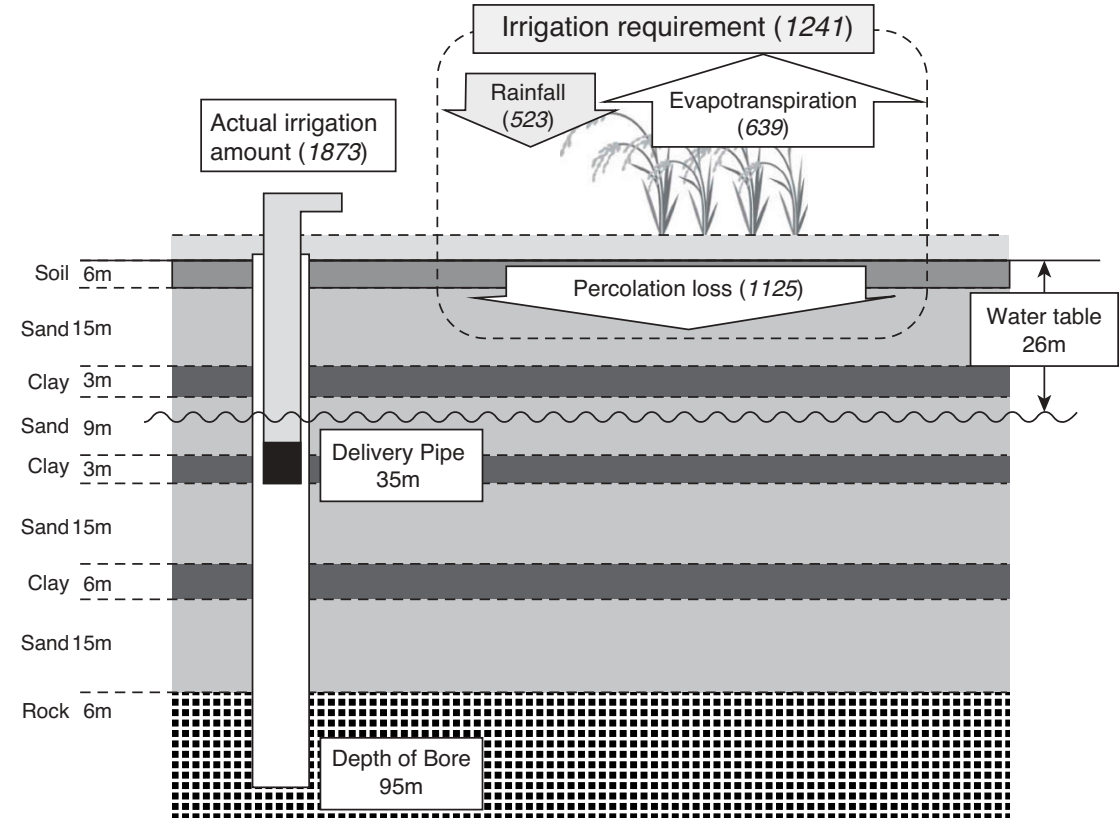

Figure 10.3 Geological Stratum and Water Balance in Rice Production in Punjab Note: Numbers in brackets indicate water amount $(\mathrm{mm})$. 
stratified up to $72 \mathrm{~m}$ below ground, which allows water to infiltrate deeper into the soil layer. Farmers sow their seeds in nurseries around May 20, transplant seedlings on June 15 (as regulated by the government) and harvest at the end of October. Evapotranspiration ${ }^{4}$ and percolation losses 5 during rice cropping season were estimated respectively as $639 \mathrm{~mm}$ and $1,125 \mathrm{~mm}$. The sum of these values $(1,764 \mathrm{~mm})$ shows the standard water requirement of paddy production in this area. Normal rainfall during this period was estimated as $523 \mathrm{~mm} .{ }^{6}$ Therefore, it is necessary to irrigate $1,241 \mathrm{~mm}$ of water to ensure proper growth. However, the actual irrigation amount was estimated as $1,873 \mathrm{~mm},{ }^{7}$ which is 50.8 percent higher than the irrigation water requirement.

Various limitations engender instability and necessitate the rotation of the agricultural electricity supply. The daily electricity supply is limited to 8 hours during kharif season (June 15 - October 31), but farmers also experience frequent power outages during these 8 hours. Moreover, the supply time rotates every 4 days on a 24 hour basis. Responding to such electricity supply, most farmers installed automatic switches that turn on the pump-set whenever electricity is available. Farmers are often observed draining excess water from their paddy fields.

Production and costs of rice production in Punjab are presented in Table 10.2. Because of higher yield and minimum support prices provided by the government, gross income was higher than Rs.100,000/ha in this case. Production costs and land rent accounted respectively for 30.6 percent and 30.7 percent of gross income. As described previously, land rent includes maintenance and depreciation costs of the tube well. Results show that net income became around Rs.39,000/ha. The share of profit in rice production was 38.7 percent. However, that table does not include electricity costs for pumping groundwater because of the free electricity supply. The amount of electricity used for pumping up $1,873 \mathrm{~mm}$ of groundwater can be estimated as $3,016 \mathrm{kWh} / \mathrm{ha}$ for the $12.5 \mathrm{HP}$ pump-set. Shah (2008a) demonstrated that pump irrigation became uneconomic for most farmers in several regions in India when charged at a rate of Rs. $2 / \mathrm{kWh}$. Corresponding costs for irrigating paddy fields became Rs.6,032/ha, accounting for only 6 percent of gross income. However, industrial electricity use in Punjab is currently charged at the rate of Rs. $8-9 / \mathrm{kWh}$ : electricity costs are expected to be 25 percent of gross income if agricultural electricity charges are the same as those for industrial use.

\section{Groundwater-irrigated agriculture in Tamil Nadu}

\subsection{Spatiotemporal changes of farmers' crop choice}

Tamil Nadu state, located at the southeastern tip of the Indian subcontinent (Map 10.2), is recognized as a monsoon shadow area because the humid southwest monsoon is blocked by the Western Ghats Mountains, located at 
Table 10.2 Production and Cost of Rice Production in Ludhiana, Punjab

\begin{tabular}{llrl}
\hline Production & Yield (kg/ha) & 6,683 & \\
& Farm Gate Price (Rs./kg) & 15.1 & \\
& Gross Income (Rs./ha) & 100,913 & $(100 \%)$ \\
Input and Labor Cost & Land Preparation(Rs./ha) & 4,950 & \\
& Seed (Rs./ha) & 594 & \\
& Transplanting/Sowing (Rs./ha) & 6,931 & \\
& Fertilizer \& Pesticide (Rs./ha) & 11,038 & \\
& Harvesting (Rs./ha) & 7,391 & \\
& Sub Total (Rs./ha) & 30,904 & $(30.6 \%)$ \\
Net Income (Rs./ha) & Land Rent (Rs./ha/season) & 30,941 & $(30.7 \%)$ \\
& & 39,069 & $(38.7 \%)$ \\
Irrigation & & & \\
& Groundwater Amount (mm) & 1,872 & \\
& Electricity Use (kWh/ha) & 3,016 & \\
& Electricity Cost (Rs./ha) & 0 & \\
& (with unit charge of 2 Rs./kWh) & 6,032 & $(6.0 \%)$ \\
& (with unit charge of 8.5Rs./kWh) & 25,636 & $(25.4 \%)$ \\
\hline
\end{tabular}

Source: Author's field survey in 2016.

Note: Half of the annual land rent is presented in this table considering wheat cultivation after rice.

the western border of the state. Under such climatic conditions, a tank irrigation system has been developed and maintained by local societies over many centuries. More than 39,000 tanks of varying size and type exist in Tamil Nadu (Palanisami, 2000). Madurai district, examined in the present study, is known as a center for tank-irrigated agriculture (Amarnath and Raja, 2006). Normal monthly rainfall and PET in the Madurai district is shown in Figure 10.4. The annual rainfall amount is $905 \mathrm{~mm}, 42$ percent of which is concentrated during the northeast monsoon season. Agricultural land in tank irrigation systems is divided into two categories: The tank command area (nanjai in Tamil), and dryland (punjai) which usually functions as a catchment area for downstream tank water storage. The punjai area is normally 5-15 times larger than the nanjai area. In a traditional cropping pattern, paddy rice is cultivated in nanjai during the northeast monsoon season, followed by millet and other crops. The cropping sequence of millet-fallow was traditionally dominant in punjai. In the case of Madurai district, three irrigation sources (tank, canal and well) held equal importance until the mid-1960s (Sato, 2016) for two reasons. A major irrigation scheme, "The Periyar Project," started from 1887 to increase the canalirrigated area by 2.4 times during 1896-1905 (Francis, 1906). In the drier area located in the northwestern part of the district, well irrigation was 


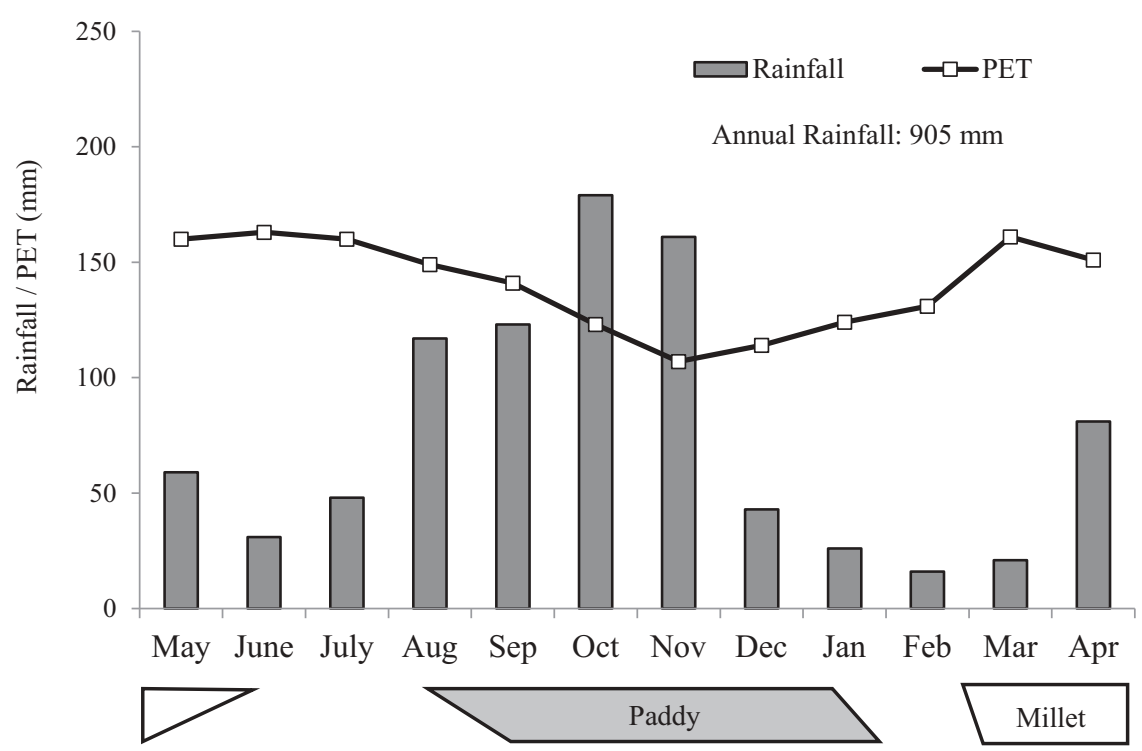

Figure 10.4 Monthly Rainfall and Potential Evapotranspiration (PET) in Madurai, Tamil Nadu

Source: Prepared by author based on data from ICRISAT (2015).

traditionally used to cultivate millet, horse grains, and cash crops such as tobacco (Francis, 1906).

Promotion of new well installation in Tamil Nadu started during World War II, but it accelerated when government shifted its focus from a major/ medium irrigation scheme to the exploitation of groundwater potential from 1969. Figure 10.5 depicts inter-temporal changes in crop choices and wellirrigated areas. Well-irrigated areas started to increase from the 1970s, eventually accounting for 72 percent of the total irrigated area in 2011. This increase reflects the results of state government promotion of new well installation, deepening of existing wells, and pump-set energization (GOTN, 1970). Moreover, subsidized agricultural electricity supply also started from the mid-1980s: A flat rate system was introduced in 1984, but electricity for agricultural purpose later became free (Palanisami et al., 2008). The cost of well installation also decreased in the 1990s, mainly because of the decline of pump-set prices and drilling costs (Kajisa et al., 2007). Well irrigation expanded during this period. However, agriculture in Madurai had not intensified as that of Punjab: The cropping area decreased 47 percent during 1966-2011. Promotion of well-irrigated agriculture seemed to enhance only crop conversion from millet, with less irrigation requirement, to fruits and vegetables requiring timely irrigation. 


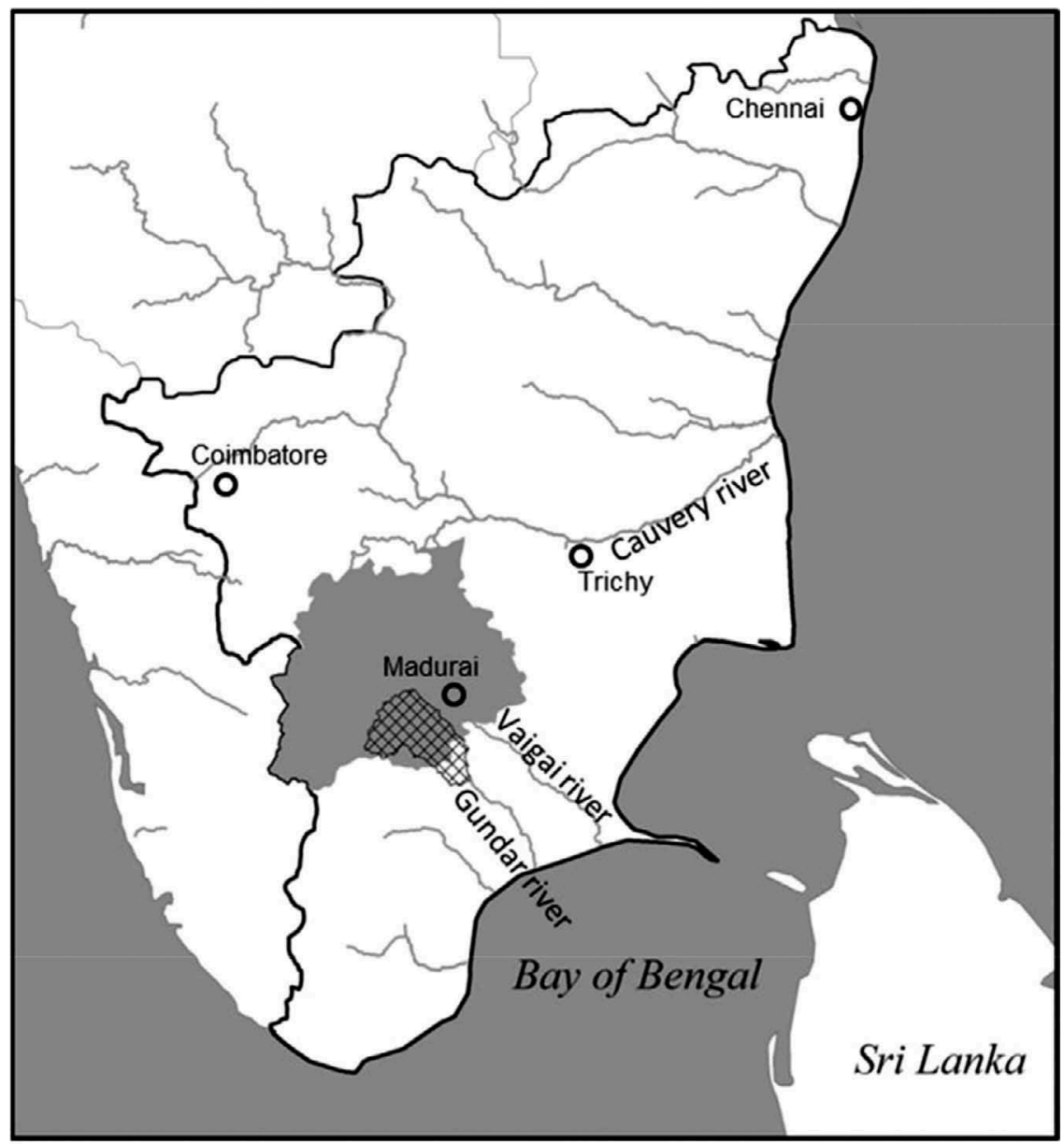

\section{Upper Gundar River Basin}

Map 10.2 Location of Study Area in Tamil Nadu

Note: Administrative boundary in 1966 was used to illustrate this figure.

Map 10.3 presents the topography and well density in the upper part of Gundar River Basin. This seasonal river starts to Western Ghats Mountains and flows southeast toward the Bay of Bengal. The 384 tanks within this river basin feed water to the area of 13,549 ha (Government of Tamil $\mathrm{Nadu}, 2009$ ). Many are connected to the river to store river water in 

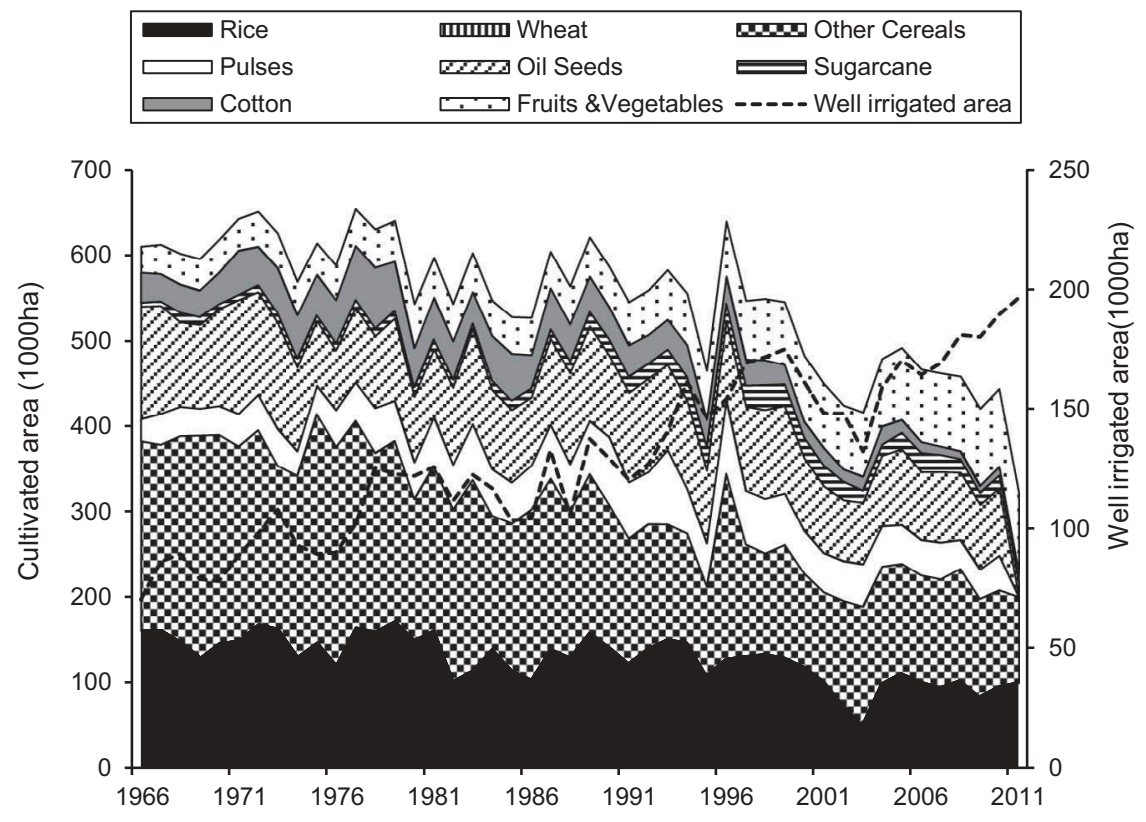

Figure 10.5 Inter-temporal Changes in Crop Choice in Madurai, Tamil Nadu

Source: Prepared by author based on data from ICRISAT (2015).

Note: Administrative boundary in 1966 was used to illustrate this figure.

a tank. The spatial distribution of the density of dug well (Map 10.3b) apparently indicates the well concentration in the upper basin. Farmers' crop choices are affected strongly by such a spatial distribution. Changes in the crop composition of three villages located at upper, middle, and lower basin (Map 10.3a) are presented in Figures 10.6 and 10.7. First, we examine cropping changes in nanjai. The cropping intensity in the upper basin increased slightly during both rainy and dry seasons during 1998-2008. Shares of fruits and vegetables, and millet during the dry season also increased during this period. In the middle basin village, the share of sugarcane cultivation increased, but no clear difference existed in cropping intensity between 1998 and 2008. For villages of the lower basin, cropping intensity of 2008 in both rainy and dry seasons decreased to the half of that in 1998. Regarding crop cultivation in punjai, similar tendencies were observed during the rainy season. Dry season cropping in punjai remained at a low level for villages of the middle and lower basin, but that in the upper basin also increased during this period. Such spatiotemporal differences of farmers' crop choices were the result of unequal well distribution indicated in Map 10.3b (Sato and Periyar, 2011). 


\section{(a) Topography}

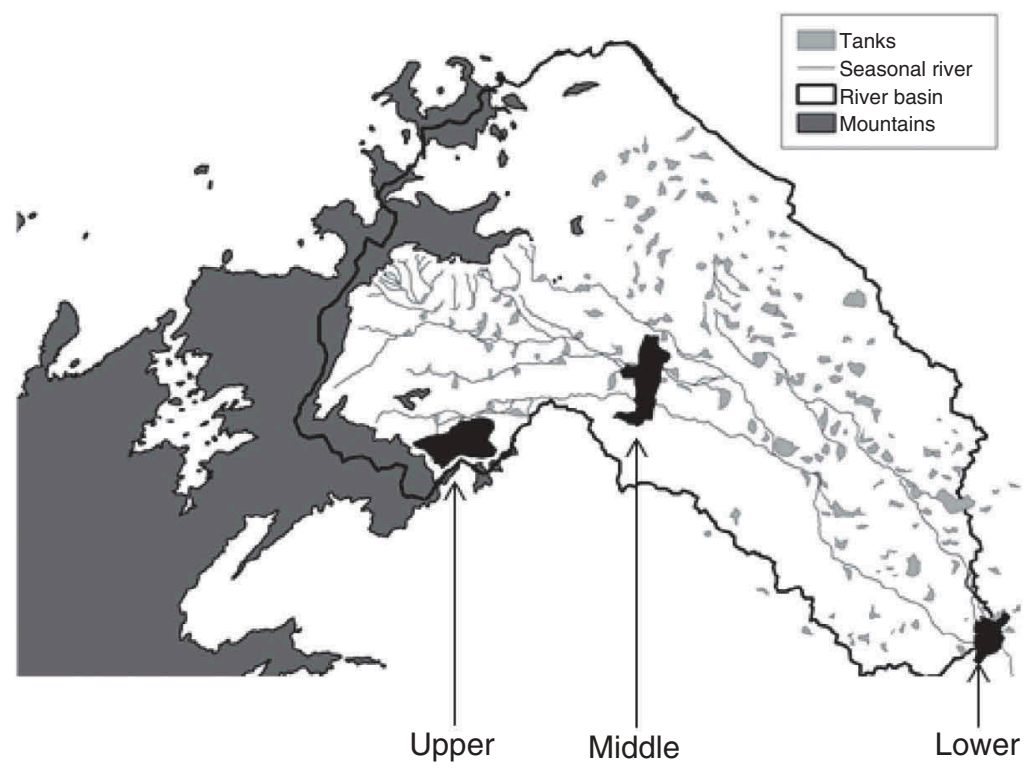

(b) Density of dug well

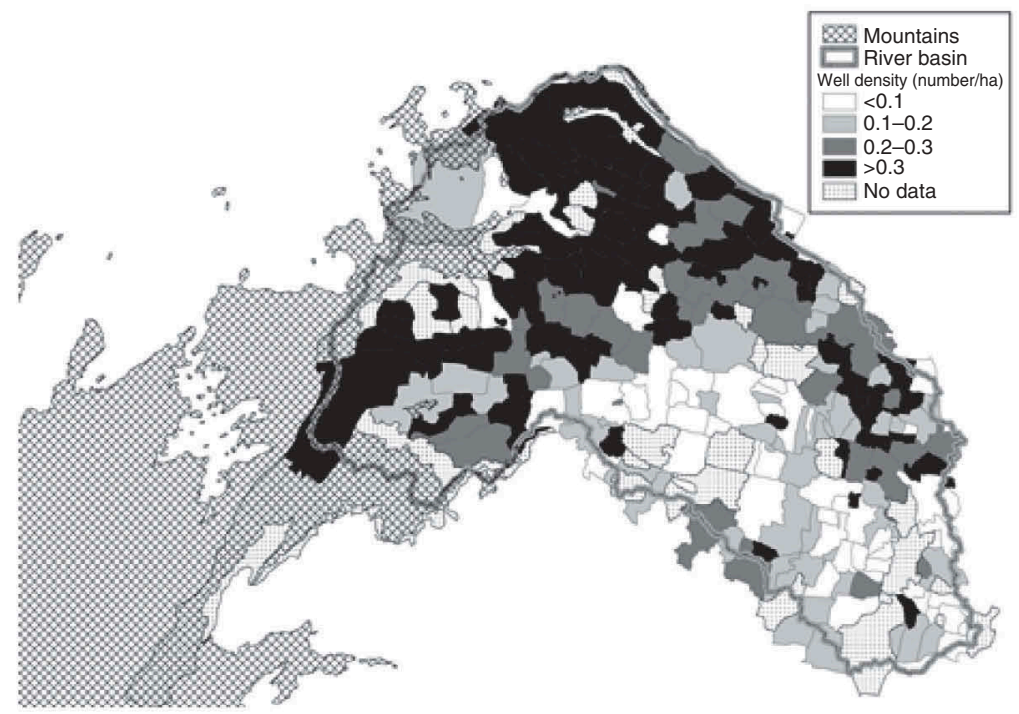

Map 10.3 Topography and Density of Dug Well in Upper Gundar River Basin, Tamil Nadu

Source: Prepared by author based on data from GOI (2013a). 


\subsection{Case of a farm village in Madurai District ${ }^{8}$}

Similar to Punjab, field surveys were conducted in a village (hereinafter, $\mathrm{S}$ village) located in a middle part of the upper Gundar River Basin. Table 10.3 presents basic characteristics of $S$ village, a large village with 964 households. The sizes of nanjai and punjai in this village are, respectively, 100.2 and 1,331.9 ha. Operational land holdings are not shown in this table because there is little difference with actual land holdings because of the inactive land rental market. As presented in Figures 10.6 and 10.7, the traditional cropping patterns, rice-millet cultivation in nanjai and millet-fallow in punjai, were dominant in 2008. The scale of millet cultivation after rice depends on the rainfall condition. According to interviews with farmers, current crop compositions were similar to those of 2008, although sugarcane cultivation decreased its share in nanjai.

Figure 10.8 presents the geological stratum and water balance of rice production in $\mathrm{S}$ village. Underground conditions in this village showed clear contrast with that in Punjab: gravel on soft and hard rock layers is com-

Table 10.3 Characteristics of S village, Madurai, Tamil Nadu

\begin{tabular}{|c|c|c|c|c|}
\hline \multirow{2}{*}{$\frac{\text { Items }}{\text { Total Number of Household }^{1}}$} & & & \multicolumn{2}{|l|}{ Number } \\
\hline & & & 964 & $(\mathrm{HH})$ \\
\hline Total Population ${ }^{1}$ & & & 3,395 & (people) \\
\hline \multirow[t]{2}{*}{ Total Agricultural Area ${ }^{2}$} & nanjai & & 100.2 & (ha) \\
\hline & punjai & & 1331.9 & (ha) \\
\hline \multirow[t]{2}{*}{ Average Land Holdings ${ }^{2}$} & nanjai & & 0.8 & (ha/HH) \\
\hline & punjai & & 1.64 & (ha/HH) \\
\hline \multirow[t]{8}{*}{ Cropping Pattern $^{2}$} & nanjai & Rice-Millet & 50 & $(\%)$ \\
\hline & & Rice-Fallow & 23.8 & $(\%)$ \\
\hline & & Sugarcane & 18.7 & $(\%)$ \\
\hline & & Others & 7.5 & $(\%)$ \\
\hline & punjai & Millet-fallow & 44.7 & $(\%)$ \\
\hline & & Fodder-fallow & 22.1 & $(\%)$ \\
\hline & & Fallow & 18.2 & $(\%)$ \\
\hline & & Others & 15 & $(\%)$ \\
\hline \multirow[t]{3}{*}{ Characteristics of well ${ }^{3}$} & & Depth of Dug Well & $12-18$ & $(\mathrm{~m})$ \\
\hline & & Depth of Inside Bore & 107 & $(\mathrm{~m})$ \\
\hline & & Depth of Delivery Pipe & 84 & $(\mathrm{~m})$ \\
\hline
\end{tabular}

Source:

${ }^{1}$ GOI (2013b).

2 Author's field survey in 2008.

3 Author's field survey in 2016. 


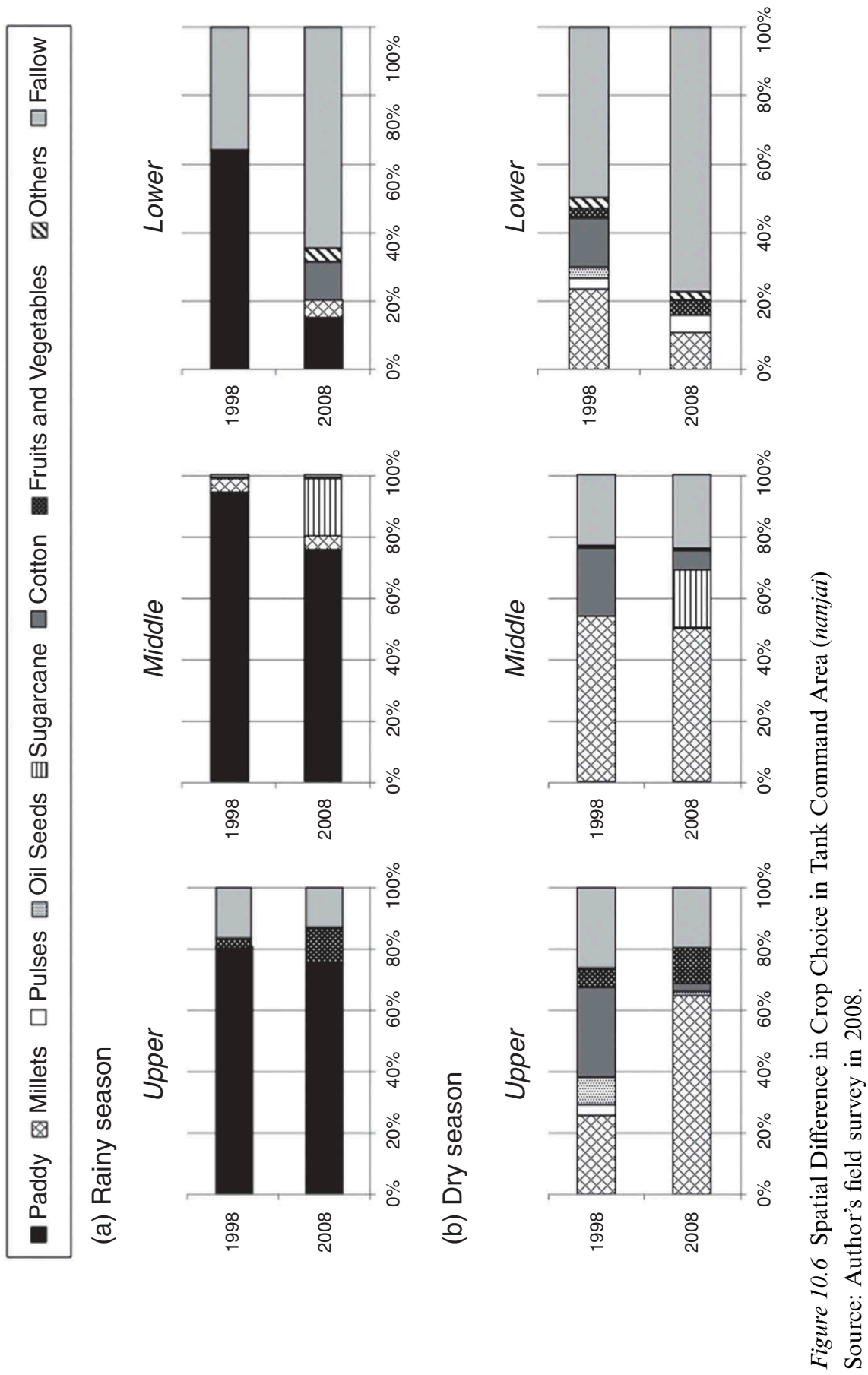




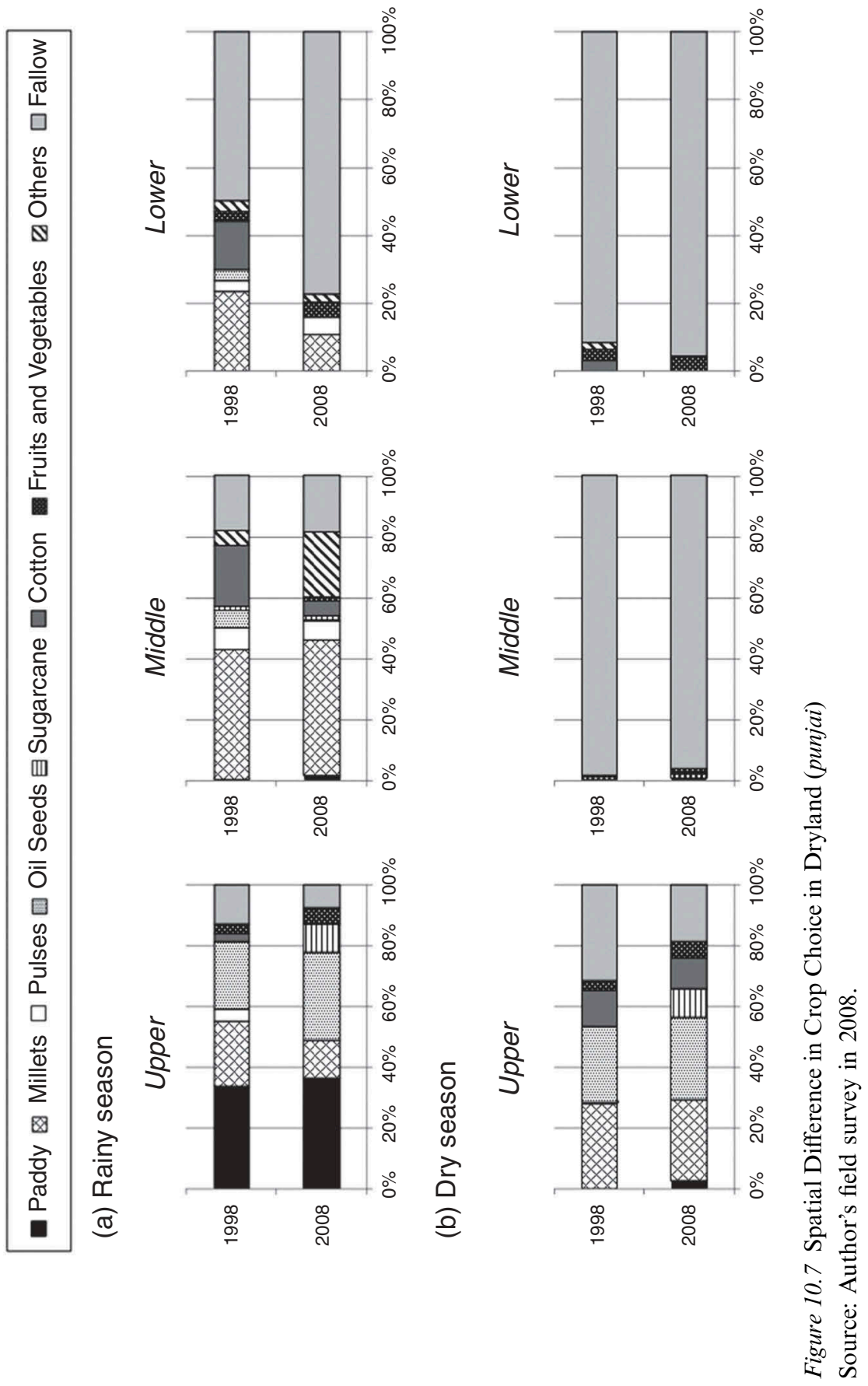




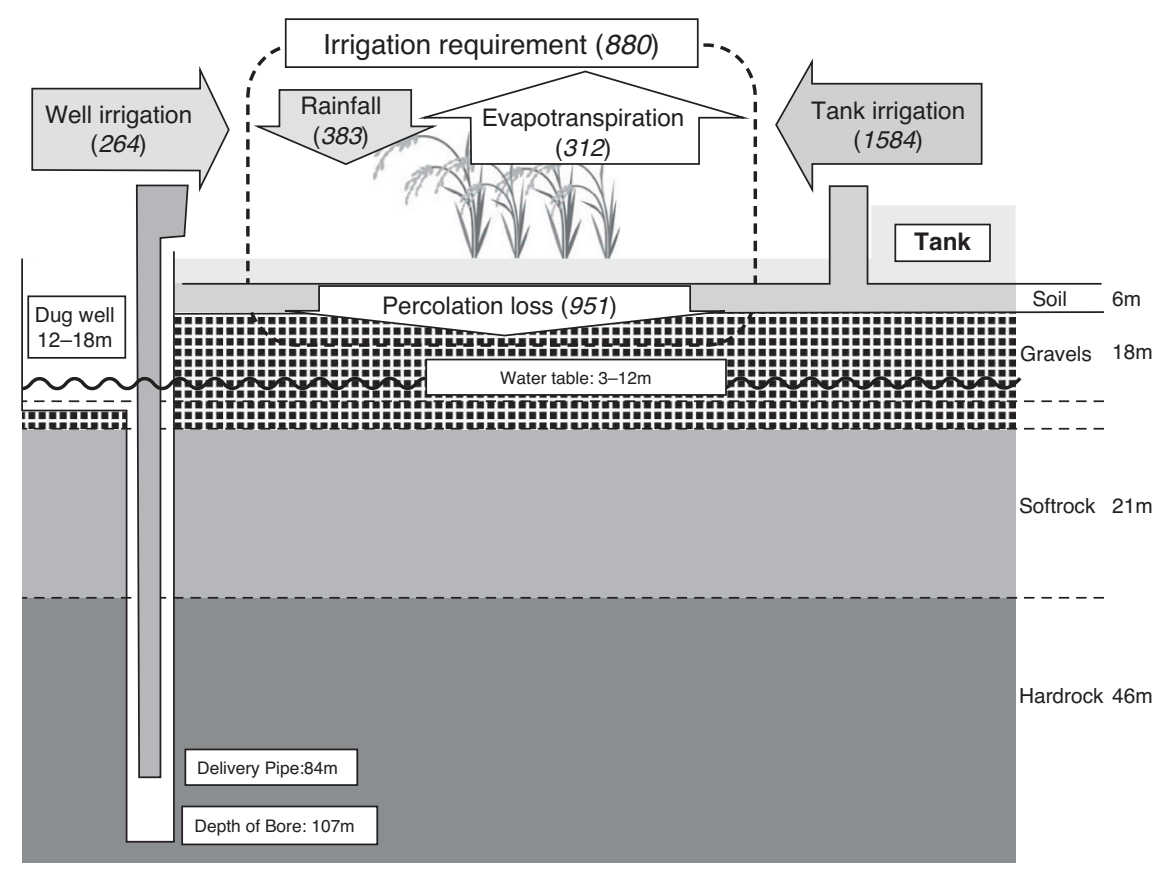

Figure 10.8 Geological Stratum and Water Balance in Rice Production in S Village, Tamil Nadu

Note: Numbers in brackets indicate water amount $(\mathrm{mm})$.

monly observed. ${ }^{9}$ Therefore, the groundwater holding capacity in this area is much lower than that in Punjab. The infiltrated water might move laterally to a dryer area, where the land surface is covered by crops other than paddy rice. Lateral water movements from paddy fields increase the percolation rate considerably (Tuong et al., 1994; Kukal and Aggarwal, 2002). The shallow water table was 3-12 m, depending on the season and the distance from tank. If the field is close to the tank, then the groundwater table becomes as high as $3 \mathrm{~m}$, but they usually cultivate rice only by tank irrigation. Farmers who have land far from a tank usually install a dug-cum-bore well, combining conventional dug wells with inside bore wells because the cost of dug-well digging (Rs.82,000/m) is much higher than that of bore well (Rs.206/m). The shallow water table rose when water is filled in the tank, which allows farmers to irrigate using a dug well. The maximum water depth in this tank command area during 1990-1998 was 7.25 m (Ford Foundation and Anna University, 2001), which reflects the decline of the water table since then. The traditional tank management system is still somewhat active in this village. Selected sluice operators and water distributors control the water supply in nanjai. Farmers irrigate their paddy fields 
using tank water or dug well water when the groundwater level is high. When the tank water is insufficient to irrigate the whole command area at the end of the season, the groundwater level drops. At such a time, they irrigate their fields using groundwater from inside the bore well for supplemental purposes. The average depths of the delivery pipe and bore were, respectively, $84 \mathrm{~m}$ and $107 \mathrm{~m}$. The delivery pipe depth is much greater than that in Punjab because they are pumping up groundwater stored in the secondary porosity in the rock layer, which does not exist homogeneously. Many farmers experienced failure of bore well digging (a dry bore well). Some farmers also install interior bore wells laterally to capture groundwater stored in a shallower layer close to a tank.

Evapotranspiration ${ }^{10}$ and percolation loss $^{11}$ during the rice cropping season are estimated respectively as being $312 \mathrm{~mm}$ and $951 \mathrm{~mm}$. The sum of these values $(1,263 \mathrm{~mm})$ shows the standard water requirement for paddy production in this village. It requires less water than Punjab because short duration varieties are used. Normal rainfall during this period is estimated as being $383 \mathrm{~mm} .{ }^{12}$ Therefore, it is necessary to irrigate $880 \mathrm{~mm}$ of water. When tank water is available, farmers irrigate their fields using more water than the crop requirement $\left(1,584 \mathrm{~mm}^{13}\right)$. At the end of the season, they irrigate groundwater from a bore well $(=264 \mathrm{~mm})$. Groundwater use in this case is much less than that of Punjab because of the existence of tanks.

Production and cost of rice production in Madurai are presented in Table 10.4. Gross income was Rs.79,080/ha, which is lower than that in Punjab because of the lower yield. Production costs accounted for Rs.45,173/ha, or 57.1 percent of the gross income. Costs for land preparation and transplanting were higher than in Punjab, reflecting the higher wage rate. Fertilizer and pesticide costs in this table include hand weeding costs. As a result, the net income from rice production in this area was Rs.33,907/ha, which was 15.2 percent lower than in Punjab.

As with Punjab, agricultural electricity is provided freely in Tamil Nadu. Until the approval of free electricity application, farmers with newly installed wells were charged Rs.3.5/kWh. The electricity cost for industrial purposes was charged at the rate of Rs.5.5/kWh in Tamil Nadu. Because of limited groundwater use for supplemental irrigation purposes, electricity costs were only 8.5 percent of gross income, even at the rate of industrial use. Therefore, the abolishment of a free electricity policy does not strongly affect current paddy production in the tank command area. However, maintenance and depreciation costs of well irrigation must be considered. As described already, most well owners experienced failures of well digging. The chance of success in digging depends on luck because of the heterogeneous distribution of secondary porosity. In the case of the Palar Basin in Tamil Nadu, each successful bore well requires at least five or six trial bores (Janakarajan and Moench, 2006). Costs of bore well digging (Rs.206/m) are 
Table 10.4 Production and Cost of Rice Production in Madurai, Tamil Nadu

\begin{tabular}{llll}
\hline Production & Yield (kg/ha) & 5,272 & \\
& Farm Gate Price (Rs./kg) & 15.0 & \\
& Gross Income (Rs./ha) & 79,080 & $(100 \%)$ \\
Input and Labor Cost & Land Preparation(Rs./ha) & 8,168 & \\
& Seed (Rs./ha) & 2,599 & \\
& Transplanting/Sowing (Rs./ha) & 12,129 & \\
& Fertilizer \& Pesticide (Rs./ha) & 17,079 & \\
& Harvesting (Rs./ha) & 5,198 & \\
Net income (Rs./ha) & Sub Total (Rs./ha) & 45,173 & $(57.1 \%)$ \\
& & 33,907 & $(42.9 \%)$ \\
Irrigation & & & \\
& & 264 & \\
& Groundwater amount (mm) & 1,222 & \\
& Electricity Use (kWh/ha) & 0 & \\
& Electricity Cost (Rs./ha) & 2,444 & $(3.1 \%)$ \\
& (with unit charge of 2 Rs./kWh) & $(5.4 \%)$ \\
& (with unit charge of 3.5Rs./kWh) & 4,276 & $(8.5 \%)$ \\
\hline & (with unit charge of 5.5Rs./kWh) & 6,720 & $\left(\begin{array}{l} \\
\end{array}\right.$ \\
& &
\end{tabular}

Source: Author's field survey in 2016.

much lower than those of dug wells, but they are expected to become higher than Rs.110,000 if five trial bores are used to dig up to $107 \mathrm{~m}$ below ground. Farmers must also pay for a pump-set for successful wells. Groundwater recharge in secondary porosity requires hundreds of years because of rock layer impermeability. Therefore, groundwater in the bore well is expected to dry up soon. Consequently, dependence on such "fossil groundwater" might increase the maintenance and depreciation costs of well irrigation. It is unsustainable, not only from an economic viewpoint, but from an environmental viewpoint.

\section{Discussion}

Both Punjab and Tamil Nadu are known as states in which the Green Revolution has been most successful. The increments of rice and wheat production in these two states have contributed greatly to the achievement of national food self-sufficiency. Expansion of groundwater irrigation led such agricultural development, but it currently endangers agricultural sustainability in both states.

In the case of Punjab, expansion of groundwater irrigation enhanced land use changes toward rice-wheat monoculture (Figure 10.2). Farmers enjoy the benefits of free electricity policy and minimum support prices. They have also secured substantial incomes from rice production, even though 
land rent accruing to non-resident landowners accounts for a large share among all production costs. Early signs of groundwater overdraft were observed clearly in Punjab, causing a continuous decline of the water table (Vatta, 2015). However, excess use of groundwater irrigation, which is 50.7 percent more than actual irrigation water requirements (Figure 10.3), might continue because the installation of automatic switches allows farmers to irrigate their fields whenever electricity is available.

What kinds of government intervention can support the sustainability of groundwater-irrigated agriculture in Punjab? Changes in cropping patterns demanding less water have been attempted by the state government, but they have not been implemented because they are not economically feasible in Punjab given the existing yields and pricing mechanisms (Sarkar and Das, 2014). How about the introduction of the solar irrigation pump, the project of which was launched in Rajastern in 2011? Kishore et al. (2014) reported that it will increase water productivity but that it will not contribute to water conservation. Considering both the environmental and economical sustainability of groundwater-irrigated agriculture in Punjab, top-down control of the agricultural electricity supply might be the only solution for sustainable groundwater use: 'Jyotigram Yojana' (JGY) launched in Gujarat in 2003 (Shah, 2008b; Chindarkar, 2017). The aim of JGY was to increase the reliability and accessibility of grid electricity in rural areas by separating agricultural and non-agricultural transmission lines. Actually, JGY guaranteed 24/7 three-phase electricity for non-agricultural consumption, and eight uninterrupted hours of pre-scheduled three phase electricity to agricultural consumers (Chindarkar, 2017). Once agricultural and non-agricultural transmission lines are separated, the state electricity board can control the electricity supply for agricultural purposes at the substation level. Combined with agricultural land use planning, the introduction of JGY is expected to provide state government with control of groundwater use via the electricity supply. In the case of Gujarat, the groundwater level is recovering by JGY introduction. Farmers have become able to keep their irrigation schedules, conserve water, save on pump maintenance costs, use labor more efficiently, and expand their irrigated agriculture rapidly (Bird et al., 2014). Because rural households constitute a large voter base in India, abolishment of free electricity policies might be untenable from a political viewpoint. Introduction of a scheme such as JGY might be the only solution for designing sustainability of groundwater-irrigated agriculture in areas with alluvial soils.

Case studies of Tamil Nadu presented in this chapter provide a different perspective on sustainability of groundwater-irrigated agriculture in hard rock areas. Even though well-irrigated agriculture expanded at the district level, it caused a decline of cropping areas because of limited groundwater potential in this area. Only farmers at the upper part of the basin enjoyed the benefits of groundwater irrigation. Farmers in the lower part of the basin faced irrigation water deficits and abandoned their agricultural practices (Map 10.3, Figures 10.6 and 10.7). It is the nature of water to run 


\section{0}

downhill. Therefore, farmers in the upper part of the basin physically have priority for water access compared to those in the lower part of the basin. Moreover, the groundwater flow direction in the study area more or less follows the general land surface slope (Thiyagarajan et al., 2006). For that reason, well concentrations in the upper part of the basin can reform the water cycle of this river basin. The traditional water cycle based on the tank irrigation system has delivered substantial amounts of surface water to the lower basin. However, not only surface water but also groundwater is used extensively in the upper part of the basin after the introduction of groundwater irrigation, and only a limited amount of surface/ground water flows downward. As a result, considerable differences in farm income were observed between upper and lower parts of the basin (Sato and Periyar, 2011), although invasive tree species on abandoned farmland have provided some temporary benefit in the lower part of the basin (Sato, 2013).

A case study in the selected village of the central basin clearly indicated the importance of tank irrigation in this area because the dependence on deep groundwater is not feasible from either environmental or economic perspectives. Tank irrigation systems have deteriorated, especially since the 1990s (Janakarajan, 1993; Kajisa et al., 2007), because of several factors: priority to major and medium surface irrigation projects and groundwater, heavy silting of the tank and feeder channels, encroachment on the tank foreshore area, deforestation in the catchment area, poor functioning of tank sluices, defective tank structures, and weak farmers' organizations (Palanisami, 1990). Such a decline of tanks can be attributed to a loss of farmers' interest in tank management (Sharma, 2003) resulting from the expansion of well irrigation in the tank command (Janakarajan, 2003) and from permanent/temporary migration to urban areas (Sato, 2011). Collective tank management cannot be expected under such circumstances. Numerous tanks are already defunct (Palanisami et al., 2010). Such a trend of deterioration might continue into the future.

Even when tanks do not supply surface irrigation, they can still contribute through use as percolation ponds for shallow dug wells by closing sluices permanently. Such conversion has proved to have some economic benefit (Palanisami et al., 2010), and is already in practice in some villages (Janakarajan and Moench, 2006). For sustainable use of groundwater irrigation in the tank command area, continuous maintenance work is required. Although collective management cannot be expected, tanks have been managed under the Mahatma Gandhi National Rural Employment Guarantee Act (MGNREGA) since 2009. Such management includes activities such as desilting and renovation of existing tanks. Several scholars have reported positive effects on well performance in the tank commands (Deivalatha and Ambujam, 2011; Tiwari et al., 2011; Esteves et al., 2013). Such government intervention in the maintenance of tank irrigation systems is expected to sustain groundwater-irrigated agriculture in this area. 
The groundwater revolution started from the 1970s throughout India. It was encouraged by provision of institutional finance, investment in rural electrification, and subsidized provision of credit and energy (Vaidyanathan, 2008). As presented in this report, current groundwater-irrigated agriculture can be sustained only through institutional intervention that considers local hydrological characteristics. Policy and technologies must be designed not only for shortterm economic gain, but also for environmental sustainability in the long run.

\section{Summary and conclusion}

Sustainability of groundwater-irrigated agriculture in Punjab and Tamil $\mathrm{Nadu}$ was investigated based on the statistical data and fieldwork in the sample villages. Agriculture in Punjab, which has high groundwater potential with alluvial soil layer, has intensified along with expansion of well irrigation. Rice-wheat monoculture is currently dominant. Enjoying the benefits of free electricity policy and minimum support prices, high profitability of rice production is widely apparent in Punjab. However, expansion of well irrigation in Tamil Nadu, which has low groundwater potential because of its hard rock layer, has not contributed to agricultural intensification. Crop conversion from traditional coarse grain to fruits and vegetables requiring timely irrigation was observed only in villages of the upper basin. Crop cultivation in the middle and lower basin remained constant or declined because of changes in the water cycle at the basin level. A case study of villages of the central basin revealed the importance of tank irrigation for their rice production.

Because of the different hydrogeological characteristics in these states, different policy recommendations can be proposed in pursuit of groundwater-irrigated agriculture sustainability. Irrigation and energy issues are tightly interconnected in Punjab. Therefore, government intervention to control agricultural electricity use such as 'Jyotigram Yojana' (JGY) might be effective. For Tamil Nadu, groundwater-irrigated agriculture is not sustainable without establishing an artificial structure of groundwater recharge. Considering the current status of tank irrigation systems, converting tanks to percolation ponds with maintenance through the Mahatma Gandhi National Rural Employment Guarantee Act (MGNREGA) might be effective. In conclusion, institutional design considering local hydrogeological conditions is fundamentally important for the sustainability of groundwaterirrigated agriculture in India.

\section{Notes}

1 Field surveys in these villages were conducted in December 2015, July 2016, and March 2017. 
2 Total costs of a tube well include bore digging and the pump-set. Costs of bore digging up to $95 \mathrm{~m}$ were Rs.78,750 (Rs.82/m). The submersible pump-set with $12.5 \mathrm{HP}$ costs around Rs.35,000.

3 Based on an interview of a Punjab well digger conducted in July 2016.

4 It was estimated using the method proposed by Allen et al. (1998) with average monthly PET data in Ludhiana district (ICRISAT, 2015).

5 Percolation loss from paddy field depends on soil type, puddling intensity, ponding depth, etc. In this study, the percolation loss was estimated using the value of $9 \mathrm{~mm} /$ day, which was proposed by Khepar et al. (1999) based on the studies in Punjab Agricultural University.

6 This was estimated using the normal rainfall amount in Ludhiana district (ICRISAT, 2015).

7 Field measurements were taken in July 2016. The amount of groundwater extracted with a $12.5 \mathrm{HP}$ pump-set was estimated as $3.04 \mathrm{~mm} / \mathrm{h}$. This value is multiplied by the total irrigation hours (616 hours) during the rice cultivation period. Farmers irrigate their fields every day from June 10. Then the irrigation frequency will decrease to once in every 2-3 days until the middle of October.

8 Field surveys were conducted in this village in March and October, 2016.

9 Based on an interview conducted with a well digging company.

10 It was estimated using the method proposed by Allen et al. (1998) with average monthly PET data in Madurai district (ICRISAT, 2015).

11 Percolation loss in Figure 10.11 was estimated from the interview and field measurement. Most farmers mentioned that ponded water disappears in 3 days. The pumpset with 5HP was commonly used in this village. The amount of one-time irrigation was estimated as $52.8 \mathrm{~mm}$ from field measurements conducted in October 2016. Therefore, the daily amount of percolation loss and evaporation can be estimated as $17.6 \mathrm{~mm}$. The average daily evapotranspiration during the rice growing period was estimated as $4.2 \mathrm{~mm}$. The daily percolation rate of $13.4 \mathrm{~mm} /$ day can be obtained from these values. It was multiplied with the period of irrigation (71 days), and finally obtains the percolation loss as $951 \mathrm{~mm}$.

12 As estimated using the normal rainfall amount in Madurai district (ICRISAT, 2015).

13 The amount of tank irrigation was estimated by multiplying the one-time irrigation amount $(52.8 \mathrm{~mm})$ by the total irrigation repetitions (30 times).

\section{References}

Allen, R. G., L. S. Pereira, D. Raes, and M. Smith (1998). “Crop Evapotranspiration: Guideline for Computing Crop Water Requirements," FAO Irrigation and Drainage Paper 56, Rome: FAO.

Amarnath, J. S. and P. K. Raja (2006). "An Economic Analysis of Tank Rehabilitation in Madurai District of Tamil Nadu," Agricultural Economics Research Review, vol. 19, pp. 187-94.

Bird, J., F. Dodds, P. G. McCornic, and T. Shah (2014). "Water-Food-Energy Nexus," Water for Food Faculty Publications 4.

Bobba, A. G., V. P. Singh, and L. Bengtsson (1997). "Sustainable Development of Water Resources in India,” Environmental Management, vol. 21, pp. 367-93. 
Center for Education and Documentation (2010). Impact of Climate Change on Arid Regions in India. [Online] Available at http://base.d-p-h.info/fr/fiches/dph/fiche-dph8611.html (accessed on September 9, 2017).

Chindarkar, N. (2017). "Beyond Power Politics: Evaluating the Policy Design Process of Rural Electrification in Gujarat, India," Public Administration and Development, vol. 37 , pp. $28-39$.

Deivalatha, A. and N. K. Ambujam (2011). "Sustainable Agriculture Productivity through Restoration of Tank Irrigation System with Stakeholder Decision: Case Study in Rural Tank Ecosystem," International Journal of Biodiversity and Conservation, vol. 3(11), pp. 527-39.

Dhawan, B. D. (1975). "Economics of Groundwater Utilization: Traditional versus Modern Techniques," Economic and Political Weekly, vol. 10(25\&26), pp. 31-42.

Dhawan, B. D. (1993). "Groundwater Depletion in Punjab," Economic and Political Weekly, vol. 28(44), pp. 2397-401.

Esho, H. (2008). Ririku shita Indo Keizai: Kaihatsu no Kiseki to Tenbo [in Japanese: Indian Economy Has Taken Off: Track and Prospects of Development], Kyoto: Minerva Syobo.

Esteves, T., K. V. Rao, B. Sinha, S. S. Roy, B. Rao, S. Jha, A. B. Singh, P. Vishal, S. Nitasha, S. Rao, I. K. Murthy, R. Sharma, I. Porche, K. Basu, and N. H. Ravindranath (2013). "Agricultural and Livelihood Vulnerability Reduction through the MGNREGA," Economic and Political Weekly, vol. 48(53), pp. 94-103.

Ford Foundation and Center for Water Resources in Anna University (2001). Participatory Rehabilitation and Management in Sowdarapatti Tank, Chennai: Anna University.

Francis, W. (1906). Madras District Gazetteers: Madura, Chennai: Madras Government Press.

Government of India (2013a). Minor Irrigation Census Fourth Census (2006-07) [Online] Available at https://data.gov.in/keywords/minor-irrigation-census (Accessed on August 17, 2017).

Government of India (2013b). Primary Census Abstract Data Tables, Census of India, Government of India. [Online] Available at http://censusindia.gov.in/pca/pcadata/ pca.html (Accessed on December 6, 2016).

Government of Tamil Nadu (GOTN) (1970). Tamil Nadu: An Economic Appraisal, Madras: Finance Department.

Government of Tamil Nadu (GOTN) (2009). Gundar River Basin, Chennai: A report of Public Works Department.

ICRISAT (International Crops Research Institute for the Semi-Arid Tropics) (2015). Meso Level Data for India: 1966-2011, Collected and Compiled under the Project on Village Dynamics in South Asia, Pattancheru, Telangana, India.

Janakarajan, S. (1993). "In Search of Tanks: Some Hidden Facts," Economic and Political Weekly, vol. 28(26), pp. 53-60.

Janakarajan, S. (2003). "Need to Modernize the Tradition: Changing Role of Tanks in Response to Scarcity and Variability," In Proceedings of the Conference on Market Development of Water and Water Technologies through Environmental Economics, 30-31 October, 2003, Delhi. 
Janakarajan, S. and M. Moench (2006). “Are Wells a Potential Threat to Farmers' Well-being? Case of Deteriorating Groundwater Irrigation in Tamil Nadu," Economic and Political Weekly, vol. 41(37), pp. 3977-87.

Kajisa, K., K. Palanisami, and T. Sakurai (2007). "Effects on Poverty and Equity of the Decline in Collective Tank Irrigation Management in Tamil Nadu, India," Agricultural Economics, vol. 36, pp. 347-62.

Khepar, S. D., S. K. Sondhi, and S. Kumar (1999). "Impact of Cultural Practices on Water Use in Paddy Fields," ICSD Journal, vol. 48(3), pp. 13-26.

Kishore, A., T. Shah, and N. P. Tewari (2014). "Solar Irrigation Pumps: Farmers' Experience and State Policy in Rajasthan," Economic and Political Weekly, vol. 50(10), pp. 55-62.

Kukal, S. S. and G. C. Aggarwal (2002). "Percolation Losses of Water in Relation to Puddling Intensity and Depth in a Sandy Loam Rice (Oriza Sativa) Field," Agricultural Water Management, vol. 57(1), pp. 49-59.

Leck, H., D. Conway, M. Bradshaw, and J. Rees (2015). "Tracing the Water-EnergyFood Nexus: Description, Theory and Practice," Geography Compass, vol. 9(8), pp. 445-60.

Mosse, D. (2003). The Rule of Water: Statecraft, Ecology, and Collective Action in South India, New Delhi: Oxford University Press.

Mukherjee, A., D. Saha, C. F. Harvey, R. G. Taylor, K. M. Ahmed, and S. N. Bhanja (2015). "Groundwater Systems of the Indian Sub-Continent," Journal of Hydrology: Regional Studies, vol. 4, pp. 1-14.

Olson, D. M., E. Dinerstein, E. D. Wikramanayake, N. D. Burgess, G. V. N. Powell, E. C. Underwood, J. A. D'Amico, I. Itoua, H. E. Strand, J. C. Morrison, C. J. Loucks, T. F. Allnutt, T. H. Ricketts, Y. Kura, J. F. Lamoreux, W. W. Wettengel, P. Hedao, and K. R. Kassem (2001). "Terrestrial Ecoregions of the World: A New Map of Life on Earth," BioScience, vol. 51, pp. 933-38.

Palanisami, K. (1990). "Tank Irrigation in South India: What's Next?," ODI/IIMI Irrigation Management Network Paper 90/2e.

Palanisami, K. (2000). Tank Irrigation: Revival for the Prosperity, New Delhi: Asian Publication Services.

Palanisami, K., R. Meinzen-Dick, and M. Giordano (2010). "Climate Change and Water Supplies: Options for Sustaining Tank Irrigation Potential in India," Economic and Political Weekly, vol. 45(26\&27), pp. 183-90.

Palanisami, K., A. Vidhyavathi, and C. R. Ranganathan (2008). "Wells for Welfare or 'Illfare'? Cost of Groundwater Depletion in Coimbatore, Tamil Nadu, India," Water Policy, vol. 10, pp. 391-407.

Rao, A. V. R. K., S. P. Wani, K. K. Singh, M. I. Ahmed, K. Srivivas, S. B. Bairagi, and O. Ramadevi (2013). "Increased Arid and Semi-arid Areas in India with Associated Shifts during 1971-2004,” Journal of Agrometeorology, vol. 15(1), pp. 11-18.

Sarkar, A. and A. Das (2014). "Groundwater Irrigation-Electricity-Crop Diversification Nexus in Punjab: Trends, Turning Points and Policy Initiatives," Economic and Political Weekly, vol. 49(52), pp. 64-73.

Sato, K. (2011). "Employment Structure and Rural-Urban Migration in a Tamil Nadu Village: Focusing on Differences by Economic Class," Southeast Asian Studies, vol. 49(1), pp. 22-51.

Sato, T. (2013). "Beyond Water-Intensive Agriculture: Expansion of Prosopis Juliflora and Its Growing Economic Use in Tamil Nadu, India," Land Use Policy, vol. 35, pp. 283-95. 
Sato, T. (2016). "Evolution of Water-Intensive Agriculture from 1909/10 to 2009/10 in Tamil Nadu, India: The Case of Madura District," Paper presented at the TNAUINDAS International Conference "Toward Sustainable Development of India and South Asia: Population, Resources, and Environment”, 1-2 March, 2016, Tamil Nadu Agricultural University, Coimbatore.

Sato, T. and R. D. Periyar (2011). "The Effects of Expansion of Private Wells on Rural Livelihood in Tank Intensive Watersheds: A Case Study in Upper Gundar River Basin, Tamil Nadu," Southeast Asian Studies, vol. 49(1), pp. 124-50.

Shah, T. (2008a). Taming the Anarchy: Groundwater Governance in South Asia, Washington DC: Routledge.

Shah, T. (2008b). "Groundwater Governance through Electricity Supply Management: Assessing an Innovative Intervention in Gujarat, Western India," Agricultural Water Management, vol. 95, pp. 1233-42.

Shah, T. (2008c). "India's Master Plan for Groundwater Recharge: An Assessment and Some Suggestions for Revision," Economic and Political Weekly, vol. 48(51), pp. 41-49.

Sharma, A. (2003). "Rethinking Tanks: Opportunities for Revitalizing Irrigation Tanks. Empirical Findings from Anathapur District, Andhra Pradesh, India," International Water Management Institute Working Paper 62.

Singh, N. T. (2005). Irrigation and Soil Salinity in the Indian Subcontinent: Past and Present, Bethlehem: Lehigh University Press.

Sivasubramaniyan, K. (2006). "Sustainable Development of Small Water Bodies in Tamil Nadu," Economic and Political Weekly, vol. 41(26), pp. 2854-63.

Smajgl, A., J. Ward, and L. Pluschke (2015). "The Water-Food-Energy Nexus: Realizing a New Paradigm," Journal of Hydrology, vol. 533, pp. 533-40.

Sugimoto, D. and Y. Usami (2014). "Punjab," In Yanagisawa, H. and T. Mizushima eds., Gekidou No Indo Volume 4. Nougyo to Noson [in Japanese: Agriculture and Rural Area], Tokyo: Nihon Keizai Hyoronsya, pp. 127-87.

Suhag, R. (2006). Overview of Ground Water in India, PRS Legislative Research. [Online] Available at: https://www.prsindia.org/policy/discussion-papers/overviewground-water-india

Thiyagarajan, G. M., V. Ranghaswami, and R. Umadevi (2006). "Groundwater Flow Modelling in Gundar River Basin, Tamil Nadu," Asian Journal of Water, Environment and Pollution, vol. 4(1), pp. 199-202.

Tiwari, R., H. I. Somashekhar, V. R. P. Ramakrishnama, I. K. Murthy, M. S. Mohan Kumar, B. K. Mohan Kumar, H. Parate, M. Varma, S. Malaviya, A. S. Rao, A. Sengupta, R. Kattumuri, and N. H. Ravindranath (2011). "MGNREGA for Environmental Service Enhancement and Vulnerability Reduction: Rapid Appraisal in Chitradurga District, Karnataka," Economic and Political Weekly, vol. 46(20), pp. 39-47.

Tuong, T. P., M. C. S. Wopereis, J. A. Marquez, and M. J. Kropff (1994). "Mechanisms and Control of Percolation Losses in Irrigated Puddle Rice Fields," Soil Science Society of America Journal, vol. 58, pp. 1794-803.

Vaidyanathan, A. (2008). India's Water Resources: Contemporary Issues on Irrigation, New Delhi: Oxford University Press.

Vatta, K. (2015). "Sustainability of Groundwater Use in Punjab Agriculture: Issues and Options," Paper presented at The 28th Annual Conference of Japanese Association for South Asian Studies, 26-27 September, 2015, Tokyo: The University of Tokyo. 


\title{
11 Farm power policies and groundwater markets
}

\author{
Contrasting Gujarat with West \\ Bengal (1990-2015) ${ }^{1}$
}

\author{
Tushaar Shah
}

LEMERITUS SCIENTIST, INTERNATIONAL WATER MANAGEMENT INSTITUTE

\section{Sujata Das Chowdhury}

INDEPENDENT RESEARCHER

Ubiquity and pervasive presence of village-level, decentralized markets for irrigation services based on groundwater have been the hallmark of irrigation growth in South Asia since the 1970s. The numbers of privately owned and managed mechanized water extraction mechanisms (WEMs) have increased from less than 100,000 before 1950 to an estimated over 32 million in the plains of South Asia. Thanks to the emergence of vibrant, though informal and decentralized, village-level groundwater markets, private WEMs have together brought far more land under supplemental on-demand irrigation than government canals could do in more than 200 years of canal construction. Groundwater irrigation also emerged ubiquitous and 'democratic'; while benefits of public irrigation projects remained confined to command areas, WEMs reached irrigation benefits to the nooks and corners of the subcontinent.

In the beginning of the mid-1980s, there emerged a growing corpus of empirical research which has closely studied the working of water markets as economic institutions with particular emphasis on their productivity, equity and environmental impacts. During those early years, some researchers pejoratively referred to 'water sellers' as 'water lords' because they were charging high profits for doling out groundwater, a common property resource (Fujita, 2004). Many public tube well programs, which sought to offer irrigation services at heavily subsidized rates, put into bold relief the large margin between the water price charged by private water sellers $(\mathrm{W})$ and their average cost of delivering the service (AC). An interesting proposition in currency was to reduce the W/ AC multiple from 3.5-4 prevalent in many areas to close to 1, and this could impel private water sellers to operate as if they were public tube well programs, and thus far more efficiently.

Later studies progressively added nuance to this growing literature, which recognized the vast benefits that accrued to marginal farmers and tenants who gained access to quality irrigation service through water markets (Pant, 
1991; Shah, 1993; Mandal, 2000). Much research since then has concentrated on understanding the terms of transactions between water sellers and buyers and their impacts in terms of efficiency, equity, and socioecological sustainability.

At the heart of this exploration is the relationship between energy pricing for groundwater pumping and the behavior of water sellers. Shah (1987, 1993) explored the role of energy policies in determining W/AC multiple in some detail. Positing a village groundwater market as a 'natural oligopoly', Shah (1993: 210) suggested that increasing the density of WEMs in a village is a slow route to increasing competition among water sellers, reining in their monopoly power and whittling down the W/AC multiple. However, an even quicker and stronger route to turning these oligopolies into competitive water markets would be to charge electric tube wells affordably high flat tariffs instead of pro-rata tariffs (Shah, 1993), as many electricity utilities were already doing. Shah alerted that flat power tariff would benefit resource-poor water buyers but would threaten the sustainability of groundwater and strain the finances of electricity utilities. It was argued that both of these could be controlled by rationing farm power supply and periodically revising the flat tariff to cover the cost-to-serve power to farmers (Shah, 1993).

In India, this debate has become even more interesting because of the energy divide in the groundwater economy. In western India, from Punjab down to Tamil Nadu, electric pumps supported by free or subsidized electricity have dominated the groundwater irrigation economy. In contrast, in eastern India, dogged by poor rural power supply networks and insufficient power generation, groundwater irrigation has been constrained by high and rising prices of diesel and low rates of WEM electrification (Shah et al., 2008). In western India, power subsidies helped broaden irrigation access to the poor by catalyzing competitive water markets. However, gradually, groundwater over-exploitation and growing power subsidies led to the search for solutions to strike a balance between irrigation and socioecological sustainability. In eastern India, endowed with abundant groundwater resources, high water prices constrained irrigation expansion and agricultural growth. Socio-economic researchers contributed in analyzing these trade-offs. Policymakers in Gujarat in the west and West Bengal in the east actively used this research to amend their policies. The next two sections offer a broad review of a slew of studies that followed to examine the impact of these policies since 2000 .

\section{Farm power rationing under Jyotigram in Gujarat}

Following sustained farmer agitations for farm power tariff reforms, the Government of Gujarat introduced a new flat tariff system in 1988 under which meters were abolished and farmers were subject to a progressive flat electricity tariff. In the immediate aftermath, this produced major beneficial 


\section{8}

Tushaar Shah and Sujata Das Chowdhury

productivity and equity impacts on smallholder irrigation. Since the marginal cost of electricity to tube well owners was reduced to zero, they were induced to aggressively sell water to their neighbors, typically marginal farmers and sharecroppers unable to afford their own tube wells. Competition among sellers pared prices of pump irrigation service in local informal water markets, greatly benefiting the poor. Flat tariff also resulted in massive increases in demand for tube well electricity connections and expansion in groundwater irrigation, and increased the utilization of tube wells. Flat tariff reduced the Gujarat Electricity Board's (GEB) transaction cost of metering and billing a million dispersed electric tube well connections, but it greatly increased their agricultural load, which mounted their losses. Researchers had argued that flat tariff must be accompanied by vigorous rationing of farm power supply to contain subsidies and groundwater overexploitation (Shah, 1993).

As farm power subsidies mounted and groundwater over-draft grew, the government tried to gradually reduce power supply to agriculture. During the 1980s, farmers got 18-20 hours of three-phase electricity/day. This came down to 10-12 hours by the turn of the millennium. The quality and timing of rural power supply deteriorated, too. Power supply came with low voltage, often during the nights and with frequent tripping that damaged motors. The poor and inadequate power supply to agriculture became the key issue in Gujarat's mass politics (Shah and Verma, 2008: 59-60; for background see Shah et al., 2004).

Poor quality of power supply hit the quality of rural life as well. Normally, two-phase power that can run domestic appliances was provided 24 hours but three-phase power required to operate tube wells, grain mills, and other heavy equipment was restricted to 10-12 hours. To beat this system, farmers began using capacitors (locally called tota) to convert two - or even single phase power-into three-phase power to run their tube wells. This reduced the voltage downstream affecting the village community while tube wells continued to operate unhindered for 18-20 hours per day. The rural society and its nonfarm economy were held hostage by the burgeoning groundwater economy of Gujarat. Power engineers consider capacitors to be the gateway to improved power factor ( $\mathrm{pf})^{2}$; but in rural Gujarat, farmers turned these into an instrument for power theft (Shah and Verma, 2008: 60).

The way out of this imbroglio, it was commonly argued, was to meter tube wells, improve the amount and quality of power supplied to farmers, and charge metered tariffs. However, the threat of reforms on these lines had lost chief ministers elections in Andhra Pradesh, Madhya Pradesh, and Kerala. Instead of embracing such political 'hara-kiri', Shah et al. (2004) had argued for a second-best solution of 'intelligent rationing' of power supply for tube wells in a way that mimics a high-performing canal irrigation system. Key elements of their policy proposals were: (i) farmers should be provided sufficient power during 40-50 days per year of peak irrigation demand, but it must be strictly rationed on other days; (ii) flat tariff should 
be raised gradually to cover the average cost of power; (iii) off-peak night power should be used to keep the average cost of farm power supply low; (iv) intelligent scheduling and management should be used as a strategy for effective co-management of groundwater and electricity use in agriculture; (v) farmers' resistance to power rationing should be overcome by enhancing the predictability and reliability of power supply, by improving the quality in terms of voltage and frequency, and minimizing tripping, and better matching of power supply during peak periods of moisture stress.

In the early years of the millennium, Chief Minister Narendra Modi found that the only way to realize his promise of $24 \times 7$ rural power supply was by tamper-proof rationing of farm power supply (Shah and Verma, 2008: 60). So, during 2003-06, in a 1,000-day campaign called Jyotigram (lighted village), the Government of Gujarat and Gujarat Urja Vikas Nigam Limited (GUVNL) rewired the rural electricity grid in 18,000 villages, investing $\$ 250$ million in such a way that all tube wells were put on exclusive agricultural feeders while all other rural consumers were connected to Jyotigram feeders (see Figure 11.1 in Shah and Verma, 2008: 60). After this, a tight system of eight-hourly farm power ration was instituted on the agricultural feeder, while Jyotigram feeder began receiving $24 \times 7$ three-phase power. A statewide roster of farm-power

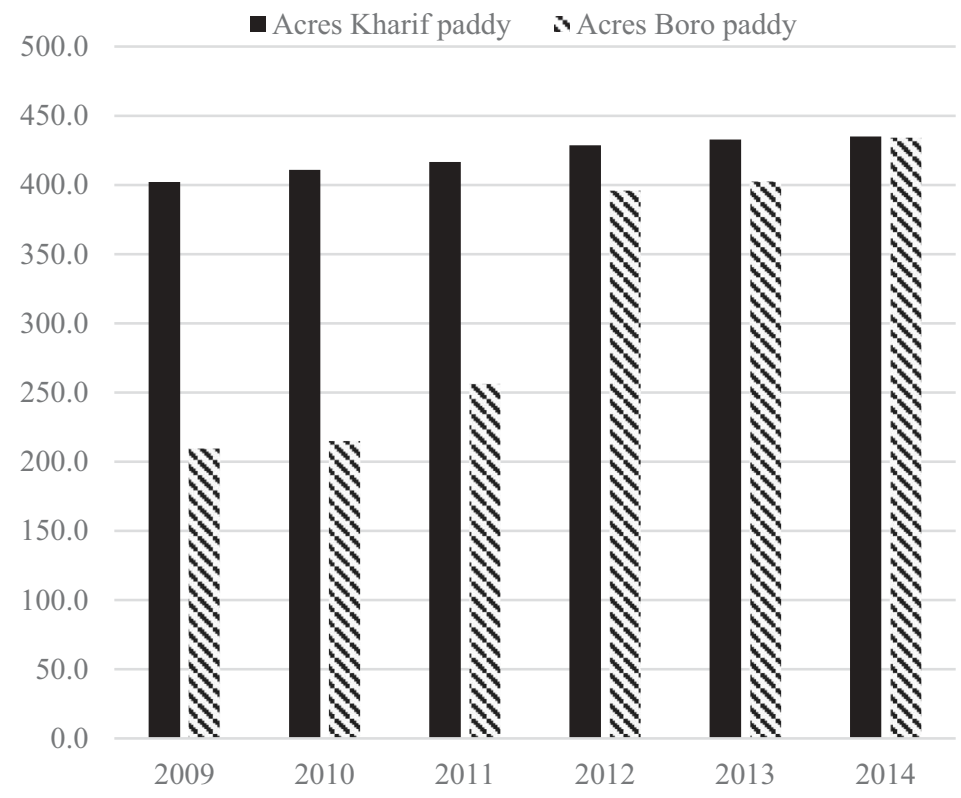

Figure 11.1 Increase in Amon and Boro Paddy Area of 146 Sample Farmers in 5 Survey Villages

Source: Das Chawdhury, 2015. 
supply was established under which each village received its power ration during daytime one week and during the night the next week. Farmers now received fewer hours of daily power supply but the voltage improved, interruptions declined and power timing became more reliable.

A slew of studies during 2007-09 (CEPT, 2004; IRMA, n.d.; Morris et al., n.d.) on the impact of Jyotigram concluded that there were dramatic improvements in the quality of rural life because of $24 \times 7$ power supply to non-agricultural rural consumers, which led to myriad indirect socioeconomic impacts. None of these, however, explored the agrarian effects, in particular, on the working of water markets. Between 2001 and 2007, however, farm power subsidies in Gujarat declined by Rs.1,100 crore per year (Patel, 2007). The first agrarian assessment effort by International Water Management Institute (IWMI) with the collaboration of 16 college economics teachers found some reduction in the 'waste' of power and water but also major reduction in irrigation area and lost output, livelihoods, and employment. The agrarian stress on farmers varied according to whether they were predominantly buyers or sellers, large or small farmers, and their aquifer conditions. In depleted alluvial aquifers of Mehsana and Patan in north Gujarat, where the water level is deep but groundwater abundant, power rationing seriously restricted the area irrigated per tube well. PostJyotigram, the feeder separation, the use of totas - which earlier enabled tube well owners to run pumps 24 hours daily-became difficult. Things became even more difficult because the government came down heavily on power-theft by establishing 85 'electricity police stations' manned by retired army personnel. ${ }^{3}$ Farmers in hard-rock areas with low yield were less affected because water was a more binding constraint on their pumping than the hours of daily power supply. Small farmers owning tube wells were happy with improved power quality although they had to reduce water selling. Landless sharecroppers and water buyers were adversely affected everywhere because water markets shrank and water prices soared 40-60 percent, driving many of them out of irrigated agriculture.

After implementing Jyotigram, electricity utilities launched a campaign to meter tube wells. All new tube well connections were metered. To encourage farmers to give up flat-tariff connections and adopt metered ones, the government offered a heavily concessional tariff in Gujarat, Gyan Prakash Rai (personal communication in 2017) found the actual price paid to be Rs. $0.77 / \mathrm{kWh}^{4}{ }^{4}$ This led to a rapid increase in metered tube wells, especially in central and south Gujarat. Moreover, such low metered tariff muted the contrast in the selling behavior of metered and flat-tariff water sellers. In their study of Kanjari-Boriavi villages in Anand district, Mishra and Tripathi (2013) found hardly any difference between the behavior of the flat and metered groups of water sellers. Their survey of 100 water buyers in Kanjari-Boriavi also showed little difference between those buying irrigation from flat-tariff and metered tariff tube wells except that the latter charged a 10 percent higher average price. 
A 2010 survey of 60 water sellers and 120 water buyers in north, central, and south Gujarat by Singh and Pillai (2010) concluded that: (i) owners of small-capacity tube wells shifted to metered tariff more than large-capacity, heavy duty tube wells; (ii) tube well owners with strong water-selling businesses hung on to flat tariff; (iii) south and central Gujarat - with a predominance of small tube wells - gradually increased the number of metered tube wells as a proportion of the total while in north Gujarat, flat-tariff remained dominant; (iv) metered tube well owners were less eager water sellers charging high water prices and offering irrigation service of variable quality; (v) average power consumption $/ \mathrm{kW}$ of connected load on flat-tariff connections was 50-80 percent higher compared to metered connections; ${ }^{5}$ (vi) in the Singh and Pillai (2010) sample the hourly price charged by tube well owners for selling irrigation service increased by 50-60 percent in the south Gujarat village of Avidha, 67-80 percent in the central Gujarat village of Adas, and 80-85 percent in the north Gujarat village of Kheralu; (vii) overall, post-Jyotigram, water markets contracted, with a significant (around 40 percent) decline in the average area of buyers' land served by tube wells; ${ }^{6}$ (viii) this effect was countered somewhat by rapid increase in tube well density as a result of a new campaign to issue tube well connections to Scheduled Caste (SC)/Scheduled Tribe (ST) and marginal farmers especially in central and south Gujarat. ${ }^{7}$

\section{Caste dynamics}

An increase in numbers of small tube wells owned by former water-buyers also contributed to reducing the breadth and depth of water markets, especially in water-abundant areas in central and south Gujarat. This growing tube well density improved access to irrigation but seems to have had little impact on monopoly power of sellers and the prices charged by them. There was an irreversible increase in monopoly premium manifested in a much higher W/AC multiple after Jyotigram than before. Mishra and Tripathi (2013) found that the number of pumps within a $500 \mathrm{~m}$ radius increased from 1.6 in 2003 to 4.7 in 2013 , but the average hourly price too increased from Rs.17.75 to Rs.46.8 during the decade, although average pump size had increased only marginally and energy price had stayed put during the decade. In an interesting exercise, Mishra and Tripathi (2013) explored the relationship between pump density and water price and, counter-intuitively, found a positive relationship. Their explanation was that a tube well owner expects buyers to cover his electricity bill through water charges; sellers with more competition have to recover their electricity bills from fewer buyers, who are made to pay higher irrigation charge per horsepower-hour (hph)!

Mishra and Tripathi (2013) survey put into bold relief the caste dynamics of Gujarat's groundwater markets. Patidars always had a lion's share of the 
flat-tariff tube wells, were dominant water sellers, and were generally more clannish. The post-Jyotigram drive to issue metered connections to small and marginal farmers with special accent on SC and ST farmers changed this entrenched social dynamic. They found that new non-Patidar tube well owners were more aggressive water sellers: nearly 80 percent of their pumping hours were sold to buyers compared to 55 percent for Patidar sellers; non-Patidar sellers operated tube wells longer, irrigated larger areas, sold water to farms farther away from tube wells and charged significantly lower prices per hph than Patidar sellers did.

As a demand-management strategy, Jyotigram contributed majorly to a revolutionary strategy for sustainable groundwater governance that the Gujarat government, non-governmental organizations (NGOs) and communities implemented during 2000-15. On the supply side, the government supported agrarian communities to invest massively in decentralized rainwater harvesting and groundwater recharge (RWH\&GWR) in a campaign mode. According to government figures, over half a million RWH\&GWR structures were constructed; thousands of reservoirs were desilted; and surplus water of the Sardar Sarovar Project was used to fill up several thousand village and irrigation tanks - all of which improved groundwater recharge. This would have been of little avail without Jyotigram, which capped overall groundwater draft. Groundwater-level monitoring data of the Central Groundwater Board for 2000, 2008 and 2014 show that despite breakneck agricultural growth rate exceeding 9 percent per year during this period, Gujarat improved its overall groundwater situation with water levels rising during the monsoons in much larger areas during the 2008 and 2014 monsoon seasons than in 2000.

There was much that was perverse about Gujarat's electricity-groundwater nexus before Jyotigram. The most debated was elite capture of farm power subsidies. The analysis offered by Howes and Murgai $(2003)^{8}$ for Karnataka was a forceful statement of this perversion. However, the postJyotigram evidence suggests that the brunt of power subsidy reduction has fallen not on the tube well owners but on marginal farmers and landless laborers. Post-Jyotigram, groundwater irrigation by tube well owners was hardly affected, but that by water buyers seriously shrunk. In response to rationed power supply and the abolition of the use of the tota, tube well owners have made good their loss from the reduced volume of pump irrigation sales with a 30-60 percent increase in pump irrigation price, reduced cost of pump wear and tear, and enhanced bargaining power to make favorable deals with marginal farmers and sharecroppers. It is the latter who have lost out, from the abolition of the tota system and from the shrunken pump irrigation markets. This is evident in reduced opportunities to do irrigated sharecropping, and in marginal farmers being eased out of the pump irrigation economy. The Jyotigram experience shows that controlling electricity subsidies and groundwater overdraft do not come without a significant social cost in the form of growing immiserization of the agrarian poor. 


\section{Permit liberalization and pro-rata tariff in Bengal}

In many ways, West Bengal's energy-groundwater nexus presents a sharp contrast to Gujarat's. Most of West Bengal's districts have abundantly recharged alluvial aquifers with shallow groundwater that is easy to tap. The state has 28 billion cubic meters of annual groundwater availability, enough to provide over 5,000 cubic meters to each of its 5.3 million hectares. The Central Groundwater Authority declared just one of its 340 blocks 'critical' for groundwater overuse. ${ }^{9}$ Yet, throughout the 1960s and 1970s, when tube well irrigation had accelerated the spread of green revolution technology in western states, groundwater development remained slow and halting in West Bengal until the mid-1980s, when diesel-driven shallow tube wells (STWs) took off. West Bengal witnessed a 6 percent annual growth rate in agriculture during the 1980s on the back of rapid expansion in STW-driven irrigation of pre-summer boro rice crop. Like Bangladesh earlier, West Bengal too broke out of its agrarian impasse and morphed from a perennial rice-deficit state to a rice-surplus state, thanks largely to the proliferation of diesel STWs (Rogaly et al., 1999). But come the 1990s, diesel prices began their upward spiral, squeezing the profitability of boro cultivation and slowing down West Bengal's agrarian ascent with growth rates decelerating to 1.2-2.0 percent per year (Sarkar, 2006).

Mukherji et al. (2012) estimated that during 2000-08, the index of cost of labor and fertilizer went up from 100 to 136 and 115 respectively, while that of irrigation costs increased from 100 to 223 at 1999-2000 constant prices, a direct result of farmers' dependence on expensive diesel for pumping groundwater and low rates of electrification of tube wells. Aditi Mukherji, who as an IWMI researcher in Gujarat had earlier studied the pros and cons of the electricity-groundwater nexus in that state, noted the yeomen service that electric submersible owners in West Bengal were performing for their water buyers. West Bengal Electricity Board charged tube well owners high flat tariffs until then, which produced a buyers' water market. In order to generate cash to cover their high flat tariff bills, electric submersible owners competed fiercely to sell more and in the process offered farmers high quality irrigation services at a low price compared to diesel STW owners. Mukherji argued that electric WEMs could save West Bengal farmers from the trauma of soaring diesel prices. However, the state had less than 100,000 electric STWs; ${ }^{10}$ and their numbers were growing far too slowly due to a restrictive system of groundwater permits, which an oppressive bureaucracy had turned into an instrument of rent-seeking from farmers. From a high of over 10,000 new connections for tube wells issued per year in the late 1980 s, the rate had fallen to less than 2,000 per year during the mid-1990s and to less than 500 per year thereafter. Rampant rent-seeking and arbitrary rejection of applications for new connections was common. Boro rice crop, which lay at the heart of West Bengal's agrarian 


\section{4}

Tushaar Shah and Sujata Das Chowdhury

growth during the 1980s, suffered rapid declines in the first decade of the new millennium because of this tube well permit system.

Thanks largely to Mukherji's research and advocacy, West Bengal's Water Resources Investigation and Development Department (WRI\&DD), via a memo dated 9 November 2011, abolished the system of tube well permits. ${ }^{11}$ Moreover, the West Bengal State Electricity Distribution Company Limited, which hitherto extracted the full cost of wires, poles and transformers based on the distance from the network, fixed a flat connection fee ranging from Rs.1,000 to Rs.30,000 per connection depending on the connected load and distance. This drastically reduced the set-up cost of an electric tube well for farmers (Mukherji et al., 2012).

Mukherji et al. (2012) expected this new policy to unleash an agrarian turnaround in West Bengal. They projected, under some conservative assumptions, that the net irrigated area of the state would increase from 2.98 million ha to 4.83 million ha in a short span of three to five years, resulting in a 4.62 MT increase in boro rice production and additional farm income of Rs.460 crore. The expectation was that the new policy would unshackle groundwater irrigation, expand electric tube well irrigation, restrain monopolistic behavior of water sellers and usher in competitive groundwater markets.

Where competition in local water markets was concerned, however, the impact of liberalization of tube well permits was likely more than offset by an earlier policy of introducing tamper-proof metering electric tube wells and charging farmers based on actual consumption of power (Mukherji et al., 2009). West Bengal also introduced a time-of-day differential tariff system with three time zones and peak power between $5 \mathrm{pm}$ and $11 \mathrm{pm}$, nearly five times costlier compared to off-peak night power. Metering replaced the system of flat tariff and had profound impact on the dynamics of groundwater markets. Shah (1993) had argued that under a flat tariffinduced buyers' water market, tube well owners tend to absorb increases in flat tariff and pass on only part of it to buyers for the fear of losing their market share. In support of this hypothesis, Mukherji et al. (2009) found, based on panel data from three surveys in 2004, 2008 and 2008 that

from 1995 to 2004, the flat tariff had increased from Rs.1,100 per year to Rs.6,850 per year for submersible pumps (a six-fold increase), while water rates only increased from Rs.625 per acre to Rs.1,500 per acre (just over two times) for summer boro paddy.

Under the flat-tariff regime, buyers used their strong bargaining power to secure lower price, deferred payment facilities, etc., that had profound redistributive effects since the water buyers are small and marginal farmers belonging to lower castes. To remain viable in tube well irrigation, tube well owners were constantly under pressure to propitiate water buyers. Little surprise that they unionized to demand metered tariff for irrigation tube wells, 
and successfully lobbied with the government for installation of meters (Mukherji et al., 2009).

The impacts of metering were evident within a year. In a 2008 survey, soon after metering began, Mukherji et al. (2009) found that two-thirds of the pump owners preferred metered tariff, while only a quarter of the water buyers did. Water rates went up by 30-50 percent even when Mukherji et al. (2009) found that over two-thirds of water sellers would have to now pay less for electricity and not more, for previous level of pump operation. Unlike under high flat tariff earlier, pump owners were no longer under pressure to sell and, overnight, a buyers' water market turned into a sellers' market. In four of 17 survey villages Mukherji covered in her survey, the area under boro paddy declined in the immediate aftermath of metering. Rising monopoly power of pump owners also began to be manifested in their growing penchant to lease in buyers' land for boro cultivation than selling water to them. Mukherji et al. (2009) found evidence of this in 10 out of their 17 survey villages.

In a 2014 survey of five villages in Birbhum district, Chowdhury (2015) found that change in groundwater law had increased the number of water sellers in her survey villages (Table 11.1) from 47 before 2011 to 134, signifying that permit liberalization was producing the intended increase in WEM density in West Bengal agriculture. For a decade before 2011, boro cultivation had stagnated or even declined, but by 2014, it had bounced back, with nearly every acre brought under plough in boro season. During the 2011-14 period, the amon (June-July) rice area increased marginally, but boro rice area nearly doubled (Figure 11.1). Chowdhury found farmers happy with abolition of tube well permits and low set-up cost of electric WEM, but were unhappy with their soaring electricity bills. There was, however, a hardening of monopoly power of WEM owners who formed a cartel to fix the water rates every year. Pump owners increasingly preferred leasing in land from water buyers only for boro rice cultivation at a fixed rental of 1.2 quintals of paddy or a cash rental of Rs.2,000 per bigha. According to Chowdhury's calculations, a pump owner can earn only Rs.1,500 by selling irrigation to a bigha of boro paddy but can make a net surplus of Rs.4,225 to Rs.10,425 by leasing in a bigha for boro paddy cultivation after paying all costs as well as the lease rental of Rs.2,000 per bigha (or 1.2 quintals of paddy). She found interlocking of water transactions. Many pump owners committed to providing amon irrigation only on the condition that the buyer leases out all or a portion of his land to him for boro cultivation. Refusing boro irrigation was another strategy to compel small farmers to lease out their land.

West Bengal always had booming land tenancy markets. These are changing under the impact of the metering and permit liberalization 'policy dyad'. Three tenancy contracts dominate: (i) landowner and tenant share all costs and output 50:50; (ii) landowner bears all cash costs and tenant claims one-third of the produce for her labour; (iii) tenant bears all 
Table 11.1 Impact of Liberalization of Tubewell Permits

\begin{tabular}{ll}
\hline During 2001-11 & After 2011 \\
\hline The cost of a connection: Rs.21,000 & $\begin{array}{l}\text { The cost of a connection: Rs.8,100 for } 4 \text { poles } \\
\text { away }\end{array}$ \\
$\begin{array}{l}\text { Waiting time: } 3-4 \text { years } \\
\begin{array}{l}\text { Transaction cost: } 15 \text { visits to district } \\
\text { town to get SWID certificate }\end{array}\end{array}$ & $\begin{array}{l}\text { No transaction costs to get SWID certificate } \\
\text { Bribe to SWID staff: Rs.20,000 }\end{array}$ \\
$\begin{array}{l}\text { Commission to contractors: Rs.5,000-10,000 } \\
\text { ahead of boro season's peak irrigation demand }\end{array}$ \\
\hline
\end{tabular}

cultivation costs and pays to the landowner a fixed rental of 7.2 quintal of paddy for kharif season and a lower 3.6 quintal per acre in boro season, presumably because of the latter's high input and irrigation cost. Labor scarcity drives growth in type (ii) tenancy; and submersible owners' growing monopoly power under metered tariff is driving type (iii) tenancy, both types dominating boro tenancy. Figure 11.2 shows that the proportion of pump owners who expanded their boro cultivation via tenancy type (iii) rapidly expanded after 2011. Type (ii) tenancy too has grown but not quite as much as type (iii). Figure 10.3 suggests that in at least five villages that Chowdhury surveyed in 2014, the new 'policy dyad' is resulting in a rapidly growing boro rice economy that is getting captured by pump owners at the expense of the marginal farmer water buyers. To be accurate, it must be noted that smallholders owning submersibles are much more aggressive in leasing-in boro land to leverage abundant family labor and captive irrigation source. In doing so, they use negative as well as positive incentives. ${ }^{12}$ Figure 11.3 shows that pump owners have no interest in leasing in land for amon, but only in the irrigation-intensive boro season; the average leased-in boro land operated by water buyers too has increased after 2011; but it has nearly quadrupled for the sample of pump owners, from 0.6 acres to 2.2 acres.

More important than the shift from flat tariff to metering in 2007 is the rapid increase in farm power tariff in West Bengal. As Figure 11.4 shows, average tariff, computed with equal weightage given to three time zones of the day, has increased nearly threefold from Rs.2.31 per kWh in 2009 to Rs.6.51 per $\mathrm{kWh}$ in 2016. Because farmers can reduce their electricity bills by avoiding pumping during peak-load hours, the actual price would be somewhat lower than Rs.6.51 per kWh. During July 2016 and April 2017, the average actual price paid by a sample of 12 tube well owners in Manoharpur village near Shantiniketan was Rs.5.18 per kWh (Rs.4.09 per kWh was the lowest for a tube well owner who pumped most during off-peak hours and Rs.5.55 per kWh, the highest for a farmer who pumped during all time zones). ${ }^{13}$ This is arguably the highest electricity price actually paid 


\section{- \% of pump owners leasing in land during amon \\ $\because \%$ of pump owners leasing in land during boro \\ : \% of water buyers leasing in land during amon \\ $=\%$ of water buyers leasing in land during rabi}

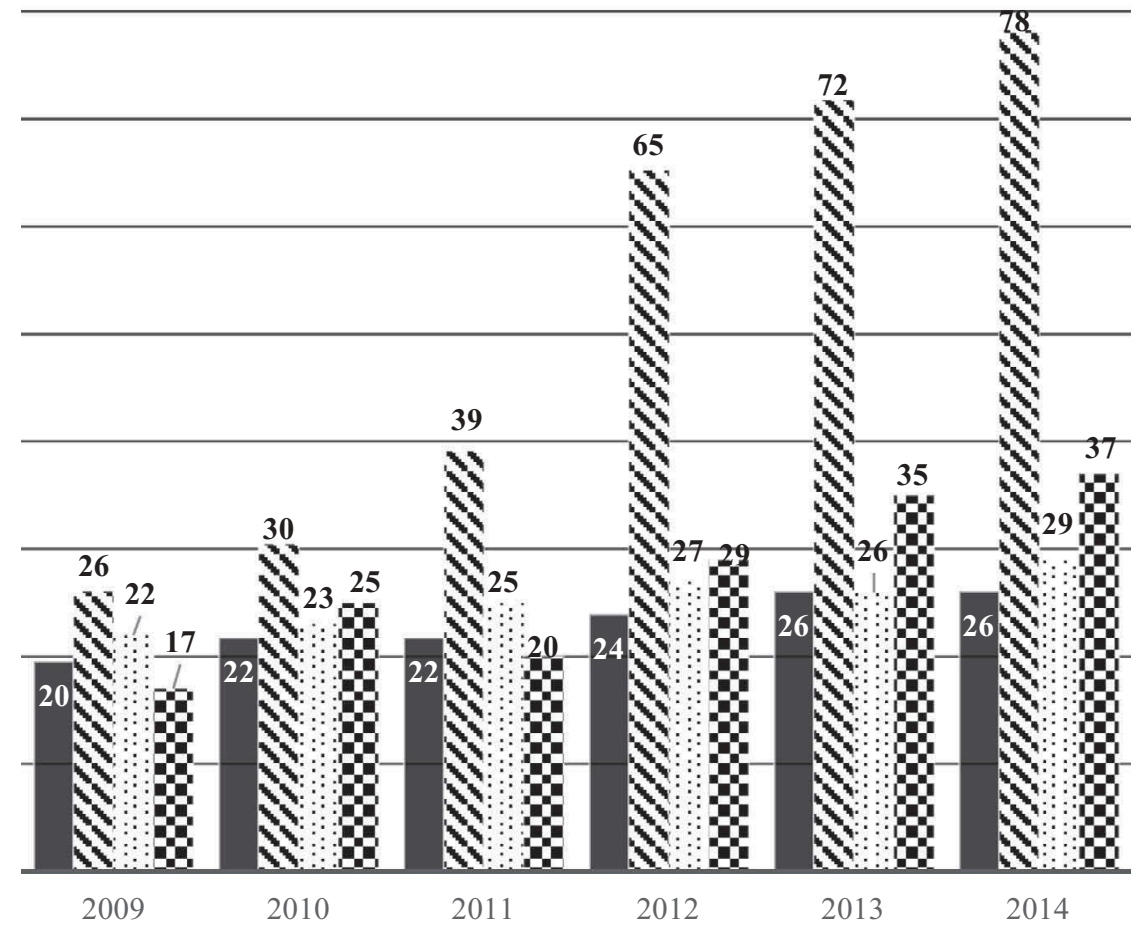

Figure 11.2 Rising Profile of Pump Owners in Boro Season Land Lease Market

by farmers anywhere in India. Moreover, unlike in states like Maharashtra and Rajasthan, where electricity distribution companies (DISCOMs) fail to collect even subsidized farm power bills from farmers, West Bengal imposes and collects heavy penalty for delayed payments. While farmers cannot avoid paying up their electricity bills, we were told that power theft by farmers is growing and emerging as a potentially major vigilance issue. While 


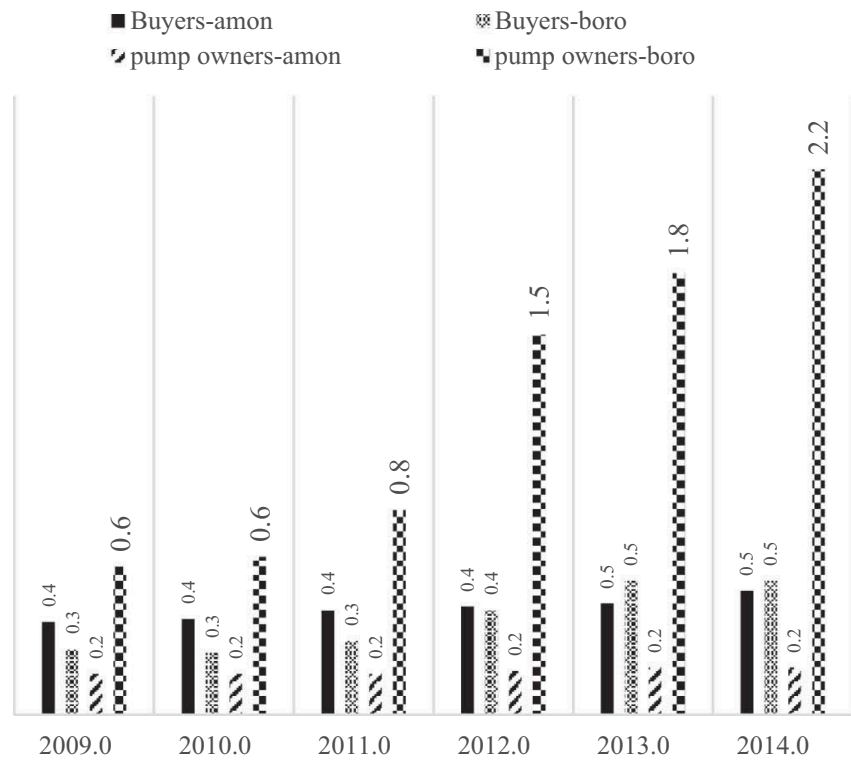

Figure 11.3 Increase in Average leased in Land Operated by Water Buyers and Pump Owners

farmers were reluctant to talk about this in depth, many indicated that with rapid increase in pro rata tariff, illegal 'hooking' has become highly profitable. Chowdhury's survey data show that pump owners have not raised water prices in proportion to the rise in electricity prices (Figure 11.5). During 2009 to 2014, boro irrigation price has risen by less than twice, reducing the W/AC multiple by a significant extent. Figure 11.6 compares the indices of average electricity price, amon and boro irrigation prices. This shows that boro irrigation rates have risen more slowly compared to average electricity tariff.

What explains this? After all, they can exercise their monopoly power by putting up irrigation price pari passu with electricity tariff. There may be several reasons at play. One is that the cartel will be under pressure if one or a few sellers drastically raise prices but others do not follow. ${ }^{14}$ According to Chowdhury, water sellers are united in defending an agreed price and will seldom encroach upon the customer of another seller in her sample villages. Another is that many water sellers are also water buyers. Third, a kind of moral economy comes into play; profitability of paddy cultivation is under constant stress from rising input prices; moreover, the last thing pump owners want is farmers deserting boro paddy farming. Finally, pump owners can reap much larger profits by leasing in land under type (iii) contract as 'residual claimants' than by selling water at higher prices. Selling 


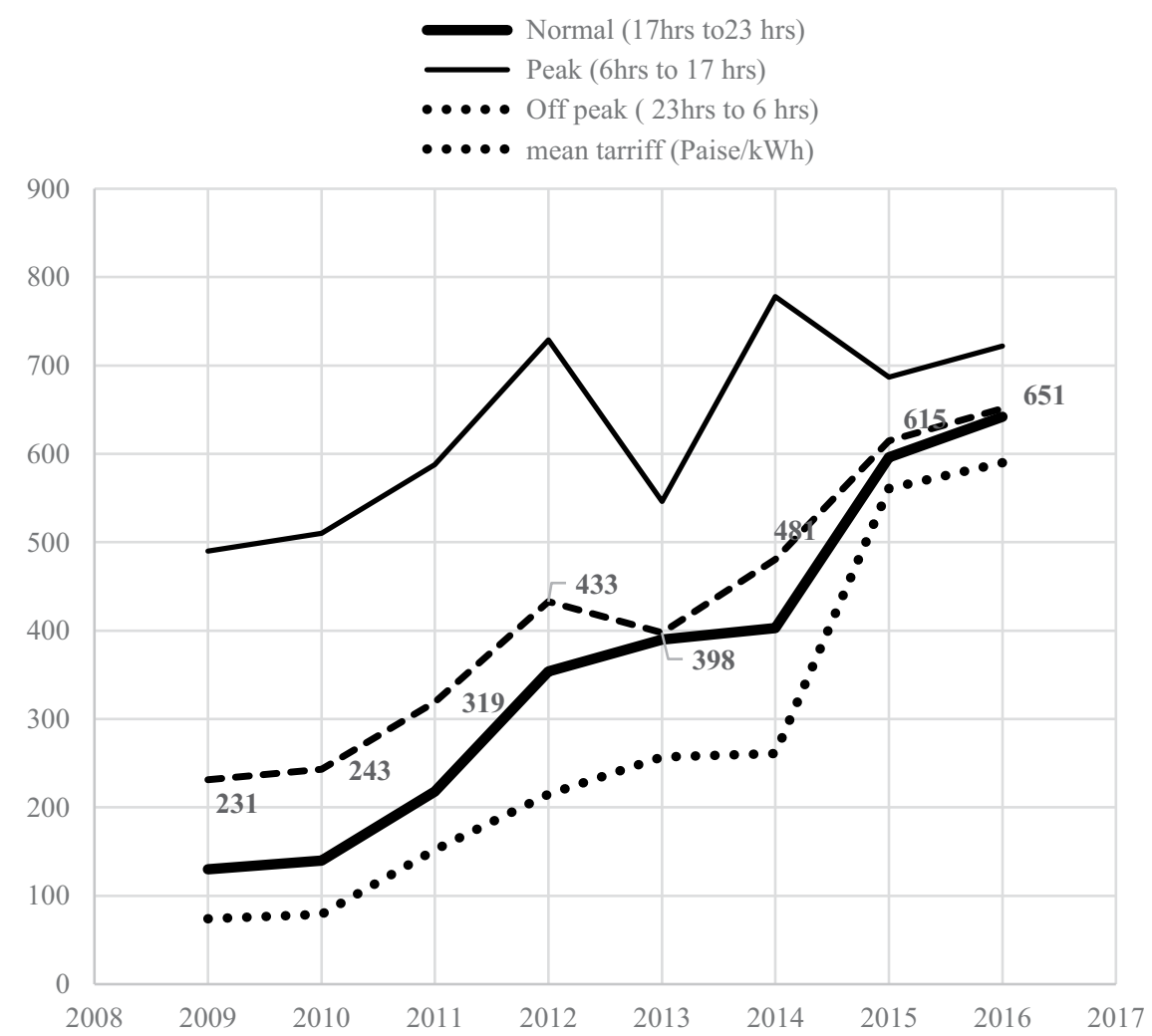

Figure 11.4 Pattern of Rise in ToD Power Tariff for farmers in West Bengal

irrigation to one acre of paddy fetches them a net income of Rs.1,200-1,500 after electricity costs are paid; but irrigating a leased-in acre of boro paddy earns them three to six times as much net profit since the going fixed rental is only $360 \mathrm{~kg}$ per acre of paddy.

In a recent case study of groundwater-abundant Kumarpur village in North 24 Paraganas district, Banerjee (2016) found that post-2012, electric submersible WEMs increased from 20 to 28 , and as a result, the earlier trend of boro rice area to decline was reversed leading to a boom in boro rice and year-round vegetable cultivation through water markets. However, he found that the economics of boro rice cultivation with purchased irrigation are turning awry because the water price has doubled from Rs.1,000-2,000/bigha of boro rice irrigation. Like Chowdhury (2015) and Mukherji et al. (2010) earlier, Banerjee (2016) also found that submersible owners were more aggressive in leasing in land for boro paddy cultivation at a fixed rental of $180 \mathrm{~kg}$ paddy per bigha. 


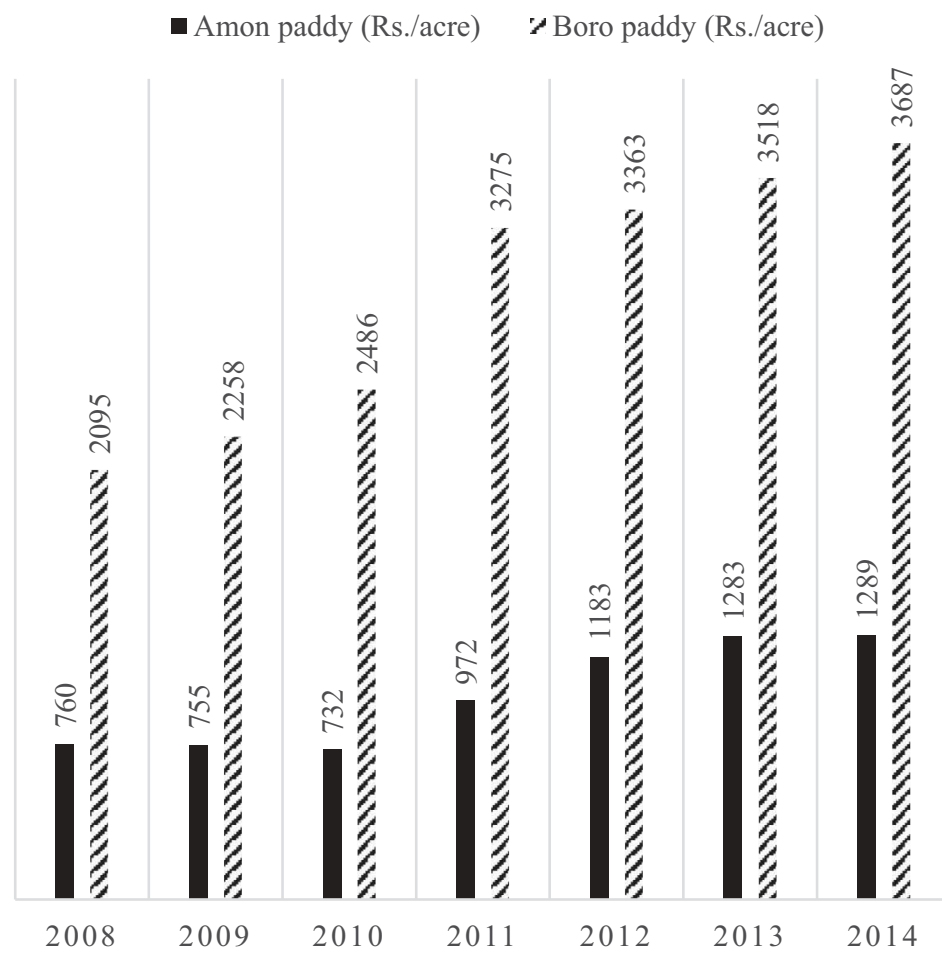

Figure 11.5 Average price (Rs./acre) Charged by Submergible Pump Owners for Paddy Irrigation

Selling water seems to compensate more than his/her total cost of electricity and helps earning a good sum of profit. Hence some farmers are now installing more than one submersible pump. We met one substantial farmer who had already installed two submersibles and applied for the third. So water selling seems to have emerged as a good commercial activity in the post-liberalization period.

\section{Conclusions}

Over the past 25 years, groundwater markets in Gujarat and West Bengal have been transformed because of significant changes in electricity supply and pricing policies applicable to farmers. One key impact variable affected which mattered the most to resource-poor water buyers was the monopoly power of water sellers captured by the W/AC ratio. The policy of tamperproof rationing of low-cost power under the Jyotigram Yojana in Gujarat resulted in increasing the monopoly power of sellers. The vigorous campaign 


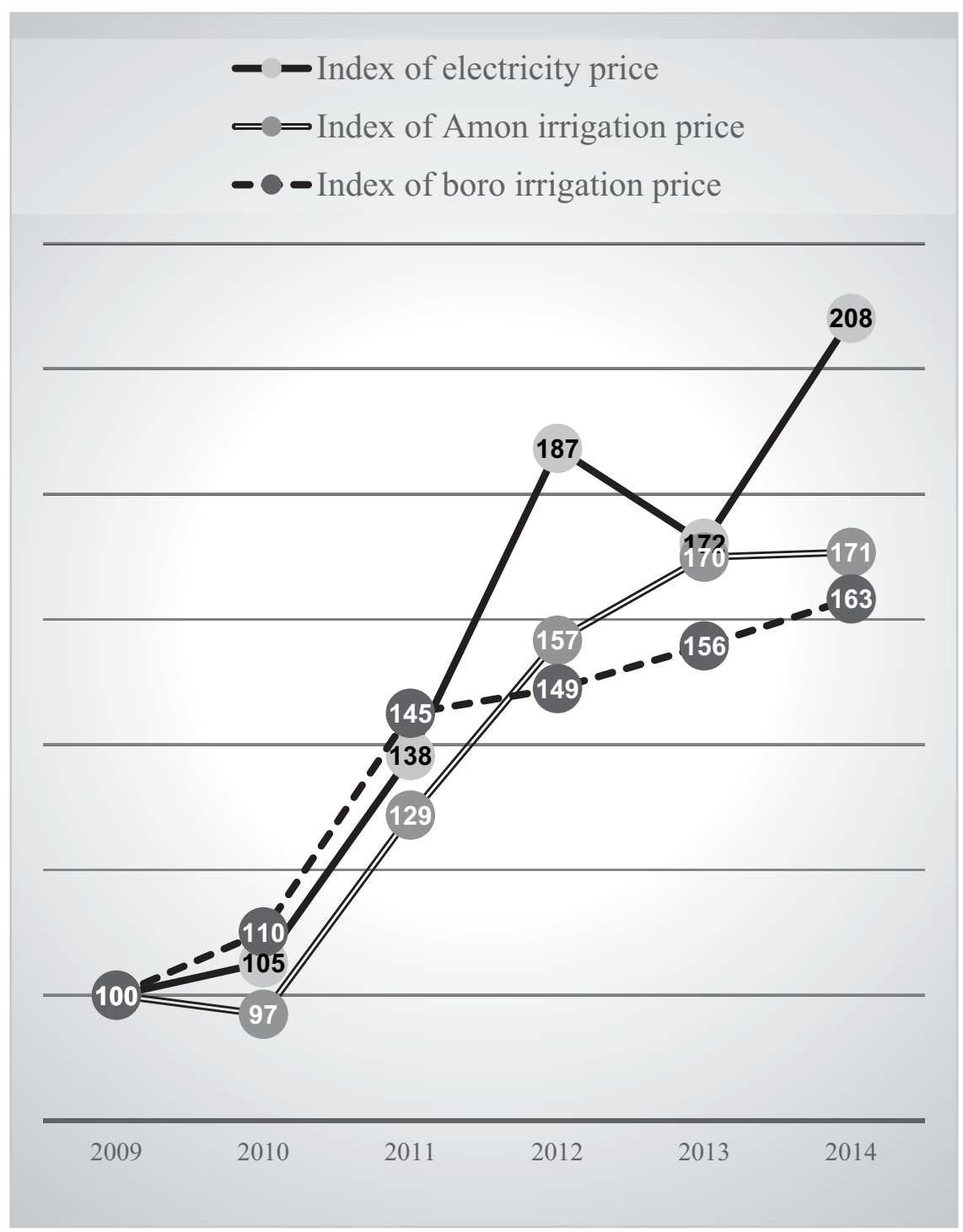

Figure 11.6 Indices of Mean Electricity Price and Irrigation Service Price Levied by Submergible Pump Owners

to turn flat-tariff connections to metered connections further increased the W/AC ratio in spite of the subsidized metered tariff. Early assessments highlighted the growing stress on water buyers. The Government of Gujarat intervened subsequently by issuing 450,000 new metered connections targeted to small and marginal farmers belonging to SCs and STs. These 
farmers seem to have emerged as vigorous water sellers in a traditionally Patidar dominated groundwater economy.

Most of these new connections have been issued in groundwater-safe tribal areas of south and central Gujarat. The increased WEM density combined with the comfortable groundwater resource situation here has countered the impact of power-rationing as well as metering on W/AC ratio. Water buyers seem to be at no major disadvantage here. They constantly search for bargains and better terms, and most sellers accept payment at the end of the season. In old pockets of hyperactive groundwater markets, however, water buyers are suffering stronger monopoly power of sellers. In groundwater-stressed pockets of north Gujarat - such as in districts of Patan, Mehsana, Banaskantha-things have turned seriously against resource-poor water buyers. Farmers who have old flat-tariff connections have steadfastly refused to accept metering, and there is little demand for new metered connections. Power rationing has made monopolistic water markets worse, with buyers increasingly being obliged to lease out their land to water sellers. Water sellers demand one-third crop share for supplying water, and deal with only those buyers known for their diligent farming (Singh and Pillai, 2010).

In West Bengal, the government liberalized a repressive regime of tube well permits at the urgings of Aditi Mukherji, a social researcher who hoped doing this would increase the density of electric submersibles and render the groundwater market more competitive, limiting the monopoly power of sellers. The government adopted the recommendations, scrapped the repressive permit policy, and actually reduced in large part the cost of buying new electric STWs for farmers. This seems to have rapidly increased the density of electric submersibles in rural West Bengal, which in turn expanded boro paddy cultivation rapidly. This policy would likely have had a massive impact of reducing W/AC in West Bengal's market under the earlier regime of high flat tariff for electricity. However, West Bengal became the first state to vigorously meter its electric tube wells and begin levying a consumption-based time-of-day power tariff, which has nearly tripled over the past decade. Metering of tube wells has raised the W/AC ratio to the disadvantage of water buyers, thereby largely nullifying the potential equity impact of permit liberalization.

In a Bangladesh village, Fujita (2004) had found that increasing WEM density by itself reduced the monopoly power of water sellers and W/AC ratio. He found that water sellers claimed two-thirds share in the net irrigation surplus created through the water market in 1991-92, but by 1999, this share had fallen to 13 percent, thanks to increased STW density and declining average command area. According to Fujita (2004):

The cost of irrigation did not change in nominal terms, which means that in real terms it declined substantially if inflation is taken into account. In addition, the high rate of profit accrued to tube well owners in 1992 totally disappeared, which contributed to a substantial decline of real water price faced by water buyers. Second, while the share to 
water decreased sharply, the share to land rose to a very high level. It increased from 22 percent to 49 percent, almost equal to that in the traditional crop-sharing system.

Mukherji et al. (2009: 5539) too surmised that increased density of electric submersibles would counter the natural oligopoly of water markets in suggesting that 'the Government of West Bengal needs to take steps to accelerate the pace of electrification of tube wells in the state. This will enhance competition in the water markets and in response, water prices might decline'.

Our patchy indicative evidence from West Bengal suggests a different picture. Here, tube well density has increased, total area served by water market has grown, and average area commanded per submersible is under threat of shrinking. Yet, the real price of irrigation has significantly increased, if the cost to buyer of leasing out their land to WEM owners for boro cultivation is factored in. The share of water in net irrigation surplus too has stayed put, if not actually increased. If the trend of water sellers leasing in more land for boro cultivation at a paltry fixed rental is any guide, the share of land has not increased at all. Ownership of electric submersibles is increasingly becoming a more important wealth-creator in West Bengal agriculture than ownership of land. Permit liberalization combined with metered electricity has had a liberating impact on the water seller but it may have turned West Bengal's electric submersible owners from 'privately-operated public utility' earlier (under high flat tariff) into a 'pumping for-profit' machine that is capturing a growing share of the state's boro rice economy.

In our view, West Bengal can maximize the equity benefits of tube well liberalization by tweaking its electricity pricing policy. West Bengal already has in place a flat-cum-metered tariff of the kind that many electricity utilities deployed during the early 1960s. Under this regime, a monthly fixed charge of Rs.205 is levied regardless of actual power consumption; in addition, a pro rata charge of Rs.3.78 per $\mathrm{kWh}$ is levied on metered consumption. All evidence of the working of informal groundwater markets in West Bengal, Gujarat and elsewhere in India suggests that collecting a larger proportion of the annual cost to serve a tube well connection through fixed charge rather than consumption-linked charge will: (i) incentivize tube well owners to compete harder in the water market to generate enough revenue to cover fixed costs; (ii) offer water buyers better irrigation service at lower prices; and (iii) reduce the incentive to pilfer power. In keeping with this evidence, the electric submersible owner should be required to pay a fixed charge, of say Rs.1,000 per hp. per month during the four months of boro season and Rs.500 per hp. per month during other months. In addition, throughout the year, he/she should be charged a consumption-linked rate of Rs.1.5 to Rs.2.0 per kWh based on meter readings. Such an electricity pricing regime will restore submersible owners' role as 'privately operated public utilities', rein in unfettered monopoly power of water sellers and turn the water market again into a buyers' market to the benefit of the poor. For the DISCOMs, the major benefit would be 


\section{4}

reduced vigilance cost as incentive to pilfer power by illegal 'hooking' gets muted. Notably, such a regime would be less repugnant for submersible owners than the high flat tariff regime (and zero pro rata charge) that prevailed before metering. Moreover, it would also be revenue-neutral for the electricity company if it periodically adjusts the fixed component of the tariff to cover the actual average cost to serve farm power. In our view, a larger fixed component is particularly justified now when the utility covers the full cost of connecting a new tube well, which it can recover only if the average submersible is operated at full capacity.

The issues raised in this chapter require more systematic and detailed studies. While our data is patchy, it seems clear from the experience of Gujarat as well as West Bengal, that the reduction of electricity subsidies - either through power rationing as in Gujarat or metered power pricing as in West Bengal - have hit the poor water buyers harder than water sellers. This is seen in water-scarce Gujarat as well as in water-abundant West Bengal. The Howes and Murgai (2003) assertion that power subsidies benefit only large tube well owners appears ill-founded. There are indications that WEM owners were making hay with electricity subsidies earlier and are now making hay without. The point is metered tariff has transformed resourcepoor water buyers from co-gainers of irrigation surplus creation into sole losers. The point of our analysis is that there exists a smart farm power pricing solution that can deliver a larger irrigation pie and its more equitable division between owners of tube wells and buyers of water. Finding and implementing such a solution can make a huge difference to millions of marginal farmers and tenants who are completely dependent on private water markets for their food and livelihoods security.

\section{Notes}

1 This is a revised version of a paper presented at the eighth INFDAS International Conference, 'Toward Sustainable Development of India and South Asia' at Kyoto University, Japan, 17-18 December, 2016. The authors gratefully acknowledge comments by an anonymous referee.

2 Motors running irrigation pumps have a pf of 0.7-0.8, which the use of a capacitor can raise to 1 . A $100 \mathrm{kVA}$ transformer can be connected to 26 motors of $5 \mathrm{hp}$ with capacitors instead of 18 without getting overloaded. Capacitors improve the voltage and reduce the load on the transformer and in general curtail power loss in distribution. See, PRAYAS (2004) Know Your Power: A Citizens' Primer on the Electricity Sector, Prayas Energy Group, Pune. http://prayaspune.org/peg/publications/item/ 151-a-citizens-primer-on-the-electricity-sector-second-edition.html.

3 At one stage, court cases were filed against over 100,000 farmers and others caught stealing power (Dasgupta, 2016): 'In 2007, during the Gujarat assembly election, Modi had come under intense party pressure to waive the dues and the prosecution of more than one lakh farmers caught pilfering electricity through unauthorised connections'.

4 Metered tube well owners used 7.28 lakh kWh and paid Rs.5.78 lakh (average price Rs.79/kWh); flat tube well owners used 1.47 lakh $\mathrm{kWh}$ and paid Rs.97,555 (average price Rs.0.66/kWh). 
5 In Mehsana, Sabarmati, Palanpur and Himmatnagar circles, for which Singh and Pillai (2010) could get data from the electricity utility, they found only 70,000 metered connections against 155,600 flat tariff connections; the average size of the former was $23 \mathrm{hp}$. versus $17 \mathrm{hp}$. for the latter; average power consumption $/ \mathrm{kW}$ for flat tariff tube wells was $1,837 \mathrm{kWh}$ per year while that for the metered connections was $1,164 \mathrm{kWh}$ per year.

6 In Singh and Pillai (2010)'s survey, the average bigha of buyers' land irrigated in north Gujarat declined from 34 to 20 , in central Gujarat from 32 to 18 , and in south Gujarat from 35 to 21.

7 In their study of Kanjari-Boriavi villages in Anand district of central Gujarat, Mishra and Tripathi (2013) found that before 2000, tube wells were mostly owned by Patidar farmers who also controlled the water market; since 2000, non-Patidar farmers emerged as new tube well owners playing a significant role in the local water market.

8 See Howes and Murgai (2003). Also see Narendranath et al. (2005).

9 http://cgwb.gov.in/gw_profi les/st_westbengal.htm, viewed on 8 January, 2017.

10 According to Mukherji et al. (2009), in 2003, electric WEMs were only 8.5 percent of total WEMs in West Bengal while they were 82.5 percent in Tamil Nadu and 93.5 percent in Andhra Pradesh.

11 It exempted farmers located in 301 or so 'safe' groundwater blocks and owning pumps of less than 5 horsepower (hp.) and tube wells with discharge less than $30 \mathrm{~m}^{3}$ / hour from having to get permits for groundwater use from the State Water Investigation Directorate (SWID) under the West Bengal Groundwater Resources (Management, Control and Regulation) Act 2005. This effectively put all farmers except those located in 37 semi-critical blocks outside the purview of the act.

12 According to Chowdhury, submersible owners fiercely compete with each other to get more leased in land, often offering advance payments of Rs.2,000-2,500/ per bigha to land owners.

13 Manisha Shah, personal communication (4 June, 2017).

14 In villages surveyed by Chowdhury, some submersible owners had to disconnect their WEMs for want of enough land to irrigate.

\section{References}

Banerjee, P. S. (2016). "A Case Study on Liberalization of Electric Pumps in Irrigation Kumarpur Village, North 24 Parganas District, West Bengal," unpublished report for IWMI-Tata Program.

CEPT (2004). Jyotigram Yojana 'Powering' Rural Gujarat-A Rapid Impact Assessment Study, Districts: Mehsana and Patan, Ahmedabad: Centre for Environmental Planning and Technology (CEPT).

Chowdhury, S. D. (2015). "Report on Impact of Liberalized Electrification," unpublished report for IWMI-Tata Water Policy Program.

Dasgupta, S. (2016). "The Chattering Classes Just Don't Get This Surgical Strike," Times of India, Ahmedabad, 13 November, 16, http://blogs.timesofindia.indiatimes. com/right-andwrong/the-chattering-classes-just-dont-getthis-surgical-strike/.

Fujita, K. (2004). "Transformation of Groundwater Market in Bengal: Implications to Efficiency and Income Distribution," paper presented at The 18th European Conference on Modern South Asian Studies, Lund, Sweden, 6-9 July, s3.amazonaws.com /zanran_storage/www.sasnet.lu.se/ContentPages/15778866.pdf.

Howes, S. and R. Murgai (2003). "Incidence of Agricultural Power Subsidies: An Estimate," Economic \& Political Weekly, vol. 38(16), pp. 1533-35. 
IRMA (n.d.). "Impact Assessment of Jyotigram Yojana in Gujarat," Report of a Study for the Confederation of Indian Industry by Institute of Rural Management, Anand.

Mandal, M. A. S. (2000). "Dynamics of Irrigation Water Markets in Bangladesh," Changing Rural Economy of Bangladesh, M. A. S. Mandal (ed.), Dhaka, Bangladesh: Economic Association, pp. 118-28.

Mishra, M. and P. Tripathi (2013). "Agricultural Pumping Behaviour of Farmers after Jyotigram: Study of a Village in Central Gujarat, Anand," IRMA, unpublished student report.

Morris, S., A. Pandey, S. Aggarwal, and M. S. Sriram (n.d.). Impact Assessment of the Jyotigram Scheme of Government of Gujarat, Ahmedabad: Indian Institute of Management.

Mukherji, A., B. Das, N. Majumdar, N. C. Nayak, R. R. Sethi, B. R. Sharma, and P. S. Banerjee (2009). "Metering of Agricultural Power Supply in West Bengal, India: Who Gains and Who Loses?" Energy Policy, vol. 37(12), pp. 5530-39.

Mukherji, A., T. Shah, and P. S. Banerjee (2012). "Kick-starting a Second Green Revolution in Bengal," Economic \& Political Weekly, vol. 47(18), pp. 27-30.

Mukherji, A., T. Shah, and S. Verma (2010). "Electricity Reforms and Their Impact on Ground Water Use in States of Gujarat, West Bengal and Uttarakhand, India," On the Water Front: Selections from the 2009 World Water Week in Stockholm, J. Lundqvist (ed.), Stockholm: Stockholm International Water Institute (SIWI), pp. 100-07.

Narendranath, G., U. Shankari, and K. R. Reddy (2005). "To Free or Not to Free Power: Understanding the Context of Free Power to Agriculture," Economic \& Political Weekly, vol. 40(53), pp. 5561-70.

Pant, N. (1991). Development of Groundwater Markets in Eastern Uttar Pradesh: IndoDutch Uttar Pradesh Tubewell Project, Lucknow, India: Centre for Development Studies.

Patel, D. (2007). "Paanch Varsh ma Subsidy ma 1100 Karod No Ghatado," Divya Bhaskar, Ahmedabad edition, 3 March.

PRAYAS (2004). Know Your Power: A Citizens' Primer on the Electricity Sector, Pune: Prayas Energy Group, http://prayaspune.org/peg/publications/item/151-a-citi zens-primer-on-the-electricity-sector-second-edition.html.

Rogaly, B., B. Harris-White, and S. Bose (1999). Sonar Bangla? Agricultural Growth and Agrarian Stagnation in West Bengal and Bangladesh, New Delhi: Sage Publications.

Sarkar, A. (2006). "Political Economy of West Bengal: A Puzzle and A Hypothesis," Economic \& Political Weekly, vol. 41(4), pp. 341-48.

Shah, T. (1987). "Social and Economic Dimensions of Groundwater Development in India," Jal Vigvan Sameeksha, vol. 2(1), pp. 89-103.

(1993). Groundwater Markets and Irrigation Development: Political Economy and Practical Policy, Bombay: Oxford University Press.

Shah, T., S. Bhatt, R. K. Shah, and J. Talati (2008). "Groundwater Governance through Electricity Supply Management: Assessing an Innovative Intervention in Gujarat, Western India,” Agricultural Water Management, vol. 95(11), pp. 1233-42.

Shah, T., C. Scott, A. Kishore, and A. Sharma (2004). Energy-Irrigation Nexus in South Asia: Improving Groundwater Conservation and Power Sector Viability, Colombo, Sri Lanka: International Water Management Institute Research Report \#70.

Shah, T., M. ul Hassan, M. Z. Khattak, and P. S. Banerjee (2009). "Is Irrigation Water Free? A Reality Check in the Indo-Gangetic Basin," World Development, vol. 37(2), pp. $422-34$. 
Shah, T. and S. Verma (2008). "Co-management of Electricity and Groundwater: An Assessment of Gujarat's Jyotirgram Scheme," Economic \& Political Weekly, vol. 43 (7), pp. 59-66.

Singh, S. and H. P. Pillai (2010). Electricity Policy Reforms and Its Impact on Groundwater Use in Gujarat, Anand: IRMA, unpublished student report. 


\section{Index}

Note: page numbers in italics relate to the figures on this page; page numbers in bold relate to the tables on this page; 'n' to use to show the relevant note of the page.

abadkari 79 ; raiyat 76,78

adaptation 3, 38-39, 48-50, 59, 60, 62n8 agrarian society $4,39,51,66,68,76$, $78-79,84$

agricultural: commercialization 56,60 ; electricity $9,74,141,157,184,201,205$, 207, 209, 217, 219, 221; feeder 229; laborer 45, 50, 57, 59-60; policy 175 , $177,180,218$; prices $3,25,66,83,218$; productivity $160-61$; risks $38-39,59$

ahar 6-7, 13n5; cross-section 113, 124; density 123; geographical distribution 113,121 ; maintenance 109, 119-20, 126; rainfed 6, 109, 113, 116, 118-19, 125-26; water storage capacity 124 ahar-pyne system 6, 109-10, 113, $116,122-26$

alluvial: deposit 68; plain 10, 12, 124, $126,147-48$; soils $202,219,221$ aquifer $10,12,90-91,93,95,97, \mathbf{1 0 3}$, $119,126,132,147,149,202,230,233$ arsenic contamination 148

Bangladesh 10, 13n4, 14n12, 141, 147-54, 155n1, 155n4, 156n10, 156n16, 157n25, 157n30, 233, 242

Barnard Records 19-20

Bengal 2-4, 10, 13n2, 14n12, 50, 66, 67, 68-70, 74, 76-77, 79-85, 210; eastern 13, 80, 85n2; see also Bangladesh; West Bengal

Bihar 2, 6, 13n5, 81, 109, 110, 113, 122, $138,148,150,152,154,199$

biodiversity 168,174
Board of Revenue 24, 62

boat-building industry 74

bore well 1, 216-18

boring pump 109, 118-19

Brahmin 26

Calcutta rice market 81

canal 5, 35, 80, 90, 104-05, 109, 110, 113, $116,121-22,125,163,170-71,202-03$, 208, 226, 228

caste $3,22, \mathbf{2 3}, 36 \mathrm{n} 5,38-40, \mathbf{4 1}-\mathbf{4 2}, 43$, $45,48-51,53-57,59-60,63 \mathrm{n} 25,85 \mathrm{n} 19$, 213, 231, 234; dominant 53-56, 59, $62 \mathrm{n} 17$

Census 26, 28, 31-32, 33, 34, 40, 66, 67, 69, 73; Agricultural 138, 139-40; Minor Irrigation $155 \mathrm{n} 9$

cereal production $7,8,176,184-85,188$, 189, 195-97, 199

Chingleput 19-20, 24-26, 27-28, 29, $30-32,33,36$

collective work 120,126

colonial 3-7, 19-20, 22-24, 26, 33-34, $38-39,45,51-57,59-60,66,68,81,83$

commercialization 55-57; see also agricultural: commercialization

Commission for Agricultural Costs and Prices (CACP) 165, 180n1

Conservator of Forests in Bengal 74 corruption 149

country boat $74-75,80$

crop: choice 203, 204, 207, 209, 211 , 214-15; diversification 11, 174-75, 178,180 
Crop Diversity Index 169-70

cropping: intensity $162,179,211$; pattern $66,92,96,113,119,164,169,178-79$, 208, 213, 219

customary right 24,72

cyclone 70,73

\section{darkhast 24-25}

Department of Minor Irrigation 109, 116

determinants of well investment 93, 97

development lease 72,74

diesel oil 1, 7, 10, 109, 138, 139-40, 147, 149-50, 152, 154, 156n10, 156n20, $157 \mathrm{n} 25,157 \mathrm{n} 31,163,201,227$

dittam 24

diversification $38,84,169$; crop 11 , 174-75, 178, 179, 180

diversity $38-39,45,48,51,51,59,121$, $161,167,169-70,174,180$

drainage system $110,117,118,119,126$

drip irrigation 153

dug well 138, 211, 212, 216-18, 220

Electricity Act 2003 144, 156n 13

electrification 10, 132, 134, 138, 151-52, 156n20, 201, 205, 221, 227, 233, 243

entitlement 3, 38-40, 43, 45, 48-55, 57, 59-60, 135

epidemics 73

evapotranspiration (PET) 203, 204, 206, 207, 209, 216, 217n11

famine $4,19,33,60,70,81$

feasible wells 93,105

fertilizer 102, 162-63, 166, 178-80, 190; chemical 2, 8, 11, 161, 172, 184;

consumption 189 ; price $185,187,188$, 197; subsidy $2,12,184-85,186,188$, 195, 198-200; use 163, 164, 167, 172, $176-77$

fiscal deficit 132, 141, 142, 143, 144, 152, 184,195

flat (electricity) tariff 1, 9-12, 14, 131, 132, 134-35, 151-53, 155n1, 155n3, 155n7, 157n24, 227-28, 230-36, 241-44, 245n5

food demand 185, 198

food-water-energy nexus 1-2, 7, 9-13, $131,134-35,138,149,151-53,184$

forest products $39-40,68,74-75,81,83$ fuel $75,81,83,149,186$ gantidar 78

Godavari 20

grain market $70,80-81,83$

Great Depression 33, 80

Green Revolution 7, 34-35, 136, 153, 160-61, 164-67, 170-71, 179, 205, 218,233

groundwater: depletion 1-2, 9, 11, 148-49, 152, 154, 171-72, 175, 180; markets 2, 11-12, 226-27, 231, 234, 240, 242-43; pollution 161, 190; quality 94; recharge 101, 104, 106, 119, 202, 218, 221, 232; table 156n16, 171, $172,205,216$

Guha, S. 33

Guha, R. 38-39

Gujarat 2, 10, 12, 105, 148-51, 153, 219, $227-33,240-44$

haoladar 76-79, 83-84

hard rock 97; aquifers 202; area 10-12, 147-49, 151, 219, 230; layers 213, 221

high yielding varieties (HYVs) 8, 154, 164, 179, 205

influenza 19, 35

intermediate tenure holder 77

investment $9,11,45,57,84,91,93,97$, 101, 105-07, 163, 176, 185, 201, 221

jajmani system 55

janglebari talukdar 72

Jyotigram scheme 219, 221, 227, 229-32, 240

kani 20

kudimarammat 34

land system 3, 20, 23, 33, 52

large-scale capitalist 77

layered society $76,79,83$

Ludhiana 203, 204, 205, 206, 208

Madras 19, 24, 26, 29, 81-83

Madras Presidency 20, 22, 25, 29, 35

Madurai 208, 209, 211, 213, 217

Mahatma Gandhi National Rural Employment Guarantee Act (MGNREGA) 107, 118, 126, 220, 221

Maximum Retention Price (MRP) 187-88 
metered (electricity) tariff 228, 230-31, 234-36, 241, 243-44

metering 134, 147-48, 151, 157n24, 228, 234-36, 242, 244; system 12, $151-52,155 \mathrm{n} 2$

migration $6,14 \mathrm{n} 12,26,63 \mathrm{n} 25,107,220$ minimum support prices (MSPs) 7, 165, 180n1, 207, 221

mirasi system 3, 19-20, 22, 24, 33-34, $36 \mathrm{n} 5,61 \mathrm{n} 1$

mirasidar 22-26, 29, 36n6, 36n9

monoculture 167, 174, 205, 218, 221

monsoon 2, 14n13, 45, 92, 94, 154, 203, 207-08, 232

Monsoon Asia 2

Morrellganj project 77

Mughal regime 72

natural oligopoly in water markets 227 , 243

Nepal Terai 10, 141, 147-49, 151-54

New Pricing Scheme (NPS) 186

nitrogen: cycle 184-85, 190, 191, 192,

194; efficiency 184-85, 195-96, 197;

fertilizer 12, 177, 184-88, 190, 192-95, 197, 199; flow model 185, 190, 191-92, 193-94, 195

NPK ratio 172, 195, 196

nutrient balance in soil 195

Nutrient Based Subsidy (NBS) 188

occupancy right $56,76,78$

organic farming $11,177-78$

Orissa (Odisha) 2-4, 38, 52, 56, 59-60,

$144,147,152,173$

P \& K fertilizer 184-88, 196-97

Pakistan 10, 14n10, 141, 148, 151, 155n2, $155 \mathrm{n} 4$

pangu $24-25$

partial tank desilting 100-02

patta 24-25

pattadars 24

payakari $24-25$

percolation 91; loss 206, 207, 216, 217, 222n5, 222n11; pond 103, 104-05, 107 , 151, 220-21; tank 101

Permanent Settlement 26, 27, 30, 68, 77-78

Persian wheel 4, 13, 155n8

plot-to-plot irrigation 113, 116, 125

ploughman (karsha) 79

political patronage 131
Ponneri 29

population projection 198-99

poverty alleviation 149,151

power: outage $1,9,131,207$; rationing

227, 229-30, 242, 244; shortage 1, 131;

subsidy $1-2,12,14 \mathrm{n} 11,131-32,135$,

$141,142,143,144-52,154,155 \mathrm{n} 3$,

156n14, 156n18, 157n23, 163, 167, 176,

$227,230,232,244$; theft $132,134,149$, $228,230,237,243$

protected forest $59,116,119-20$

pump irrigation economy 148, 232

pump-set 131-32, 134-35, 136, 138, 144, 146, 149-52, 205, 207, 209, 218, 222n2, $222 n 7$

Punjab (India) 2, 10-12, 14n14, 136, 145, 148, 150, 154, 156n14, 160-69, 170, 171-79, 195, 202-03, 205, 207, 209, 213, 216, 217-19, 221, 227

railway network 81

rainfall $2-4,11,20,21,38,45,48,50,88$, 89-90, 91, 93-93, 94, 96, 99, 101, 106, 109, 118, 149-50, 172, 179, 202-03, 204, 207-08, 209, 213, 217

raiyatwari $3,22-24,36 \mathrm{n} 6$

reclamation $2,10,23,26,66,68,70$, 72-81, 83-84

reserved forest $74-75$

Retention Price Scheme (RPS) 185

re-export of rice 83

rice-deficient district 80,84

rich peasant $66,78,83$

rich peasant-praja relation 83

risk 3, 38-39, 45, 49-50, 59-60, 91, 96,

175, 197; management 38, 45

salinity 148,172

Salinity Control and Reclamation Project (SCARP) 148

seasonal laborer (dawal) 76

security 4, 10, 22, 33, 39, 60, 160-61, 164, $168,173,180,197,244$

semi-arid 1-2, 9-10, 88, 149, 152, 201-02

share system 3, 20, 22, 24, 26, 43, 45,

46-47, 49-50, 53, 57, 60, 62n10

sharecropper 11, 75, 154, 228, 230, 232

sharing 38-39, 45, 49, 51, 59

soil health management 11, 176-77, 180

solar (irrigation) pump 105-06, 151, 153-54, 219

standard water requirement 207, 217 
State Electricity Boards (SEBs) 1, 9, 131-32, 134, 142, 144-45, 149, 152, 155n5, 202, 219

State Electricity Regulatory Commission (SERC) 144, 152

sub-infeudation 77,79

Sundarban talukdar 77-78

Sundarban tenure system 83

Sundarbans Commissioner 72

sustainability $1-4,7,11-12,38,43,45$, $48,53,103,161,163,167,171-72$, $174,178-79,184,201-02,205,218-19$, 221,227

swatantram $24,36 \mathrm{n} 9$

Tamil Nadu 2-4, 6, 10-12, 14n13, 20, 29, 88, 89-90, 102, 104, 106, 135, 145, 150-51, 155n7, 156n18, 157n26, 198, 202, 207-10, 211-12, 217-19, 221, 227, $245 \mathrm{n} 10$

Tanjavur 20

tax 25-26, 43, 45, 46, 50-56, 62n10, $74-75,101$

temporarily settled area 68,70

tenants-at-will 78, 83

tidal wave $68,70,73$

time-of-the-day electricity pricing 243

total fertility rate (TFR) 35, 198, 199

transmission and distribution (T\&D) losses 131

transportation system 68

Trichinopoly 22

tube well 1, 10, 12, 109, 110, 121, 138, 139-41, 148, 154, 155n6, 156n10, 157n24, 157n29, 163, 170-71, 175, 203, 205, 206, 207, 222n2, 226-36, 242-44, 244n2, 245n5, 245n7, 245n11; dieseloperated 10, 154, 156n10, 163

unbundling 142, 144, 152

under-raiyat (charcha raiyat) 78 , 83-84

varietal diversity index 170

vatan $3,20,61 \mathrm{n} 1$

village panchayat 116, 118, 126

water conservation 175, 179, 219

water extraction mechanism (WEM) 147, 149, 226-27, 233, 235, 239, 242-44

water seller 150, 157n25, 226-27, 230-32, 234-35, 238, 240, 242-44

water shortage 110,120

well irrigation 2, 4-7, 11, 33-34, 35, 93, 102, 119, 202, 205, 208-09, 216, 217-18, 220-21, 233-34

West Bengal 2, 10, 12, 14n12, 148, 150, $152,154,155 \mathrm{n} 6,156 \mathrm{n} 19,157 \mathrm{n} 24$, 157n29, 157n31, 173, 227, 233-37, 239, 240, 242-45

World Population Prospect (WPP) 198-99

World War I 33

World War II 209

zamindari 27, 30, 109, 113, 118 


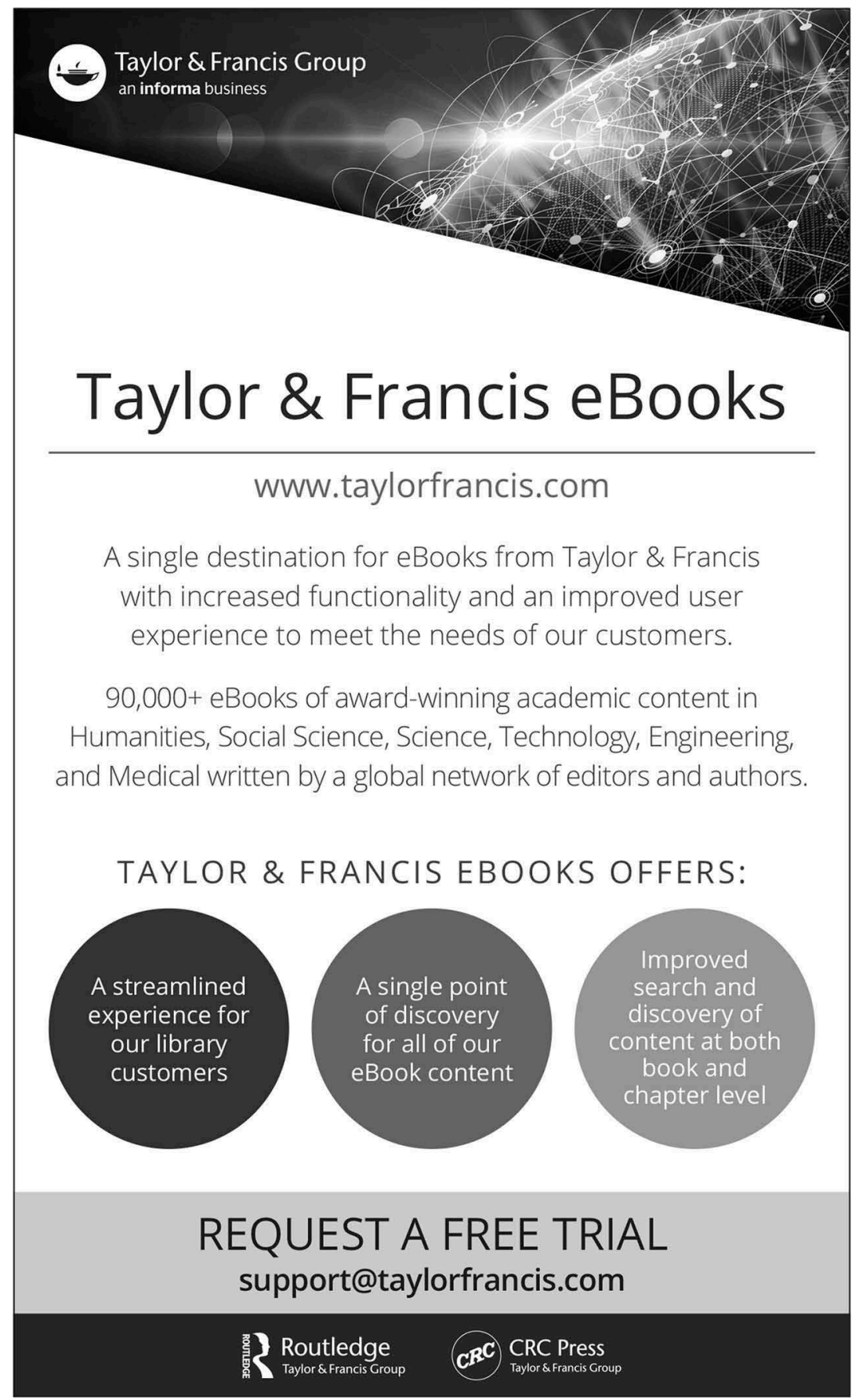

